UNIVERSIDADE DE SÃO PAULO

FACULDADE DE FILOSOFIA, LETRAS E CIÊNCIAS HUMANAS

DEPARTAMENTO DE GEOGRAFIA

PROGRAMA DE PÓS-GRADUAÇÃO EM GEOGRAFIA HUMANA

CAIO LOURENCINI CAVELLANI

DELIMITAÇÃO TERRITORIAL DE MUNICÍPIOS - PROPOSTA METODOLÓGICA

São Paulo

2015 


\author{
UNIVERSIDADE DE SÃO PAULO \\ FACULDADE DE FILOSOFIA, LETRAS E CIÊNCIAS HUMANAS \\ DEPARTAMENTO DE GEOGRAFIA \\ PROGRAMA DE PÓS-GRADUAÇÃO EM GEOGRAFIA HUMANA
}

DELIMITAÇÃO TERRITORIAL DE MUNICÍPIOS - PROPOSTA METODOLÓGICA

Caio Lourencini Cavellani

Dissertação apresentada ao Programa de PósGraduação em Geografia Humana do Departamento de Geografia da Faculdade de Filosofia, Letras e Ciências Humanas, da Universidade de São Paulo, para a obtenção do título de Mestre em Geografia Humana.

Orientador: Prof. Dr. Reinaldo Paul Pérez Machado

São Paulo

2015 


\section{AGRADECIMENTOS}

Agradeço, em primeiro lugar, a minha família. Aos meus pais, Antonio Celso e Maria de Lourdes, as melhores referências de caráter, humildade, perseverança e superação que um filho poderia ter. À minha irmã, Camila, por todo o apoio e incentivo que recebi ao longo de todos estes anos. À meus avós, tios, primos e demais familiares, os quais contribuíram, e muito, para minha formação enquanto ser humano.

Ao professor Reinaldo Paul Pérez Machado, orientador assíduo, paciente e comprometido com o desenvolvimento deste trabalho desde o seu esboço inicial.

Aos professores Jorge Gustavo da Graça Raffo (in memorian) e Sandro Francisco Detoni, membros da banca examinadora do primeiro estágio de construção deste trabalho, apresentado enquanto trabalho de graduação individual.

Aos professores Alfredo Pereira de Queiroz Filho e André Roberto Martin, membros da banca de qualificação e notáveis contribuintes para um direcionamento mais equilibrado e consistente desta dissertação.

A todos os colegas e amigos feitos ao longo dos cursos de graduação e pósgraduação no Departamento de Geografia da Faculdade de Filosofia, Letras e Ciências Humanas da Universidade de São Paulo, os quais, de alguma forma, contribuíram tanto para a minha formação como geógrafo como para o meu amadurecimento enquanto indivíduo.

Ao Instituto Geográfico e Cartográfico do Estado de São Paulo (IGC), na figura de cada um de seus funcionários. Primeiramente pela oportunidade cedida para o início de minha atuação profissional. Em um segundo momento, pelo inestimável apoio para a construção desta pesquisa, seja através das informações cedidas, seja através dos conselhos dados ao longo dos dois anos que por lá estive diariamente.

Dedico este trabalho especialmente à minha esposa Ana Júlia, amada companheira de todas as horas, incentivadora em todos os momentos desta longa e prazerosa caminhada geográfica. 


\section{RESUMO}

O presente trabalho tem, como objetivo principal, apresentar uma proposta metodológica para a delimitação territorial de municípios.

A questão fronteiriça, aparentemente irrelevante em um mundo cada vez mais integrado, classificado por muitos como um "mundo sem fronteiras", mostra-se, na verdade, cada vez mais presente, dentro de uma fragmentação permanente do espaço geográfico em diversas unidades políticas. Dentro disto, os limites territoriais internos, primordialmente os de caráter municipal, apresentam grande importância na vida cotidiana de todos os indivíduos. São estas linhas que determinam a localização de eleitores, a implantação de escolas, atendimentos em postos de saúde, entregas de correspondências, implantação de linhas telefônicas, cadastramentos pra fins escolares, recolhimento de lixo, pesquisa para censos demográficos, abastecimento de água e luz, melhoramentos em vias de acesso, entre outros. Dada tamanha importância, espera-se que os mesmos tenham suas definições baseadas em critérios concretos e coerentes.

A análise dos limites municipais brasileiros demonstra, entretanto, uma situação distante da ideal. Enquanto parâmetros populacionais, econômicos e eleitorais são discutidos como requisitos mínimos para a criação de municípios, elementos territoriais acabam sendo relegados. O evidente contraste entre territórios demasiadamente extensos ao lado de pequenas áreas municipais em conjunto com formas das mais variadas possíveis, permite afirmar que, em meio a total permissibilidade de atuação técnica e política, não há critérios consistentes estabelecidos para a definição das linhas limítrofes.

Dentre os inúmeros problemas gerados pelas delimitações inconsistentes, destaca-se a questão da posição do limite em relação às sedes municipais dos municípios confrontantes. O posicionamento "desequilibrado" da referida linha pode gerar situações em que determinada população, apesar de residir oficialmente em um município, usufrui dos serviços públicos de outro. Nestes casos, podemos considerar duas áreas territoriais municipais distintas - a jurídica, definida por lei, e a real, efetivada na realidade.

Neste contexto, propõe-se a consideração da distância como elemento central para a análise territorial. Levando em consideração que um indivíduo, localizado entre duas sedes municipais, ao necessitar de algum serviço público oferecido em ambas, tende a se deslocar para a mais próxima e, que o referido deslocamento se dá primordialmente através das vias de acesso (rodovias, estradas, caminhos, etc.), conclui-se que a adoção da simples distância euclidiana não é satisfatória, devendo ser substituída pela distância viária, primordialmente medida pelo tempo de viagem. Desta forma, eis a premissa da pesquisa: o território municipal deve corresponder a sua respectiva área de influência, definida pelo conjunto dos pontos mais próximos (considerando o menor tempo de viagem necessário) de sua sede em relação às sedes do entorno.

Palavras Chave: Fronteiras, Delimitação Territorial, Áreas de Influência. 


\section{ABSTRACT}

This work has as main objective to present a methodology for territorial delimitation of municipalities.

The border issue, apparently irrelevant in an increasingly integrated world, rated by many as a "borderless world", it is shown, in fact, increasingly present, in a permanent fragmentation of geographic space in various political units. Within this, the internal boundaries, primarily the municipal boundaries, have major importance in everyday life of all individuals. These are lines that determine the location of voters, the deployment of schools, attendance at public health clinics, delivery of correspondence, implementation of telephone lines, registrations for school purposes, garbage collection, search for demographic censuses, supply water and light, improvements in access roads, among others. Given such importance, it is expected that they have their settings based on specific and consistent criteria.

The analysis of the Brazilian municipal boundaries demonstrates, however, a distant ideal situation. While population, economic and electoral parameters are discussed as minimum requirements for the creation of municipalities, territorial elements end up being relegated. The stark contrast between too extensive territories side of small municipal areas together with the most diverse forms, have shown that, amid all permissibility of technical expertise and policy, there is no consistent criteria for defining the boundary line.

Among the numerous problems caused by inconsistent boundaries, there is the issue of position limits in relation to the municipal headquarters of the bordering municipalities. The "unbalanced" position of that line can lead to situations where certain population, although living officially in municipality, enjoys the public services of another. In these cases, we can consider two different municipal territorial areas - legal, defined by law, and the real, effective in reality.

In this context, it is proposed to consider the distance as a central element for territorial analysis. Assuming an individual, located between two municipal centers, to require some public service offered in both, tends to move to the closest and that displacement occurs primarily through the access roads (highways, streets, paths, etc.), it is concluded that the adoption of simple Euclidean distance is not satisfactory and should be replaced by the road distance, primarily measured by travel time. Thus, this is the premise of the research: the municipality must correspond to their respective area of influence defined by the set of closest points (considering the lowest travel time required) from its headquarters in relation to the surrounding headquarters.

Keywords: Borders, Territorial Delimitation, Areas of Influence. 


\section{SUMÁRIO}

Apresentação

1. A relevância das fronteiras no mundo contemporâneo 7

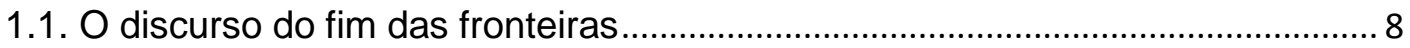

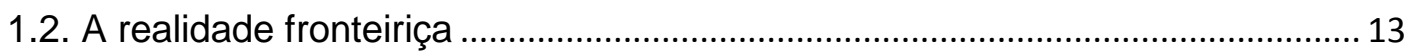

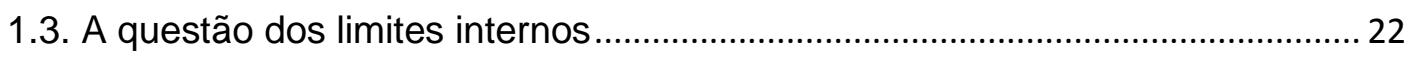

1.4. Limites internos e a distribuição de recursos .................................................... 38

2. Análise da delimitação territorial de municípios no Brasil - legislação e

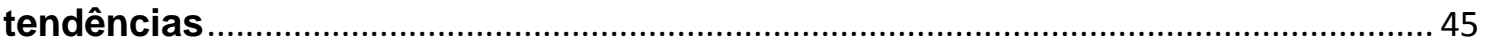

2.1. Aspectos legais - breve histórico .................................................................. 45

2.2. Acidentes naturais e linhas geodésicas ............................................................ 61

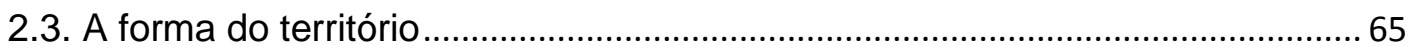

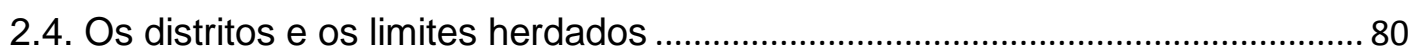

3. Circulação: um parâmetro possível para a delimitação territorial de

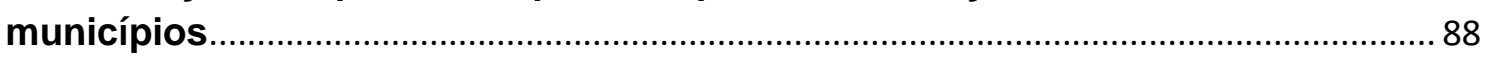

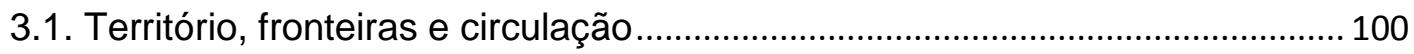

3.2. Lei do mínimo esforço, eficiência espacial e o fator tempo .............................. 113

3.3. Da alocação à delimitação - proposição de adaptação sobre uma malha regular 


\section{APRESENTACÃO}

A forma mais prática e simples de iniciar a apresentação deste trabalho é através da colocação de duas perguntas para quem o lê. A primeira: Quais os limites do território do seu município? Em um primeiro momento, pode haver algum tipo de desconhecimento ou dúvida, porém, é possível que um número relevante de pessoas consiga identificar $O$ rio $X$, a rua $Y$ ou a serra $Z$ como 0 elemento físico que caracterize o fim de um território municipal e o início de outro. De forma geral, ao longo do tempo vamos consolidando este tipo de conhecimento. A viagem por uma determinada rodovia com certa frequência, por exemplo, pode tornar familiar a identificação de possíveis placas de sinalização de limites municipais. A associação das mesmas com o atravessamento de uma ponte possivelmente acarreta no estabelecimento de uma relação, mesmo que nem sempre, entre o limite do território e o rio sobre o qual se está passando. Em suma, pode-se afirmar que o conhecimento e identificação das bordas do município de origem ou de moradia é algo cotidiano, comum a grande parcela da população.

O segundo questionamento é mais complexo: Porque a linha limítrofe passa por aquele local? Porque não por outro? Aqui, a quantidade de pessoas que possam proferir algum tipo de explicação consistente e plausível deve ser mínima, para não dizer nula. Conhecemos o local, mas não questionamos os motivos ou as causas que o produziram enquanto elemento de separação entre unidades político-administrativas. É possível que alguém aponte uma determinada lei como a causa, o que, entretanto, não resolve o problema. O texto jurídico pode instituir o limite, mas não o justifica, à medida que não apresenta qualquer explicação do processo que levou a elaboração daquela descrição. Com isso, essa não seria uma resposta aceitável.

Pode-se imaginar uma resposta como "porque era o limite quando o atual município era distrito de outro". Novamente a pergunta não encontra resposta. A elevação de um distrito a condição de município, na grande maioria das vezes, ocorre com a manutenção das divisas distritais, agora municipais. Isto é um fato. Entretanto, apesar de identificar o processo histórico, não seria uma justificativa da 
delimitação. Neste caso, porque os limites do distrito eram aqueles? Volta-se assim à estaca zero.

É justamente dentro deste panorama inicialmente sem respostas que residem as motivações desta pesquisa. Nesta, se intentássemos adotar um caso específico de análise, nada mais estaríamos realizando do que a busca por uma resposta local, certamente inválida para a solução geral do problema. Desta forma, ao invés de tentar responder o porquê do rio Tietê ser adotado enquanto limite entre os municípios de São Paulo e Guarulhos em determinado trecho, por exemplo, o foco deste trabalho está na tentativa de identificação de parâmetros técnicos coerentes e consistentes para a delimitação territorial dos municípios brasileiros. Aliado a isto, buscar-se-á apresentar uma proposta metodológica para a determinação das referidas linhas limítrofes.

Neste contexto, têm-se dois elementos que justificam e qualificam o trabalho proposto: a relevância da temática no cotidiano da sociedade como um todo e a escassez de trabalhos correlatos.

De uma forma ou outra, direta ou indiretamente, estamos todos atrelados aos territórios intranacionais, aos seus limites e consequentemente a todo o aparato político e jurídico particular de cada um. São estas linhas limítrofes, comumente negligenciadas, que definem os impostos a serem pagos, leis a serem cumpridas, os serviços básicos oferecidos, etc.

Em contrapartida, a análise da produção acadêmica ligada ao tema aponta para um cenário distinto. Em um primeiro momento, dentro da consideração das discussões teóricas provenientes primordialmente da Geografia Política - área da Geografia na qual tradicionalmente estiveram alocadas as fronteiras - nota-se a predominância dos limites internacionais em detrimento dos limites internos, alvos de poucos trabalhos, comumente direcionados a analise de casos específicos.

Além disso, discussões acerca de procedimentos metodológicos para processos de delimitação territorial são ainda mais raras - para não dizer nulas. Partindo de uma situação possível, dentro da qual deverão ser estabelecidos os limites territoriais de um novo município, qual a metodologia que deve - ou pode - 
ser adotada? Quais os parâmetros a serem considerados? Quais os dados efetivamente importantes? Temos aqui uma lacuna.

Em suma, a proposta que se pretende apresentar busca, mesmo que de forma incipiente, preencher este vazio metodológico, intentando contribuir para a atuação de geógrafos - e demais profissionais - responsáveis pela definição das bordas municipais, tanto no âmbito teórico como no prático. Eis a justificativa da pesquisa.

No que tange a estrutura, dentre as inúmeras possibilidades imaginadas, optou-se pela adoção de três eixos principais, cada qual desenvolvido em um conjunto de capítulos específicos. O primeiro deles está centrado na própria questão das fronteiras/limites/divisas, mais precisamente na discussão de sua relevância no mundo atual. Haveria sentido estudá-las nos dias atuais? De um lado, em um cenário tão difundido de globalização, muitos discursos apontam para o "fim" dos limites políticos, os quais não apresentariam qualquer significado positivo atualmente, uma vez que atravancariam a circulação de bens e de capitais. Esta análise, puramente econômica, por sua vez, contrasta com a opinião de outro grupo de autores, "defensores" da permanência dos limites. As linhas limítrofes não estariam perdendo importância, mas apresentando modificações em algumas de suas funções clássicas. Ao mesmo tempo em que a função fiscal veio abaixo em muitos países a partir do início dos anos 90, a função legal nunca deixou de existir, pelo contrário, novas divisões políticas-territoriais acabaram surgindo de lá para cá.

Ademais, ao orientar a referida proposta para a análise das bordas intermunicipais, de caráter interno aos países, faz-se necessário a inserção de uma análise especifica referente a este tipo de limite, direcionada a identificação de seu efetivo papel no cotidiano da população em geral. O limite municipal, não apresentando qualquer tipo de impedimento ao deslocamento de pessoas e bens, teria algum papel considerável na vida das pessoas? Em um primeiro momento, assim como já presenciado pelo autor no próprio meio acadêmico da Geografia, pode-se imaginar que não. "É apenas uma linha" diriam muitos daqueles confrontados com a questão. A realidade, entretanto, apresenta elementos divergentes da simples negativa, tanto no que tange a esfera das pessoas quanto a estatal. O limite define um território dentro do qual a autoridade municipal é 
estabelecida, ou seja, define a área de atuação de um poder político, instituído de um dever de oferecimento de serviços básicos (que ao mesmo estão atribuídos) para a população residente naquela porção do espaço. De certo, moradores do centro da cidade (sede municipal) podem não ter problemas de acesso a um posto de saúde ou para matricular os filhos em alguma escola municipal. Mas e aqueles que residem nas áreas limítrofes? Para estes, duas situações podem ser comumente encontradas: se a área apresentar algum valor para as prefeituras envolvidas (existência de uma fábrica ou de uma jazida mineral, por exemplo), possivelmente haverá uma "briga política" entre as mesmas, ocasionando uma situação de indefinição em que o morador ou deixa de ser atendido, ou é taxado duplamente por ambas. Se na área não existir qualquer interesse econômico, não é difícil que um jogo de "empurra-empurra" aconteça, afinal, as pessoas representariam, dentro da mentalidade empresarial de inúmeras prefeituras, gastos não compensados pela arrecadação conseguida pela cobrança dos impostos municipais na área. $\mathrm{Na}$ alçada estatal, é justamente na questão da arrecadação que o limite surge como elemento crucial para a administração municipal. Com a Constituição de 1988, o município, além de conquistar grande autonomia em comparação com o período do regime militar, também passou a ser responsável pela prestação de inúmeros serviços básicos (na saúde e na educação principalmente). Como o aumento da responsabilidade não foi acompanhado de uma elevação proporcional do repasse de impostos criou-se assim uma situação problemática, tanto na falta de recursos como na disputa pelos mesmos. Dentro disto, considerando um panorama de fundos escassos e de preponderação dos repasses federais e estaduais na receita municipal perante a arrecadação interna, os limites territoriais, praticamente despercebidos, "atuam" de maneira crucial. Se a distribuição de impostos obedece a critérios como população, área territorial, área agrícola, área alagada, área de proteção ambiental, etc., as mesmas proveem de dados coletados e gerados em órgãos oficiais, os quais, por sua vez, utilizam-se do território municipal como molde para suas análises. A população de um município é constituída pelo total de pessoas que residem na área territorial do mesmo; a área cultivada, como aquela em que é praticada a agricultura dentro dos limites do território; a área de proteção ambiental, como a soma das áreas das unidades de proteção/conservação localizadas no interior de cada município. Chega-se então a 
uma simples relação: a adoção de uma linha limítrofe inconsistente com a realidade acarreta em dados e estatísticas oficiais problemáticas, o que, por sua vez, ocasiona o repasse incoerente de impostos.

Partindo deste contexto, passe-se a refletir então sobre o panorama atual da delimitação territorial de municípios no Brasil. Existem, de fato, parâmetros ou metodologias para este procedimento no país? São estes os questionamentos da segunda parte. A partir de um levantamento prévio dos dispositivos legais que definiriam e definem as regras para divisão territorial em municípios, pretende-se, além de explicitar os principais critérios identificáveis, analisar qualitativamente alguns deles com o intuito de mensurar a sua real efetividade, de modo que se possa responder a questão inicial, bem como analisar e questionar os problemas potencialmente existentes e identificados.

Confirmando-se a hipótese inicial, de não existência de qualquer tipo de padrão consistente, torna-se necessária, a partir da terceira parte, a apresentação de um critério, simples e de fácil compreensão, para utilização nos processos de delimitação territorial de municípios. Em meio às possibilidades existentes (população, por exemplo), a questão da circulação surge como um fator coerente, uma vez que a relação da mesma com o território é intrínseca, sendo discutida em inúmeros trabalhos clássicos da própria Geografia. Se pensarmos o município enquanto uma área de influência de uma sede municipal, qual seria a forma de integração entre seu centro e sua área territorial? Como uma pessoa, residente na zona rural, estabelece relação com a cidade? Parece-nos claro o papel das vias de circulação para o esclarecimento destas questões. De qualquer forma, o simples apontamento da circulação enquanto parâmetro ainda apresenta certa generalidade, passível de especificação. Admitindo que um cidadão apresente tendência de deslocamento pautada pela proximidade, ou seja, pela busca do menor caminho para a sua locomoção até determinado ponto, chega-se a duas situações distintas: o caminho mais curto ou o caminho mais rápido? Considerando que o tempo gasto é preponderante sobre a distância medida em metros/quilômetros no momento da escolha de um caminho a ser feito, optar-se-á pela segunda. Assim sendo, intentando facilitar o acesso da população a serviços básicos e a própria oferta dos mesmos pela administração municipal, acredita-se, e se propõe, que o limite 
territorial deve estar localizado o mais próximo possível dos pontos em que o tempo de deslocamento para cada sede municipal envolvida seja equivalente.

Como forma de apresentação e argumentação deste raciocínio será utilizado um modelo hipotético, constituído por uma área aleatória dentro da qual estão localizadas quatro cidades e um núcleo de povoamento rural. A subsequente necessidade de estabelecimento de limites entre os municípios correspondentes a cada uma das sedes, com a respectiva alocação do núcleo em um dos quatro territórios, será o ponto de partida para toda a construção metodológica pretendida. 


\section{A RELEVÂNCIA DAS FRONTEIRAS NO MUNDO CONTEMPORÂNEO}

Os acontecimentos mundiais ocorridos entre o fim da década de 80 e o início da de 90 do século passado apresentaram grande influência no cenário fronteiriço mundial. A partir deste momento teve início um processo de profunda discussão e análise crítica do conceito de fronteira, resultado direto da intensificação do fenômeno da globalização com o fim da Guerra Fria e de suas transformações territoriais correlatas (BRADSHAW E GÓMEZ, 1999).

Em um primeiro momento, a partir do discurso globalista, desenvolveu-se a ideia de que o mundo caminhava para um cenário de abolição das fronteiras entre os diferentes Estados-Nação. Com os fluxos de pessoas, mercadorias e informações cada vez mais intensos, surge então o questionamento da real função e efetividade das linhas de delimitação dos territórios nacionais. Neste sentido, termos como "relíquias do passado" e "ilusões cartográficas" seriam atrelados às feições fronteiriças.

Entretanto, análises mais realistas e menos idealistas de um mundo integrado, revelaram que as fronteiras não deixaram de existir, pelo contrário, foram multiplicadas em número e extensão. O fim da antiga União Soviética, por exemplo, produziria, logo no início da década de 1990, quinze novos Estados independentes e, consequentemente, novas fronteiras políticas no cenário mundial. Além disso, outras inúmeras linhas fronteiriças seriam objetos de acordo, envolvendo desde elementos de delimitação até a revisão ou efetivação dos processos de demarcação.

A questão fronteiriça passa então por uma revisão de análise. As mudanças políticas e econômicas, associadas aos avanços das comunicações, efetivamente influenciaram e modificaram os paradigmas históricos das fronteiras. A percepção de que estas linhas podem estar ligadas a processos de integração e não mais apenas de separação, todavia, não as invalidam como tal. Mesmo em casos como o da União Europeia, onde antigas barreiras fiscais e de circulação foram removidas, o mapa político continua apresentando as fronteiras entre os países membros, pois, de fato, elas continuam existindo. 


\subsection{O DISCURSO DO FIM DAS FRONTEIRAS}

De acordo com Yeung (1998), a globalização das atividades econômicas e o crescimento das corporações transnacionais deram origem a ideia de um mundo sem fronteiras, dentro do qual o Estado não mais teria capacidade de exercer algum tipo de influência sobre o capital transnacional, de circulação livre e global, elemento de uma economia mundial cada vez mais integrada e interdependente.

Dentro disto, Newman (1999) aponta para a ocorrência de uma transição das linhas fronteiriças, em um processo de permeabilização da antiga noção e função primordial de separação e barreira. Em um mundo tomado pelos satélites e pela internet, dotado de fluxos cada vez mais intensos de pessoas, informações e capitais, as fronteiras nada mais seriam do que "relíquias do passado". Além disso, a grande quantidade de entradas e saídas, tanto de pessoas como de mercadorias, existentes na atualidade, acusaria a falha geral das fronteiras enquanto elemento determinante na manutenção para fora do território daquilo que não seria desejável. Dentro deste panorama de integração mundial, temas como "cooperação transfronteiriça", "regiões transnacionais" e "regiões de fronteira" (ligando os dois lados do limite territorial) estariam ganhando cada vez mais espaço.

As questões da desterritorialização e do aumento da permeabilidade fronteiriça também seriam analisadas por Bradshaw e Gómez (1999). Para os mesmos, os processos de cooperação transfronteiriços e de integração regional, frutos da globalização, estariam causando a perda paulatina da importância das fronteiras, o que poderia apontar para uma tendência de surgimento de um mundo sem as mesmas.

Moraczewska (2010), ao analisar as mudanças no panorama mundial a partir do prisma das relações internacionais, aponta para a ocorrência de paradigmas distintos de análise da questão estatal, territorial e fronteiriça. O chamado paradigma transnacional seria caracterizado primordialmente pelo reconhecimento da continuidade das fronteiras, entretanto, agora não mais como barreiras, mas como pontes de ligação entre as diversas nações e economias. Dentro disto, os limites entre os diferentes Estados apresentariam uma diminuição de sua importância mediante a abolição de antigas estruturas de bloqueio dos fluxos de bens, pessoas, 
dinheiro e informação. A radicalização deste pensamento seria encontrada no paradigma global, "defensor" do fim real das fronteiras, as quais não apresentariam qualquer tipo de relevância no mundo atual. Em suma, estas seriam apenas linhas virtuais representadas em mapas e que não se efetivariam como tal na realidade.

Segundo Cesar e Albuquerque (2012), esta visão globalista, fruto do triunfo da ideologia liberal-democrática, produziria grande repercussão e aceitação no ambiente das ciências sociais em torno do processo de globalização e da crítica às fronteiras políticas. Em meio aos inúmeros autores, o japonês Kenichi Ohmae, defensor do "fim do Estado-Nação" a partir da perda de autonomia das unidades políticas no interior da universalização dos mecanismos de livre-mercado, alcançaria significativa popularidade com suas obras. De acordo com este, o "mundo sem fronteiras" apresentaria alguns elementos e tendências características (OHMAE apud YEUNG, 1998):

1. Os investimentos deixam de ser geograficamente limitados, de modo que o capital passa a fluir para os locais que geram o maior retorno ou as melhores oportunidades;

2. A orientação da indústria é muito mais global nos dias de hoje. O Estado perdeu o controle sobre os fluxos de capital devido à ineficiência das regulamentações e dos incentivos em um cenário de fácil transposição das fronteiras nacionais;

3. A revolução nas tecnologias de transporte e informação permite a operação de corporações globais em praticamente todo o mundo;

4. Os indivíduos (enquanto consumidores) apresentam, cada vez mais, orientações e gostos globais.

A economia global não teria mais espaço para intervenções estatais, as quais deveriam se restringir apenas as ações de proteção do ambiente, educação da força de trabalho e construção de infraestrutura social segura e confortável. A homogeneização do mundo resultaria no fim das ideologias nacionais, prejudiciais sobretudo ao povo, o qual estaria sendo constantemente privado de mercadorias melhores e mais baratas devido ao atendimento de interesses de grupos específicos por parte dos governos dos Estados (OHMAE, 1991). 
Neste sentido, seria necessária então a substituição da atual ordem mundial baseada em Estados-Nação delimitados e independentes. As verdadeiras fronteiras do mundo ocorreriam entre as os chamados "Estados-Região", definidos não mais pelas fronteiras políticas, mas pelo tamanho e escala corretos para serem unidades de negócio da economia global - Vale do Silício, San Diego/Tijuana e Hong Kong/Sul da China por exemplo. Desta forma, em um panorama econômico sem fronteiras, qualquer tipo de representação cartográfica baseada nas nações nada mais seria do que uma mera ilusão (OHMAE, 1996).

...o Estado-Nação é cada vez mais uma ficção nostálgica. Por exemplo, faz ainda menos sentido atualmente do que anos atrás falar da Itália, da Rússia ou da China como unidades econômicas individuais. Cada um desses países é uma combinação heterogênea de territórios com necessidades totalmente diferentes e capacidades de contribuição totalmente diferentes. (OHMAE, 1996)

Para Ohmae (1996), a chegada do século XXI apresenta um fluxo cada vez mais intenso dos quatro "Is" - indústria, investimento, indivíduos e informação - os quais se efetivam sem impedimentos de fronteiras nacionais, derrubando assim os antigos modelos de países fechados e "protegidos" por suas linhas fronteiriças. Para o mesmo, a exposição das geografias locais à lógica global da economia levaria, certamente, às mesmas, níveis de prosperidade consideráveis. Além disso, no mundo competitivo atual, o Estado-Nação, agora privado de suas fontes de recursos aparentemente inesgotáveis como antigamente, seria obrigado a procurar auxílio na economia global, implementando mudanças domésticas como forma de atração do capitais. Por este processo passaria o afrouxamento e a "queda" das fronteiras, as quais, por sua vez, estariam apresentando uma dificuldade cada vez maior para sua concreta identificação.

Para muitos observadores, essa erosão dos elementos constitutivos do mundo político há muito tempo familiares tem sido uma fonte ao menos de desconforto e, bem mais provavelmente, de verdadeiro mal-estar. Eles costumavam saber com certeza por onde passavam as linhas fronteiriças: este é o nosso povo; aquele não é. Estes são os nossos interesses; aqueles não são. Estas são as nossas indústrias; aquelas não são. Não importava que poucas atividades econômicas permanecessem verdadeiramente domésticas em qualquer sentido compreensível por Adam Smith ou por 
David Ricardo. Tampouco importava que as pessoas servidas ou os interesses protegidos representassem uma fração pequena e declinante do complexo universo social de cada conjunto de fronteiras políticas estabelecidas. (OHMAE, 1996)

Por fim, ao dialogar com a tese do "fim da história" de Francis Fukuyama apresentada no início dos anos 90 - Ohmae (1996) aponta para o distanciamento da mesma em relação à verdade. De acordo com o mesmo, o mundo atual estaria apresentando um número cada vez maior de pessoas reivindicando o seu lugar na história, buscando uma vida melhor para si e para seus filhos e apresentando exigências de ordem econômica.

Acompanhe as manchetes dos jornais: as pessoas de todo o mundo, às vezes colocando-se em situação de risco pessoal, estão deixando claro que querem participar da economia global. Querem encontrar expressões para seus gostos e preferências. O que não querem é um governo central que Ihes diga que tipos de escolhas devem fazer em áreas pessoais de suas vidas. Economicamente, o que eles e todos nós buscamos é uma vida boa, em harmonia com nossos próprios valores, moldados pela escolha individual. O papel do governo não é fazer estas escolhas, mas assegurálas ao povo. Nenhum sistema consegue proporcionar uma vida boa para o seu povo se não for sensível a ele, se não se desenvolver a partir do fato irredutível do pluralismo. E é neste fato que se fundamenta a economia interligada. (OHMAE, 1991) 


\section{Regree Antlges:}

\begin{tabular}{ll}
\hline & Era Industrial \\
Epoca & Seculos XIX-XX \\
Descriçăo & - Impulsionada pelos governos dos Estados-naçöes \\
& - Soberania nacional \\
& - Forte controle por forças centralizadas \\
& - Sensivel as fronteiras \\
- Favorece o capital nacional e protege as empresas nacionais
\end{tabular}

- Visa à prosperidade no Estado individual através do crescimento econômico baseado na indústria e nas exportaçŏes

- Iniciacivas do governo

- Bom governo fortalece os setores industriajs prioritarios

- Mudanģa ocorre gradualmente com o passar das décadas

\section{Noves Rograe}

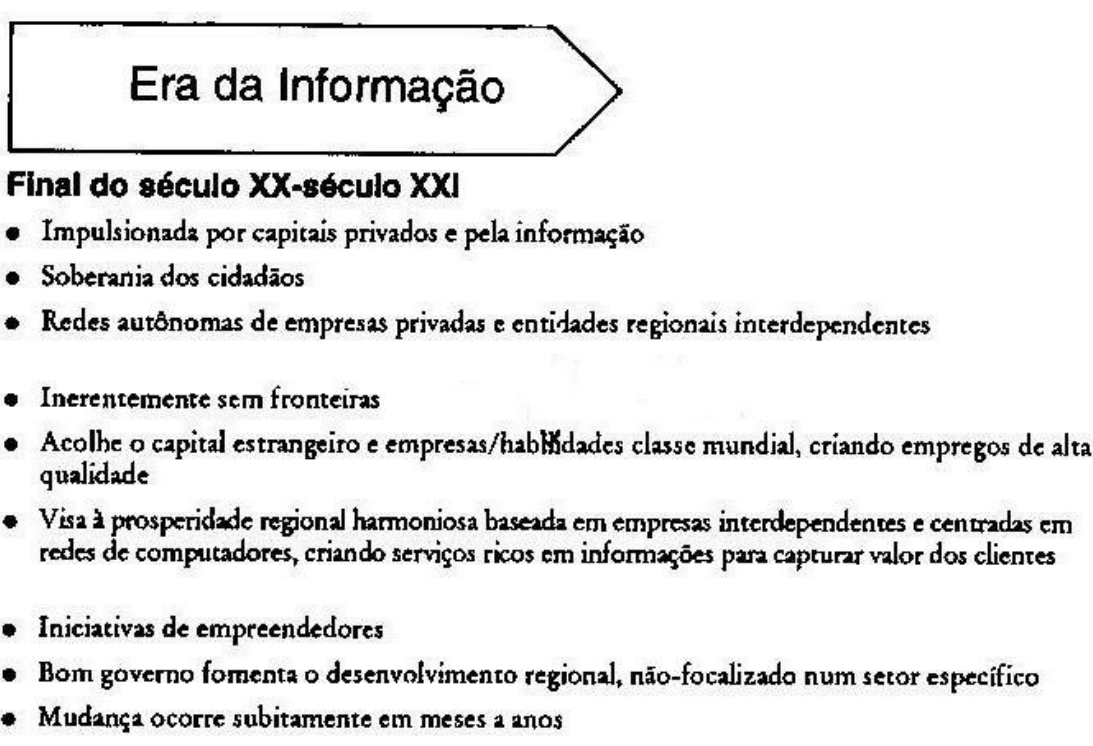

Figura 1.1-1 - Mudanças na unidade operacional na passagem da Era Industrial para a Era da Informação. Fonte: Adaptado de Ohmae (1996) 


\title{
1.2. A REALIDADE FRONTEIRIÇA
}

Segundo Raffestin (1993), diariamente, em todas as fases de nossa existência, somos confrontados com a noção de limite: traçamos limites ou esbarramos em limites. Qualquer relação entre os seres vivos estaria fundamentada no traçado de limites ou no choque com os mesmos. Dentro disto, o mesmo afirma que o surgimento do homem e a sua evolução histórica sempre esteve ligada ao desenvolvimento e as variações das noções de limites e fronteiras, os quais nunca desapareceram.

\begin{abstract}
Sem dúvida, o limite ou a fronteira não passam de um fenômeno banal e é por isso que não tem sido objeto de um grande interesse. Mas na realidade, eles nada tem de banal quando retomados na qualidade de sistema sémico no projeto social. Constituem uma informação lato sensu indispensável a qualquer ação. Portanto, cada vez é preciso estudá-los como portadores de uma informação que consome energia, para ser criada, controlada e mantida. Participam de todo projeto sociopolítico ou socieconômico e é por intermédio desses projetos que é conveniente situá-los. Constituem uma dimensão que nunca está ausente, pois não concernem somente ao invólucro espaço-temporal, isto é, toda classificação é estruturada por limites. Nesse caso, o termo "classificação" debe ser tomado no seu sentido mais genérico, no sentido de partição de qualquer conjunto. Sem partições o poder não tem nenhuma referência, nenhuma estrutura, pois não saberia mais como se exercer. Na famosa fórmula "dividir para reinar", encontra-se essa preocupação. O exercício de poder implica a manipulação constante da posição continuidade versus descontinuidade. $O$ jogo estrutural do poder conduz a assegurar ora a continuidade, deslocando limites, ora a provocar a descontinuidade, criando novos limites. Não é excessivo pretender que o poder, para se manter ou se reorganizar, tem necessidade de se apoiar sobre ese jogo geométrico dos limites. É um jogo paradoxal e permanente. (RAFFESTIN, 1993)
\end{abstract}

Goycochêa (1943), em pensamento semelhante, afirma que a primeira divisa riscada no terreno teria sido ocasionada por uma mudança de compreensão da posição do homem perante o seu semelhante, momento a partir do qual passou a ocorrer um processo (constante) de aperfeiçoamento destas linhas. Da propriedade individual à coletiva, da casa à cidade, da cidade à província, e desta ao país, tudo tem limites, raias, cercas e muros, ou seja, apresenta características de posse de alguém enquanto indivíduo ou de alguma entidade social. O referido autor já afirmava, décadas antes da intensificação dos processos da globalização e da emergência do discurso do fim das fronteiras que: 
A fronteira é assim, em toda a parte, na Europa disciplinadísima, na América em preparo de uma civilização, nas largas extensões da Ásia e da África, na Oceania ainda imprecisada. É natural como a própria Natureza. Nasceu e há de morrer com o Homem, não obstante todas as utopias humanistas, embalde todos os sonhos de entendimento universal. (GOYCOCHÊA, 1943)

Na realidade, o aprofundamento da análise apresenta uma lógica global bem distinta daquela exposta de forma natural, coordenada e igualitária pelo discurso ultraglobalista. Para Cataia (2007), a expansão das coorporações e organismos internacionais, atreladas as suas normas e ordens globais não geram, de fato, uma integração passiva das partes. O mundo não se resume a economia e os fluxos não são apenas financeiros, mas também envolvem elementos migratórios, informacionais e culturais, tendentes à diferenciação. Desta forma, as dinâmicas globais não estariam "blindadas" das diferenças e das organizações internas das sociedades. As fronteiras e a compartimentação política continuariam existindo como obstáculos a tendência de homogeneização.

\begin{abstract}
A ideologia da união do mundo, que fundamenta o discurso do fim das fronteiras, obnubila as novas hierarquias da divisão internacional do trabalho. A criação de novas fronteiras políticas evidencia o oposto daquilo que é pregado pelo discurso da globalização econômica: de um mundo aberto à circulação, às trocas; de um mundo em que as novas tecnologias de transporte, especialmente as de informação, eliminam as compartimentações territoriais. O que se verifica é que quanto mais satélites são colocados em órbita, mais fronteiras são produzidas - ainda que para serem atravessadas -, ou seja, à medida que aumenta a densidade técnica planetária, o mapa político do mundo fica mais sincopado. (CATAIA, 2007)
\end{abstract}

Enquanto as dinâmicas globais tendem a unificação territorial pelas práticas econômicas, ocorre também conjuntamente, a compartimentação dos territórios, a diferenciação entre os homens, as firmas e instituições. Onde o meio técnico-científico-informacional manifesta-se mais efetivamente, imprimem-se novas relações entre os lugares e o mundo. Aprofundam-se as especializações produtivas dos lugares, assim como as relações de interdependência em função dos novos espaços da globalização. (GALLI, 2009)

Para Foucher (2009), a retórica dominante do "mundo sem fronteiras", enquanto discurso de uma conexão solidária e responsável entre a humanidade, apresentaria um caráter insignificante ao tentar resumir o mundo a um mercado plano. As fronteiras, embora tenham perdido importância na atualidade - não em 
todos os lugares - seriam extremamente necessárias para a existência de um mundo habitável.

Cesar e Albuquerque (2012), ao questionarem o processo de banalização das fronteiras, apontam para a permanência de assimetrias internacionais, conflitos territoriais, guerras e também disputas econômicas. Segundo os mesmos, o sistema capitalista não seria tão cooperativo como as ideias globalistas tentam apresentar, pelo contrário, seria, na verdade, formado por Estados e economias competidoras. Além disso, a divisão internacional da produção e da riqueza não apresentariam um grau de rigidez capaz de impedir o efetivo exercício de controle das fronteiras por parte dos governos das distintas unidades políticas.

O folclórico e simplório discurso do "mundo sem fronteiras" estaria, na realidade, no interior de uma retórica difundida como forma de legitimação da ideologia neoliberal, sendo utilizada para justificar a aniquilação das localidades e do território pelas forças globais e pelo capital, colocando a lógica global acima dos interesses reais das pessoas (YEUNG, 1998).

Segundo o mesmo autor, o sistema estatal não estaria ocupando uma mera posição de instrumento do capital. Mesmo na era da globalização, o Estado continua apresentando papel fundamental na economia mundial e no reforço da questão da territorialidade. É o mesmo que proporciona as condições mínimas para a reprodução do capital - fatores de produção, direitos de propriedade, ordem social, etc - adaptando-se e reorientando suas políticas de acordo com os novos desafios impostos. Além disso, o próprio capital não apresenta atuação idêntica em qualquer local do planeta, sendo, de fato, influenciado pelas características locais - vide os inúmeros exemplos de diferenças substanciais de um mesmo produto dependendo do país onde é produzido e comercializado. 
...Territorial differences and geographical unevenness remain integral to globalizing processes. The world is made up of a dynamic mosaic of uneven geographical formations that are shifting over time, subject to the interplay of power relations among the state, capital and other forms of social institutions. The analytic logic of a 'borderless' world becomes absurd in this interpretation of ongoing changes in the global economy, because by portraying an end-state, it fails to recognize its dynamic transformations over time and space. Instead, we should recognize the qualitative and dialectical nature of globalization and its key actors, in order to understand and explain the world in which we are living. There comes a point when we must raise our heads from books by ultraglobalists, look around and reconsider whether borders have really disappeared, and whether the world is, in fact, a unified whole!. (YEUNG, 1998)

De acordo com Moraczewska (2010), a continuidade da importância das fronteiras também ocorre no interior das Relações Internacionais, dentro do chamado paradigma realista (em oposição aos paradigmas transnacional e global, já apresentados). Neste, as fronteiras continuam sendo caracterizadas por efetivas linhas de determinação de nacionalidades e separação do "nós" e "eles", não perdendo de forma total sua função primordial de barreira, algo que seria comprovado pela permanência e restauração de estruturas de retenção de fluxos e de sua militarização em muitas partes do mundo. As linhas fronteiriças refletiriam assim a permanência da preponderância dos interesses e necessidades de segurança em detrimento dos ganhos econômicos possíveis com a cooperação e integração transfronteiriça. Os atentados de 11 de setembro de 2001, por exemplo, além de dificultar a entrada de estrangeiros em território americano de uma forma geral, também seriam determinantes para a adoção de políticas mais rígidas nas díades ${ }^{1}$ norte americanas (EUA-México e EUA-Canadá).

De fato, o que se pode notar é que as fronteiras não desapareceram, apenas apresentaram modificações e perdas de algumas de suas funções - uma refuncionalização de acordo com Evangelista (1998) - ao mesmo tempo que houveram retomadas e consolidações de outras. Segundo Raffestin (1993), o processo de estabelecimento de limites territoriais entre as diferentes unidades permite o exercício de três funções principais: legal, de controle e fiscal. A primeira, delimitaria uma área no interior da qual prevalece um conjunto de instituições jurídicas e normas que regulamentam a existência e as atividades de uma

\footnotetext{
${ }^{1}$ Termo cunhado por Foucher (2009) para designar o limite compartilhado por dois países, podendo ter sua concepção extendida para outros tipos de unidades político-administrativas, tais como estados, municípios, distritos, etc.
} 
sociedade. A segunda teria como propósito a inspeção da circulação de bens e da informação de uma maneira geral. A terceira, por sua vez, estaria ligada a política econômica e as ações protecionistas dos Estados.

Desta forma, como aponta o referido autor, o pensamento de que as três funções ocorrem de forma concomitante em todas as fronteiras estaria equivocado. Com os processos de cooperação e integração gerados pela globalização podemos encontrar casos em que ocorreram, de fato, a perda das funções de controle e fiscal das linhas fronteiriças. O fluxo cada vez mais intenso de pessoas e de mercadorias seria responsável por esta mudança de paradigma. Entretanto, a mesma afirmativa não poderia ser feita para a função legal, a qual estaria sempre presente. Tomando como exemplo a União Europeia, pode-se facilmente observar que as fronteiras políticas entre os Estados membros continuam a existir mesmo com a abolição da necessidade de vistos e da taxação de mercadorias no interior do bloco. As normas particulares de cada país continuam a vigorar dentro do respectivo território, ou seja, dentro do espaço delimitado por suas fronteiras.

\footnotetext{
O conceito de mundialização entrou na ordem do dia, mas nem por isso os regionalismos, os particularismos, deixaram de existir. A ideia de "blocos de países", visando obter ganhos de escala parece por si contradizer a tese do "fim das fronteiras". Ao contrário, são novas fronteiras que estão surgindo, as "interblocos", e acrescenta-se, sem que as "nacionais" tenham deixado de existir. (MARTIN, 1992)
}

Considerando o período compreendido entre os dias de hoje e o início da década de 90 do século passado, notadamente tido como aquele em que houve a intensificação dos processos de integração mundial com o fim da bipolaridade gerada pela Guerra Fria, pode-se notar que a cena fronteiriça não apresentou processos de homogeneização e de simplificação. Como demonstra Foucher (2009), mais de 26 mil quilômetros de novas fronteiras internacionais foram instituídas a partir da desintegração do antigo bloco soviético e do fim da ex-lugoslávia, ou até mesmo pela independência de novos países (caso do Sudão do Sul como o mais recente). Em adição a isto, outros 24 mil quilômetros foram objeto de acordos entre os Estados confrontantes. Hoje, o mundo atual apresenta 332 limites comuns entre Estados em nível internacional, totalizando uma extensão considerável de 248.000 
quilômetros (valor equivalente a 20 voltas equatoriais ao redor do globo terrestre). Os avanços tecnológicos permitiram um significativo aumento de precisão e confiabilidade dos processos de delimitação e demarcação, além da própria capacidade de vigilância e patrulhamento, tornando, desta forma, as linhas fronteiriças cada vez mais visíveis e não invisíveis como afirma Ohmae (1999).

Dentro deste cenário, nota-se também o surgimento de alguns programas internacionais direcionados a questão fronteiriça. A União Africana, em 2007, lançou o seu Programa Fronteiras, destinado à demarcação e caracterização de díades do continente, impostas pelos colonizadores e possíveis focos de tensão em caso de reabertura de antigas quirelas. O programa Frontex, por sua vez, surge como uma tentativa da União Europeia de proteger suas bordas externas, impedindo a entrada de imigrantes ilegais. Neste caso, a integração ocorrida no lado de dentro não ocorre para o lado de fora. O grande número de imigrantes provenientes de várias partes da África que tentam, diariamente, cruzar o Estreito de Gibraltar em busca de melhores condições de vida, descobre, in loco, que as fronteiras continuam presentes.

Além disso, a era "iniciada" com a queda de uma das mais famosas e midiáticas fronteiras do mundo, o Muro de Berlim, também apresentou a continuação e a construção de estruturas semelhantes (figura 1.2-3). Se a globalização derrubou as fronteiras políticas, como explicar, principalmente para as pessoas diretamente envolvidas e afetadas, os muros e cercas existentes, por exemplo, nas díades IsraelPalestina, Coréia do Sul-Coréia do Norte, Chipre-Chipre do Norte, MarrocosSahaara Ocidental? 


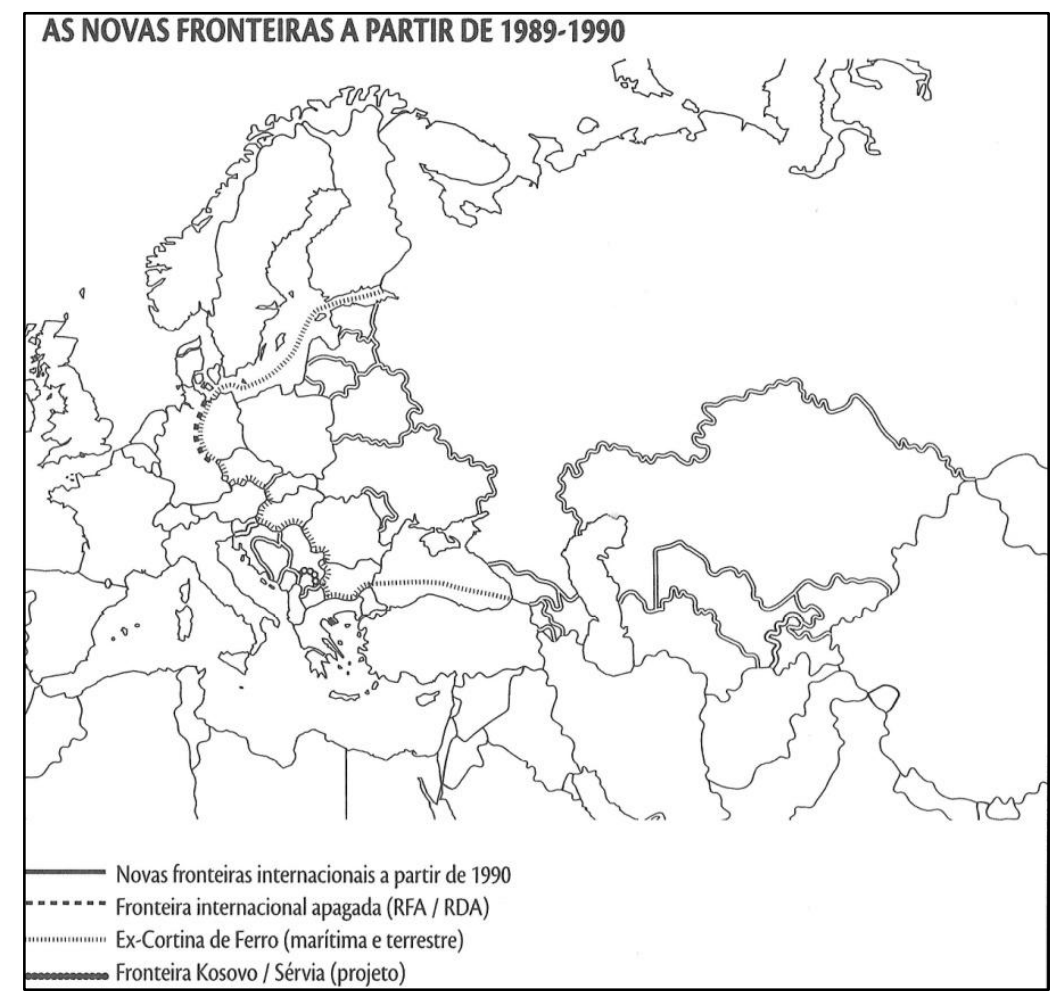

Figura 1.2-1 - As novas fronteiras a partir de 1989-1990. Fonte: Foucher (2009)

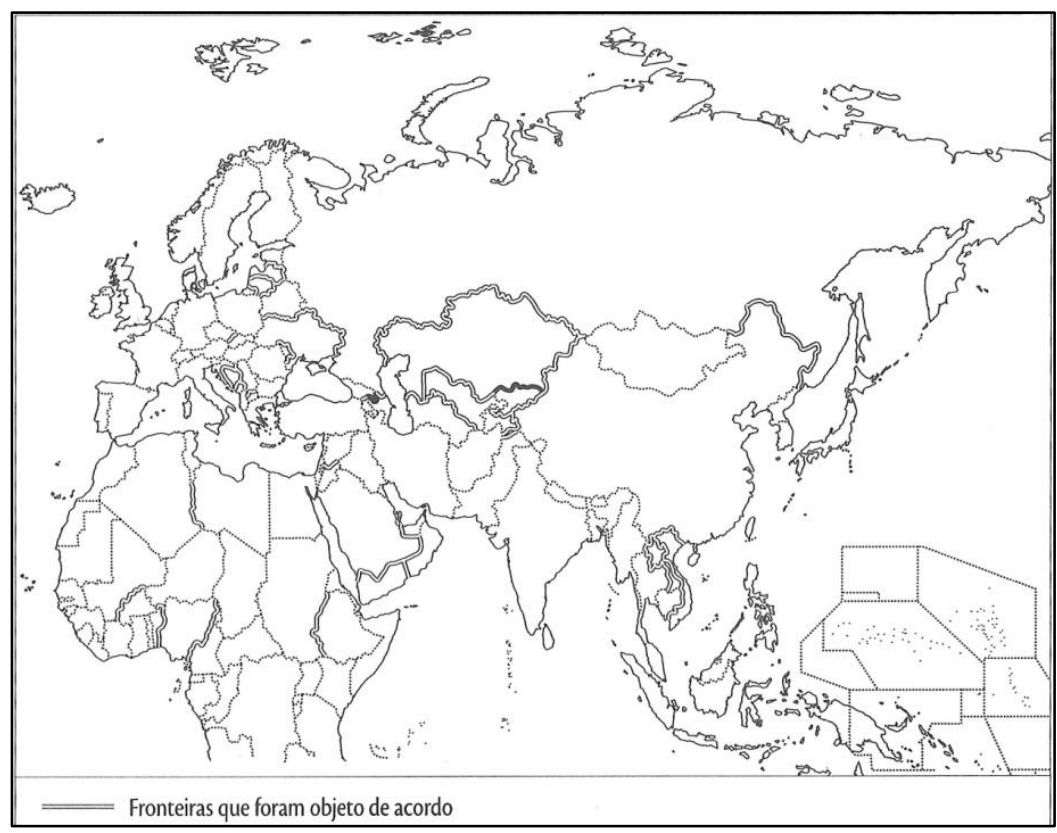

Figura 1.2-2 - Principais regulamentações de fronteiras - 1989-2009. Fonte: Foucher (2009) 


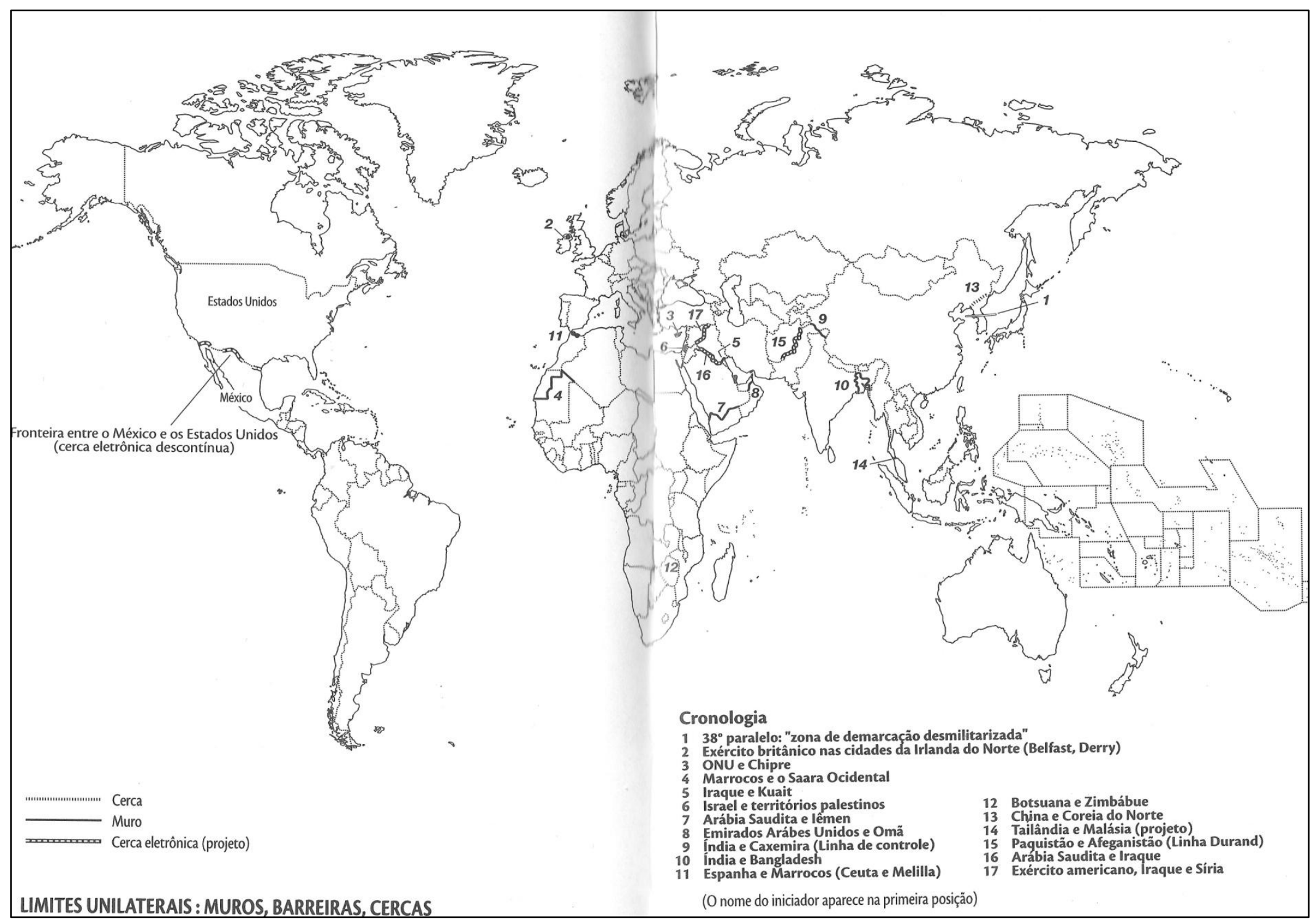

Figura 1.2-3 - Limites Unilaterais: Muros, Barreiras, Cercas. Fonte: Foucher (2009) 


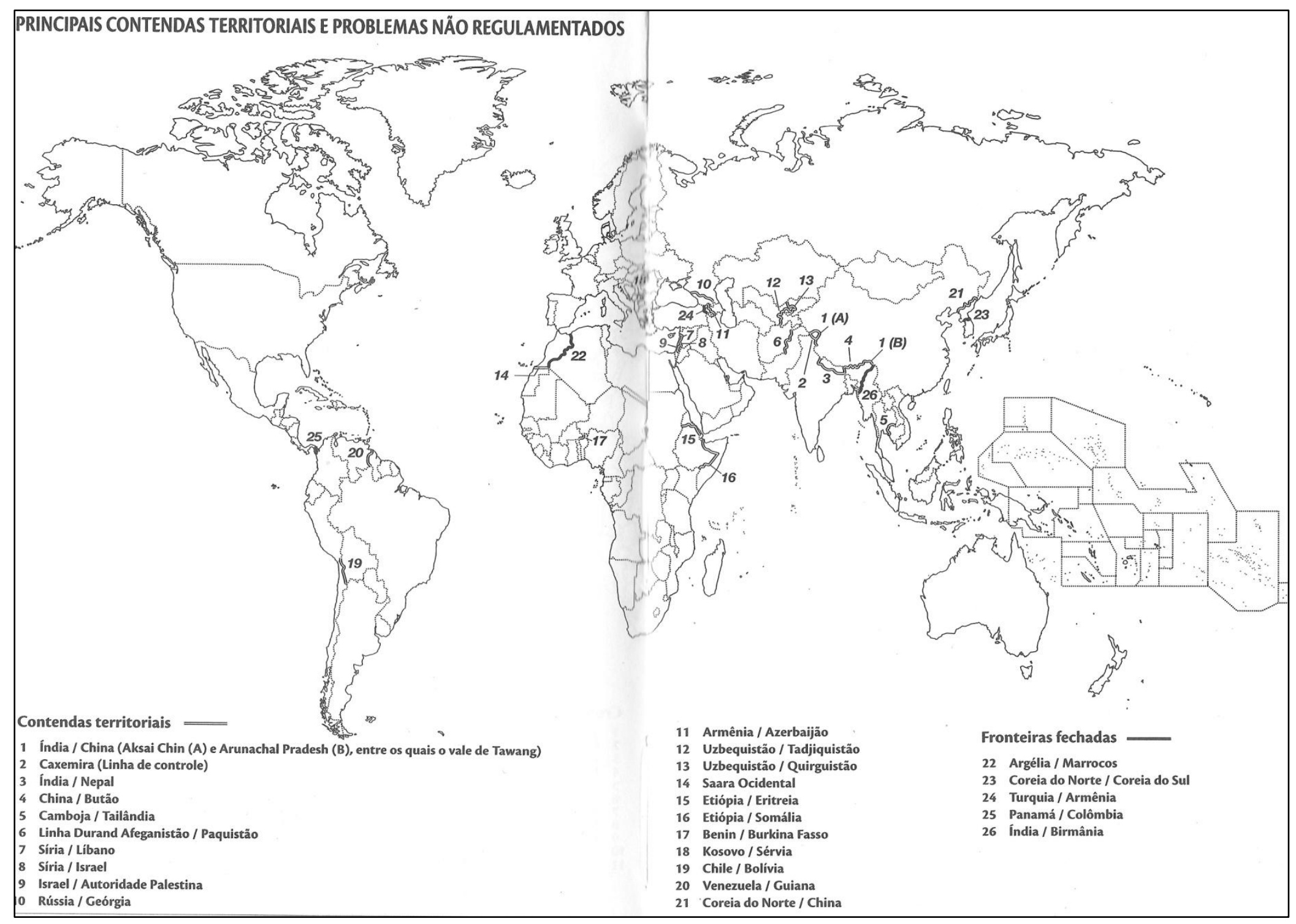

Figura 1.2-4 - Principais contendas territoriais e problemas não regulamentados. Fonte: Foucher (2009) 


\subsection{A QUESTÃO DOS LIMITES INTERNOS}

Tradicionalmente, seja na geografia ou em qualquer outra área que estude o assunto, a temática das fronteiras é comumente analisada sob a ótica dos limites internacionais. Trabalhos de caráter histórico, descritivo, econômico, político, etc., tendem a se concentrar nas linhas de separação entre os diferentes países. Neste cenário, a questão das fronteiras internas ocorre de forma residual, ligada principalmente ao estudo de casos específicos.

Neste momento, é válido o destacamento da classificação das fronteiras apresentada por Prescott (1965). Segundo o mesmo as linhas fronteiriças poderiam ser separadas em dois grandes grupos - as internacionais, entre os diferentes países, e as intra-nacionais, as quais, por sua vez, subdividiam-se em federais - de separação entre estados de um federação - e internas - entre unidades administrativas em estados unitários ou dentro dos estados federados de um país. Já autores como Martin (1993), Cataia (2007) e Galli (2009), ao focarem suas análises no interior da realidade brasileira, não apresentam a mesma divisão acima citada. Para os mesmos, todos os tipos de limites intra-nacionais estariam englobados enquanto fronteiras internas.

A distinção entre os limites internos e externos também fora considerada, segundo Backheuser (1952), por Ratzel, no que tange a sua relevância para o Estado. Este tinha a fronteira como um órgão periférico do Estado, estando mais relacionada à mera questão administrativa de um sistema federativo em seu interior, apresentando, inclusive, um menor conteúdo político se comparada às fronteiras internacionais, muito mais importantes quanto à configuração externa estatal.

Essa visão será compartilhada pelo referido autor, o qual considerava as fronteiras internas como inexistentes, uma vez que as mesmas, não atrapalhando o fluxo entre pessoas e mercadorias e, não possuindo qualquer caráter militar, estariam restritas a simples separação entre as diversas unidades políticas e administrativas do país. 
Em interpretação distinta, Martin (1993) afirma que as fronteiras internas possuem a mesma importância para o Estado que as fronteiras externas, servindo ao mesmo tempo como base e instrumento da divisão social e territorial do trabalho.

Dentro disto, Galli (2009) considera que as fronteiras internas não podem ser consideradas como meros limites político-administrativos, uma vez que "em países como o Brasil, onde os Municípios também são entes da Federação, com poder de legislar sobre sua circunscrição, as compartimentações não podem ser reduzidas ao seu aspecto administrativo." (GALLI, 2009).

De fato, uma análise mais aprofundada revela que os limites internos apresentam grande relevância na vida cotidiana das pessoas, influenciando as mesmas de forma mais intensa e direta do que os próprios limites internacionais. São estas linhas que determinam a localização de eleitores, a implantação de escolas, atendimentos em postos de saúde, entregas de correspondências, implantação de linhas telefônicas, cadastramentos pra fins escolares, recolhimento de lixo, pesquisa para censos demográficos, ocorrências policiais, telefonia, abastecimento de água e luz, melhoramentos em vias de acesso, entre outros (PRESCOTT, 1965). Em suma, são estas linhas que regulamentam a oferta e o acesso aos serviços mais básicos e essenciais.

Como bem aponta Cazzolato (2011):

\begin{abstract}
Há que se lembrar, também, que a partição territorial, com a trama de fronteiras internas, ao mesmo tempo que constitui o arcabouço da federação, embasando nossas identidades e liames de cidadania, compreende também funções mais prosaicas, operando na organização do varejo da burocracia estatal, da atividade econômica, dos calendários culturais e esportivos, das planilhas fiscais municipais, da aplicação de políticas públicas, etc. (CAZZOLATO, 2011)
\end{abstract}

Neste contexto, as considerações de Raffestin (1993) merecem destaque novamente. Enquanto as funções de controle e fiscal podem ou não ocorrer com o estabelecimento de limites territoriais internos, a função legal é intrínseca aos mesmos, determinando um conjunto de leis estaduais, provinciais, municipais, distritais, etc., de valor considerável apenas para o território delimitado por suas linhas fronteiriças, não apresentando qualquer influência de cunho jurídico para as 
áreas "externas". O que aparentemente pode ser considerado como trivial, de pequena importância em comparação com as leis nacionais, desponta como algo de extrema relevância em situações de alterações bruscas de um quadro legal vigente, principalmente em situações de evidente contraste com seu entorno.

Tomemos como exemplo um conjunto de municípios de produção destacada de determinada cultura agrícola. Em um primeiro momento, não havendo qualquer tipo de restrição legal, é esperado que a distribuição das plantações ocorra ao longo dos territórios municipais em função de fatores de cunho econômico, logístico, etc. Considerando uma situação hipotética de proibição da referida cultura em um dos municípios, tem-se uma modificação substancial de cenário, dentro do qual o limite municipal "surge" como um novo - e crucial - elemento para determinação das áreas produtivas possíveis.

Dentro de um enfoque quantitativo, o panorama mundial atual aponta, segundo o levantamento realizado pelo sítio eletrônico Global Administrative Areas, para a existência de 556.049 divisões político-administrativas de caráter interno aos países (218.238 levando-se em conta apenas o nível mais baixo de divisão de cada país). A partir destes números e da consideração de que a quantidade de díades esteja próxima - ou até mesmo ultrapasse - o número de 1 milhão, é de fácil percepção a importância e a presença considerável dos limites internos. Mesmo que de "mero" caráter administrativo, os mesmos são utilizados em praticamente todos os países como forma de organização da estrutura estatal e das políticas públicas. Neste contexto, subdivisões como estados, províncias, regiões, municípios, condados, distritos, etc. completam o mapa político do mundo, comumente representando apenas através dos limites internacionais.

Os referidos dados também demonstram que as divisões territoriais internas não ocorrem apenas em territórios de grande extensão e/ou de relevante população, como comumente pode ser imaginado. Ao mesmo tempo em que países como a França e o Brasil apresentam elevada repartição territorial (figuras 1.3-1 e 1.3-2), microestados como San Marino (32.140 habitantes e área de $61 \mathrm{~km}^{2}$ ) e Liechtenstein (36.713 habitantes e área de $\left.160 \mathrm{~km}^{2}\right)^{2}$, também têm seus territórios nacionais retalhados por díades internas (figura 1.3-3). Desta forma, pode-se constatar que a 
divisão territorial interna de um país ocorre em meio a um conjunto de fatores políticos, econômicos, históricos, culturais e sociais, não existindo valores previamente fixados de extensão territorial e de população a serem considerados para tal.

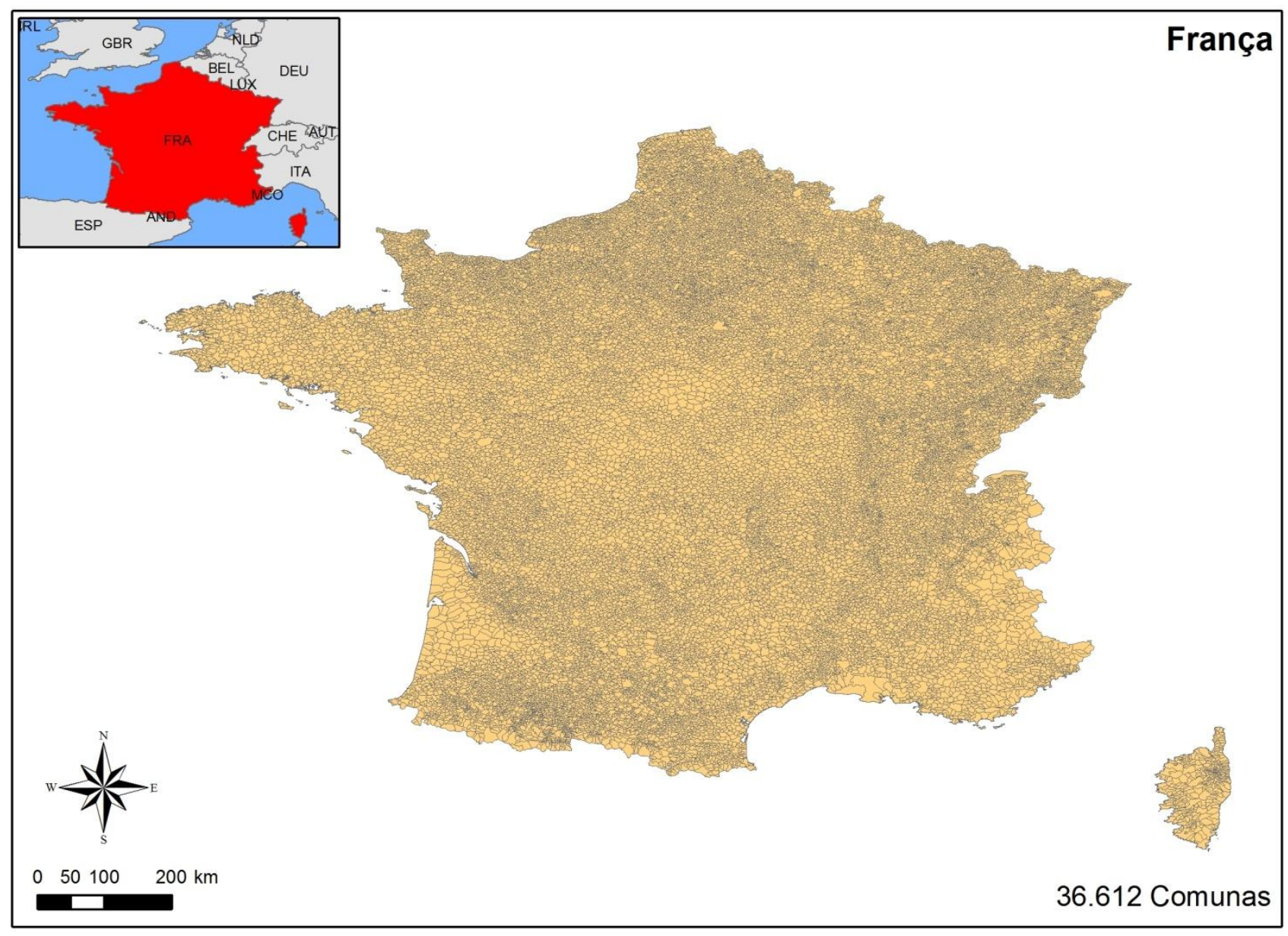

Figura 1.3-1 - Comunas - Unidade básica de organização territorial na França. Fonte: GADM (2013) 


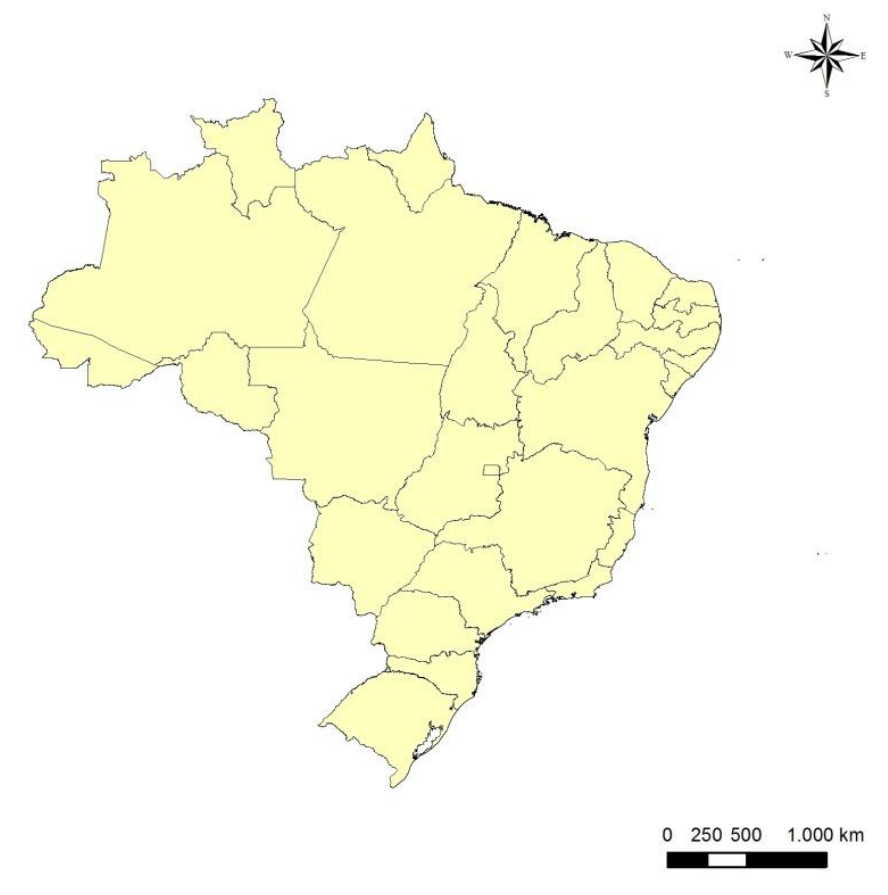

26 Estados e 1 Distrito Federal

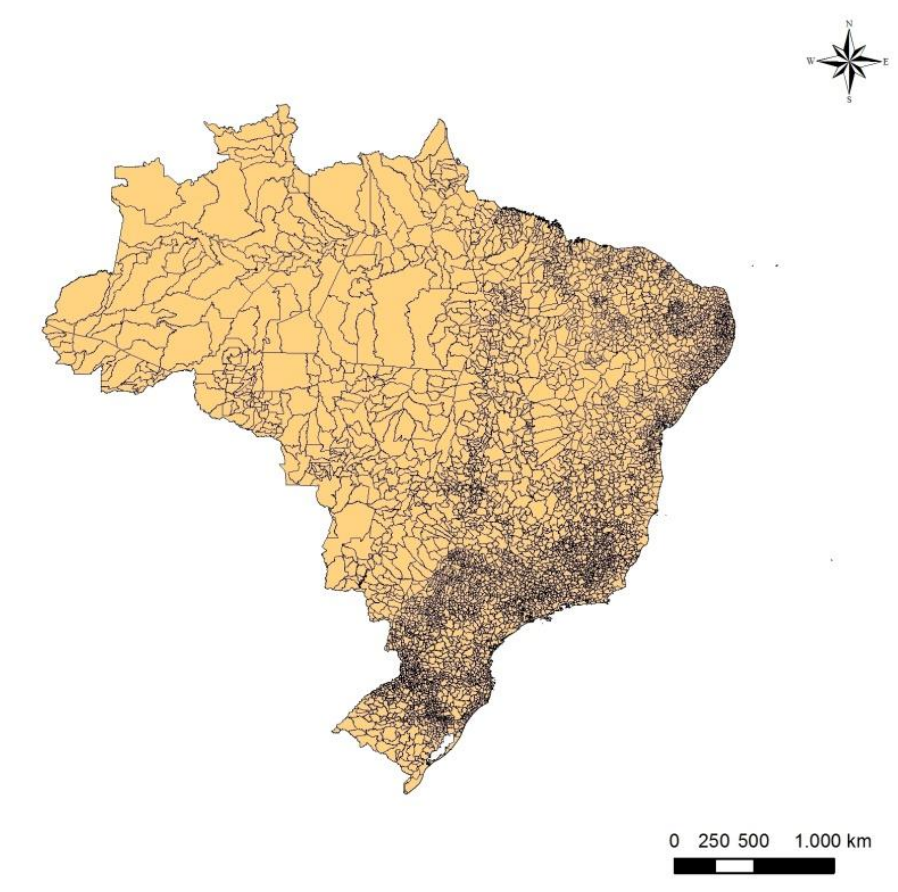

5.565 Municípios

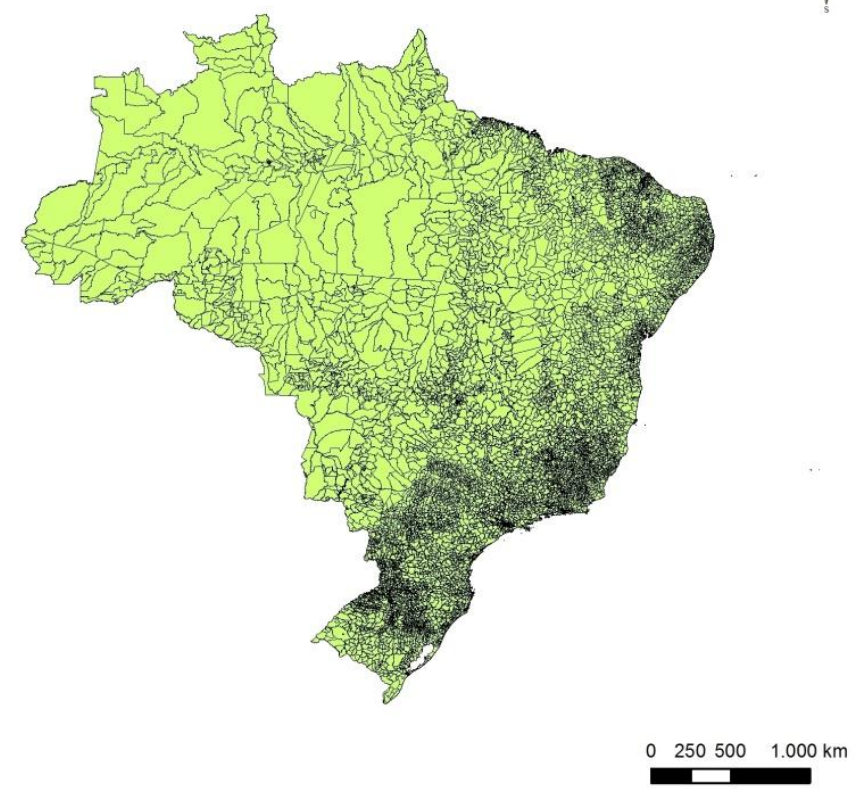

10.283 Distritos

Figura 1.3-2 - Divisão Territorial do Brasil em 2010. Fonte: GADM (2013) 


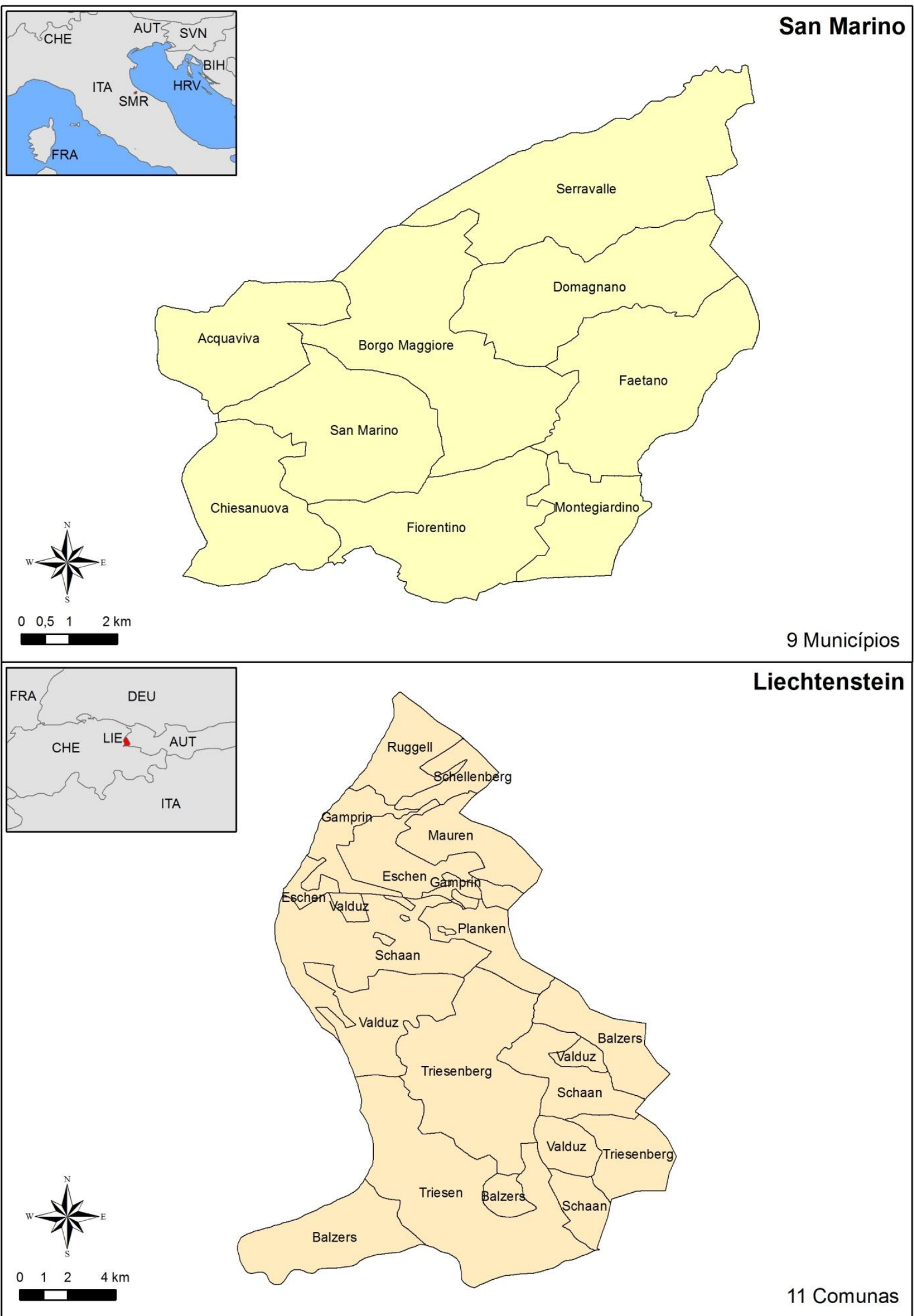

Figura 1.3-3 - Divisão Territorial da República de San Marino e do Principado de Liechtenstein. Fonte: GADM (2013) 
Em meio a tal importância surgem também os problemas. Uma área fronteiriça com expressivo valor econômico, populacional, eleitoral, etc., ao estar localizada próxima ao limite entre dois estados ou municípios, pode, de fato, ocasionar situações prejudiciais para os moradores locais. O embate político causa uma espécie de "confusão territorial", tanto na mentalidade da população quanto na própria administração pública. A busca pelo reconhecimento legal de jurisdição da área leva à ação direta de instituições públicas provenientes de dois poderes distintos.

Mas, se a oferta de serviços públicos pode ser "dobrada", esta também pode ser negligenciada. Em uma situação inversa, onde as áreas limítrofes não detêm qualquer valor que possa justificar, aos olhos da administração pública, os gastos com as mesmas, pode-se encontrar uma espécie de jogo de ping-pong entre as duas (ou mais) unidades políticas-administrativas vizinhas, objetivando a transferência do ônus para o outro. A linha de limite mal definida, mal interpretada ou de difícil identificação no terreno surge então como oportunidade para ações de anexação territorial ou de ausência do poder público em determinadas áreas (figuras 1.3-4, 1.3-5 e 1.3-6). Neste sentido, Moreno e Souza (2010) demonstram, em pesquisa realizada nas "bordas" do município de Belo Horizonte, como o limite influencia diretamente a vida dos moradores destas áreas periféricas, onde morar em cima da linha pode significar pertencer a dois ou mais lugares ou não pertencer a nenhum. Segundo os mesmos:

A oferta de serviços públicos nas regiões de limites entre um município e outro nunca é a mesma nos dois lados. O limite é o local do choque entre Municípios, ao invés de ser o do encontro. Metade de uma rua pode ser asfaltada, e a outra de terra; parte pode ser iluminada, e do outro lado é preciso ligações clandestinas para se ter luz dentro de casa; um morador pode ter o direito de estudar na escola da comunidade ou ir a um posto de saúde, perto de sua casa, enquanto seu vizinho deve cruzar vários bairros até chegar ao equipamento público pertencente à sua jurisdição; o lixo é recolhido somente até determinado ponto da rua, onde termina o município, permanecendo a outra metade suja, inutilizando o serviço de coleta parcialmente realizado. Nos limites, podem-se receber contas a pagar provenientes de dois ou três Municípios; ter dificuldades no acesso à infraestrutura urbana, à segurança pública, ao serviço de transporte público, dentre outros. Na busca pelos melhores serviços do poder público, os moradores dessas regiões não somente recorrem àqueles ofertados pela administração do município onde, supostamente, residem, como também aos do município vizinho, burlando normas administrativas municipais e a legislação. (MORENO e SOUZA, 2010) 


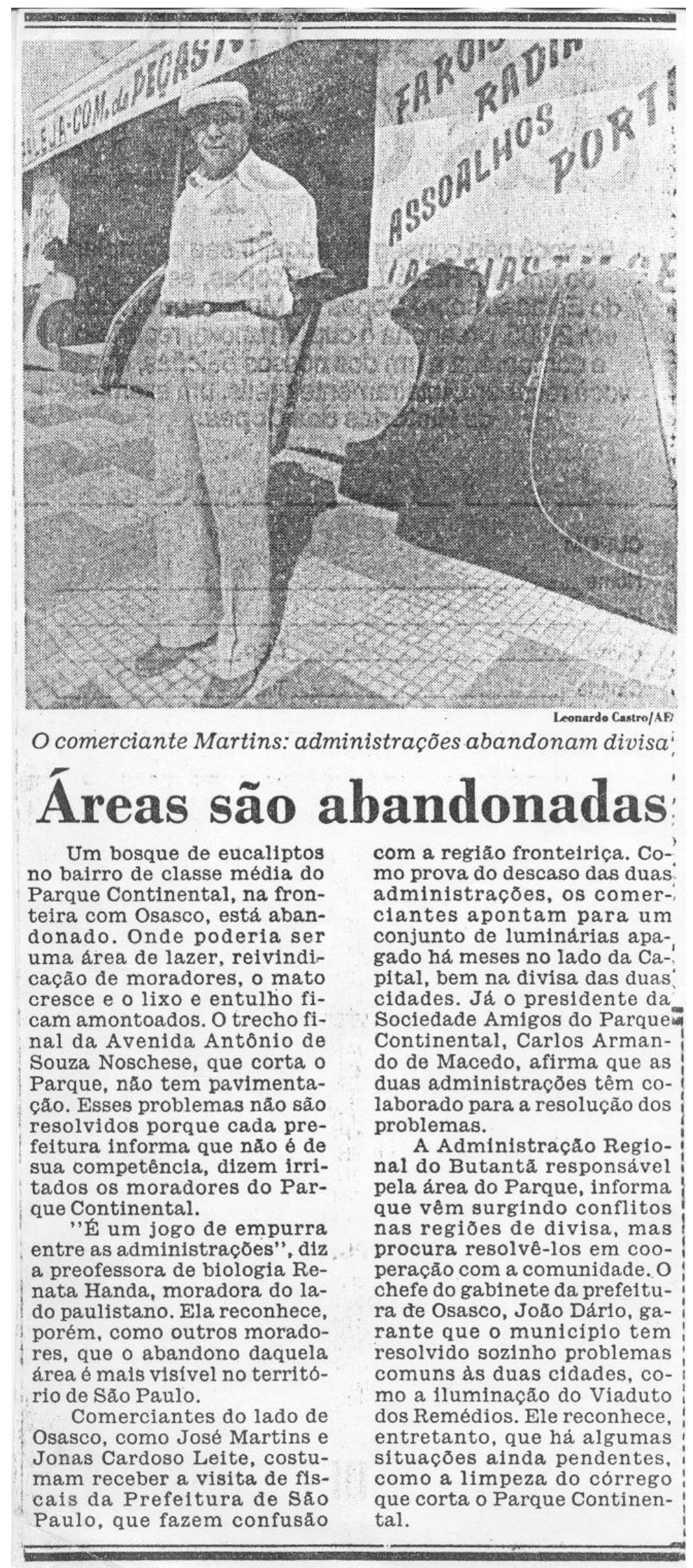

Figura 1.3-4. Fonte: O Estado de São Paulo, 01/07/1990, pg. 32. (Acervo GDAT-IGC/SP) 


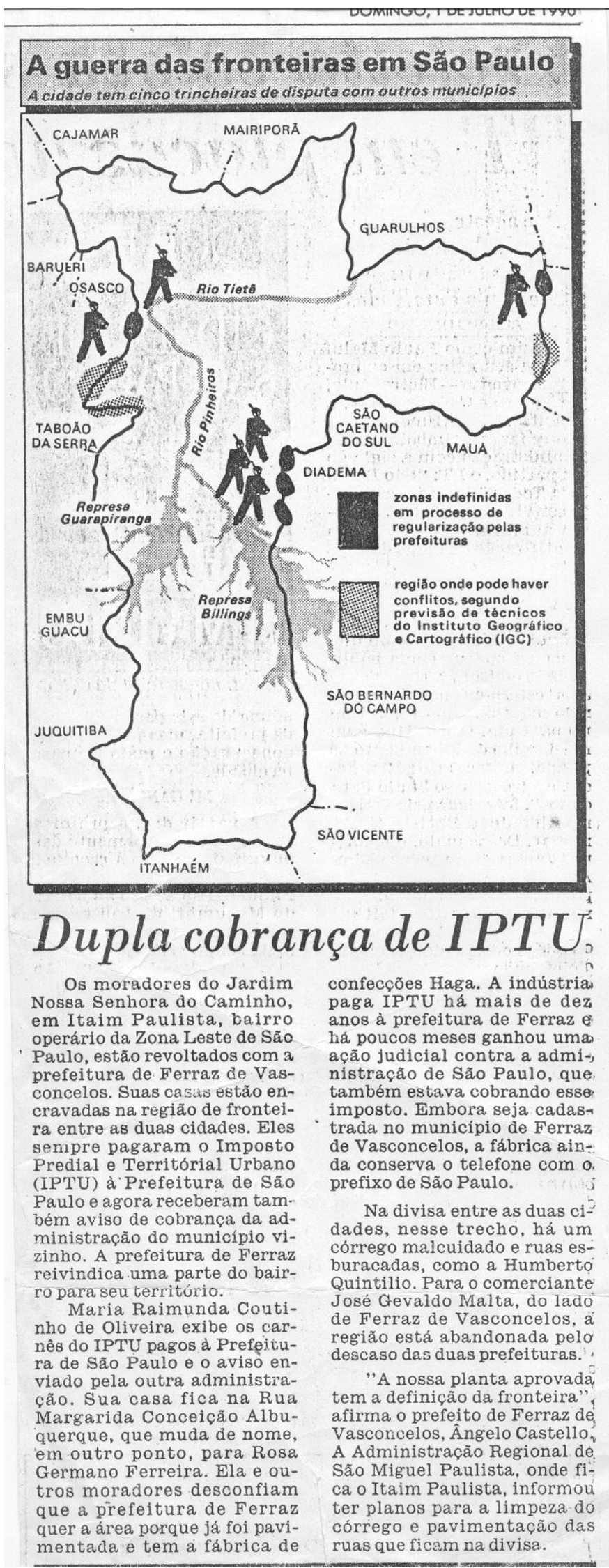

Figura 1.3-5. Fonte: O Estado de São Paulo, 01/07/1990, pg. 32. (Acervo GDAT-IGC/SP) 


\section{São Paulo trava guerra \\ com municipios vizinhos}

São problemas nas divisas com Osasco, Diadema e

Ferraz de Vasconcelos

\section{JOSÉ LUZZ LIMA}

ADs 158 anos, o municipio do São Paulo não tem ainda ansa divisas definitivamente demarcadas. Existe uma "guerra de fronte1ras" com as cidudes de Diadema, Ferraz de Vasconcelos e Osasco. Outros conflitos deverso aparecer em areas de Itmites com a Captta] areas de limtes com a cipttal berizadas, soxundo previsũo dos técnicos que trabalham para encerrar os litigios. Fasa "guerra" atinge airetamente o contribuinte: nšo 6 beneficisdo com melhoramentos urhanos e, em multos casos, recebe a controcacto para o pagamento de impestos dis duss prefeituras.

Fose tipo de conflito fics claro, por exemplo, na divisa de Sío Puulo com Osasco. Num ponto de fronteirs, entro na doia municipios, o prefeito de Osazco, Franciaco Rossi. riscou no asfalto uma ralxa amsrela e escreveu de um lado "Sio Paula" e do outro o nome de aua cidade. A ratxs pintade no astalto ficn junto a entrada de Osasco, na dir com o Parque Contincritol, na Zona Oeste da Clapition to mortoras dr moradors, o prefelto methorou aquela área a agora quer deixar claro que sli comech outro municiplo.

"OB conflitos normalmente aparecem quando ocorre bitríbutaçso, ou seja, a cobrasca de $\mathrm{km}$ mesmo tmposto mir duiz inetitutenef. no caso a. prefeir.uma", friforma Jan Ribelro, assessora do Depar-

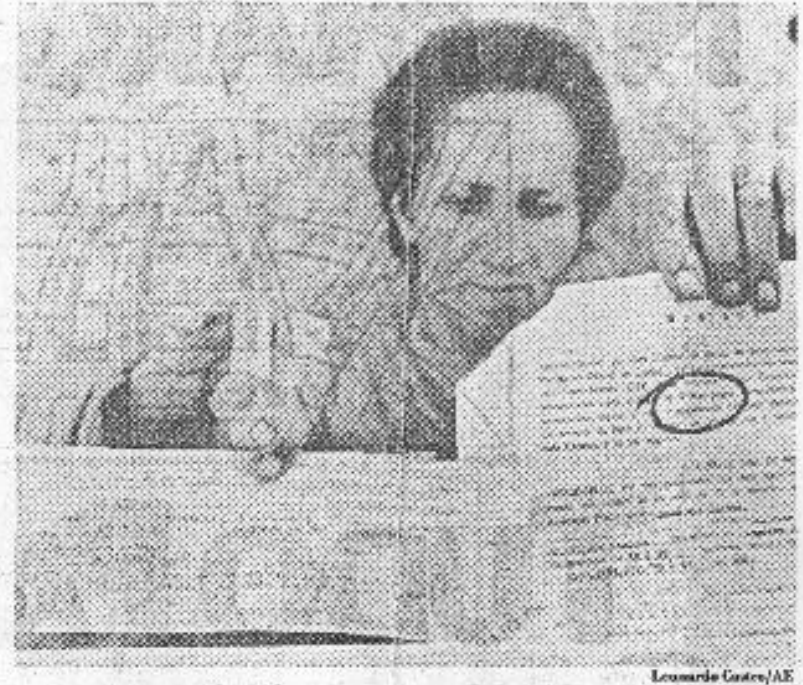

Maria Raimunda: IPTU cobracio por dois munictplos

termento de Rendas Imobiliarias, da Secretarta de Finanrias. da secretarsa de FinanFla explica que esse problema Ela explica que esse probicma de bitributaçá existia com o meca a ser fesolvico, e agora ocorre entro Säo Paulo e Ferras de Vasconcelos. DEMatrcac̃̃o

Grupos ce estudos estio sendo formudos, com integrantes dos muricipios envolvidos $\mathrm{ns}$ disputa, park definir os nowos limites a assim livrs os moradores desag "'monas cinzontas" de brtmbitiogas da ausencia ac henelicios ar banos, A prop:ia Constituiça Federal preve em seu artige 12 , parágrafo $2^{\circ}$, das Dispo: ches Transitórias, çue" os Ea tacos a municfios daverko. nu praso de trés anca (até ontulire do ano vam, promove a demareacin de suas linhos: divisórias stuslmente litikioSals"

Os trechns conflitantea dos limites de sio l'auloe Osasco e com Ferraz de vasconcelos à̃o córregus, que es. thio sempre com detritos e 11 xo. Cada administracaso informa que o problema deve ser combatido pelo outro lado. Ns. divisa com Diudems, ni Zons (Sill de Sa Puulo onde roa 0 Par de 7 do Setembro os a Parque tas setembro, os meóm nüo chegam, justamente por easa confusto encre as prefeituras. Doa 287 quilómetroa de extenkas das fronteiras de Sũo Pau10, ex1stem conflitos corn os upreximeds de 16 qutlómetros.

Os cortribusntea dessas átons contitantes podem enfrentur problemaa domest1ens, eomo a crruslizs,ço de um trés municipios nama fres. corrego, asfaltamento de ruas, colocacăo de linha de 3ntbu alem da bstruthuta cin" explica o enusteto sercho explica o areasteto serglo Zeratin, thsicssor da presidéncia da Empresa Metropolitana de Planejamonto da Grande Sá Paulo S.A. (Emplasa). Ile aftrma tambem que a prefeitura, multas vezes, deixa de assumir eases servicos por fulrar aue a rogiso n⿺尢丶 pertence ao geu territorto.

Toda área urbanizade a partir de 1964, quando foi foita i. ultima revisa de fronteiras do Municiplo de sáo Paulo. estri sujoita a confutos nas divias. A avaliação é do gecgrafo Joaé Soares Aquirro, do Inst1tuto Geográfico e Cartosrúfico (I.G,C), da secretsria estaduel de ICconomis e Planejamento A I1nha cue demares as limites de Sino panlo

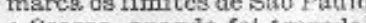
e Oassco, quando fol trucade. em inumeros pontos ers dess bitida. "Esaa linha hoje 6 irrucional, pois corta ao melo loteumentos e ruas, por 1aso deve ser alterada", explicia Asuirre.

Ao IGC compete o estudio e definicio des frontwiras dos municipios gaulistas e também com outros Estados . E esse instituto o responsdrel velas altersoges feita a peili do de prefelturas on que pur gem por melo de uma retifle gĩ lo melo de uma retiricessho de rib ou ourrego. Notmalmonte, a iniciativa dessaa mofifiençōes psarto dos municipios interesssdos, poir para o $\mathrm{IGC}$, prevalece a fronteira já deflnida nos mapss anteriormente tracados, coniorme $\mathrm{In}$ meme trosion forma obecgra cobaervanin

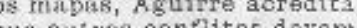
que butros conthtos devem avarecer, em runças do processo de ocupacaso dessas reGảes sronteiripas at tempo atrds desabitsdas.

Figura 1.3-6. Fonte: O Estado de São Paulo, 01/07/1990, pg. 32. (Acervo GDAT-IGC/SP) 
No Brasil, é justamente durante o período de intensificação da globalização (a partir do fim da década de 1980) que irá ocorrer um acelerado processo de fragmentação territorial, mediante, primordialmente, a criação de uma quantidade significativa de municípios e da apresentação de inúmeras propostas de estabelecimento de novos estados federados. A busca ou a efetiva criação destas novas fronteiras políticas não apresentam um embasamento comum, pelo contrário, assim como aponta Cigolini (2009), são passíveis de origens e significados distintos. A revisão bibliográfica realizada pelo referido autor aponta para a existência de eixos causais diversos para a compartimentação territorial em questão. São elas:

- Grande extensão territorial da unidade político-administrativa de origem, bem como a presença ou ausência de atividades econômicas, pobreza local, urbanização e capacidade de organização de grupos;

- Estratégias políticas - emancipação entendida como forma de alcance de representatividade política e vantagens econômicas e eleitorais ou como uma possibilidade para um desenvolvimento local;

- Fatores de gestão administrativa - descaso de administrações públicas e ausência de serviços públicos;

- Expansão de sistemas de circulação e do aumento populacional;

- Manipulação do território por atores hegemônicos;

- Fatores normativos institucionais e políticas de descentralização.

No âmbito estadual, apesar da criação efetiva de um novo estado no país não ocorrer desde o surgimento do Tocantins a partir da Constituição de 1988, o debate sobre propostas de novas unidades do tipo não é desconsiderável. Em uma breve análise histórica, faz-se possível notar que a problemática da divisão territorial da federação sempre esteve presente nas esferas parlamentar e acadêmica. Da divisão inicial em capitanias hereditárias até a atual configuração federativa - 26 estados e 1 distrito federal - inúmeras propostas foram idealizadas em busca de uma maior equilíbrio econômico, demográfico e político entre as distintas unidades. De acordo com Guerra e Guerra (1960), a primeira alternativa de redivisão territorial do Brasil teria ocorrido em momento anterior à promulgação a Constituição de 1824, mediante a proposta de Antônio Carlos, baseada no modelo francês de departamentos e comunas. Em sequência poderiam ser destacadas, segundo o levantamento de 
Cigolini e Nogueira (2012), as "sugestões" de Francisco Varnhagen (1849); Fausto de Sousa (1880); Ari Machado Guimarães (1932); Sud Menucci (1933); Raul Vieiras (s/d); Bandeira de Mello (s/d); Paulo Frontin (s/d); Segadas Viana (1933); Everardo Backheuser (1933); Juarez Távora (s/d); Xavier Oliveira (s/d); Teixeira de Freitas (1941); Antonio e Ignez Teixeira Guerra (1960); André Roberto Martin (1993); Henrique Laje (s/d) e Teodoro Almeida (s/d). Mais recentemente, o geógrafo José Donizete Cazzolato, em seu livro Novos Estados e a divisão territorial do Brasil: uma visão geográfica, publicado em 2011, propõe, a partir da elaboração do conceito de padrão territorial baseado em população, área territorial e número de municípios, 37 unidades federativas (33 estados, 3 territórios federais e 1 distrito federal) (figura 1.38).

O recente plebiscito (outubro/novembro de 2011) que impediu a criação dos estados do Tapajós e de Carajás a partir do redesenho fronteiriço do estado do Pará pôde demonstrar como a questão territorial apresenta valor considerável, apresentando um envolvimento efusivo da sociedade paraense como um todo. Apesar da derrota destas propostas, outros 15 projetos de novos estados brasileiros tramitam no legislativo federal - Araguaia, Aripuanã, Gurguéia, Juruá, Madeira, Marajó, Maranhão do Sul, Mato grosso do Norte, Norte de Minas, Rio Negro, São Francisco, São Paulo do Leste, Solimões, Uirapuru e Xingu (CIGOLINI, 2012) (figura 1.3-7)

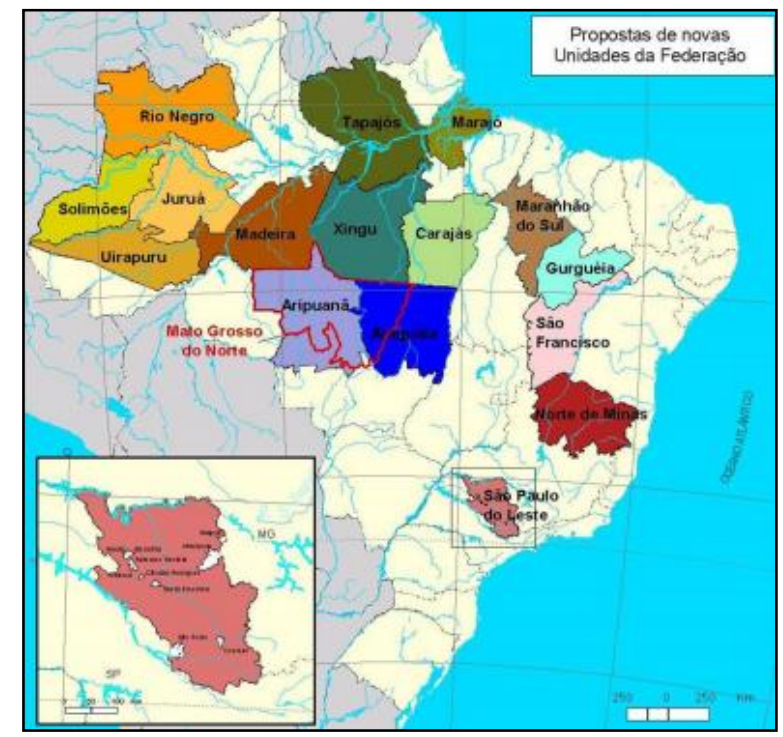

Figura 1.3-7 - Proposta de criação de novos estados em tramitação no legislativo federal Fonte: Cigolini (2012) 

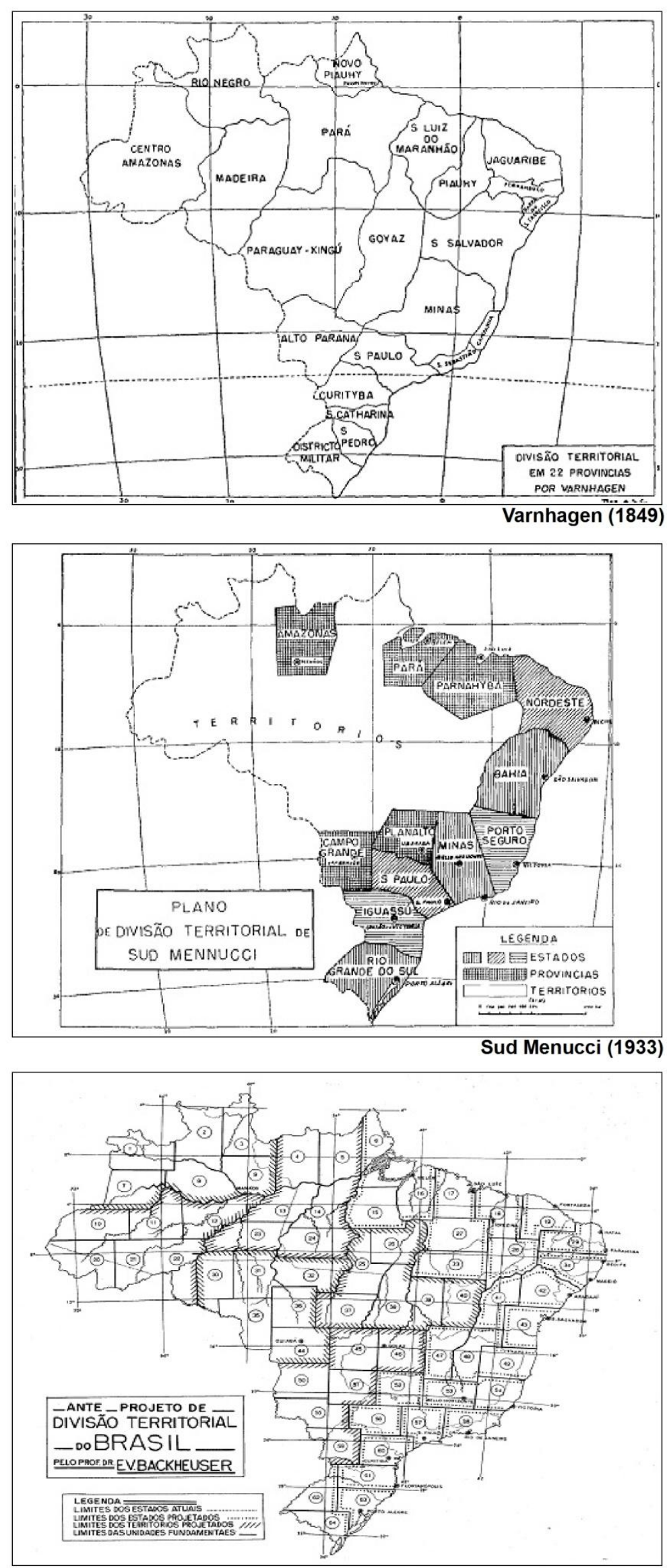

Everardo Backheuser (1933)
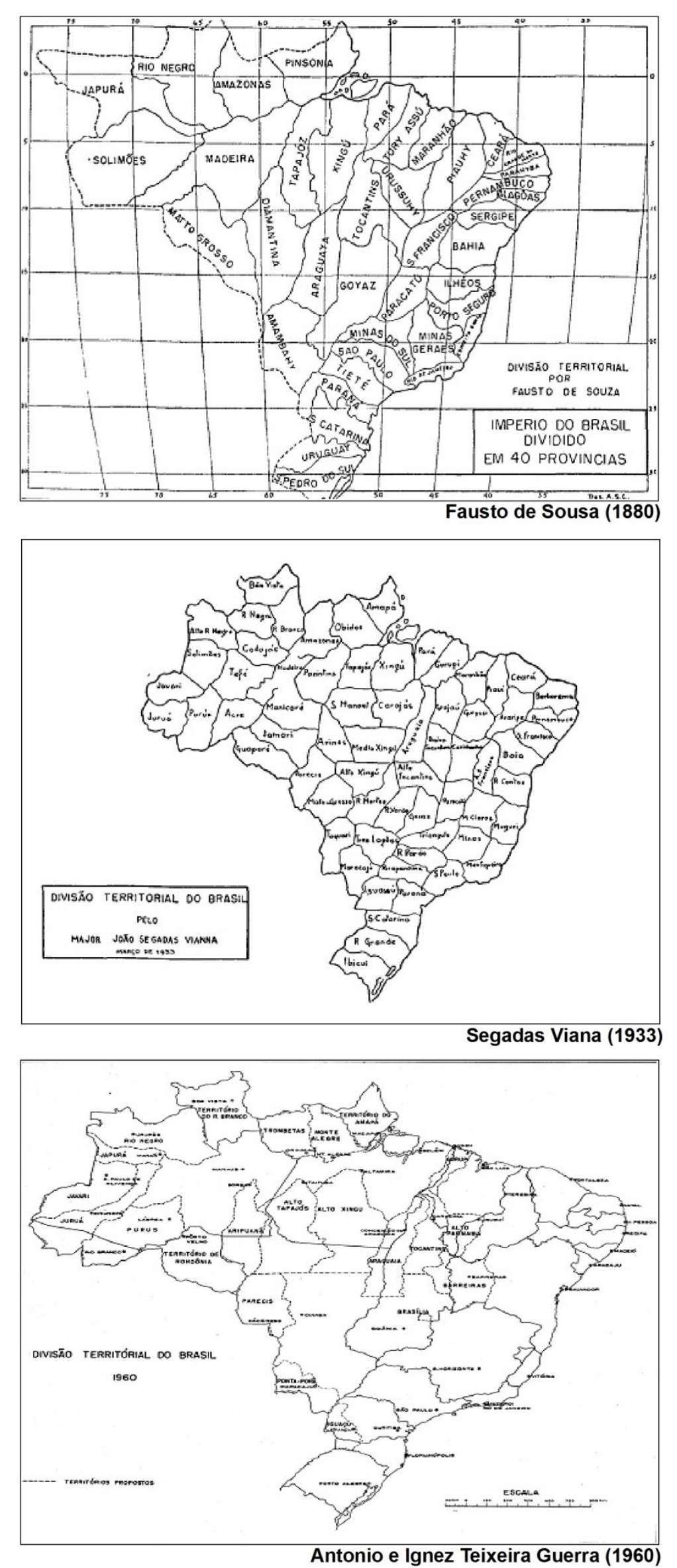
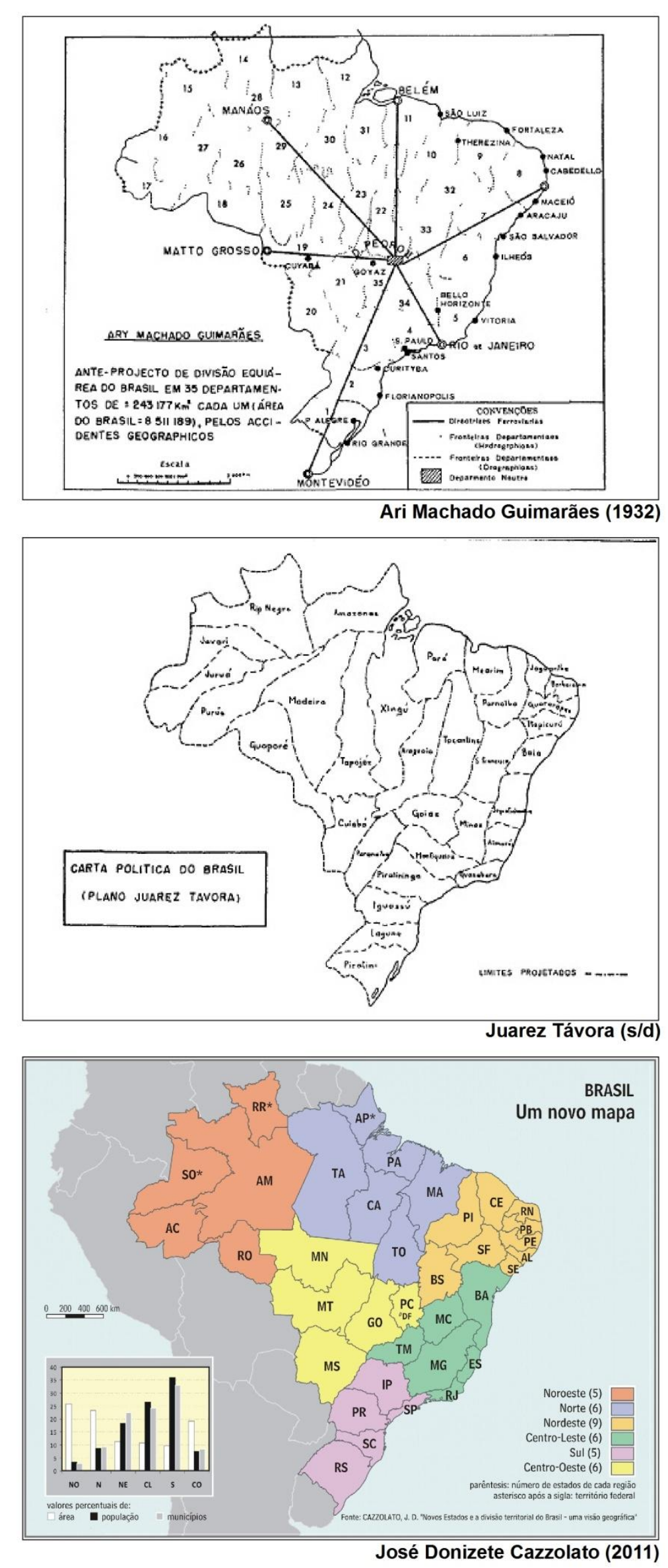

Figura 1.3-8 - Proposta de redivisão territorial do Brasil. Fonte: Guerra e Guerra (1960)/Cazzolato (2011) 
A análise do panorama municipal, por sua vez, revela uma menor estabilidade da malha territorial correspondente. Segundo o IBGE (2011), entre os anos de 1872 e 2010, o número de municípios brasileiros cresceu aproximadamente $800 \%$, indo de 642 para 5.565 (figura 1.3-9/gráfico 1.3-1). Como aponta Cigolini (2009), somente no período compreendido entre 1986 e 2008 foram criados 1.465 Municípios em todo território nacional, um aumento superior a 35\% em relação aos até então 4.102 municípios existentes (tabela 1.3-1). Neste período pode-se destacar o Rio Grande do Sul em quanto quantidade (238 municípios criados) e os estados do Amapá e de Rondônia em relação ao aumento percentual no número de territórios municipais (275\% e $218 \%$ respectivamente). Além disso, de acordo com levantamento feito em 2011 pela Confederação Nacional dos Municípios (CNM), existem aproximadamente 800 pedidos de emancipação de distritos ${ }^{3}$ protocolados nas assembleias legislativas estaduais. Novamente é possível notar que o período de maior intensificação da globalização coincidiu com um crescimento nos processos de repartição territorial.

Deve-se considerar que, ao refletir diretamente em questões econômicas e políticas, as fronteiras internas reafirmam sua importância e permanência mesmo dentro deste "mundo sem fronteiras". Desta forma, a produção de novos limites e de novos territórios, além da redefinição de outros, acontece de forma cada vez mais intensa. A própria transformação da fronteira zona, não formalizada, para a fronteira linha, descrita, delimitada e demarcada, ocorre justamente com o processo progressivo de intensificação do contato entre diversos grupos e núcleos humanos, do adensamento populacional e da valorização da terra (BACKHEUSER, 1952). Neste mesmo sentido, fenômenos atuais como a conurbação urbana, por exemplo, acarretam necessidades cada vez mais latentes de definições claras e precisas dos limites internos.

\footnotetext{
3 "São as unidades administrativas dos municípios. Têm sua criação norteadas pelas Leis Orgânicas dos Municípios." (IBGE, 1998)
} 

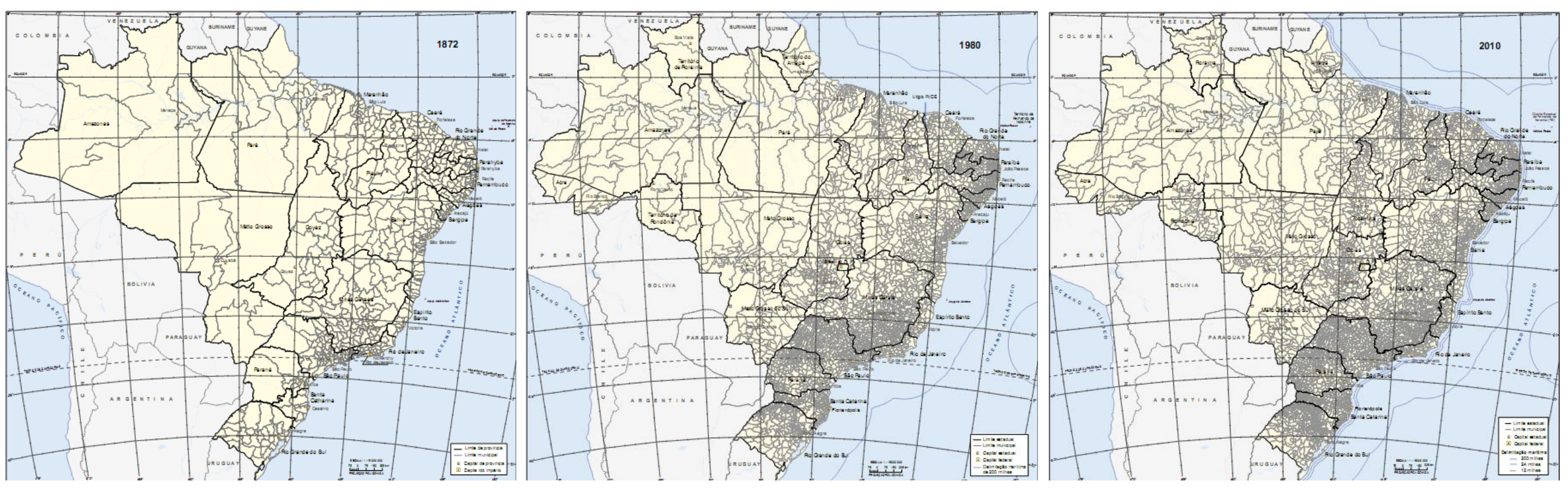

Figura 1.3-9 - Malha Municipal do Brasil nos anos de 1872 (esquerda), 1980 (centro) e 2010 (direita). Fonte: IBGE (2011) 


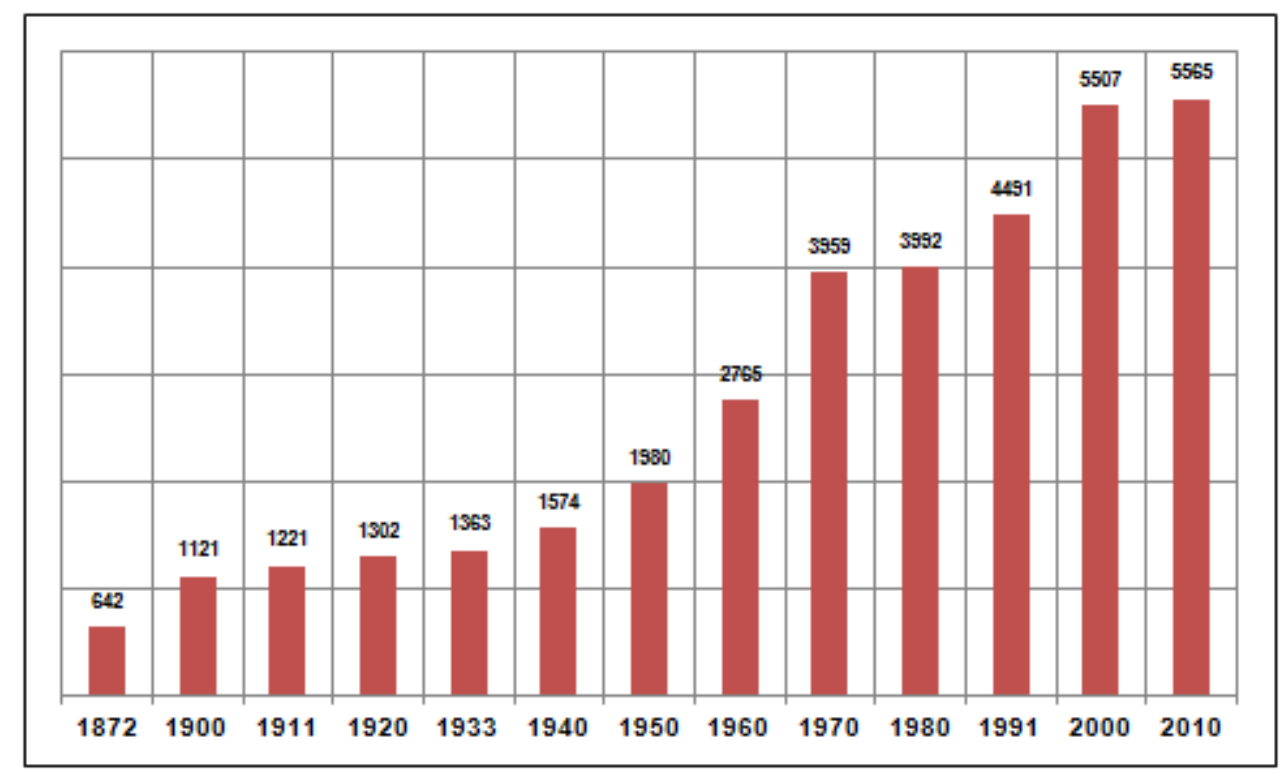

Gráfico 1.3-1 - Número de Municípios do Brasil - 1872-2010. Fonte: Adaptado de IBGE (2011)

Tabela 1.3-1 - Número de Municípios criados entre 1986 e 2008 no Brasil.

\begin{tabular}{|c|c|c|c|c|}
\hline Estado & Número de Municipios (1986) & Municípios criados no periodo & Número de Municipios (2008) & Crescimento sobre o total (\%) \\
\hline AC & 12 & 10 & 22 & 84 \\
\hline AL & 96 & 6 & 102 & 6 \\
\hline AM & 59 & 3 & 62 & 5 \\
\hline AP & 4 & 11 & 417 & 24 \\
\hline BA & 336 & 80 & 184 & 30 \\
\hline CE & 142 & 43 & 78 & 34 \\
\hline ES & 59 & 20 & 246 & 36 \\
\hline GO & 181 & 65 & 217 & 65 \\
\hline MA & 132 & 86 & 853 & 19 \\
\hline MG & 718 & 135 & 78 & 22 \\
\hline MS & 63 & 14 & 141 & 110 \\
\hline MT & 74 & 82 & 143 & 64 \\
\hline PA & 87 & 56 & 223 & 31 \\
\hline PB & 170 & 52 & 185 & 10 \\
\hline PE & 168 & 17 & 223 & 94 \\
\hline PI & 115 & 108 & 399 & 29 \\
\hline PR & 310 & 89 & 92 & 42 \\
\hline RJ & 65 & 27 & 167 & 11 \\
\hline RN & 151 & 17 & 52 & 218 \\
\hline RO & 17 & 37 & 15 & 87 \\
\hline RR & 8 & 7 & 496 & 103 \\
\hline RS & 244 & 252 & 293 & 47 \\
\hline SC & 199 & 94 & 75 & 1 \\
\hline SE & 74 & 1 & 645 & 13 \\
\hline SP & 573 & 73 & $\mathbf{5 5 6 3}$ & $\mathbf{3 6}$ \\
\hline TO & 59 & 1465 & & \\
\hline Total & 4102 & & 139 & \\
\hline & & 80 & & \\
\hline
\end{tabular}

Fonte: Adaptado de Cigolini (2009) 


\subsection{LIMITES INTERNOS E A DISTRIBUIÇÃO DE RECURSOS}

Como já apontado, o limite territorial interno pode influenciar diretamente em distintos elementos da administração pública e da vida social. Isto é um fato. Entretanto, considerando apenas as linhas de separação entre os municípios (elemento central deste estudo), pode-se identificar na questão da distribuição dos impostos e recursos um dos aspectos de maior relevância.

De acordo com Santim (2005), a promulgação da Constituição de 1988 diferenciou o federalismo brasileiro dos demais existentes no planeta no que tange a importância e ao papel do município. As unidades municipais deixavam de apresentar um caráter meramente administrativo - assim como acontecia no regime anterior, notadamente centralizador - para serem elevadas a entes federativos, assim como a União e os Estados, passando a gozar de uma autonomia administrativa, financeira e política.

Em meio à uma maior participação na divisão dos recursos com a União e os Estados, os municípios também foram contemplados com novas responsabilidades e atribuições, anteriormente atreladas exclusivamente às esferas federal e estadual. $O$ balanço entre estes dois elementos, entretanto, apresenta um desequilíbrio fortemente pendente para o segundo. A contestação desta pendência é recorrente nos trabalhos destinados a analisar os resultados pós-1988 para a administração municipal.

Não obstante a louvável intenção do legislador constituinte de transferir a prestação de determinados serviços para o Município, que, em última análise, é o ente político mais próximo do cidadão e conhecedor das realidades e necessidades locais, é de se verificar que não houve de maneira idêntica transferência de recursos correspondentes destinados ao atendimento dos mesmos serviços, o que está levando os Municípios a situações financeiras melindrosas. De igual sorte, houve também a transferência ao Município de responsabilidades nas áreas de saúde e trânsito, acarretando-Ihe gastos inesperados. (MELO FILHO, 1999)

Entretanto, o desmonte da máquina administrativa federal e também dos Estados, que notoriamente passam por dificuldades financeiras há muito tempo, fez com que os encargos municipais fossem ampliados em larga escala, tanto do ponto de vista quantitativo como qualitativo. Esta prática, que vem sendo adotada em todo o País, fez com que os Municípios tivessem uma elevação dos seus gastos muito acima dos recursos que lhes foram disponibilizados. (BREMAEKER, 1998) 
Se a questão dos recursos é problemática, o atual cenário de composição das receitas municipais é, sem dúvida, um agravante. Assim como apontam Solimeo e Gamboa (2012), a análise das receitas fiscais da totalidade dos municípios brasileiros evidencia a enorme dependência dos ingressos provenientes de transferências federais e estaduais, correspondentes a maior parte do "bolo tributário" na grande maioria dos casos (71,4\% em 2010). Em suma, além de faltar dinheiro nos cofres municipais para a oferta dos serviços públicos atribuídos, a maior parte não é arrecadada internamente.

Tabela 1.4-1 - Relação entre Receitas Fiscais e Receitas Correntes dos Municípios Brasileiros (19982010).

\begin{tabular}{|c|c|c|}
\hline Especificação & Participação - Receitas Correntes (1998) & Participação - Receitas Correntes (2010) \\
\hline 1. Receitas Correntes & $100,0 \%$ & $100,0 \%$ \\
\hline 1.1 Receitas Tributárias & $20,8 \%$ & $17,7 \%$ \\
\hline - Impostos & $16,3 \%$ & $16,3 \%$ \\
\hline IPTU & $6,4 \%$ & $4,3 \%$ \\
\hline ITBI & $1,5 \%$ & $1,6 \%$ \\
\hline ISS & $8,5 \%$ & $8,7 \%$ \\
\hline - Outras Taxas e Receitas Tributárias & $4,4 \%$ & $1,4 \%$ \\
\hline 1.2 Receitas de Transferência & $68,4 \%$ & $71,4 \%$ \\
\hline - Transferências da União & $33,1 \%$ & $31,6 \%$ \\
\hline Cota FPM & $19,5 \%$ & $18,3 \%$ \\
\hline Cota ITR & $0,2 \%$ & $0,2 \%$ \\
\hline SUS União & $4,6 \%$ & $8,6 \%$ \\
\hline Outras Transferências da União & $8,8 \%$ & $4,5 \%$ \\
\hline - Transferências do Estado & $33,5 \%$ & $24,0 \%$ \\
\hline Cota ICMS & $22,7 \%$ & $19,6 \%$ \\
\hline Cota IPVA & $3,4 \%$ & $3,0 \%$ \\
\hline Cota IPI Exportação & $0,5 \%$ & $0,3 \%$ \\
\hline Outras Transferências do Estado & $8,8 \%$ & $4,5 \%$ \\
\hline - Transferências do FUNDEP & $7,0 \%$ & $14,2 \%$ \\
\hline - Outras Transferências Correntes & $1,8 \%$ & $1,6 \%$ \\
\hline 1.3 Outras Receitas Correntes & $10,8 \%$ & $10,9 \%$ \\
\hline 2. Receitas de Capital & $9,4 \%$ & $5,0 \%$ \\
\hline - Transferências de Capital & $4,4 \%$ & $3,3 \%$ \\
\hline
\end{tabular}

Fonte: Adaptado de Solimeo e Gamboa (2012)

A partir dos dados apresentados no estudo dos referidos autores (tabela 1.41) é possível identificar, em meio a todas as transferências federais e estaduais, a preponderância das cotas do Fundo de Participação dos Municípios (FPM) e do Imposto sobre Circulação de Mercadorias e Serviços (ICMS), responsáveis por $18,3 \%$ e $19,6 \%$ do total das Receitas Correntes em 2010. Enquanto o primeiro, de origem federal, corresponde a $23,5 \%$ das receitas do Imposto de Renda (IR) e Imposto sobre Produtos Industrializados (IPI), o segundo, provenientes dos Estados, é correspondente a repartição de $25 \%$ da arrecadação do citado imposto (ARRETCHE, 2012). 
Centrando a análise na referida transferência estadual, quais seriam, então, os critérios para a composição da cota para cada município? É justamente neste ponto que podemos identificar o papel dos limites intermunicipais.

Segundo Garcia (2002), a legislação atual, pós-1988, acarretou em uma situação de grande quantidade de modelos para a distribuição do ICMS entre os municípios, apresentando diferenças e semelhanças dentro daqueles adotados por cada estado federado. Nestes, diversos indicadores de caráter social, econômico, histórico, cultural e ambiental podem ser encontrados (tabela 1.4-2).

Dentro deste contexto, torna-se possível identificar uma relação: a maioria dos critérios utilizados para a composição dos Índices de Participação dos Municípios (IPM) estaduais é proveniente de dados oficiais, produzidos e/ou extraídos de estudos e coletas desenvolvidos por órgãos estatais, sejam eles federais ou estaduais. A área cultivada por uma instituição ligada à agricultura, o número de propriedades por uma ligada a questão fundiária, a área inundada pelo órgão responsável pela gestão de águas e energia, a área de preservação pelo órgão ambiental, etc.

Se as fontes podem ser diversas, a essência, em contrapartida, é similar. Caso determinada pesquisa busque levantar o número de habitantes de determinado local, por exemplo, torna-se necessário, antes de qualquer coisa, que a área de estudo seja conhecida e delimitada. Logo, pode-se identificar na figura do território, uma espécie de "molde estatístico", a partir do qual grande parte dos dados coletados são agrupados e apresentados.

Segundo Azambuja (1976), o próprio Estado, para existir como tal, apresenta no território um de seus elementos indispensáveis (conjuntamente à população e ao governo), uma vez que o mesmo, enquanto sua base física, define a sua jurisdição e Ihe fornece recursos minerais. Mas se o molde territorial permite a existência do Estado (e de toda a sua hierarquia) e condiciona os levantamentos estatísticos deste, o mesmo é condicionado por seus limites, sem os quais também não existiria. Mesmo que a discussão do conceito na Geografia apresente variações, a consideração do território enquanto uma área espacialmente definida é praticamente unanime. 
O território envolve sempre, ao mesmo tempo, mas em diferentes graus de correspondência e intensidade, uma dimensão simbólico-cultural, através de uma identidade territorial atribuída pelos grupos sociais como forma de 'controle simbólico' sobre o espaço onde vivem (sendo, portanto, uma forma de apropriação) e uma dimensão mais concreta, de caráter político disciplinar: o domínio do espaço pela definição de limites ou fronteiras visando à disciplinarização dos indivíduos e o uso/controle dos recursos aí presentes. (HAESBAERT, 1997)

Território: 1. Área terrestre, seu espaço aéreo e mares vizinhos, organizados em um Estado soberano. 2. Espaço pertencente a algo, alguém ou alguma coisa, delimitado por fronteiras. (TEREZO, 2008)

Território é uma porção do espaço geográfico que coincide com a extensão espacial da jurisdição de um governo. (GOTTMANN, 2008)

As constantes dificuldades experimentadas pelos juristas demonstram a necessidade de se aceitar que o território é um conceito, e um conceito mutável. Como geógrafo, sinto que seja indispensável definir território como uma porção do espaço geográfico, ou seja, espaço concreto e acessível às atividades humanas. Como tal, o espaço geográfico é contínuo, porém repartido, limitado, ainda que em expansão, diversificado e organizado. $\mathrm{O}$ território é fruto de repartição e de organização. Tal como todas as unidades do espaço geográfico, ele deve ser, em teoria, limitado, embora seu formato possa ser modificado por expansão, encolhimento ou subdivisão. (GOTTMANN, 2008)

Retomando a conceituação já explicitada, por território entende-se aqui a formulação mais frequente entre os geógrafos: uma porção espacial denominada, delimitada e apropriada. (CAZZOLATO, 2011)

Em meio aos inúmeros parâmetros de cálculo expostos acima, tomemos como exemplo dois daqueles de maior ocorrência: a área geográfica (16 ocorrências) e o número de habitantes ou eleitores (19 ocorrências).

No primeiro caso, a relação não poderia ser mais intrínseca e nítida. A área geográfica nada mais é do que o próprio território municipal, ou seja, o espaço definido pelos limites intermunicipais, instituídos juridicamente, e a partir do qual se obtém um valor numérico de área, o qual pode ser utilizado com ou sem a sua proporção em relação à área estadual total.

Dentro do critério populacional, a importância do limite, apesar de não ser tão perceptível, também é crucial. Para o cálculo do número de habitantes ou eleitores, 
pode-se recorrer aos dados oriundos de censos demográficos nacionais, assim como aqueles realizados pelo IBGE a cada década, ou a projeções realizadas por órgãos estaduais mediante a utilização de técnicas estatísticas. Seja qual for a escolha, a utilização dos "moldes" são imprescindíveis. Novamente o território municipal, contornado por suas bordas, surge como elemento de definição. A população de determinado município nada mais é que a quantidade de pessoas residentes, ou cadastradas, no espaço compreendido entre os seus limites.

Mesmo que não tão aprofundada, a análise aqui intentada é suficiente para a constatação de um encadeamento lógico simples: os limites intermunicipais moldam as estatísticas oficiais, as quais definem a distribuição de boa parte dos impostos arrecadados. Assim sendo, a adoção de um limite incoerente com a realidade, seja na definição ou na identificação do mesmo, acarreta em dados estatísticos também incoerentes, os quais, por sua vez, orientam erroneamente a repartição dos recursos. Nesta balança, ao mesmo tempo em que um município recebe valores acima do necessário, outro acaba sendo "agraciado" com valores insuficientes.

Em um contexto já apresentado de falta de recursos, no fim, quem "paga o pato" é a população, principalmente os seus setores mais carentes, extremamente dependentes da oferta de serviços básicos de competência municipal. Eis uma realidade pouco discutida, mas de grande relevância.

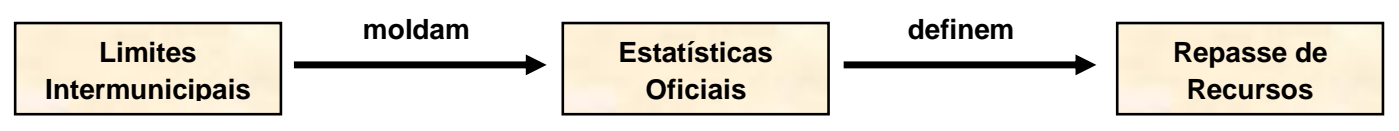

Figura 1.3-10 - Relação entre limites intermunicipais, estatísticas oficias e o repasse de recursos. Fonte: Elaborado pelo autor

Por fim, uma rápida consulta aos processos atualmente existentes na Comissão de Assuntos Metropolitanos e Municipais da Assembléia Legislativa do Estado de São Paulo (ALESP), referentes a pedidos de revisão de limites 
intermunicipais ou de emancipação política de distritos ou áreas, permite identificar a relação recursos-serviços como um elemento de argumentação recorrente. Citemos dois exemplos

Ressaltamos que o divisor atual (Ribeirão Marimbondo) separava 0 município de São Francisco do município de Jales e ficava muito distante da sede do mun. de São Francisco, por isso satisfazia os anseios da população de São Francisco, mas o fato é que com a criação do município de Dirce Reis e o município de Pontalinda, as divisas não foram revistas, o que vem causando enormes transtornos à população local e a Prefeitura de Dirce Reis, que pela proximidade do local a população dessa usufrui de todos os recursos provenientes de Dirce Reis e a arrecadação ficando com 0 município de Pontalinda. (Processo RGL 550 - 05/03/1999 - Solicitação de alteração das divisas entre os Municípios de Dirce Reis e Pontalinda)

...2- Os moradores desses Bairros dependem do Posto de Saúde, Escola de $1^{\circ}$ e $2^{\circ}$ graus, bem como, da Polícia Militar e Delegacia de Polícia do Município de Emilianópolis; 3- A manutenção de estradas de rodagem, pontes, e mata-burros existentes, bem como, outros serviços são feitos pela Prefeitura Municipal de Emilianópolis;...6- Todavia os impostos são recolhidos para o Município de Presidente Bernardes. (Processo RGL 227 19/02/1999 - Solicitação de alteração das divisas entre os Municípios de Emilianópolis e Presidente Bernardes) 
Tabela 1.4-2 - Critérios estaduais de distribuição do ICMS.

\begin{tabular}{|c|c|c|c|c|c|c|c|c|c|c|c|c|c|c|c|c|c|c|c|c|c|c|c|c|c|c|c|c|c|c|c|}
\hline \multicolumn{3}{|r|}{ Critério } & \multicolumn{4}{|c|}{ Sudeste } & \multicolumn{3}{|c|}{ Sul } & \multicolumn{9}{|c|}{ Nordeste } & \multicolumn{7}{|c|}{ Norte } & \multicolumn{3}{|c|}{\begin{tabular}{|l|} 
Centro-Oeste \\
\end{tabular}} & \multirow{2}{*}{ Soma } & \multirow{2}{*}{ Média } & \multirow{2}{*}{ Média do Grupo } \\
\hline Natureza & Setor & Espécie ou Parâmetro & SP & MG & RJ & ES & RS & $\mathrm{sc}$ & PR & $\mathrm{AL}$ & BA & $\mathrm{CE}$ & MA & \begin{tabular}{|l|l}
$\mathrm{PB}$ & 1 \\
\end{tabular} & PE & $\mathrm{PI}$ & \begin{tabular}{l|l}
$\mathrm{RN}$ & $\mathrm{s}$ \\
\end{tabular} & SE & AC & AM & AP & PA & RO 1 & RR & To & GO & \begin{tabular}{|l|l} 
MS \\
\end{tabular} & MT & & & \\
\hline \begin{tabular}{|l|} 
Origem da Receita \\
\end{tabular} & & İndice de Valor Adicionado & 76 & 79,7 & 75 & \begin{tabular}{|l|l|}
75 \\
\end{tabular} & 75 & 85 & \begin{tabular}{|l|l|}
75 \\
\end{tabular} & \begin{tabular}{|c|c|}
75 \\
\end{tabular} & \begin{tabular}{|l|l|}
75 \\
\end{tabular} & 75 & 75 & \begin{tabular}{l|l}
75 \\
\end{tabular} & 75 & 75 & $\begin{array}{lll}80 & 7 \\
\end{array}$ & \begin{tabular}{|l|l|}
75 \\
\end{tabular} & & 75 & 75 & \begin{tabular}{|l|l|}
75 \\
\end{tabular} & 75 & \begin{tabular}{|l|}
75 \\
\end{tabular} & \begin{tabular}{|l|}
85 \\
\end{tabular} & 90 & 75 & 75 & 1920,7 & 73,87 & 73,87 \\
\hline \multirow{2}{*}{ Demanda } & & População ou eleitores & 13 & 2,7 & 6,94 & & 7 & & & \begin{tabular}{|l|l}
5 \\
\end{tabular} & 10 & 5 & 5 & \begin{tabular}{|l|l}
5 \\
\end{tabular} & & 12,5 & 10 & & 100 & 7 & 2,6 & \begin{tabular}{|c|c|}
5 \\
\end{tabular} & \begin{tabular}{l|l|}
0,5 & \\
\end{tabular} & & 2,5 & & 5 & 2 & 206,74 & 7,95 & \multirow{2}{*}{8,12} \\
\hline & & Mais populosos & & 2 & & & & & & & & & & & & & & & & & 2,3 & & & & & & & & 4,3 & 0,17 & \\
\hline \multirow{4}{*}{ Compensação } & & Cota Fixa & 2 & 5,5 & 8,18 & & & 15 & \begin{tabular}{|l|}
2 \\
\end{tabular} & \begin{tabular}{l|l}
15 \\
\end{tabular} & 7,5 & 7,5 & 15 & 20 & & & \begin{tabular}{ll|l}
102 \\
10
\end{tabular} & 25 & & 15 & 7 & \begin{tabular}{|c|}
15 \\
\end{tabular} & 14 & \begin{tabular}{|l|}
25 \\
\end{tabular} & 10 & 10 & \begin{tabular}{|l|l|}
7 & $x$ \\
\end{tabular} & 9 & 244,68 & 9,41 & \multirow{4}{*}{13,16} \\
\hline & & Área Geográfica & & 1 & 7,7 & 5 & 7 & & 2 & 5 & \begin{tabular}{|l|l|}
7,5 \\
\end{tabular} & & 5 & & & 12,5 & & & & 3 & 1,1 & 5 & \begin{tabular}{l|l}
0,5 \\
\end{tabular} & & 2,5 & & 5 & 1 & 70,8 & 2,72 & \\
\hline & & Diferença Positiva & & & & & & & & & & & & & 25 & & & & & & & & & & & & & & 25 & 0,96 & \\
\hline & & İndice inverso de População, Área e Valor Adicionado & & & 1,73 & & & & & & & & & & & & & & & & & & & & & & & & 1,73 & 0,07 & \\
\hline \multirow{2}{*}{ Indução Financeira } & \multirow{2}{*}{ Receita Própria } & Proporção em relação ao conjunto de municipios & 5 & 2 & & & & & & & & & & & & & & & & & 2,6 & & & & & & 3 & 6 & 18,6 & 0,72 & \multirow{2}{*}{0,73} \\
\hline & & Razão em relação à receita de ICMS no mesmo municipio & & & 0,45 & & & & & & & & & & & & & & & & & & & & & & & & 0,45 & 0,02 & \\
\hline \multirow{21}{*}{ Indução Setorial } & & Área Cultivada & 3 & 0,5 & & & 5 & & 2 & & & & & & & & & & & & 1,4 & & & & & & & & 11,9 & 0,46 & \\
\hline & Agricultura & Número de propriedades & & 0,5 & & 7 & 3,5 & & 8 & & & & & & & & & & & & & & & & & & & & 19 & 0,73 & \\
\hline & & Valor da produção & & & & 6 & & & & & & & & & & & & & & & & & 5 & & & & & & 11 & 0,42 & \\
\hline & & Área de preservação (somente) & 0,5 & & & & & & & & & & & & & & & & & & & & 5 & & & & 5 & & 10,5 & 0,40 & \\
\hline & & Área inundada por hidrelétricas & 0,5 & & & & & & & & & & & & & & & & & & & & & & & & & & 0,5 & 0,02 & \\
\hline & & Área de preservação (área e qualidade) & & 0,5 & & & & & 2,5 & & & & & & & & & & & & 1,4 & & & & & & & 5 & 9,4 & 0,36 & \\
\hline & Ambiente & Mananciais (área e qualidade) & & & & & & & 2,5 & & & & & & & & & & & & & & & & & & & & 2,5 & 0,10 & \\
\hline & & Tratamento do lixo, esgoto e fornecimento de água & & & & & & & & & & & & & & & & & & & & & & & & & & 2 & 2 & 0,08 & \\
\hline & & Tratamento de lixo e esgoto & & 0,5 & & & & & & & & & & & & & & & & & & & & & & & & & 0,5 & 0,02 & \\
\hline & & Gasto setorial/receita corrente total & & & & & & & & & & 12,5 & & & & & & & & & & & & & & & & & 12,5 & 0,48 & \\
\hline & Educação & Percentual de matriculas & & 2 & & & & & & & & & & & & & & & & & 2,6 & & & & & & & & 4,6 & 0,18 & 4,12 \\
\hline & & İndice inverso de evasão escolar & & & & & 1 & & & & & & & & & & & & & & & & & & & & & & 1 & 0,04 & \\
\hline & & Gasto em saúde & & 1 & & 3 & & & & & & & & & & & & & & & & & & & & & & & 4 & 0,15 & \\
\hline & & Equipes e população atendida & & 1 & & & & & & & & & & & & & & & & & 2,6 & & & & & & & & 3,6 & 0,14 & \\
\hline & Saúde & Participação em consórcio de saúde & & & & 1 & & & & & & & & & & & & & & & & & & & & & & & 1 & 0,04 & \\
\hline & & Gestão avançada em saúde & & & & 3 & & & & & & & & & & & & & & & & & & & & & & & 3 & 0,12 & \\
\hline & & İndice inverso de mortalidade infantil & & & & & 1 & & & & & & & & & & & & & & & & & & & & & & 1 & 0,04 & \\
\hline & Cultura & Patrimônio histórico e cultural & & 1 & & & & & & & & & & & & & & & & & 1,4 & & & & & & & & 2,4 & 0,09 & \\
\hline & Indústria & Municipios mineradores & & 0,1 & & & & & & & & & & & & & & & & & 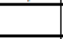 & & & & & & & & 0,1 & 0,00 & \\
\hline & & População Rural & & & & & & & 6 & & & & & & & & & & & & & & & & & & & & 6 & 0,23 & \\
\hline & Outros & Colaboração mútua & & & & & 0,5 & & & & & & & & & & & & & & & & & & & & & & 0,5 & 0,02 & \\
\hline & & Soma & 100 & 100 & 100 & \begin{tabular}{|l|}
100 \\
\end{tabular} & 100 & \begin{tabular}{|l|}
100 \\
\end{tabular} & \begin{tabular}{|l|l|}
100 \\
\end{tabular} & \begin{tabular}{|l|l}
100 \\
\end{tabular} & 100 & 100 & \begin{tabular}{|l|l}
100 & \\
\end{tabular} & \begin{tabular}{l|l}
100 & 1
\end{tabular} & 100 & 100 & \begin{tabular}{l|l}
100 & 1 \\
\end{tabular} & \begin{tabular}{|l|l}
100 & 1 \\
\end{tabular} & 100 & \begin{tabular}{|l|l|}
100 \\
\end{tabular} & 100 & \begin{tabular}{|l|}
100 \\
\end{tabular} & \begin{tabular}{l|l|l}
100 & 1
\end{tabular} & \begin{tabular}{|l|l}
100 & 1 \\
\end{tabular} & \begin{tabular}{|l|l|}
100 \\
\end{tabular} & \begin{tabular}{|l|}
100 \\
\end{tabular} & \begin{tabular}{l|l}
100 & 1 \\
\end{tabular} & 100 & 2600 & 100 & 100 \\
\hline
\end{tabular}

Fonte: Adaptado de Barros apud Garcia (2002) 


\section{ANÁLISE DA DELIMITACÃO TERRITORIAL DE MUNICÍPIOS NO BRASIL - LEGISLACC̃̃O E TENDÊNCIAS}

Como foi intentando demonstrar no capítulo anterior, os limites territoriais internos apresentam um papel de grande relevância na organização territorial e administrativa do país, o qual é muitas vezes despercebido e desconsiderado em ambientes políticos, técnicos e acadêmicos. Dentro disto, antes mesmo de qualquer tipo de discussão ou proposição de modelos ou métodos para a delimitação territorial de municípios, faz-se necessário verificar de que forma este tipo de procedimento ocorre no Brasil.

É imprescindível, em um primeiro momento, direcionar o foco de estudo para o aspecto legal envolvido, ou seja, para a verificação das orientações jurídicas correlatas existentes na atualidade como também para aquelas que nortearam a temática ao longo do tempo no território nacional. Existem ou existiram parâmetros claros e coerentes, juridicamente estabelecidos, para a proposição dos limites municipais? Eis a pergunta central deste capítulo.

\subsection{ASPECTOS LEGAIS - BREVE HISTÓRICO}

A figura do município, surgida em Roma e implantada no Brasil pela administração portuguesa, apesar de ter sido alçada a um patamar de considerável importância a partir da Constituição de 1988, apresentou grandes variações em seu papel dentro da federação ao longo do tempo. Passando de momentos predominantes de uma restrita autonomia, para alguns lapsos de maiores liberdades administrativas, políticas e econômicas, o município esteve no bojo do jogo político entre o poder central e os interesses regionais e locais. É em meio a este embate que a malha municipal brasileira pode ser analisada.

Considerando as três primeiras constituições do país (1824, 1891 e 1934), a busca por qualquer tipo de orientação legal para a criação e delimitação de 
municípios apresenta um resultado nulo, sendo promulgadas, neste período, apenas leis referentes à eleição e as atribuições das câmaras municipais. Em suma, os 1.363 municípios existentes até então - considerando os dados do IBGE para o ano de 1933 - seriam territorialmente definidos em meio a uma total inexistência de regulamentação ou de parâmetros legais.

Neste cenário, um panorama conciso da malha municipal da época pode ser encontrada na exposição dirigida, em 1937, pelo presidente do recém-criado Instituto Nacional de Estatística ao presidente da República (Getúlio Vargas) ${ }^{4}$. Segundo José Carlos de Macedo Soares, o país não possuía parâmetros racionais de orientação para a divisão judiciária e administrativa do seu território, sendo caracterizado pela desordem e por numerosas anomalias em seu quadro territorial, o que, por sua vez, acarretava em grandes dificuldades administrativas e estatísticas. Quatro fatores seriam elencados na referida análise:

1. Falta absoluta de delimitação;

2. Delimitação defeituosa - porque variável ou inverificável - por divisas de terras particulares ou de circunscrições eclesiásticas antiquíssimas;

3. Configuração absurda, em face das condições geográficas;

4. Extra-territorialidade, ora pela não contiguidade das "sub-circunscrições" componentes, ora pela jurisdição sobre fazendas ou povoados "encravados" em outras circunscrições.

A situação começaria a mudar a partir do Decreto-Lei no 311 de 1938, o qual pode ser identificado enquanto o ponto de ruptura da ausência de normatização vigente até então. O mesmo, além de definir e hierarquizar termos como cidade, vila, distrito, termo judiciário e comarca, de prever a revisão do quadro territorial municipal em períodos quinquenais, e de impor uma quantidade mínima de moradores/residência necessárias para a instalação de distritos e municípios, tornou obrigatório a elaboração do mapa municipal de todos os municípios existentes e para todos aqueles que viessem a ser criados. Em relação à delimitação do território, o Artigo 8ำ previa que:

Os limites inter-distritais ou inter-municipais serão definidos segundo linhas geodésicas entre pontos bem identificados ou acompanhando acidentes naturais, não se admitindo linhas divisórias sem definição expressa ou caracterizadas apenas pela coincidência com divisas pretéritas ou atuais.

\footnotetext{
${ }^{4}$ Publicado na Revista Brasileira de Geografia, Vol. 1, n² 1939.
} 
Desta forma, além de considerar a direta e essencial relação entre a divisão do território e a cartografia, o Decreto-Lei o 311 de 1938, ao determinar a adoção de linhas geodésicas entre pontos bem identificados ou acidentes naturais para a caracterização das futuras divisas, "ditaria" uma tendência presente até os dias atuais. Delimitações imprecisas e vagas, impregnadas de elementos particulares, dariam lugar a descrições mais elaboradas e menos confusas. Como caso de exemplificação, consideremos as distintas descrições da díade entre os municípios paulistas de Pindamonhangaba e Taubaté presentes em uma legislação pré e pósdecreto.

\section{Lei Estadual no 4, de 22 de março de 1851}

Art. 1. - A divisa entre os municípios de Pindamonhangaba e Taubaté será d'ora em diante: A ponte do Rio Pyracoama, junto á casa de Francisco Pires, d'aqui seguindo pela estrada até a casa de Francisco Antunes, e d'este ultimo ponto á rumo ao espigão do lado esquerdo da estrada, d'onde seguirá uma linha recta ao alto da Serra.

\section{Decreto Estadual no 9.775, de 30 de novembro de 1938}

O município de Pindamonhangaba, comarca do mesmo nome, terá as seguintes divisas:

Com o Município de Taubaté:

Começam na Serra Quebra Cangalha, no ponto onde cruza com o divisor das águas do ribeirão Turvo, à esquerda, e ribeirão das Almas, à direita, seguem pelo espigão que deixa, à direita, as águas do rio Paraíba, e, à esquerda as das vertentes do rio Una, passando pelos morros Matacacheta e Grande, em demanda da barra do primeiro córrego que desemboca na margem direita do rio Una, logo abaixo da foz do córrego Ipiranga e pelo Una abaixo seguem ate a barra do córrego do Mata-Fome nas proximidades do bairro do mesmo nome.

As duas constituições federais subsequentes não apresentariam grandes modificações ou incorporações na temática dos limites internos. Enquanto a Constituição de 1946, apesar de conceder maior autonomia ao município, não continha nenhum tipo de especificação no que tange a suas linhas limítrofes, a Constituição de 1967, centralizadora, mediante a Lei Complementar № 1 do mesmo ano, além de tornar o processo de criação de municípios mais complexo através da inserção de novos pré-requisitos (plebiscito, por exemplo), retomava e simplificava em seu Artigo 8ํaㄹ aquele de mesmo número do Decreto-Lei de 1938 ao determinar 
que "A Lei que criar o novo Município definirá seus limites segundo linhas geodésicas entre pontos bem identificados ou acompanhando acidentes naturais."

A Constituição de 1988, por sua vez, em meio a sua orientação descentralizadora, transferiria a competência de criação de municípios, e de seus respectivos critérios, aos estados componentes da federação.

\section{Constituição Federal de 1988}

\section{Artigo 18}

§ 4 A criação, a incorporação, a fusão e o desmembramento de Municípios preservarão a continuidade e a unidade histórico-cultural do ambiente urbano, far-se-ão por lei estadual, obedecidos os requisitos previstos em Lei Complementar estadual, e dependerão de consulta prévia, mediante plebiscito, às populações diretamente interessadas.

Neste contexto, o estabelecimento de limites intermunicipais passaria a estar atrelado a leis estaduais sancionadas nos anos subsequentes, as quais apresentariam elementos muitas vezes correspondentes, além de algumas particularidades $^{5}$. Apresentemos o levantamento das partes correspondentes das mesmas $^{6}$ :

\section{Acre}

\section{Lei Complementar $n^{\circ}$ 35, de 18 de dezembro de 1991}

\section{Capítulo V}

Art. 18. Na fixação dos limites municipais e das divisas distritais, serão observadas as seguintes normas:

I - o Município e o Distrito deverão ter configuração regular evitando-se, quanto possível, formas anômalas, estrangulamentos e alongamentos exagerados;

II - dar-se-á preferência, para a delimitação, às linhas naturais facilmente reconhecíveis;

III - na inexistência de linhas naturais, utilizar-se-á linha reta, cujos extremos sejam pontos naturais ou não, facilmente reconhecíveis e dotados de condições de fixidez; e

IV - na definição das divisas de novos Municípios, o órgão técnico competente do Estado, para aproveitar os acidentes naturais, deslocará a linha divisória até trezentos metros entre o Município desmembrado e o novo, desde que não acarrete para aquele prejuízo financeiro apreciável.

\footnotetext{
${ }^{5}$ Além do Distrito Federal, que não é subdivido em municípios, não foram encontradas leis para os estados do Maranhão, Piauí e Rio Grande do Norte.

${ }^{6}$ Foram consideradas apenas as últimas leis correlatas promulgadas em cada estado.
} 
Parágrafo único. A descrição sistemática dos limites municipais observará os seguintes procedimentos:

I - os limites de cada Município serão descritivos integralmente no sentido da marcha dos ponteiros do relógio e a partir do ponto mais ocidental de conformidade ao Norte;

II - as divisas distritais de cada Município serão descritas trecho a trecho, Distrito a Distrito, salvo, para evitar duplicidade, nos trechos que coincidirem com os limites municipais; e

III - na descrição dos limites municipais e das divisas distritais será usada linguagem apropriada, simples, clara e precisa.

\section{Alagoas}

Lei Complementar n 1, de 27 de março de 1990

Art. 6o - A Assembléia Legislativa Estadual, por maioria de 2/3 (dois terços), e mediante proposta da $8^{a}$ Comissão de Administração Pública, Segurança, Relação do Trabalho e Assuntos Municipais, definirá limites circunstanciais do Município a ser criado, incorporado ou fundido, obedecendo, preferencialmente, acidentes topográficos facilmente identificáveis ou linhas geodésicas, eliminando-se o uso de limites em definição expressa ou caracterizados apenas pela coincidência de divisas já existentes, evitandose, desta forma, a ocorrência de superposições ou vazios de áreas.

\section{Amapá}

\section{Constituição Estadual de 1991}

\section{Seção V}

\section{Art. 35}

§ 2ㅇ - O projeto de criação, incorporação, fusão e desmembramento de Municípios apresentará a área da unidade proposta em divisas claras, precisas e contínuas.

\section{Amazonas}

Lei Complementar n 7, de 29 de julho de 1991

Art. 8 - A Lei que criar o novo Município definirá seus limites segundo linhas geodésicas entre pontos bem identificados ou acompanhando acidentes naturais.

\section{Bahia}

Lei Complementar no 002, de 4 de maio de 1990

Art. 13 - Na fixação dos limites municipais e das divisas distritais, serão observadas as seguintes normas:

I - o Município e o Distrito deverão ter configuração regular, evitando-se quando possível, formas anômalas, estrangulamentos e alongamentos exagerados;

II - dar-se-á preferência para delimitação às linhas naturais, facilmente reconhecíveis; 
III - na inexistência de linhas naturais, utilizar-se-ão linhas retas cujos extremos sejam pontos naturais ou facilmente reconhecíveis e dotados de condições de fixidez.

Parágrafo único - A descrição dos limites municipais e divisas distritais, obedecerá ao seguinte:

I - os limites de cada Município serão descritos integralmente no sentido da marcha dos ponteiros do relógio e a partir do ponto mais ocidental da confrontação ao norte;

II - as divisas distritais de cada Município serão descritas trecho a trecho, distrito a distrito, salvo, para evitar duplicidade, nos trechos que coincidem com os limites municipais;

III - na descrição dos limites municipais e das divisas distritais, será usada linguagem apropriada, simples, clara e precisa.

\section{Ceará}

\section{Lei Complementar no 01, de 5 de novembro de 1991}

Art. $9^{\circ}$ - Do projeto de criação de município deverá constar memorial descritivo acompanhado de sua respectiva representação cartográfica.

\section{Espírito Santo}

\section{Lei Complementar no 146, de 4 de maio de 1999}

Art. 18. Para estabelecer limites territoriais, a Assembléia Legislativa deve solicitar ao órgão específico do Poder Executivo, a definição dos limites intermunicipais e distritais, a ser efetivada no prazo improrrogável de vinte dias úteis.

§ 1 $\mathrm{Na}$ definição dos limites devem ser observadas as seguintes coordenadas:

I - os limites descritos, no sentido da marcha dos ponteiros do relógio a partir do ponto mais ocidental de confrontação, ao norte;

II - as divisas distritais descritas, distrito a distrito, exceção feita para os trechos que coincidirem como os limites municipais, para evitar publicidade;

III - os limites descritos com o uso de linguagem apropriada, simples, clara e precisa;

IV - as divisas baseadas, sempre que possível, em acidentes geográficos permanentes e facilmente identificáveis.

§ 20 Para aproveitar acidentes geográficos permanentes, a linha divisória pode ser deslocada até duzentos metros entre o Município desmembrado e o novo, desde que não acarrete a este prejuízo financeiro apreciável.

§ 3ํㅡㄹ Deslocando-se a linha divisória, nos termos do parágrafo anterior, e havendo mais de 100 (cem) moradores na faixa de terreno acrescida, deve ser realizada consulta plebiscitária posterior à demarcação da linha, cujo resultado importará tão somente na alteração ou não do limite.

\section{Goiás}

Lei Complementar n ${ }^{4}$, de 04 de julho de 1990

Art. $3^{\circ}$ - A lei de criação de município conterá os seguintes elementos: II - os limites municipais definidos, tanto quanto possível, segundo linhas geodésicas entre pontos bem identificados ou acompanhados de acidentes naturais; 
III - a configuração do município deverá, na medida do possível, obedecer a uma relativa harmonia, evitando-se formas anacrônicas, divisão de comunidades, exagerados estrangulamentos ou alargamentos;

IV - na impossibilidade de estabelecer linhas naturais, será utilizada a linha reta e seca, cujos extremos devem ser pontos facilmente identificáveis;

Art. $4^{\circ}$ - São requisitos para a criação de município, reduzidos a 2/3 no caso de municípios de interesse ecológico turístico ou especial interesse econômico, os dos itens, IV, V e VI;

II - apresentar solução de continuidade de, pelo menos, seis quilômetros entre a linha de divisa do novo Município e o perímetro urbano do município de origem;

III - não interromper a continuidade territorial do município de origem;

\section{Mato Grosso}

\section{Lei Complementar $n^{\circ}$ 23, de 19 de novembro de 1992}

Art. 20 São requisitos indispensáveis à criação de municípios, dentre outros: VI - apresentação de mapa e memorial descritivo de forma a demonstrar a manutenção ou a caracterização da continuidade territorial do município de origem e do município em via de criação.

Art. 5 A lei que criar o novo município definirá seus limites, acompanhando tanto quanto possível acidentes naturais e linhas geodésica claras, precisas e contínuas entre pontos bem identificados.

\section{Mato Grosso do Sul}

Lei Complementar $n^{\circ}$ 058, de 14 de janeiro de 1991

Art. $3^{\circ}$ Além das previstas na Constituição Estadual e nesta Lei Complementar, são condições para que o território se constitua em Município:

II - não interromper a continuidade territorial do Município ou Municípios de origem;

III - apresentar soluções de continuidade de dez quilômetros, no mínimo, entre o seu perímetro urbano e o Município de origem e não pertencente, em mais de trinta por cento a uma só pessoa física ou jurídica.

Parágrafo único. As superfícies de água fluvial ou lacustre não interrompem a continuidade territorial de que trata o inciso III deste artigo.

Art. $5^{\circ} \mathrm{A}$ descrição e fixação dos limites municipais e distritais e das divisas distritais observará os seguintes procedimentos:

I - os limites de cada município e Distrito serão descritos integralmente, no sentido da marcha dos ponteiros do relógio, a partir do ponto mais ocidental de confrontação ao norte;

II - as divisas distritais serão descritas trecho a trecho, Distrito a Distrito, para evitar duplicidade nos trechos que coincidirem com os limites municipais;

III - evitar-se-ão, tanto quanto possível, formas assimétricas, estrangulamentos por acidentes geográficos e alongamentos exagerados;

IV - dar-se-á preferência, para a delimitação, às linhas naturais, facilmente identificáveis;

V - na inexistência de linhas naturais, utilizar-se-á linha, cujos extremos, pontos naturais ou não, sejam facilmente identificáveis e tenham condições de fixidez. 


\section{Minas Gerais}

Lei Complementar no 37, de 18 de janeiro de 1995

Art. 9 - A Lei de criação de município mencionará a comarca a que pertence 0 novo município e definirá seus limites segundo linhas geográficas que acompanhem, preferencialmente, acidentes naturais e que se situem entre pontos de presumível permanência no terreno e identificáveis em documentação cartográfica oficial, sendo vedada a formação de áreas descontínuas.

\section{Pará}

Lei Complementar $n^{\circ}$ 001, de 18 janeiro de 1990

Art. $8^{\circ}$ - O resultado do plebiscito sendo favorável, a Assembléia Legislativa votará a lei de criação do novo Município, que mencionará:

II - os limites territoriais do Município, definidos em linhas geodésicas entre pontos bem identificados ou acompanhando acidentes naturais;

Paraíba

Lei Complementar $n^{\circ}$ 24, de 12 abril de 1996

Art. $6^{\circ}$ - A Lei de criação do Município mencionará:

II - As divisas, que deverão ser claras, precisas, contínuas, e sempre que possível acompanharão acidentes geográficos permanentes e facilmente identificáveis.

Paraná

Emenda Constitucional no 7, de 24 de abril de 2000

Art. 19. Lei complementar estadual disporá sobre a criação, a incorporação, a fusão e o desmembramento de Municípios.

§ 1‥ Os seguintes requisitos serão observados na criação de Município:

IV - não-constituição de área encravada no Município de origem.

§ 3‥ O projeto de criação, incorporação, fusão e desmembramento de Municípios apresentará a área da unidade proposta em divisas claras, precisas e contínuas.

\section{Pernambuco}

Lei Complementar no 1, de 12 de Julho de 1990/ Lei Complementar no 14, de 25 de Maio de 1995

§ 60 O distrito a ser emancipado deverá guardar a distância, mínima, de cinco (05), quilômetros da sede do município de origem;

§ $7^{\circ} \mathrm{O}$ território do novo município emancipado será o mesmo do distrito ou distritos e que sua população tenha participado do plebiscito;

Art. 8 A Lei que criar municípios mencionará:

II - os limites, segundo linhas geodésicas entre pontos bem identificados ou acompanhados dos acidentes naturais. 


\section{Rio de Janeiro}

Lei Complementar no 59, de 22 de fevereiro de 1990

Art. 4 - Além dos requisitos fixados no artigo anterior, são ainda condições para que um território se constitua em município.

V - O Município a ser criado terá de manter divisas com pelo menos dois Municípios, incluindo o de origem, ficando dispensadas desta exigência as áreas que, por sua conformação geográfica de cabos e penínsulas, não as possam manter.

Art. 12 - Na fixação dos limites municipais serão observadas as seguintes normas:

I - dar-se-á preferência, para a delimitação, às linha naturais, facilmente reconhecíveis e dotados de condições de fixidez.

\section{Rio Grande do Sul}

Lei Complementar no 13.535, de 5 de novembro de 2010

Art. 19. Na descrição dos limites intermunicipais ou interdistritais serão observadas as seguintes normas:

I - as superfícies de água não quebram a continuidade territorial;

II - a configuração do município deverá, na medida do possível, obedecer a uma relativa harmonia, evitando-se formas anômalas, exagerados estrangulamentos ou alargamentos;

III - na impossibilidade de estabelecer linhas naturais, será utilizada a linha reta e seca, cujos extremos devem ser pontos facilmente identificáveis;

IV - na criação de novo município, observar-se-á, na medida do possível, limites distritais já existentes, evitando-se a divisão de comunidades ou povoados;

V - as divisas serão descritas no sentido horário, a partir do ponto mais ocidental da confrontação norte.

\section{Rondônia}

\section{Lei Complementar n 31, de 10 de janeiro de 1990}

Art. 8. A Lei que criar, desmembrar, fundir e incorporar municípios definirá seus limites segundo linhas geodésicas entre pontos bem identificados ou acompanhando acidentes naturais, além de observar as seguintes descrições:

- não interromper a continuidade territorial e a unidade histórico-cultural do município de origem;

- delimitação da área da unidade proposta, através de divisas claras, precisas e contínuas, após prévia consulta ao órgão geográfico e geológico competente, existente no Estado.

\section{Roraima}

Lei Complementar no 001, de 11 de abril de 1992

Art. 16. Na descrição dos limites intermunicipais serão observadas as seguintes normas:

a) as superfícies de águas não quebram a continuidade territorial; 
b) a configuração do Município deverá, na medida do possível, obedecer a uma relativa harmonia, evitando-se formas anômalas, exageradas, estrangulamentos ou alargamentos;

c) na impossibilidade de estabelecer linhas naturais, será utilizada a linha reta e seca, cujos extremos devem ser pontos facilmente identificáveis;

d) na criação de novo Município, observar-se á, na medida do possível, limites distritais já existentes, evitando-se a divisão de comunidades ou povoados; e

e) as divisas serão descritas no sentido horário, a partir do ponto mais ocidental da confrontação norte.

\section{Santa Catarina}

\section{Lei Complementar no 135, de 11 de janeiro de 1995}

§ 1 음õo será criado Município se esta medida implicar:

d) em uma distância menor que 05 (cinco) quilômetros, pela rodovia principal, entre a sede do distrito emancipando e o perímetro urbano da sede do Município de origem ou outro Município próximo.

§ 2 을 Considere-se por sede do distrito emancipando, prevista na letra "d" do $\S 1^{\circ}$ deste artigo, o prédio da intendência distrital, ou, na falta deste, aquele destinado à instalação da Prefeitura Municipal.

Art. 19. As divisas do Município serão claras, precisas e contínuas e, sempre que possível, acompanharão acidentes geográficos naturais, facilmente identificáveis e sua elaboração dependerá de parecer da Secretaria de Estado do Planejamento e Fazenda, observando o que dispuser a lei.

Art. 20. Na descrição dos limites intermunicipais ou interdistritais serão observadas as seguintes normas:

I - as superfícies de água não quebram a continuidade territorial;

II - a configuração do Município deverá, na medida do possível, obedecer a uma relativa harmonia, evitando-se formas anômalas, exagerados estrangulamentos ou alargamentos;

III - na impossibilidade de estabelecer linhas naturais, será utilizada a linha reta e seca, cujos extremos devem ser pontos facilmente identificáveis:

IV - na criação de novo município, observar-se-á, sempre que possível, limites distritais já existentes, evitando-se a divisão de comunidades ou povoados, bem como de setores censitários;

V - as divisas serão descritas no sentido horário, a partir do ponto mais ocidental da confrontação norte.

\section{São Paulo}

\section{Lei Complementar no 651, de 31 de julho de 1990}

Artigo 2.ㅇ - Previamente ao plebiscito mencionado no artigo anterior, são condições indispensáveis e cumulativas para a criação de Município:

I - ser Distrito há mais de 2 (dois) anos;

IV - apresentar solução de continuidade de três quilômetros, no mínimo, entre o seu perímetro urbano, definido pelo competente órgão técnico do Estado e do Município de origem, excetuando-se os Distritos integrantes de Regiões Metropolitanas ou aglomerados urbanos;

V - não interromper a continuidade territorial do Município de origem, bem como preservar a continuidade e a unidade histórico-cultural do ambiente urbano, ouvido o competente órgão técnico do Estado.

Artigo 3.- - A lei de criação de Municípios mencionará:

II - as divisas; 
§ 2.․ - As divisas do novo Município serão definidas pelo órgão técnico competente do Estado, preferencialmente acompanhando acidentes naturais ou segundo linhas geodésicas entre pontos bem identificados.

§ 3. - Para aproveitar os acidentes naturais, deslocar-se-á linha divisória até duzentos metros entre o Município desmembrado e o novo, desde que não acarrete a este prejuízo financeiro apreciável.

§ 4.․ - Deslocando-se a linha divisória, nos termos, do parágrafo anterior, e havendo mais de cem moradores na faixa de terreno acrescida, será realizada consulta plebiscitária posterior à demarcação da linha, cujo resultado não terá influência no plebiscito anteriormente realizado no território já emancipado.

\section{Sergipe}

Lei Complementar no 01, de 9 de abril de 1990

Artigo 8 - A Lei que criar novo Município estabelecerá seus limites por pontos bem definidos, acompanhando acidentes naturais, sempre que possível.

\section{Tocantins}

Lei Complementar no 009, de 19 de dezembro de 1995

Art. 6․ São requisitos mínimos para a criação ou o desmembramento de Município:

V - ter o seu limite divisório a, pelo menos, cinco quilômetros da sede do Município de origem.

O período de autonomia estadual para a criação e delimitação de municípios, entretanto, duraria menos de uma década. Devido ao crescimento desenfreado no número de municípios após a promulgação da Constituição de 1988, muitos dos quais caracterizados por um número irrisório de habitantes e por receitas próprias insuficientes, caberia ao legislativo federal "retomar as rédeas" de todo o processo, sendo sancionada, para isso, a Emenda Constitucional oㅜ 15, de 12 de setembro de 1996. Embora tenha sido mantida a responsabilidade dos estados para a criação de municípios, agora os mesmos dependeriam de uma regulamentação por uma lei complementar federal, bem como da viabilização de Estudos de Viabilidade Municipal para cada caso ${ }^{7}$. Nos termos da lei:

\footnotetext{
${ }^{7}$ Devido a indefinição ocasionada pela inexistência da referida lei complementar federal, os estados do Espírito Santo, Paraná e Rio Grande do Sul acabaram promulgando leis em período posterior a Emenda Constitucional, vide o levantamento dos dispositivos legais estaduais apresentado acima.
} 
§ 4 A criação, a incorporação, a fusão e o desmembramento de Municípios, far-se-ão por lei estadual, dentro do período determinado por lei complementar federal, e dependerão de consulta prévia, mediante plebiscito, às populações dos Municípios envolvidos, após divulgação dos Estudos de Viabilidade Municipal, apresentados e publicados na forma da lei.

Após quase duas décadas, nota-se uma situação de total indefinição, uma vez que a referida lei complementar federal ainda inexiste. Apesar disto, podem ser identificadas, no ambiente político, algumas proposições reais para a solução da lacuna criada. São elas: Projeto de Lei do Senado № 98 de 2002; Projeto de Lei do Senado ํo 503 de 2003; Projeto de Lei do Senado o 60 de 2008; Projeto de Lei da Câmara no 293 de 2008; Projeto de Lei do Senado no 96 de 2008; Projeto de Lei do Senado no 197 de 2011; o Projeto de Lei do Senado no 104 de 2014.

De uma forma geral, no que tange aos limites territoriais, nenhuma mudança substancial aparece em meio aos textos dos referidos projetos, havendo basicamente a repetição de orientações já apresentadas em leis anteriores, salvo o Projeto de Lei do Senado oo 104 de 2014. Este, além de definir critérios populacionais fixos para a criação de municípios em cada uma das regiões brasileiras e de confirmar obrigatoriedade dos Estudos de Viabilidade Municipal, apresenta uma proposta tradicional e, de forma concomitante, inovadora no que tange aos parâmetros para a definição das divisas intermunicipais. Ao mesmo tempo em que aponta novamente para os clássicos acidentes naturais e linhas artificiais como elementos de referência, torna obrigatório a representação dos mesmos em mapeamento vinculado ao Sistema de Cartográfico Nacional (SCN) e a especificação das coordenadas geográficas, de acordo com o Sistema Geodésico Brasileiro (SGB), dos pontos extremos e intermediários das feições não naturais, algo inédito até então.

\section{Projeto de Lei do Senado no 98 de 2002}

Art. $7^{\circ} \mathrm{O}$ Estudo de Sustentabilidade Sócio-ambiental deve contemplar: I - a definição dos limites dos Municípios envolvidos, mediante georreferenciamento. 
Art. 4 $\mathrm{O}$ procedimento para criar Município será requerido à Assembléia Legislativa, por $1 \%$ (um por cento), pelo menos, dos eleitores domiciliados na área que se quer emancipar.

§ 3을 requerimento deverá conter, ainda, a descrição dos limites territoriais, com preservação da continuidade geográfica e da unidade histórico-cultural e, no caso de criação ou fusão, a localização da respectiva sede e o nome proposto para o Município.

Projeto de Lei do Senado no 60 de 2008

Art. 6 Se o resultado do plebiscito for favorável, a Assembléia Legislativa votará o Projeto de Lei criando o novo município, o qual mencionará:

II - os limites territoriais do município, definidos em linhas geodésicas entre pontos bem identificados ou acompanhando acidentes naturais.

\section{Projeto de Lei da Câmara no 293 de 2008}

Art. 16 Sendo o resultado do plebiscito favorável, a Assembléia votará o projeto de lei criando o Município, que mencionará:

II - os limites territoriais do município, definidos em linhas geodésicas entre pontos bem identificados ou acompanhando acidentes naturais.

\section{Projeto de Lei do Senado no 96 de 2008}

Art. $7^{\circ}$ O Estudo de Sustentabilidade Sócio-ambiental deve contemplar:

I - a definição dos Municípios envolvidos municipais, mediante georreferenciamento.

\section{Projeto de Lei do Senado no 197 de 2011}

Art. $7^{\circ} \mathrm{O}$ procedimento para criar novo Município tem início com a apresentação à Assembléia Legislativa do requerimento respectivo, subscrito por $1 \%$ (um por cento) dos eleitores domiciliados na área que se pretende emancipar.

§ $3^{\circ}$ Em qualquer caso, o requerimento deve conter a definição dos limites territoriais, com preservação da continuidade geográfica e da unidade histórico-cultural e, no caso de criação ou fusão, a localização da respectiva sede e o nome proposto para o Município.

\section{Projeto de Lei do Senado no 104 de 2014}

Art. 7ㅇ Os EVM devem abordar os seguintes aspectos em relação ao Município a ser criado e aos demais Municípios envolvidos:

I - viabilidade econômico-financeira;

II - viabilidade político-administrativa; e

III - viabilidade socioambiental e urbana.

§ 3ㅇ A viabilidade socioambiental e urbana deverá ser demonstrada a partir do levantamento dos passivos e dos potenciais impactos ambientais e das seguintes informações e estimativas, definindo-se preliminarmente qual Município deverá assumir esses passivos:

I - novos limites municipais, que deverão ser estabelecidos a partir das seguintes condições: 
a) os limites dos Municípios devem ser descritos preferencialmente por acidentes físicos, naturais ou artificiais, perfeitamente identificáveis no terreno e representados no mapeamento de referência, o qual deverá estar vinculado ao Sistema Cartográfico Nacional (SCN); e

b) quando os limites forem descritos por linhas imaginárias, devem ser informadas as coordenadas geográficas de seus pontos extremos e de seus pontos intermediários, todas vinculadas ao Sistema Geodésico Brasileiro (SGB), recaindo tais pontos, de preferência, sobre acidentes físicos, naturais ou artificiais, perfeitamente identificáveis no terreno.

Dentro do apresentado, considerando a intenção inicial da breve pesquisa histórica de responder ao questionamento sobre a existência de parâmetros e normas para a definição das linhas limítrofes entre os municípios brasileiros, pode-se chegar a conclusão de caráter positivo. Tomando as leis estaduais apresentadas como o conjunto de orientações legais atualmente vigentes para a delimitação territorial de municípios ${ }^{8}$, levando em consideração, para isso, a situação de impasse existente devido a não promulgação da lei complementar federal citada na Emenda Constitucional no 15/96, pode-se identificar a permanência e a relevância dos elementos definidos ainda em 1938 pelo Decreto-Lei no 311 - acidentes naturais, presentes em $78 \%$ das leis, e linhas geodésicas/retas, com ocorrência em torno de $56 \%$ do referido conjunto - em adição a outros critérios, tais quais a fácil identificação (91\%), a forma harmônica (26\%), a distância (26\%), a continuidade territorial (26\%), a fixidez (22\%) e os limites já existentes (17\%) (tabela 2.1-1).

A análise do mesmo conjunto sob um viés mais qualitativo, entretanto, aponta para uma situação de orientação legal muito simplória. Se as leis ou propostas levantadas proporcionaram e proporcionam um ponto de partida importante, as mesmas pecam por uma generalização excessiva, tornando possível, na realidade, configurações territoriais das mais diversas. Aqui, a totalidade imensurável de possibilidades permite uma constatação simples: busca-se apresentar possibilidades de feições - mesmo que pouco restritivas - para a linha limítrofe em detrimento de uma discussão muito mais importante, relacionada as justificativas dos contornos territoriais adotados. Se o território é essencial para a própria existência do município, seus limites não devem ser apenas descritos, mas também justificados. Eis uma lacuna legal evidente.

\footnotetext{
${ }^{8}$ Possíveis normatizações ou orientações técnicas oriundas de órgãos federais ou estaduais para a temática dos limites intermunicipais, caso existam, ou não foram publicadas, ou a presente pesquisa falhou de forma veemente na intenção de encontrá-las.
} 
Neste contexto, ainda que não abarquem todos os critérios identificados, tornam-se necessárias algumas reflexões primordiais: quantos tipos de limites estariam, de fato, fora do conjunto abarcado por acidentes naturais ou linhas artificiais? Como identificar uma forma territorial enquanto harmônica ou não? Qual a real efetividade e racionalidade da adoção de limites já existentes? São estes os pontos desenvolvidos em seguida. 
Tabela 2.1-1 - Parâmetros para a definição de limites intermunicipais nas legislações estaduais brasileiras pós-1988.

\begin{tabular}{|c|c|c|c|c|c|c|c|c|}
\hline \multirow{2}{*}{ Estado } & \multicolumn{8}{|c|}{ Parâmetros } \\
\hline & Acidentes Naturais & Clareza/Fácil identificação & Continuidade Territorial & Distância & Fixidez & Forma Harmônica & Linhas Geodésicas/Retas & Limites já existentes \\
\hline Acre & $\mathrm{x}$ & $\mathrm{x}$ & & & $\mathrm{x}$ & $\mathrm{x}$ & $\mathrm{x}$ & \\
\hline Alagoas & $\mathrm{x}$ & $\mathrm{x}$ & & & & & $\mathrm{x}$ & \\
\hline Amapá & & $\mathrm{x}$ & $\mathrm{x}$ & & & & & \\
\hline Amazonas & $\mathrm{x}$ & $\mathrm{x}$ & & & & & $\mathrm{x}$ & \\
\hline Bahia & $\mathrm{x}$ & $\mathrm{x}$ & & & $\mathrm{x}$ & $\mathrm{x}$ & $\mathrm{x}$ & \\
\hline \multicolumn{9}{|l|}{ Ceará } \\
\hline Espírito Santo & $\mathrm{x}$ & $\mathrm{x}$ & & & & & & \\
\hline Goiás & $\mathrm{x}$ & $\mathrm{x}$ & $\mathrm{x}$ & $\mathrm{x}$ & & $\mathrm{x}$ & $\mathrm{x}$ & \\
\hline \multicolumn{9}{|l|}{ Maranhão } \\
\hline Mato Grosso & $\mathrm{x}$ & $\mathrm{x}$ & $\mathrm{x}$ & & & & $x$ & \\
\hline Mato Grosso do Sul & $\mathrm{x}$ & $\mathrm{x}$ & $\mathrm{x}$ & $\mathrm{x}$ & $\mathrm{x}$ & $\mathbf{x}$ & $\mathrm{x}$ & \\
\hline Minas Gerais & $\mathrm{x}$ & $\mathrm{x}$ & $\mathrm{x}$ & & $\mathrm{x}$ & & & \\
\hline Pará & $\mathrm{x}$ & $\mathrm{x}$ & & & & & $\mathrm{x}$ & \\
\hline Paraíba & $\mathrm{x}$ & $\mathrm{x}$ & & & & & & \\
\hline Paraná & & $\mathrm{x}$ & & & & & & \\
\hline Pernambuco & $\mathrm{x}$ & $\mathrm{x}$ & & $\mathrm{x}$ & & & $\mathrm{x}$ & $\mathrm{x}$ \\
\hline \multicolumn{9}{|l|}{ Piauí } \\
\hline Rio de Janeiro & $\mathrm{x}$ & $\mathrm{x}$ & & & $\mathrm{x}$ & & & \\
\hline \multicolumn{9}{|l|}{ Rio Grande do Norte } \\
\hline Rio Grande do Sul & $\mathrm{x}$ & $\mathrm{x}$ & & & & $\mathrm{x}$ & $\mathrm{x}$ & $\mathrm{x}$ \\
\hline Rondônia & & $\mathrm{x}$ & $\mathrm{x}$ & & & & & \\
\hline Roraima & $\mathrm{x}$ & $x$ & & & & $\mathrm{x}$ & $\mathrm{x}$ & $\mathrm{x}$ \\
\hline Santa Catarina & $\mathrm{x}$ & $\mathrm{x}$ & & $\mathrm{x}$ & & & $\mathrm{x}$ & $\mathrm{x}$ \\
\hline São Paulo & $\mathrm{x}$ & $\mathrm{x}$ & & $\mathrm{x}$ & & & $\mathrm{x}$ & \\
\hline Sergipe & $\mathrm{x}$ & $\mathrm{x}$ & & & & & & \\
\hline Tocantins & & & & $\mathrm{x}$ & & & & \\
\hline Total & 18 & 21 & 6 & 6 & 5 & 6 & 13 & 4 \\
\hline
\end{tabular}

Fonte: Elaborado pelo autor 


\subsection{ACIDENTES NATURAIS E LINHAS GEODÉSICAS}

A consulta à bibliografia clássica sobre a temática das fronteiras torna possível a identificação da questão da tipologia enquanto um de seus aspectos de maior ocorrência e discussão. A análise ou a proposição de uma classificação dos limites territoriais estaria presente em meio às contribuições de praticamente todos os famigerados autores da área.

A separação das fronteiras em externas (ou internacionais) ou internas, citada na primeira parte deste trabalho, por exemplo, destaca-se dentro de uma ótica centrada no Estado-Nação, considerando elementos primordialmente relacionados à soberania e a divisão político-administrativa de cada país. Mas esta não é a única. Enfoques distintos, construídos a partir do predomínio de um determinado aspecto fronteiriço sobre outro, produziriam classificações das mais diversas. Hartshorne (1936), tomando como referência a história e o povoamento, dividiria os limites políticos em dois grandes grupos: os antecedentes ou os subsequentes à ocupação humana ou a própria formação estatal. Haushofer, por sua vez, dentro de um prisma extremamente militarista, apresentaria, em 1939, uma divisão em fronteiras de ataque, de defesa, de manobra, de equilíbrio, decadentes ou apáticas. (JONES, 1945)

Neste contexto, embora seja difícil a precisa quantificação das tipologias existentes (ou até mesmo o reconhecimento de suas semelhanças e diferenças), pode-se identificar, sem sombra de dúvidas, a oposição entre limites naturais e limites artificiais como a classificação de maior relevância existente até hoje. Dentro disto, assim como aponta Jones (1945), dois tipos de entendimento poderiam estar atrelados ao natural/artificial das fronteiras: um, baseado na essência da linha fronteiriça, ou seja, na distinção entre elementos naturalmente ou artificialmente constituídos enquanto limite territorial, e outro, focado primordialmente na feição, a qual poderia estar associada a elementos provenientes da natureza ou a elementos criados pelo homem (materializados ou não). 
"Natural boundary" has many meanings. Two of its diverse connotations can be expressed by "naturally-marked boundary" and "naturally-made barrier." A naturally-marked boundary - for example, a small stream - may not be a barrier of any consequence. Some naturally-made barriers - for example, many deserts - present no naturally-marked boundary sites. (JONES, 1945)

A proposta tipológica de Ratzel, inserida dentro de suas concepções particulares sobre o território, constitui-se como um exemplo do primeiro entendimento citado por Jones. Para o geógrafo alemão, as fronteiras poderiam ser divididas em três grandes grupos: políticas, naturais e artificiais. Enquanto as políticas estariam atreladas a distintas situações de "contato" entre dois ou mais Estados, as naturais abarcariam todos os elementos provenientes da natureza (montanhas, rios, lagos, desertos, florestas, etc.) que atuassem como barreira ou limitador do povoamento e da ocupação humana. As artificiais, por sua vez, consistiriam em qualquer fronteira criada pelo homem, mesmo que apoiadas sobre um marco físico (CATAIA, 2010).

Esta dualidade entre naturais e artificiais seria, entretanto, questionada e criticada por Vallaux (1914), sendo qualificada enquanto uma distinção sem um alcance ou valor científico verdadeiro. Para o mesmo, a ideia de limite natural, intimamente atrelada à noção de proteção e obstáculo, não apresentaria qualquer tipo de relevância na atualidade, haja visto que os principais acidentes geográficos (rios, cadeias de montanhas, desertos, etc) já haviam sido "vencidos" pelo homem. Além disso, sob um ponto de vista centrado na figura do Estado, as fronteiras tidas como artificiais seriam aquelas verdadeiramente naturais, estando de acordo com a natureza da sociedade política.

Boggs (1940), por sua vez, partindo de constatação semelhante da problemática da simples qualificação das fronteiras entre naturais e artificiais, propõe a divisão das mesmas em quatro classes principais: físicas, geométricas, antropogeográficas e complexas ou compostas. Esta classificação, ao também apresentar as possibilidades existentes para cada grupo, consistir-se-ia em uma das mais (senão a mais) completa proposta tipológica relacionada à temática. São elas:

Tipos físicos:

- Montanhas

- Linhas de cumeada; 
- Divisor de águas.

- Desertos

- Lagos, baías e estreitos

- Linhas médias;

- Principal canal navegável;

- Margens.

- Rios e canais

- Linhas médias;

- Talvegue;

- Margens.

- Pântanos.

- Fronteiras em águas territoriais.

- Cotas.

Tipos geométricos:

- Linha reta (meridianos e outros círculos máximos).

- Paralelo de latitude.

- Linhas de rumo ou loxodrómica.

- Arco de círculo.

- Linha paralela ou equidistante a linha de costa ou rio.

Tipos antropogeográficos:

- Fronteiras tribais.

- Fronteiras linguísticas.

- Fronteiras religiosas.

- Fronteiras econômicas.

- Fronteiras históricas.

- Fronteiras culturais. 
- Limites de propriedades privadas.

Tipos complexos ou compostos

A proposta de Boggs apresenta, desta forma, dois tipos de abordagem. A divisão entre físicas e geométricas ocorre mediante a consideração da feição utilizada como referência para o estabelecimento do limite, ou seja, acaba por se caracterizar como uma nova roupagem para a divisão entre naturais e artificiais dentro do segundo enfoque levantado por Jones. O grupo antropogeográfico, por sua vez, dotado de maior complexidade, estaria relacionado com a gênese da fronteira, o que não excluiria a necessidade de adoção de alguma feição física ou geométrica para a sua definição ${ }^{9}$.

Dentro do exposto, tomando como referência a classificação de Boggs e, retornando a discussão sobre os critérios e parâmetros legais para a delimitação de municípios no Brasil, quantos tipos de limites estariam, de fato, fora do conjunto abarcado por acidentes naturais ou linhas artificiais/geodésicas? Tomando como referência o correlacionamento, simples e perfeitamente possível, entre os acidentes naturais e os tipos físicos e entre linhas artificiais/geodésicas e os tipos geométricos, a resposta mais prudente seria praticamente nenhum, haja vista que a totalidade dos subtipos elencados pelo referido autor estaria contemplada dentro desta exigência.

Desta forma, assim como já apontado, as possibilidades para o desenho territorial municipal tornam-se incontáveis, abrindo espaço, por sua vez, para a "adequação" dos limites de acordo com interesses particulares, pouco transparentes ou até mesmo obscuros. Deve-se compreender que o aparecimento dos acidentes naturais e das linhas geodésicas na legislação brasileira ocorreu em meio a propósitos específicos para à época, na tentativa de solucionar ou diminuir a deficiência existente até então na delimitação municipal. A simples repetição desta exigência nos dias atuais, desconsiderando todo o avanço técnico, científico e até mesmo jurídico ocorrido ao longo destas oito décadas, torna, sem dúvida, a sua real efetividade como algo totalmente questionável.

\footnotetext{
${ }^{9}$ Os tipos complexos ou compostos são poucos desenvolvidos pelo próprio autor, sendo definidos apenas como "such as compromise lines adapted to multiplicity of factors" (BOGGS, 1940).
} 


\subsection{A FORMA DO TERRITÓRIO}

Segundo Maceachren (1985), a forma é uma característica espacial fundamental para a pesquisa e estudo da Geografia. Inicialmente utilizada como elemento apenas descritivo, a forma geométrica passaria a se apresentar como uma ferramenta de análise, tanto para campos da Geografia Física como para campos da Geografia Humana, podendo-se citar, como exemplos respectivos, os estudos referentes às formas de bacias hidrográficas e às formas de aglomerações urbanas.

Sob uma ótica geopolítica, Backheuser (1952) e Meira Mattos (1979) apresentam a forma do território enquanto um fator de extrema relevância estratégica, uma vez que influenciaria (ou poderia influenciar) diretamente na política e no domínio dos espaços delimitados de poder, facilitando ou dificultando a coesão dos Estados. Em meio à dificuldade de identificação e correlação direta das formas territoriais, dotadas de contornos não muito simples, com uma figura geométrica específica, ambos os autores resgatam a classificação proposta por Renner:

Formas compactas: em princípio, as mais favoráveis à coesão do Estado. Aproximando-se da figura geométrica do círculo, apresentam a vantagem de abranger uma maior área dentro de um mesmo perímetro (quanto menores as fronteiras, menores as possibilidades de atrito). Além disso, a equidistância entre o centro e os pontos extremos favorece o equilíbrio e a uniformidade de desenvolvimento.

Formas alongadas: comparadas com as forma compactas, as formas alongadas apresentam a necessidade de um maior perímetro para o "recobrimento" de uma mesma área, potencializando a possibilidade de problemas fronteiriços. A maior distância entre os pontos extremos no sentido do alongamento tendem a contribuir para uma maior diferenciação entre os mesmos.

Formas recortadas: formas dotadas de extensas linhas fronteiriças (situação potencialmente problemática em períodos de conflito), com "predomínio" do perímetro sobre a área.

Formas fragmentadas: caracterizadas por estados arquipélagos ou por áreas descontínuas, apresentam a maior desvantagem para a coesão, dificultando o exercício da soberania. 


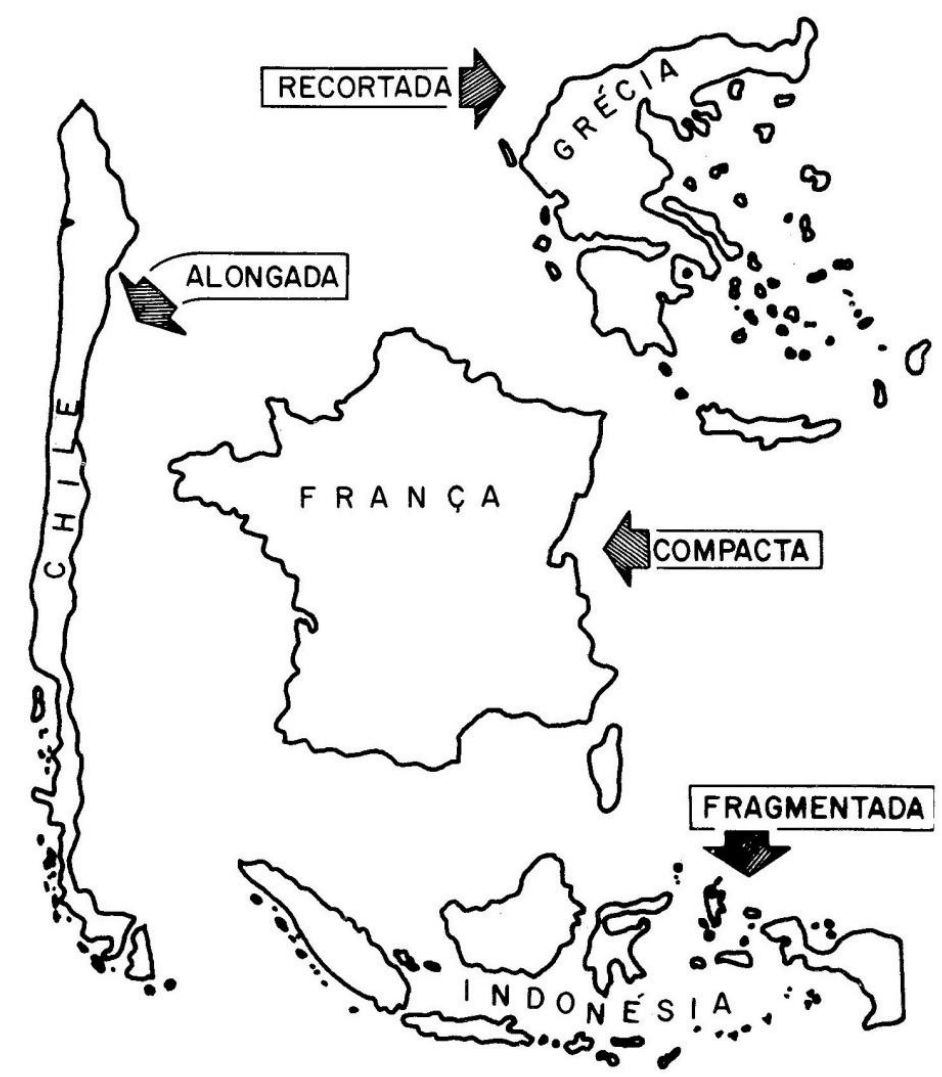

Figura 2.3-1 - Tipos de forma territorial. Fonte: Meira Mattos (1979)

Haggett (1976), por sua vez, afirma que a repartição da superfície pode ter sua eficácia mensurada a partir de dois modos: o primeiro, referente a eficácia do movimento, consistiria na distância entre centro e periferia no interior do território; o segundo, ligado a chamada eficácia dos limites, estaria atrelado ao perímetro territorial, em relação direta com possíveis gastos na defesa ou no cercamento de uma determinada área. Nota-se, neste contexto, que a forma geométrica surge como um elemento de considerável relevância para a análise do território.

Ainda segundo o autor, dentro do referido processo, a busca por cenários mais econômicos deve, obrigatoriamente, considerar a adoção de polígonos regulares em detrimento dos irregulares. Partindo da comparação entre um quadrado e um retângulo de mesma área, Haggett demonstra como a primeira figura apresenta melhores condições de acessibilidade em um possível deslocamento entre um ponto qualquer de sua borda para o seu centro. A "deformação" do quadrado para uma forma retangular, além de ocasionar um aumento na extensão do perímetro, acabaria por acarretar em um maior distanciamento entre os seus extremos. 
Dentro desta lógica, a figura geométrica do círculo seria o polígono regular mais econômico, a forma ideal por assim dizer, uma vez que consistiria em uma situação de equidistância entre qualquer ponto extremo e o centro em concomitância com a redução da linha perimétrica.

Los polígonos regulares son unas formas más econômicas que lós polígonos irregulares. Si considerarmos, por ejemplo, el polígono de cuatro lados, vemos que, si se trata de um kilómetro cuadrado, el movimiento más largo (es decir desde el centro has el punto más alejado del cuadrado) es de $0,707 \mathrm{~km}$; el perímetro es de $4 \mathrm{~km}$, Si transformamos este cuadrado em um rectángulo de igual superficie pero com dos lados más largos que lós outros dos, el movimiento más largo puede alcanzar $1,031 \mathrm{~km}$ y el perímetro $5 \mathrm{~km}$. La experiencia demuestra que cuanto mayor es el contraste entre los lados mayor e menor de um rectángulo, menos econômico es este, tanto em términos de acessibilidad a partir del centro, como desde el punto de vista de la longitud del perímetro. (HAGGETT, 1976)

Los círculos son los polígonos regulares más económico. Si se imagina uma serie continua de polígonos regulares comezando por el triángulo y siguiendo por el cuadrado, el pentágono, el hexágono, etc., vemos que em cada estádio aumenta em uno el número de lados y de vértices. El caso límite es obviamente el círculo, que puede ser considerado como um polígono regular com um número infinito de lados y vértices. Si examinamos esta secuencia vemos que, si el área permanece constante, la accesibilidad a partir del centro, medida como distancia radial máxima, va mejorando, y el perímetro va disminuyendo. (HAGGETT, 1976)
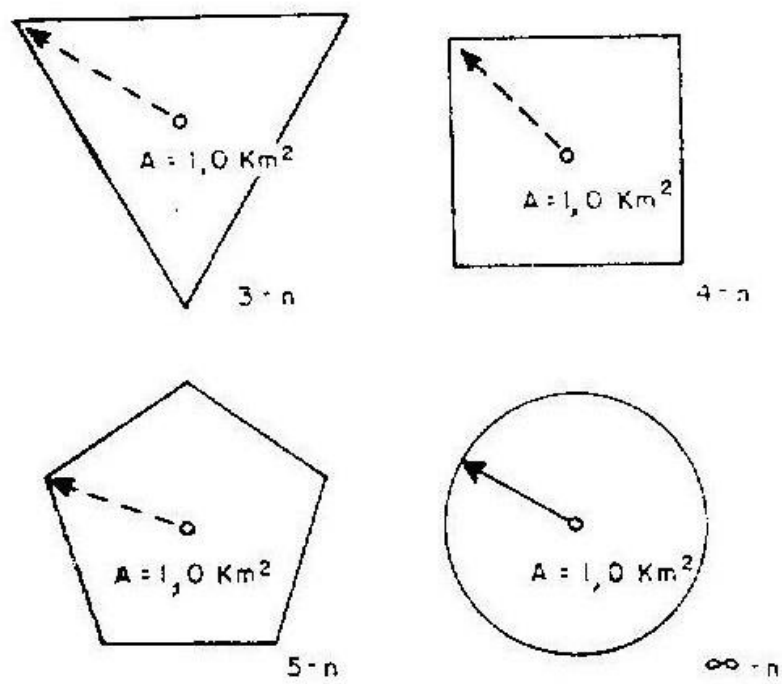

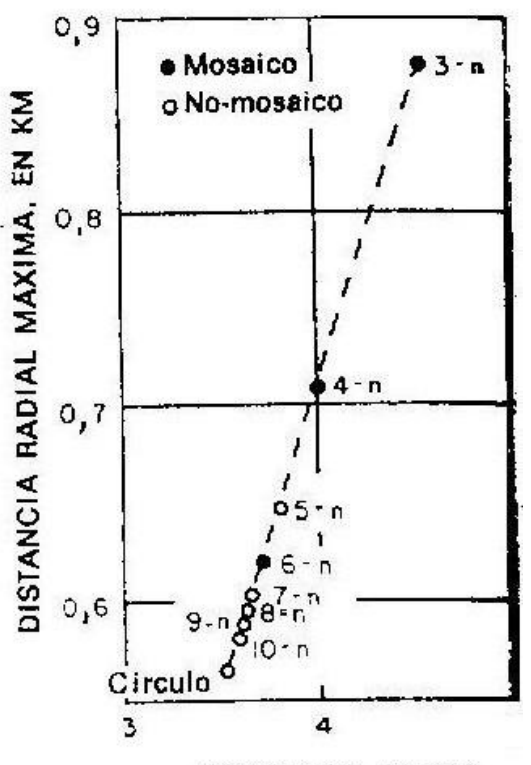

PERIMETRO, EN KM

Figura 2.3-2 - Polígonos regulares - distância para o centro e perímetro.

Fonte: Adaptado de Haggett (1979) 
Em uma abordagem mais prática, o "fator forma" também pode ser encontrado em meio a discussões sobre o processo de redistritamento nos Estados Unidos. Parte relevante dos trabalhos destinados a analisar ou a propor alterações na organização espacial norte-americana para propósitos eleitorais considera a adoção de parâmetros de compacidade como um elemento de grande relevância para a delimitação dos territórios distritais. Embora outros fatores tenham de ser considerados - equilíbrio populacional e representação de interesses de minorias/grupos étnicos, por exemplo - a forma compacta, ao ser associada diretamente a coesão do território, acaba aparecendo como elemento imprescindível para o estabelecimento coerente dos limites dos distritos estadunidenses, tanto no âmbito das reflexões acadêmicas como na normatização legal em inúmeros estados do país. Como bem aponta Morrill (1987):

Compactness is inherently preferable to irregularity, simply because, ceteris paribus, compact territories tend to haver easier communication and greater internal cohesion, because most human settlement is clustered, and because there is a direct relation between the cost of creating a sense of common participation and irregularity of territory. (MORRILL, 1987)

Em suma, embora possam existir diversas formas e contextualizações distintas para o estudo da influência da forma sobre o espaço e o território, a convergência de ambas para a idealização da forma compacta ou circular é notória, seja na associação a aspectos de defesa militar, seja em fatores de melhor acessibilidade e homogeneidade territorial. O problema, entretanto, reside na subjetividade atrelada à identificação das mesmas. A simples classificação de uma forma territorial enquanto compacta, alongada ou recortada, por exemplo, pode variar de acordo com a interpretação individual de cada um.

Tomemos como exemplo um caso apresentado por Meira Mattos (1979) e Backheuser (1952): a Grécia. O território grego é apontado pelo primeiro autor como um exemplo de forma recortada. Mas, atentando-se para a simples figura apresentada (figura 2.3-1), não poderia a Grécia estar enquadrada no campo das formas fragmentadas? A existência de centenas ou milhares de ilhas gregas não seria suficiente para isso? Para Backheuser (1948) possivelmente sim, uma vez que o mesmo apresenta a Grécia como exemplo de país fragmentado. Pode-se, dentro 
disto, perceber que a adoção de uma sistematização comum pelos autores - no caso a de Renner - não impediu a ocorrência de interpretações divergentes.

Neste contexto, assim como aponta Maceachren (1985), a utilização de métodos e processos matemáticos para a medição e classificação das formas surge como uma alternativa à mera interpretação visual. Mas é aqui que reside outro problema. Se as possibilidades de interpretações eram inúmeras, a quantidade de métodos para o cálculo de índices de forma também não são pequenas. Em meio a isto, a adoção da relação entre perímetro e área ou da relação entre as áreas de círculos inscritos, circunscritos ou de mesma área, por exemplo, podem ocasionar análises divergentes sobre um mesmo território. Eis uma dificuldade real para a adoção da forma como parâmetro para a delimitação territorial.

De qualquer maneira, mesmo não estando presente nas atuais propostas de regulamentação da Emenda Constitucional no 15 de 1996, a preocupação com a forma pode ser encontrada em algumas legislações estaduais anteriores a mesma. Conforme o levantamento apresentado anteriormente, é possível identificar considerações acerca da forma para o estabelecimento dos limites intermunicipais nos estados do Acre, Bahia, Goiás, Mato Grosso do Sul, Rio Grande do Sul e Roraima. A orientação é praticamente a mesma em todos os casos: busca por formas harmônicas não assimétricas em detrimento de alongamentos e estrangulamentos exagerados. Dentro desta amostra, embora a compactação do território, mesmo que não explicitada, apareça como preocupação legal real, a generalização excessiva pouco contribui para uma efetivação prática do intentando. Como mensurar um alongamento ou estrangulamento exagerado? Como identificar com precisão uma forma harmônica? Cai-se, assim, novamente no problema da subjetividade.

Passemos então a análise empírica das formas geométricas dos municípios brasileiros como forma de verificação do peso deste parâmetro para a delimitação dos respectivos territórios. Seria possível identificar um padrão ou uma intenção, mesmo que não atrelada a aspectos legais, de formação de municípios circulares/ compactos? Nos estados em que a forma esteve presente na lei, os municípios criados sob a vigência da mesma respeitaram esse critério? São as duas questõeschave a serem respondidas.

Como apontando acima, a quantidade de métodos para o cálculo de índices de circularidade e compacidade é grande, não havendo, na literatura consultada, um predomínio indiscutível de um deles sobre os demais. Se os resultados obtidos com 
aplicação de alguns destes métodos podem parecer mais coerentes, os mesmos, entretanto, estão comumente associados a uma complexidade de cálculos e fórmulas, o que, por sua vez, acaba tornando o processo um tanto quanto moroso (MACEACHREN, 1985). Dentro disto, optou-se pela adoção de uma ferramenta prioritariamente mais prática, a partir da utilização de uma plataforma $\mathrm{SIG}^{10}$, para o cálculo do referido índice. Nesta, a relação entre o comprimento - correspondente ao maior eixo do polígono territorial - e a largura - correspondente à medida, perpendicular ao maior eixo, existente entre os pontos extremos do território - ao produzir um valor numérico entre zero e um, possibilita a qualificação da figura analisada mediante a sua colocação neste intervalo. Quando mais próximo de um, mais circular/compacto é o território (figura 2.3-3).

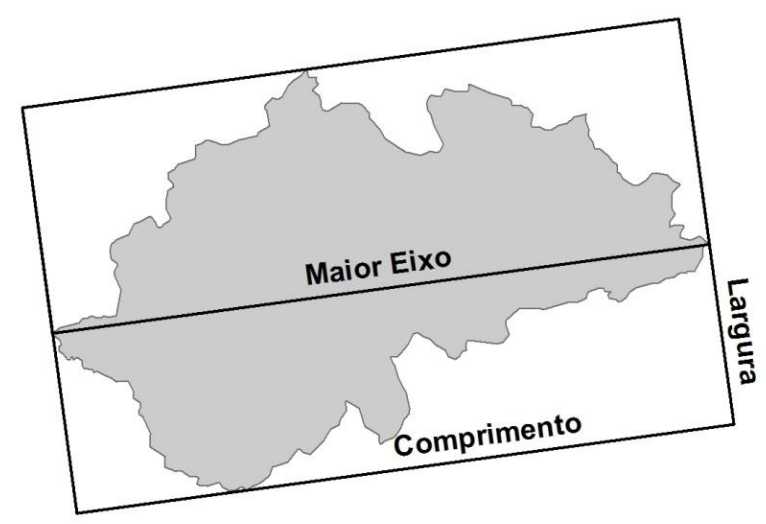

Figura 2.3-3 - Parâmetros para o cálculo do Índice de Circularidade adotado.

Fonte: Elaborado pelo autor

Os dados gerados, agrupados por estado da federação, ao serem representados estatisticamente em gráficos e cartograficamente através de mapas temáticos (figuras 2.3-4 a 2.3-10), tornam possível uma constatação simples: o conjunto dos municípios do país não apresenta um padrão nítido no que tange a forma geométrica do território. Considerando a repartição das amostras estaduais em 10 classes de circularidade (de 0 - 0,1 até 0,9-1), nota-se uma distribuição "aleatória", não havendo, de uma forma geral, um claro predomínio de uma classe sobre as demais. Além disso, os índices obtidos apontam para uma maior ocorrência de formas pouco circulares/compactas, só havendo, por exemplo, um estado com valor acima de 0,5 (Rio Grande do Norte) ${ }^{11}$ (figura 2.3-11).

\footnotetext{
${ }^{10}$ Utilizou-se a ferramenta Polygon characteristics da extensão ET GeoWizards do ArcGIS 9.3.

${ }^{11}$ Considerando-se a mediana das amostras para cada estado.
} 

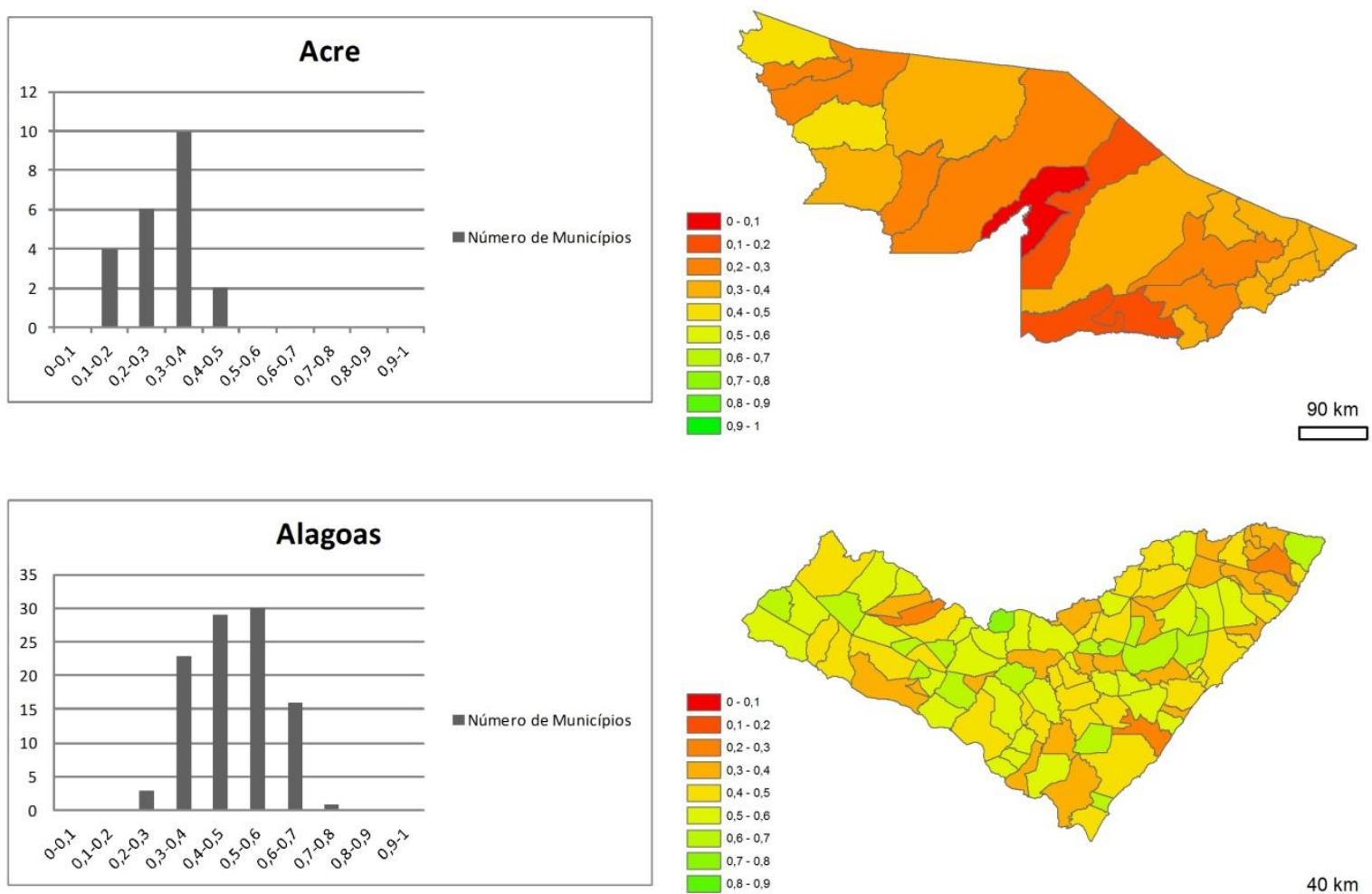

$40 \mathrm{~km}$
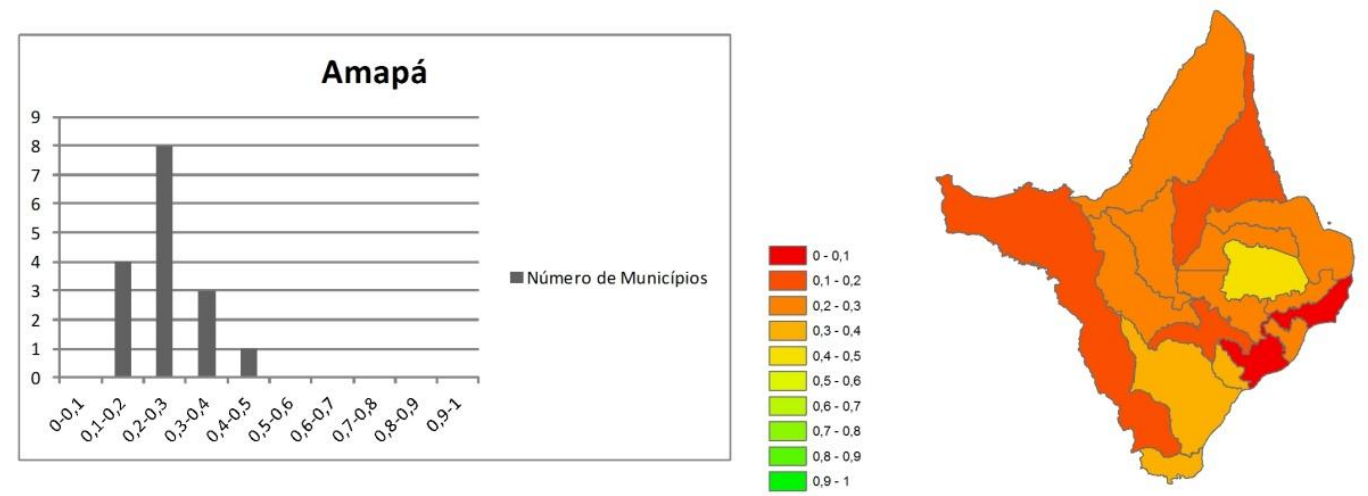

$100 \mathrm{~km}$
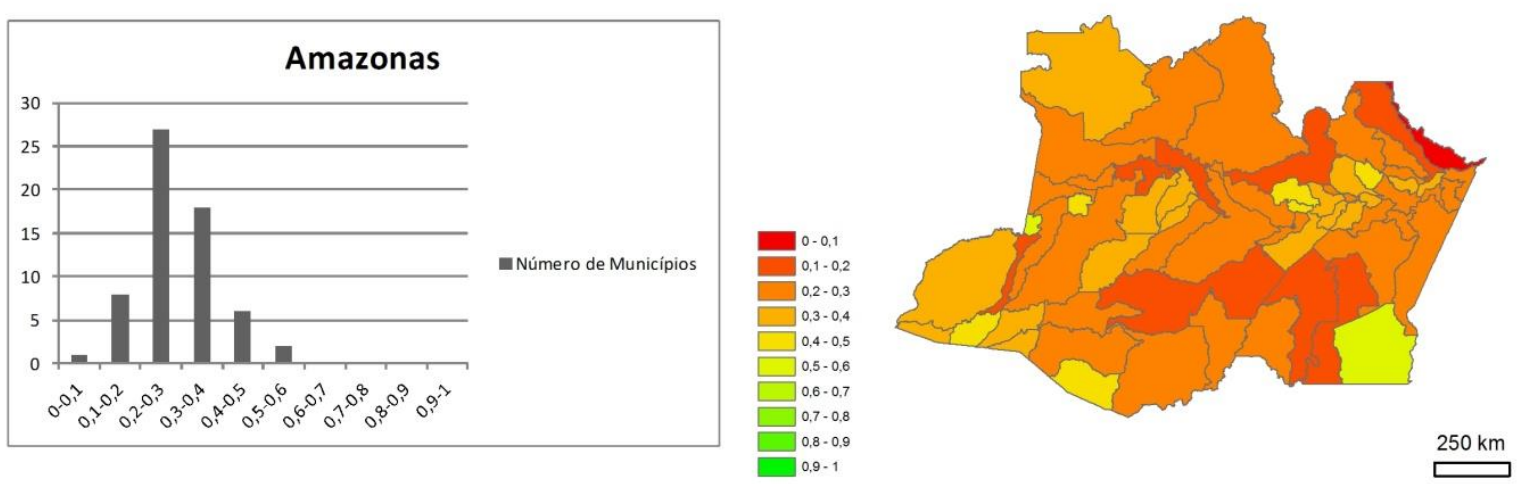

Figura 2.3-4 - Índice de Circularidade dos municípios brasileiros - Acre, Alagoas, Amapá e Amazonas. Fonte: Elaborado pelo autor 

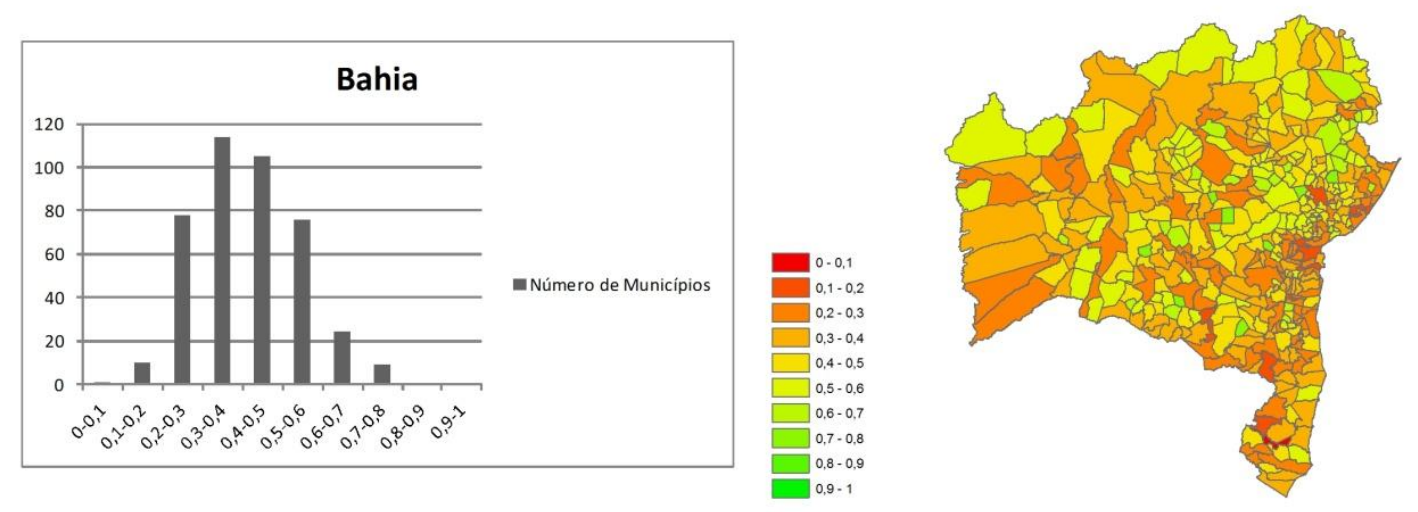

$170 \mathrm{~km}$
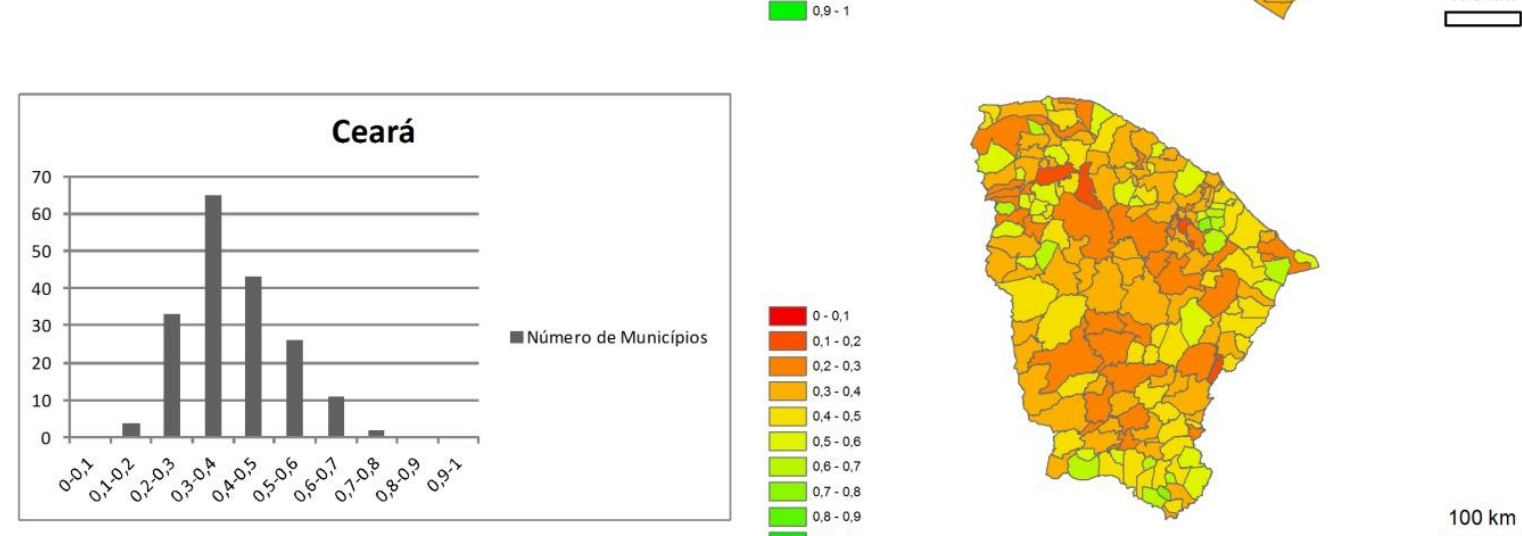

$0,8-0,9$
$0,9-1$

$100 \mathrm{~km}$
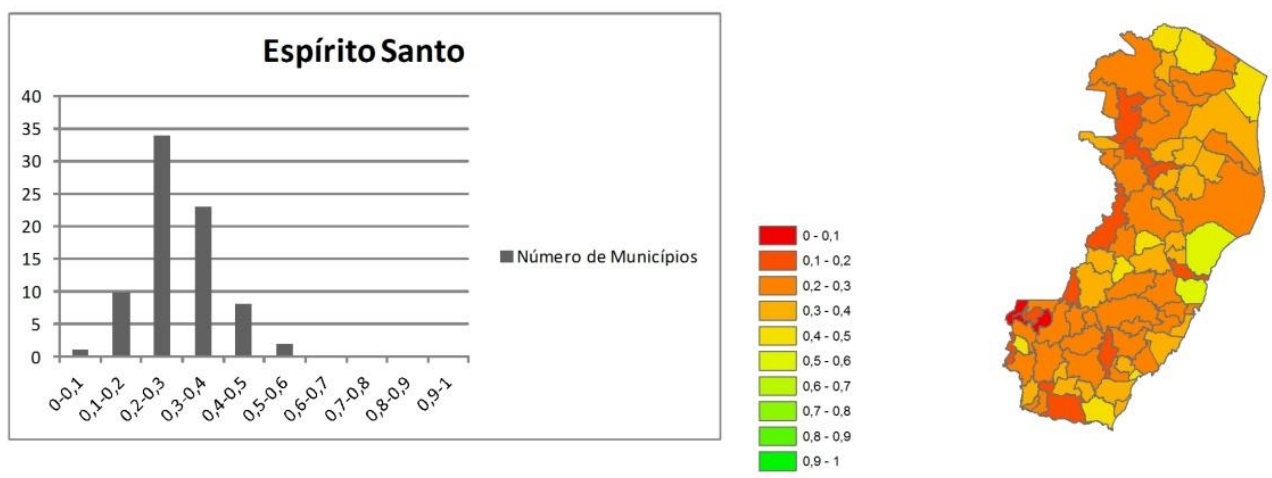

$70 \mathrm{~km}$
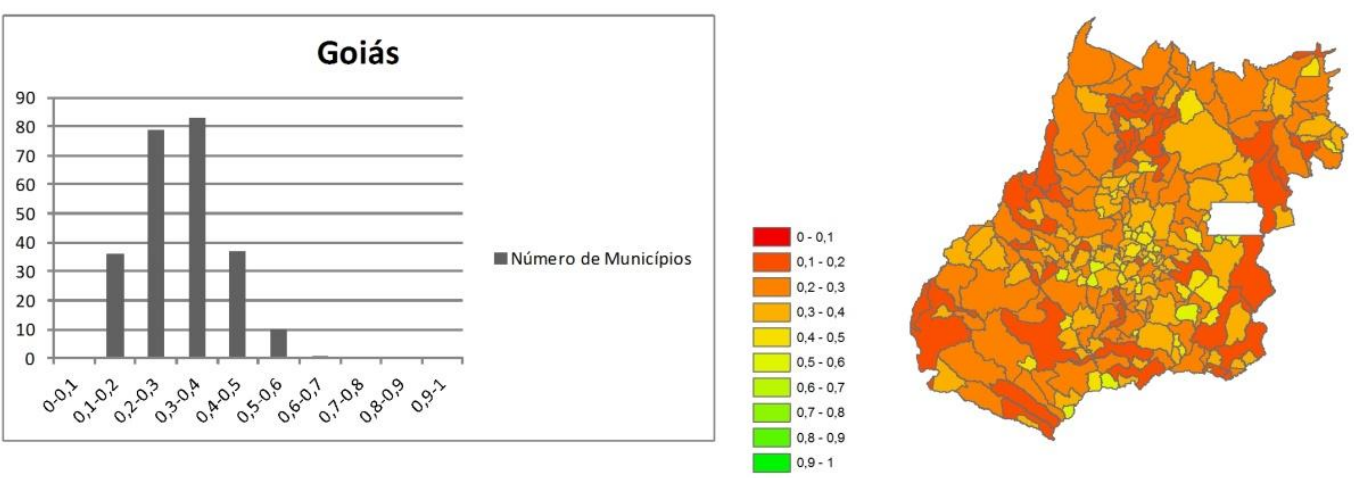

$140 \mathrm{~km}$

Figura 2.3-5 - Índice de Circularidade dos municípios brasileiros - Bahia, Ceará, Espírito Santo e Goiás. Fonte: Elaborado pelo autor 

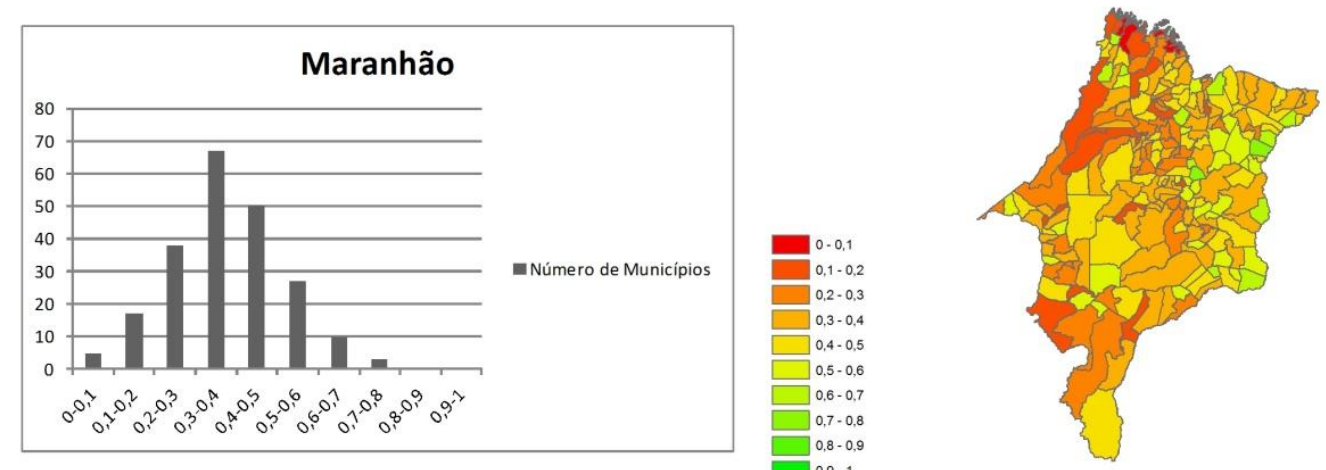

$170 \mathrm{~km}$
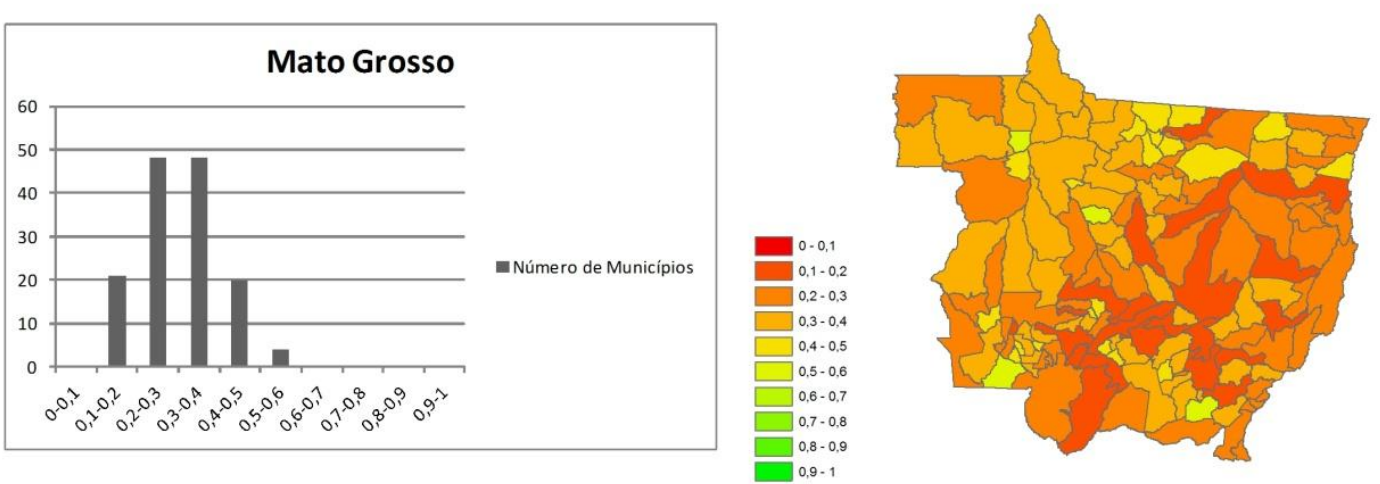

$200 \mathrm{~km}$
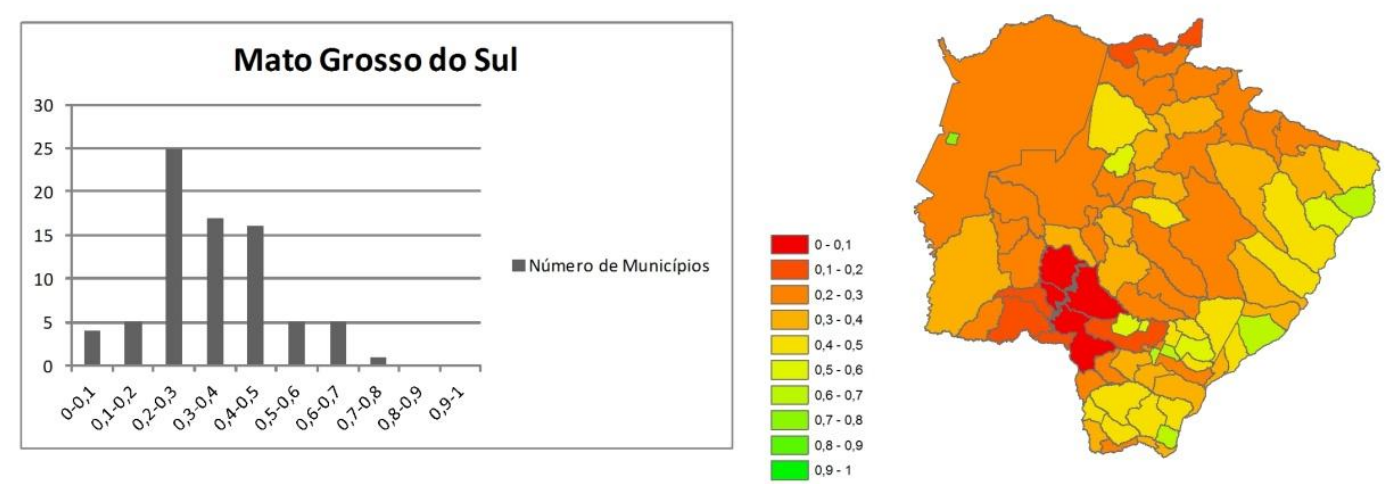

$130 \mathrm{~km}$
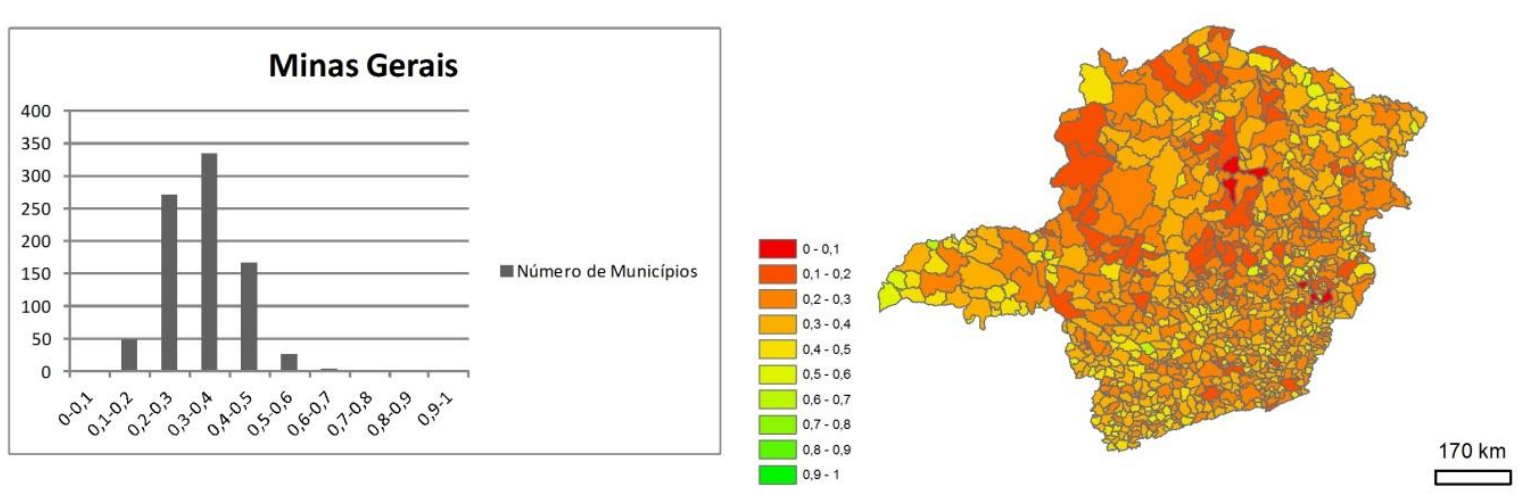

Figura 2.3-6 - Índice de Circularidade dos municípios brasileiros - Maranhão, Mato Grosso, Mato Grosso do Sul e Minas Gerais. Fonte: Elaborado pelo autor 

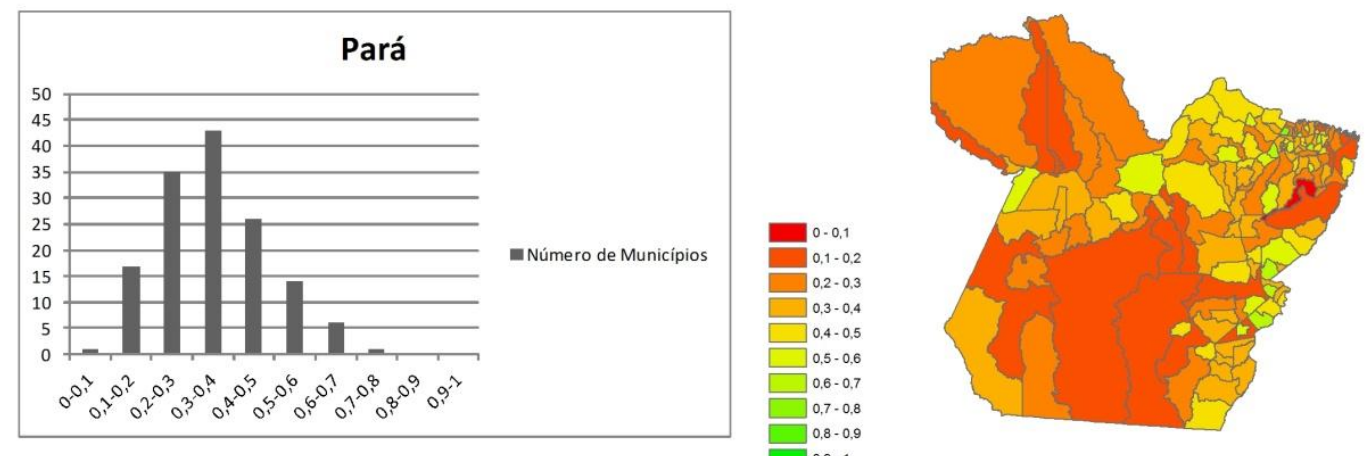

$250 \mathrm{~km}$
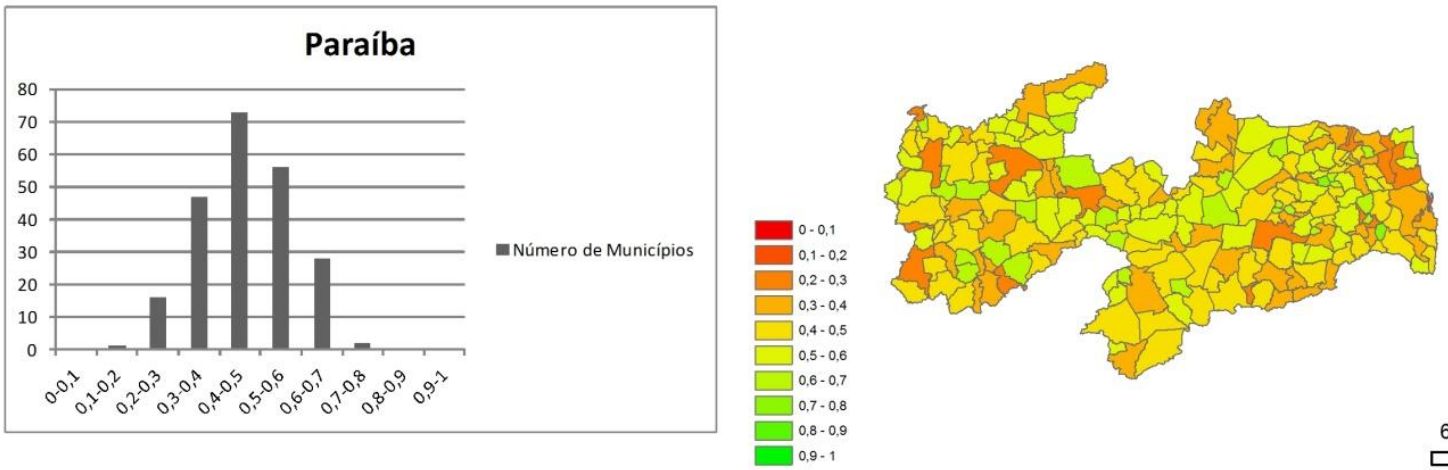

$60 \mathrm{~km}$
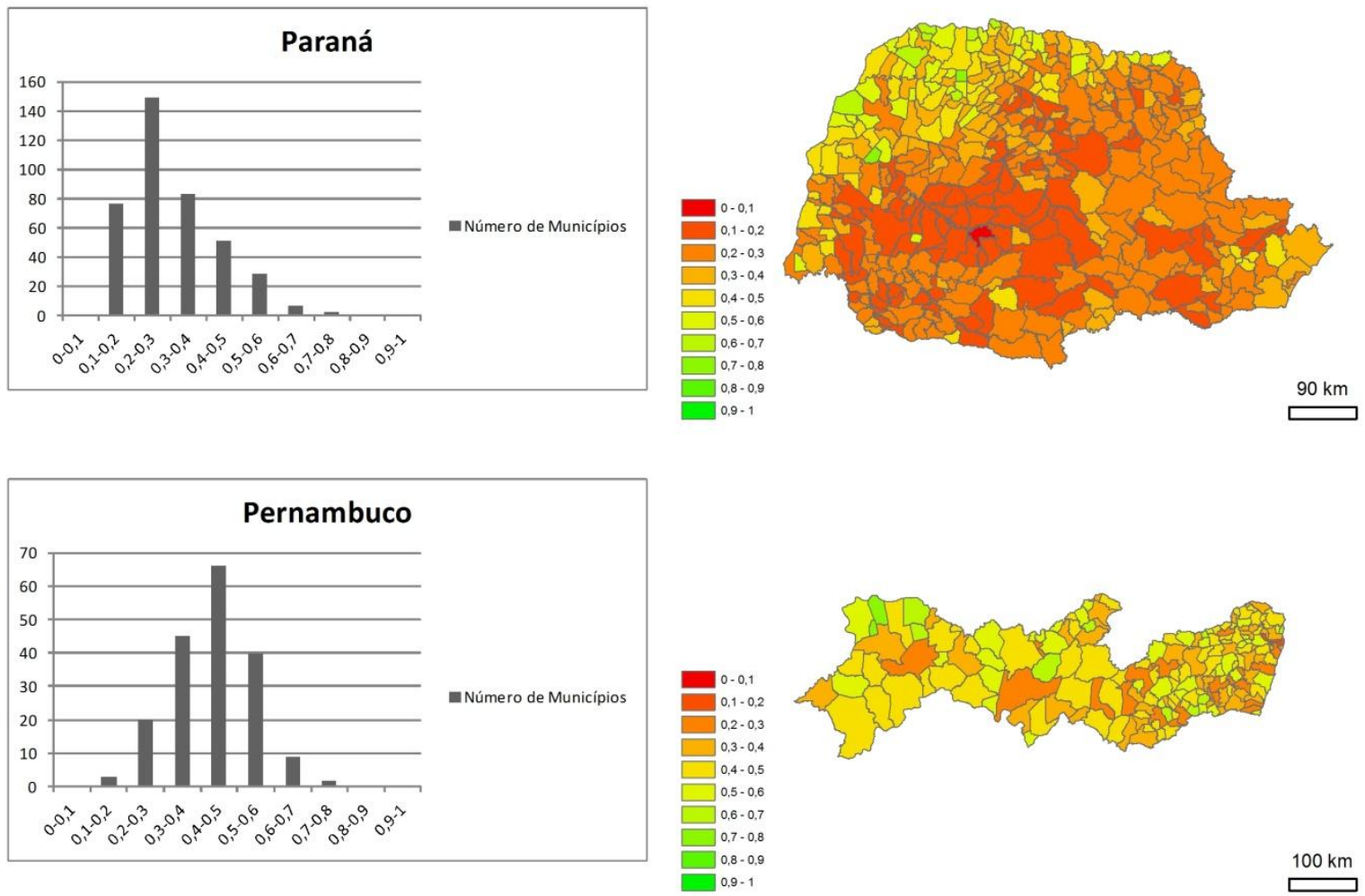

Figura 2.3-7 - Índice de Circularidade dos municípios brasileiros - Pará, Paraíba, Paraná e Pernambuco. Fonte: Elaborado pelo autor 

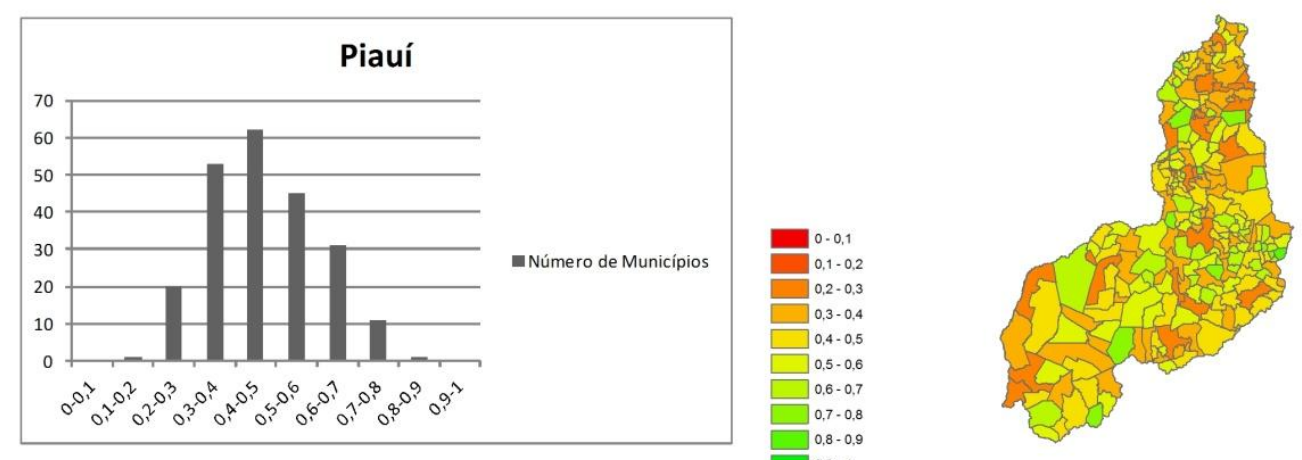

$160 \mathrm{~km}$
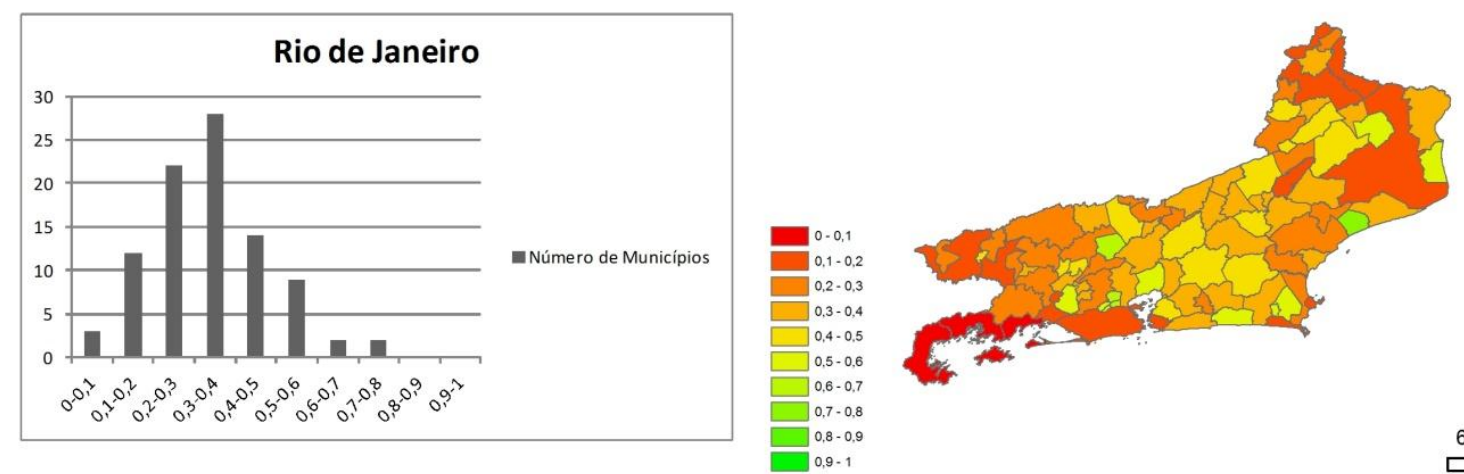

$60 \mathrm{~km}$
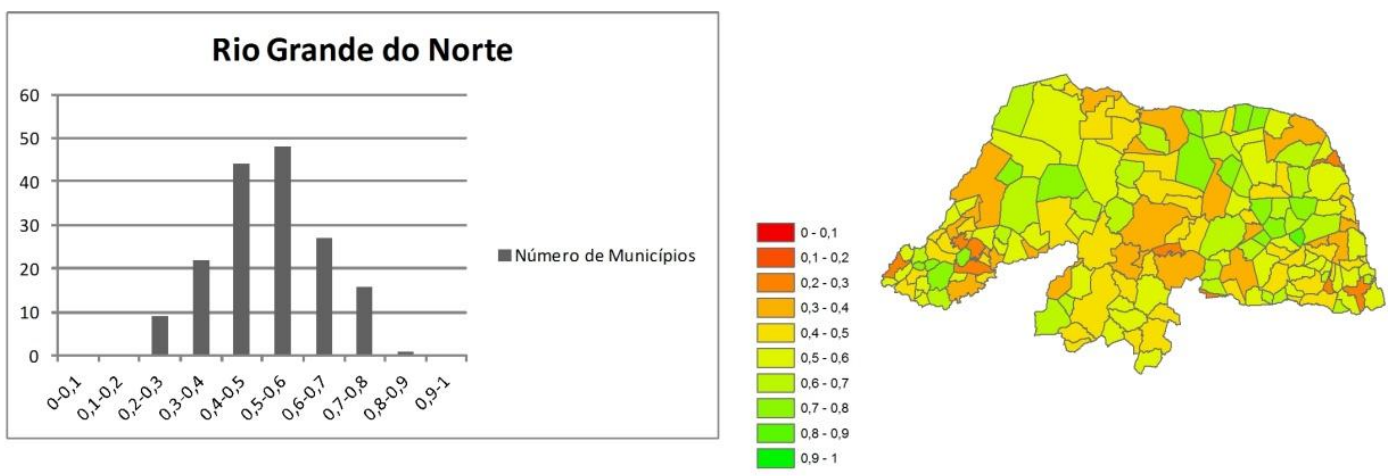

$60 \mathrm{~km}$
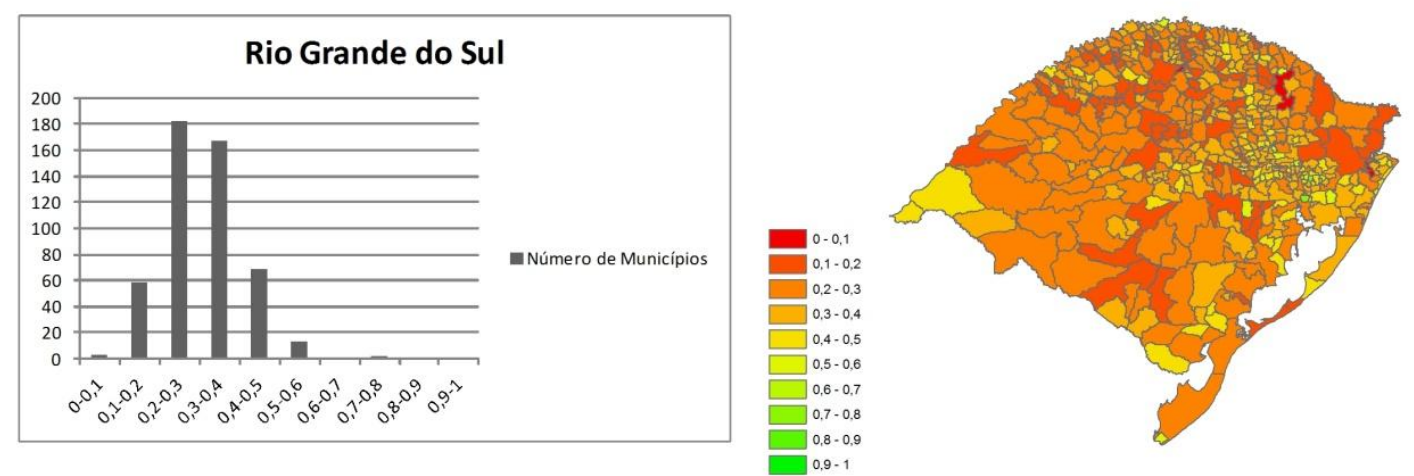

$130 \mathrm{~km}$

Figura 2.3-8 - Índice de Circularidade dos municípios brasileiros - Piauí, Rio de Janeiro, Rio Grande do Norte e Rio Grande do Sul. Fonte: Elaborado pelo autor 

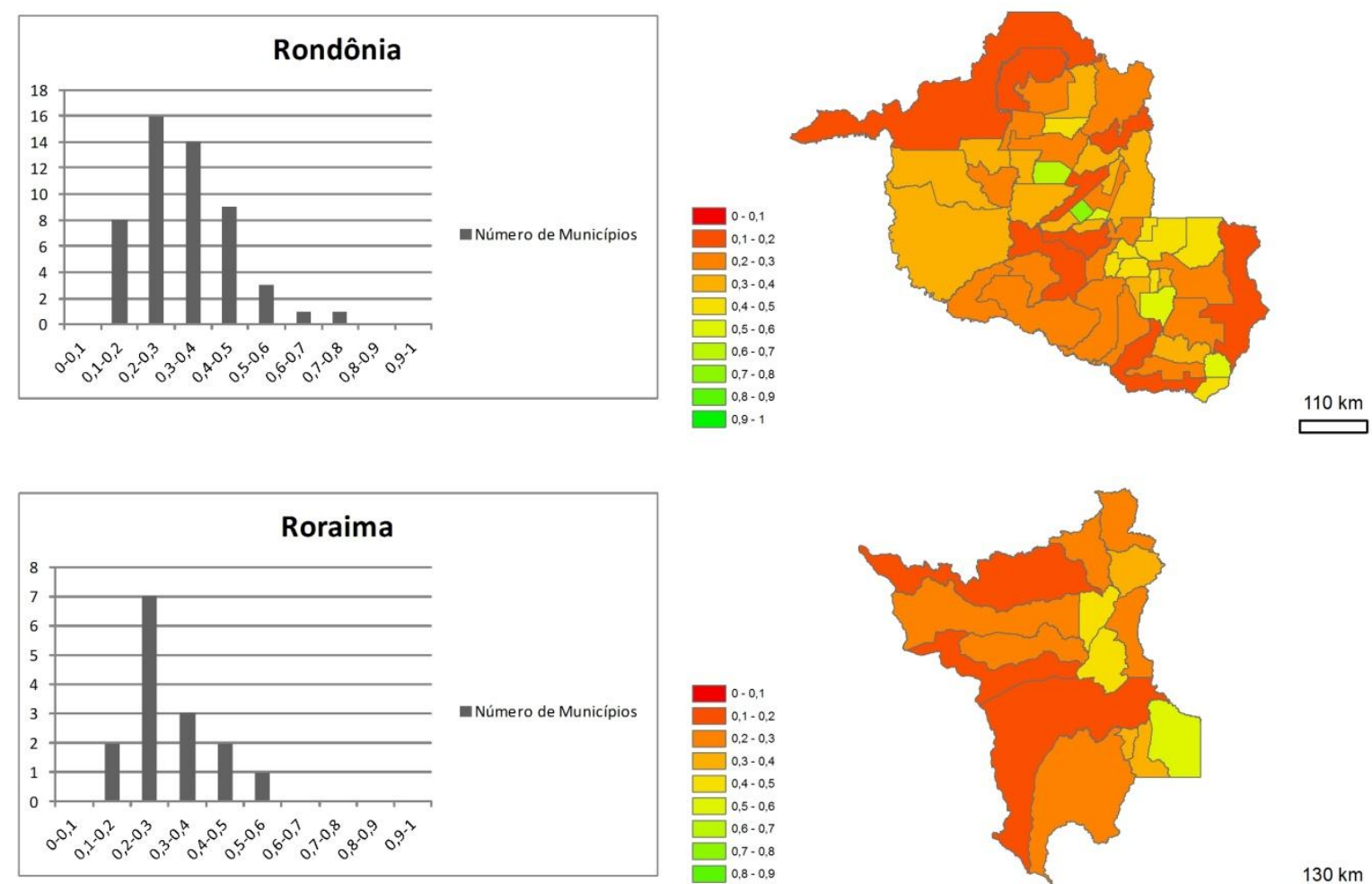

$130 \mathrm{~km}$
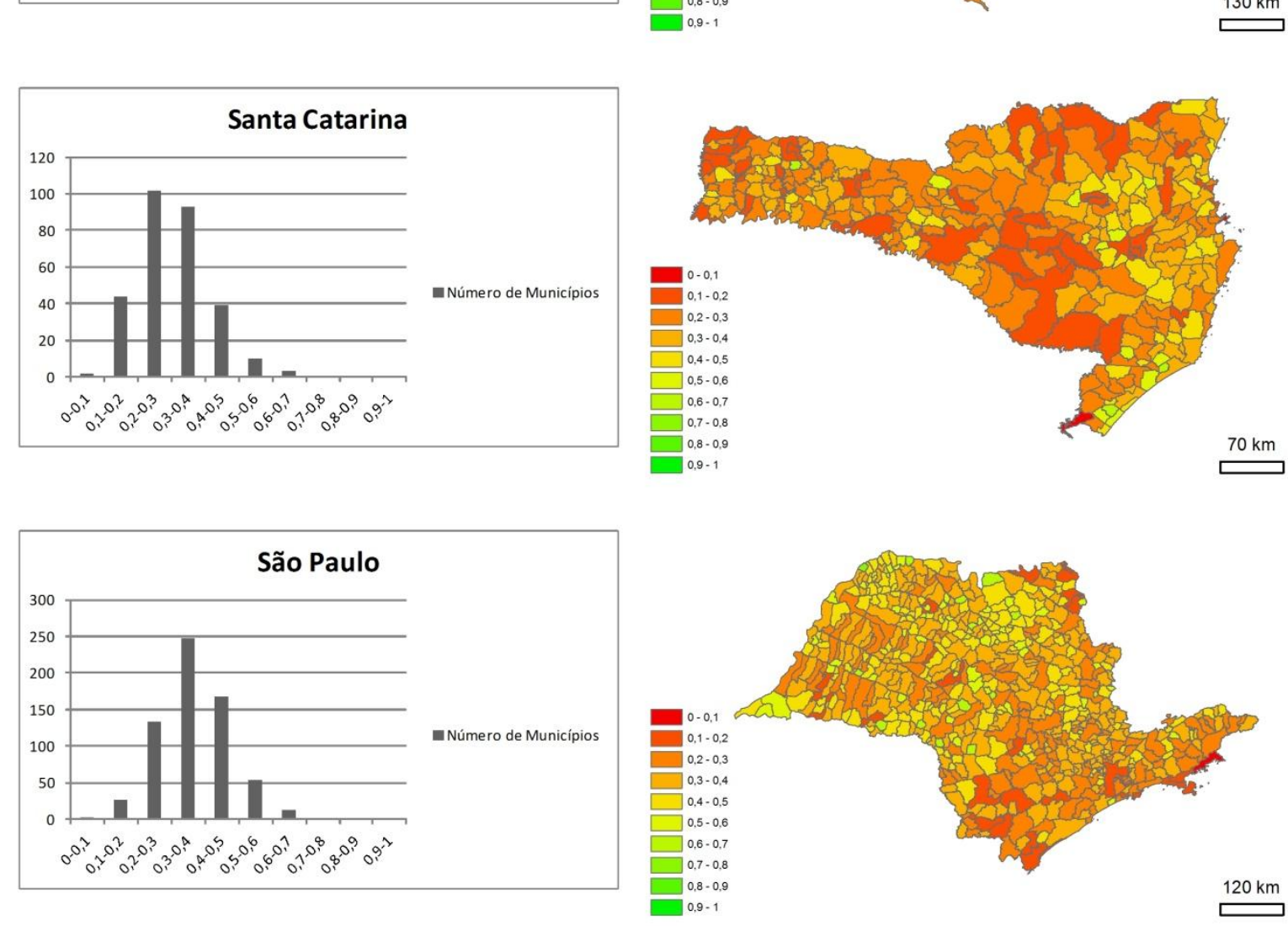

Figura 2.3-9 - Índice de Circularidade dos municípios brasileiros - Rondônia, Roraima, Santa Catarina e São Paulo. Fonte: Elaborado pelo autor 

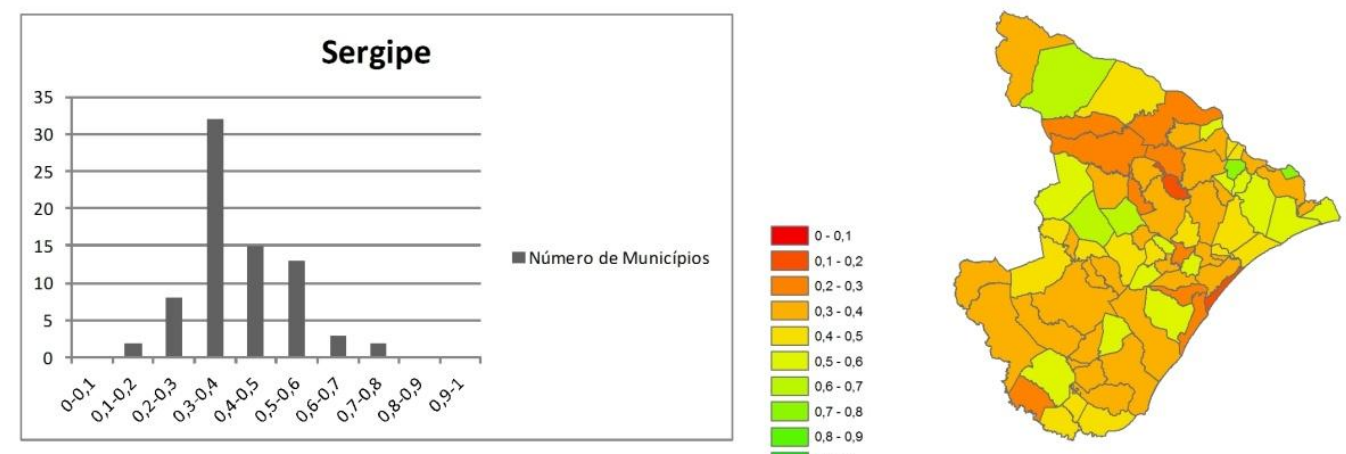

$40 \mathrm{~km}$
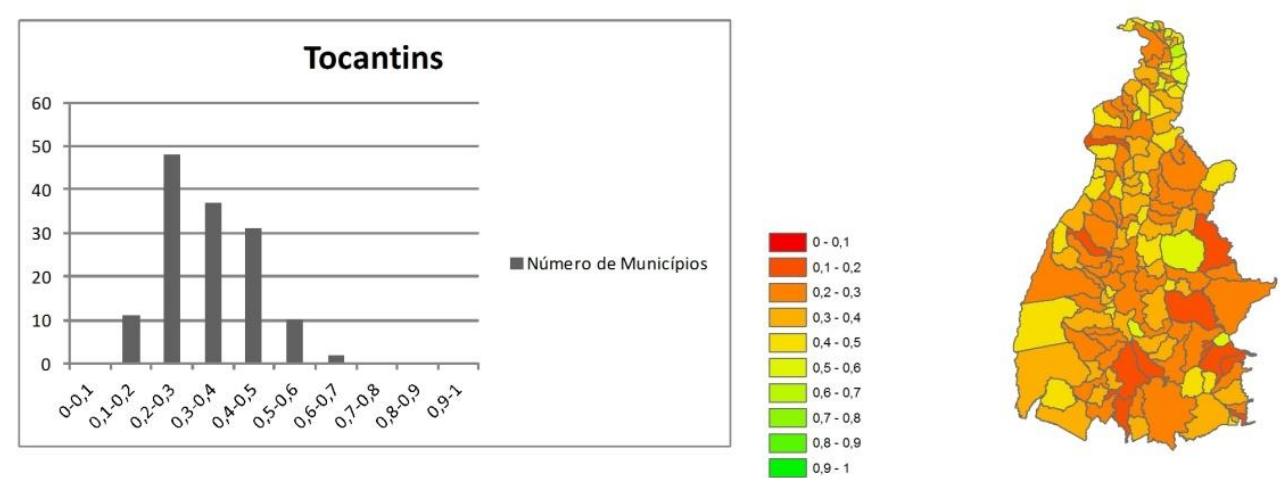

$160 \mathrm{~km}$

Figura 2.3-10 - Índice de Circularidade dos municípios brasileiros - Sergipe e Tocantins. Fonte: Elaborado pelo autor

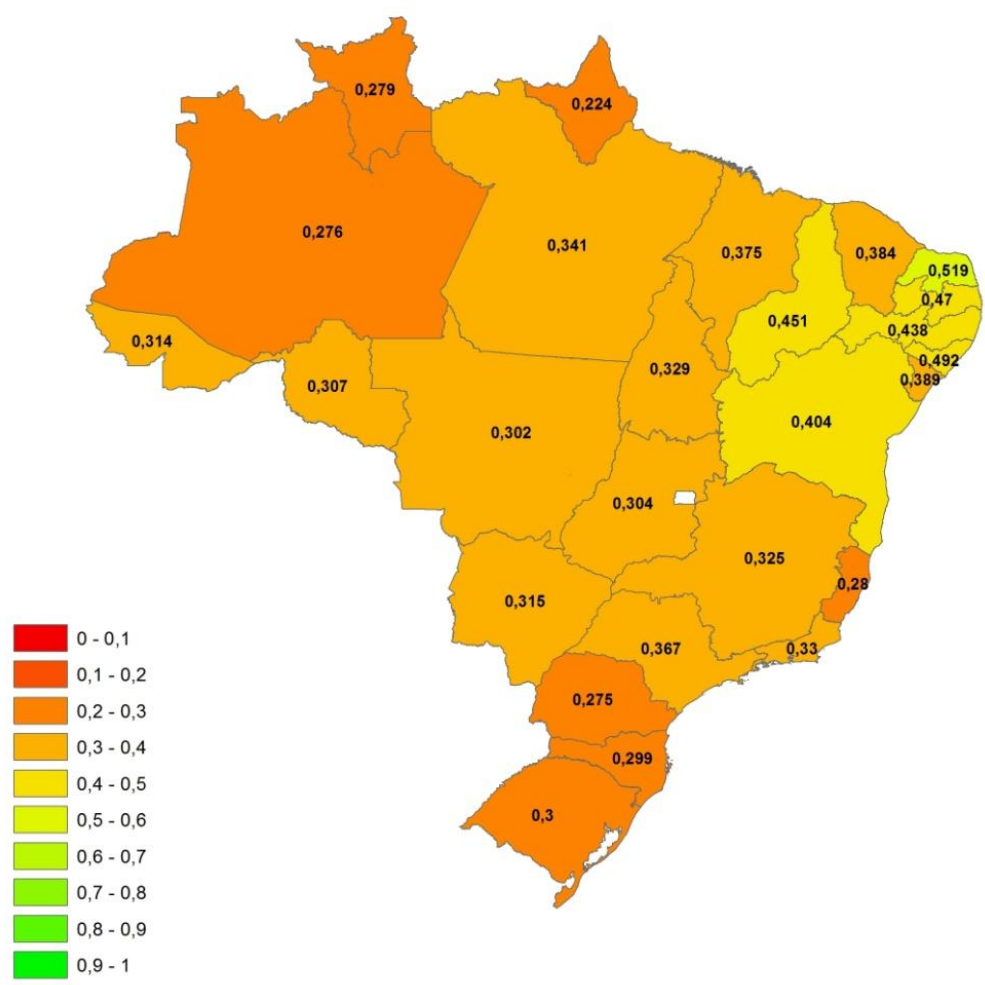

Figura 2.3-11 - Índice de Circularidade dos municípios brasileiros - dados agrupados por estado. Fonte: Elaborado pelo autor 
Dentro deste panorama, seria possível a argumentação de que a não ocorrência do "parâmetro forma" nas legislações direcionadas ao processo de criação e delimitação de municípios poderia contribuir para o negligenciamento da mesma. Mas a simples exigência legal, caracterizada apenas por uma orientação geral, vaga e desprovida de maiores detalhamentos, seria o suficiente para a garantia de formas mais compactas? A análise dos casos enquadrados neste cenário demonstra que não. Considerando somente os municípios criados nos estados do Acre, Bahia, Goiás, Mato Grosso do Sul e Roraima ${ }^{12}$ após a promulgação das respectivas legislações estaduais citadas anteriormente, os resultados obtidos não diferem substancialmente daqueles encontrados na primeira análise, apresentando considerável variação de classes e mediana de 0,341. (tabela 2.3-1).

Pode-se concluir, dentro do exposto, que a forma geométrica do território, pelo menos em princípio, não se apresenta, dentro da divisão político-administrativa do país, enquanto um critério perceptível de orientação prática. Além disso, se já existem dificuldades mesmo com a adoção de parâmetros fixos de forma, textos legais generalistas, tal qual a simples utilização de termos como "formas harmônicas", não garantem - e não garantiram - resultados reais efetivos.

\footnotetext{
${ }^{12}$ O estado do Rio Grande do Sul não foi considerado uma vez que nenhum município foi criado no período compreendido entre a promulgação de sua última lei direcionada a temática da malha municipal (Lei Complementar no 13.535, de 5 de novembro de 2010) e a redação final deste capítulo.
} 
Tabela 2.3-1 - Índice de Circularidade dos municípios criados sob exigências legais referentes às formas territoriais

\begin{tabular}{|c|c|c|}
\hline Estado & Município & Índice de Circularidade \\
\hline \multirow{10}{*}{$\mathrm{AC}$} & Acrelândia & 0,357 \\
\hline & Bujari & 0,32 \\
\hline & Capixaba & 0,327 \\
\hline & Epitaciolândia & 0,331 \\
\hline & Jordão & 0,252 \\
\hline & Marechal Thaumaturgo & 0,399 \\
\hline & Porto Acre & 0,387 \\
\hline & Porto Walter & 0,42 \\
\hline & Rodrigues Alves & 0,256 \\
\hline & Santa Rosa Do Purus & 0,126 \\
\hline \multirow{2}{*}{ BA } & Barrocas & 0,495 \\
\hline & Luís Eduardo Magalhães & 0,579 \\
\hline \multirow{34}{*}{ GO } & Abadia de Goiás & 0,459 \\
\hline & Águas Lindas de Goiás & 0,408 \\
\hline & Alto Horizonte & 0,378 \\
\hline & Amaralina & 0,152 \\
\hline & Aparecida do Rio Doce & 0,408 \\
\hline & Bonópolis & 0,234 \\
\hline & Buriti de Goiás & 0,38 \\
\hline & Buritinópolis & 0,281 \\
\hline & Caldazinha & 0,294 \\
\hline & Campo Limpo de Goiás & 0,577 \\
\hline & Castelândia & 0,192 \\
\hline & Chapadão do Céu & 0,348 \\
\hline & Cidade Ocidental & 0,43 \\
\hline & Gameleira de Goiás & 0,322 \\
\hline & Guaraíta & 0,407 \\
\hline & Inaciolândia & 0,538 \\
\hline & Ipiranga de Goiás & 0,488 \\
\hline & Jesúpolis & 0,44 \\
\hline & Lagoa Santa & 0,394 \\
\hline & Montividiu do Norte & 0,231 \\
\hline & Nova Iguaçu de Goiás & 0,283 \\
\hline & Novo Gama & 0,641 \\
\hline & Perolândia & 0,276 \\
\hline & Porteirão & 0,331 \\
\hline & Professor Jamil & 0,226 \\
\hline & Santa Rita do Novo Destino & 0,183 \\
\hline & Santo Antônio da Barra & 0,426 \\
\hline & Santo Antônio de Goiás & 0,454 \\
\hline & São Patrício & 0,418 \\
\hline & Terezópolis de Goiás & 0,35 \\
\hline & Uirapuru & 0,262 \\
\hline & Valparaíso de Goiás & 0,585 \\
\hline & Vila Boa & 0,196 \\
\hline & Vila Propício & 0,278 \\
\hline \multirow{6}{*}{ MS } & Alcinópolis & 0,277 \\
\hline & Figueirão & 0,4 \\
\hline & Japorã & 0,341 \\
\hline & Laguna Carapã & 0,242 \\
\hline & Nova Alvorada do Sul & 0,202 \\
\hline & Novo Horizonte do Sul & 0,447 \\
\hline \multirow{7}{*}{ RR } & Amajari & 0,141 \\
\hline & Cantá & 0,414 \\
\hline & Caroebe & 0,534 \\
\hline & Iracema & 0,192 \\
\hline & Pacaraima & 0,23 \\
\hline & Rorainópolis & 0,279 \\
\hline & Uiramutã & 0,268 \\
\hline Total/Mediana & 59 & 0,341 \\
\hline
\end{tabular}

Fonte: Elaborado pelo autor 


\title{
2.4. OS DISTRITOS E OS LIMITES HERDADOS
}

Segundo Meirelles (1981), a forma usual de criação de municípios é a emancipação de distritos. No Brasil, embora a totalidade dos municípios existentes não tenha surgido mediante processos emancipatórios de antigas áreas distritais, a grande maioria, sem sombra de dúvidas, apresentou esta etapa em sua evolução político-administrativa. Assim sendo, o estudo territorial do município não pode deixar de se atentar para a relevância dos distritos, "embriões" políticos e territoriais da entidade municipal.

Pode-se, em um primeiro momento, optar pela análise do distrito sob um viés jurídico. Neste cenário, o mesmo pode ser entendido enquanto uma divisão meramente administrativa do município, não constituindo pessoa jurídica, tampouco apresentando autonomia política ou financeira. A área distrital seria caracterizada apenas pela ocorrência de alguns serviços públicos tanto de caráter estadual (posto policial, agência dos Correios, etc.) como de caráter municipal (limpeza pública, conservação de estradas, velório/cemitério, etc.) (MEIRELLES, 1981). Segundo Pinto (2003):

\begin{abstract}
o distrito é uma subdivisão do município, que tem como sede a vila, que é um povoado de maior concentração populacional. Ele não tem organização da pequena produção e atendimento das primeiras necessidades da população residente em seu entorno, cujo comando fica a cargo da sede do município. O distrito tem a mesma denominação de sua vila e, somente pode ser criado por meio de lei municipal. No entanto, os requisitos exigidos para a criação de um distrito são estabelecidos por meio de lei estadual. $\mathrm{O}$ município não pode, por si só, instalar distritos adotando critérios próprios. Faz-se necessário que um povoado atenda todas as exigências determinadas pela legislação estadual para que o município, por meio de uma lei municipal aprovada pela Câmara de Vereadores local, o eleve à categoria de distrito. (PINTO, 2003)
\end{abstract}

O distrito pode, entretanto, ser entendido mediante um segundo tipo de análise, de caráter mais qualitativo, atrelado a aspectos sociais, econômicos e políticos. Os estudos de Brandão (2009), realizados no município paulista de São Luiz do Paraitinga, por exemplo, apontam para a vila (a sede distrital) como um elemento de conexão entre os ambientes rural e urbano. Esta, antecedida pelo sertão (área não habitada; local de absoluta natureza) e pelo bairro rural (local de convergência do trabalho camponês e da passagem da vida familiar existentes nos 
sítios para a vida comunitária) dentro da consideração de uma hierarquia dos espaços vividos e percebidos no cotidiano de uma sociedade rural, seria caracterizada pela ocorrência de algumas características urbanas em um antigo bairro rural, uma espécie de "lenta construção da cidade sobre o bairro" (BRANDÃO, 2009).

\begin{abstract}
De algum modo a vila está para a cidade assim como o sertão está para o bairro. Um representa a transformação do outro e, ao mesmo tempo, o limite da sua realização. Ora, num passado não tão remoto, a própria cidade de São Luís do Paraitinga foi há algum tempo o "Sertão do Paraitinga" e, Catuçaba foi, primeiro fazenda e, depois, o "Bairro de São Pedro". A vila é o lugar para onde convergem os bairros de perto, às vezes, ditos em conjunto: "os bairros de Catuçaba". Assim como os vários bairros são vistos, um a um, como uma conquista do trabalho sobre o sertão - poderoso ainda, mas agora acuado - assim também a vila é percebida como o desdobramento do bairro e uma espécie de conquista da cidade sobre ele. Fora crianças, todos os moradores de Catuçaba vieram dos bairros. Fora alguns adultos e quase todos os velhos, as pessoas do lugar antecipam na cidade o seu destino. Por isso, lugar simbólico entre o bairro e a cidade, a vila é também o lugar social da passagem da vida de um à outra. (BRANDÃO, 2009)
\end{abstract}

\begin{abstract}
Plenamente dependente da atividade agropastoril e habitada por pessoas que direta ou indiretamente estão mergulhadas em um mundo de feijão e milho, gado e leite, a vila é um bairro rural que se tornou urbano. Sua principal característica: deixou de ser um concentrado esparso de terrenos separados uns dos outros por suas cercas de arame para ser um concentrado de casas unidas umas às outras, parede com parede. No entanto, sentem as pessoas do povoado que a continuidade, aqui, entre o urbano e o plenamente rural, é muito maior do que na cidade que realiza o urbano, mesmo quando sua economia direta é totalmente agropastoril, como é o caso de São Luís do Paraitinga. Pequeno povoado entre riachos, morros e pastos, basta caminhar alguns metros a pé em qualquer direção para já se estar no que se considera alguns dos bairros de perto. (BRANDÃO, 2009)
\end{abstract}

Ainda dentro da hierarquia espacial apresentada pelo referido autor, vila e cidade não poderiam ser colocadas sob um mesmo patamar devido a diferenças substanciais entre as mesmas. Em um primeiro momento, deve-se atentar para a existência de uma dominação política de uma sobre a outra. A vila, embora qualificada como sede da vida social, não possuiria o "poder de sociedade", (elemento que constituiria a cidade e o sue domínio sobre o campo), estando atrelada obrigatoriamente aos "desmandos" oriundos da cidade. Além disso, a comparação se tornaria ainda mais complicada caso o fator dimensão fosse levado em conta. O tamanho e os recursos distritais não estariam em condições de 
"competição" com a cidade, o local das trocas, de existência de maiores recursos e de oferta dos serviços básicos e centrais; o local de destino e referência.

Pina et al (2008), partindo de uma contextualização similar de inserção do distrito entre o rural e o urbano, apresentaria situação semelhante no que tange a relação existente entre a vila e a cidade. A questão da influência, entretanto, poderia ser relativizada e diferenciada em dois tipos de estado de dependência, um absoluto e outro relativo. Enquanto o primeiro poderia ser caracterizado por uma situação em que a sede do distrito-sede (a cidade) correspondesse efetivamente ao centro político e econômico do município, o segundo surgiria em situações em que a vila, embora dotada de relativa autonomia econômica, não pudesse ser taxada de cidade simplesmente pelo fato de não corresponder a uma sede municipal (PINTO apud PINA et al, 2008). Em suma, uma total dependência, tanto econômica como política, ou uma independência no campo da economia em contrapartida a uma "amarração" política e jurídica.

A consideração deste cenário em meio à temática dos limites territoriais permite, por sua vez, a identificação de uma questão-chave, embora pouco discutida, diretamente relacionada a muitos dos problemas e litígios ligados ao território comumente existentes em âmbito municipal: a simples transformação dos limites distritais em limites intermunicipais.

Dentro do conjunto de leis estaduais levantadas, a orientação para a utilização de "limites pré-existentes" ocorre especificamente nos estados de Pernambuco, Rio Grande do Sul, Roraima e Santa Catarina, configurando-se enquanto exigência de manutenção do território distrital no processo de criação de um município, como no caso pernambucano, ou na preferência pela adoção de limites distritais já existentes, como nos demais casos. Mesmo que explicitado somente nas quatro legislações citadas, a herança da configuração territorial no processo de emancipação de distritos e criação de municípios se apresenta como uma prática corriqueira no círculo político nacional, diretamente relacionada à própria tradição do país no estabelecimento de suas fronteiras externas, bem como a uma tendência consolidada historicamente no direito internacional.

Segundo Casella (2009), o Tratado de Madri (1750), responsável pela substituição da configuração territorial acordada entre Espanha e Portugal pelo Tratado de Tordesilhas (1494), deu início ao período de consolidação e fixação do 
princípio do uti possidetis no direito internacional (ou mais especificamente no direito das fronteiras). Este, caracterizado pela legitimação legal da posse efetiva sobre arguições de natureza jurídicas, ou seja, pela "validação" dos limites das áreas sob as quais a posse era indiscutível enquanto fronteiras entre estados litigantes, abrindo-se mão, desta forma, de qualquer tipo de acordo pré-existente, seria posteriormente utilizado na solução de quase todas as questões fronteiriças do Brasil com os seus países vizinhos, tornando-se, assim, um marco na diplomacia brasileira no que tange a temática dos limites. Além disso, também seria empregado em todo o contexto de descolonização nas Américas (desde o século XIX) e na África (a partir da segunda metade do século $\mathrm{XX}$ ), dando origem a outro princípio jurídico fortemente aceito na atualidade: o princípio da intangibilidade das fronteiras. Dentro deste, os novos países, surgidos a partir da independência de antigas colônias, deveriam, como forma de garantir a estabilidade política e evitar conflitos de secessão, respeitar as antigas fronteiras coloniais como os limites do território nacional.

Sendo este o panorama internacional, aquilo que ocorre em âmbito nacional é uma espécie de sua reprodução. Como forma de se evitar o embate entre distintos interesses, muitas vezes representados pelo poder municipal, opta-se pela solução mais simples do ponto de vista político, relegando o ônus da perda de território e, consequentemente, de recursos, apenas para o município-mãe do distrito a ser emancipado. A simples transposição dos limites distritais para o novo município apresenta, entretanto, um grave problema. A passagem de status, de distrito para município, ocorre em meio à desconsideração das alterações espaciais ocorridas (e que irão ocorrer) com a mesma. A transformação da vila em cidade, ao extinguir a relação de dependência, seja ela relativa ou absoluta, modifica, mesmo que não instantaneamente, a dinâmica local e, por consequência, a dinâmica regional. Conforme aponta Castro et al (2013), embora o lugar físico seja mantido, altera-se a forma como se encara o referido território, modificando sua posição econômica, social e política. Assim sendo, se a sede distrital e a sede municipal não possuem a mesma dimensão - possivelmente econômica e certamente política - qual seria a eficácia ou racionalidade da estrita transferência dos antigos limites distritais para o novo território municipal? As respectivas áreas de influência ${ }^{13}$ seriam exatamente

\footnotetext{
${ }^{13}$ Uma melhor discussão sobre áreas de influência pode ser encontrada no capítulo 3.
} 
iguais? Estes dois tipos de limite seriam correspondentes no que tange a sua relevância e as suas funções?

Tomemos um caso de análise específico como forma de exemplificar concretamente a problemática exposta: a vila de Engenheiro Maia, localizada no município paulista de Itaberá. Antigo loteamento existente nas proximidades da estação homônima da Estrada de Ferro Sorocabana, o bairro de Engenheiro Maia seria "alvo" de um processo de emancipação iniciado na década de 90 do século passado. O requerimento enviado à Assembleia Legislativa do Estado de São Paulo - ALESP (Processo RG 2613/94), de autoria do Movimento Pró-Emancipação de Engenheiro Maia, no que tange aos limites territoriais, apesar de não conter uma proposta tecnicamente mais elaborada, já apresentava um croqui com um esboço do contorno pretendido/imaginado para o território do novo município (figura 2.4-1), o qual abarcaria áreas dos municípios de Itaberá, Itararé e Itapeva.

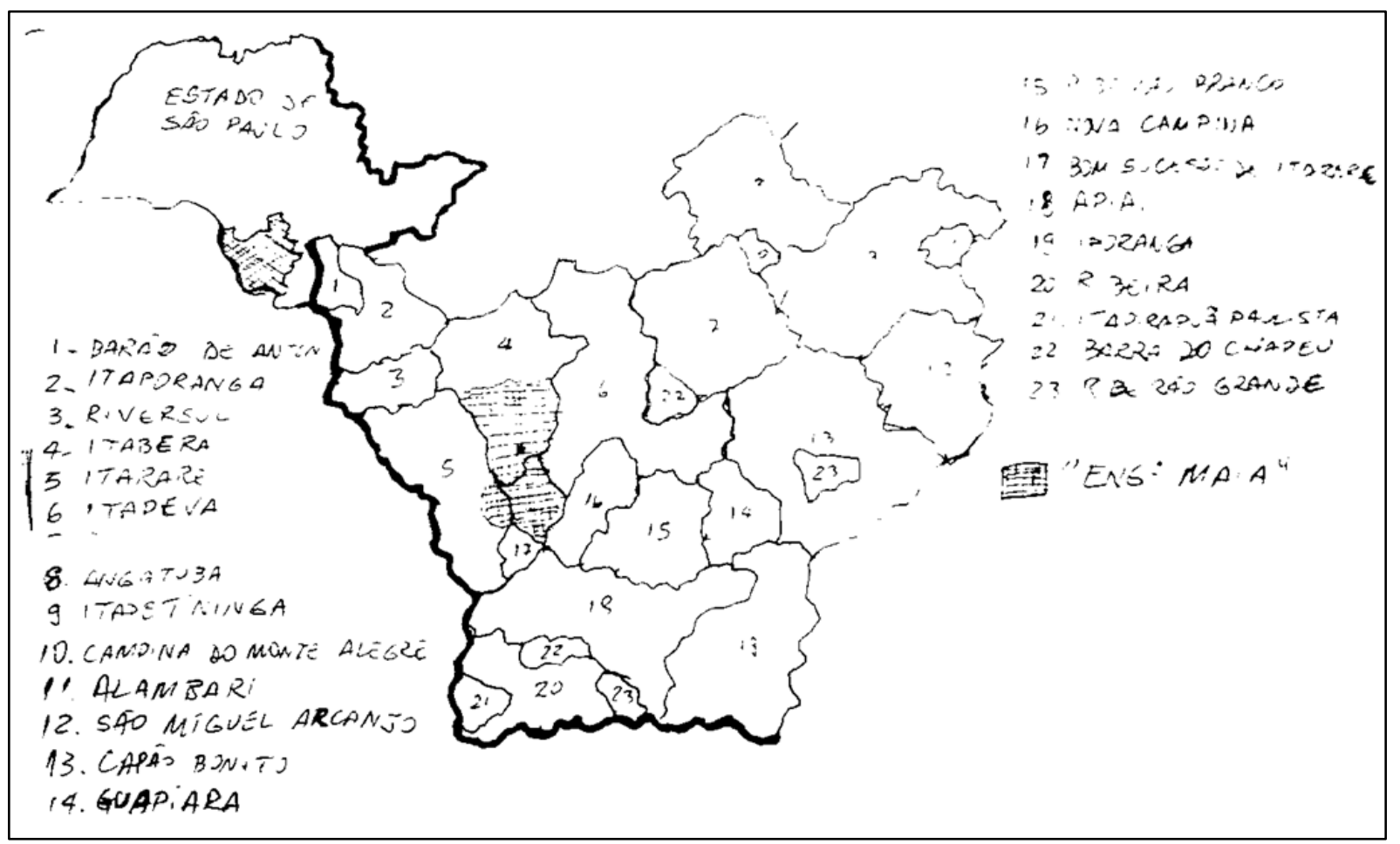

Figura 2.4-1 - Croqui dos limites territoriais propostos para o Município de Engenheiro Maia. Fonte: Processo RG 2613/94 - ALESP 
De forma subsequente, ainda em 1994, seria solicitado um parecer técnico via Comissão de Assuntos Municipais da ALESP - do Instituto Geográfico e Cartográfico (IGC), órgão estadual competente, referente à contemplação dos requisitos legais para a criação do pretendido município. A Informação Técnica 44/94, elaborada pela Divisão de Apoio Técnico à Divisão Administrativa e Territorial (DAT) do referido órgão, além de não comportar objeções para a efetivação da emancipação de Engenheiro Maia, também apresentaria uma descrição sistemática - aliada a uma representação cartográfica - dos limites propostos para o futuro município (figura 2.4-2). Nesta, apenas os municípios de Itaberá e Itapeva seriam "atingidos".

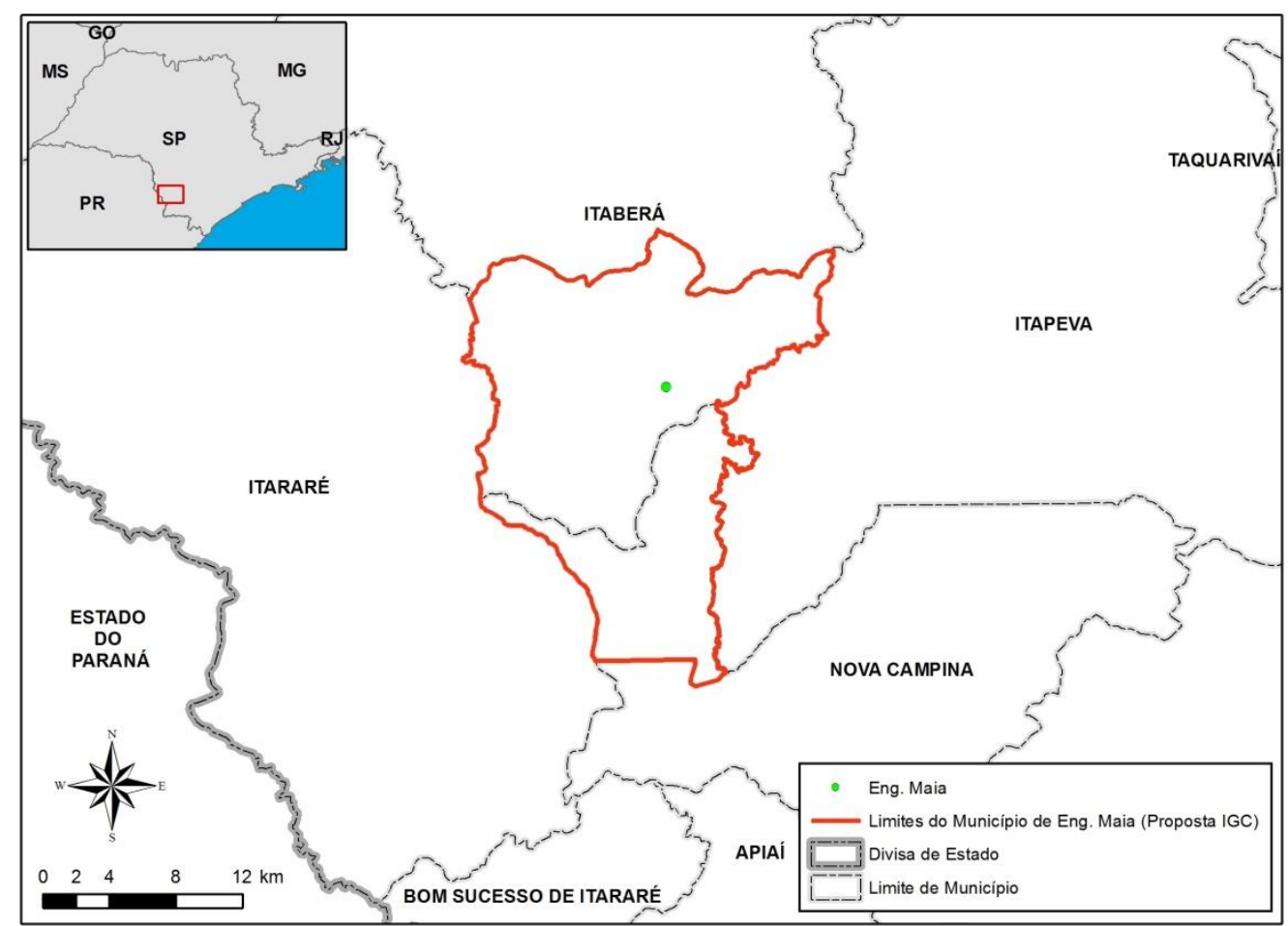

Figura 2.4-2 - Limites do Município de Eng. Maia (Proposta IGC)

Fonte: Elaborado pelo autor

Por fim, dois anos após o início de todo o processo, e sem a ocorrência da criação do Município de Engenheiro Maia ${ }^{14}$, o Município de Itaberá, através da Lei Municipal $n^{\circ}$ 1.605, de 6 de março de 1996, criaria o distrito de Engenheiro Maia, o qual teria seus limites territoriais estabelecidos quase uma década depois, mediante a promulgação da Lei Municipal n 1.959, de 10 de março de 2004 (figura 2.4-3).

\footnotetext{
${ }^{14} \mathrm{~A}$ área pretendida para o novo município não apresentou o número mínimo de eleitores exigidos por lei (1.000 eleitores de acordo com a Lei Complementar Estadual n 651/90).
} 
Têm-se assim três propostas distintas para um território centrado em uma mesma sede. A primeira, indubitavelmente inferior no aspecto técnico, apresenta uma área identificada sob a ótica dos próprios moradores locais, podendo ser caracterizada tanto como uma percepção cotidiana da efetiva área de influência do bairro, como pela espacialização de interesses, particulares ou coletivos, existentes sob o pedido de emancipação. A segunda, proveniente de um orgão técnico, propõe um desenho territorial resultante de estudos e verificações realizados em campo, aparentemente dotados de procedimentos metodológicos pré-estabelecidos, embora não explicitados. A terceira, por sua vez, resulta do "recorte" da proposta do IGC de acordo com os limites itaberaenses, haja vista que o distrito, atrelado juridicamente à Itaberá, não poderia abarcar áreas de municípios vizinhos.

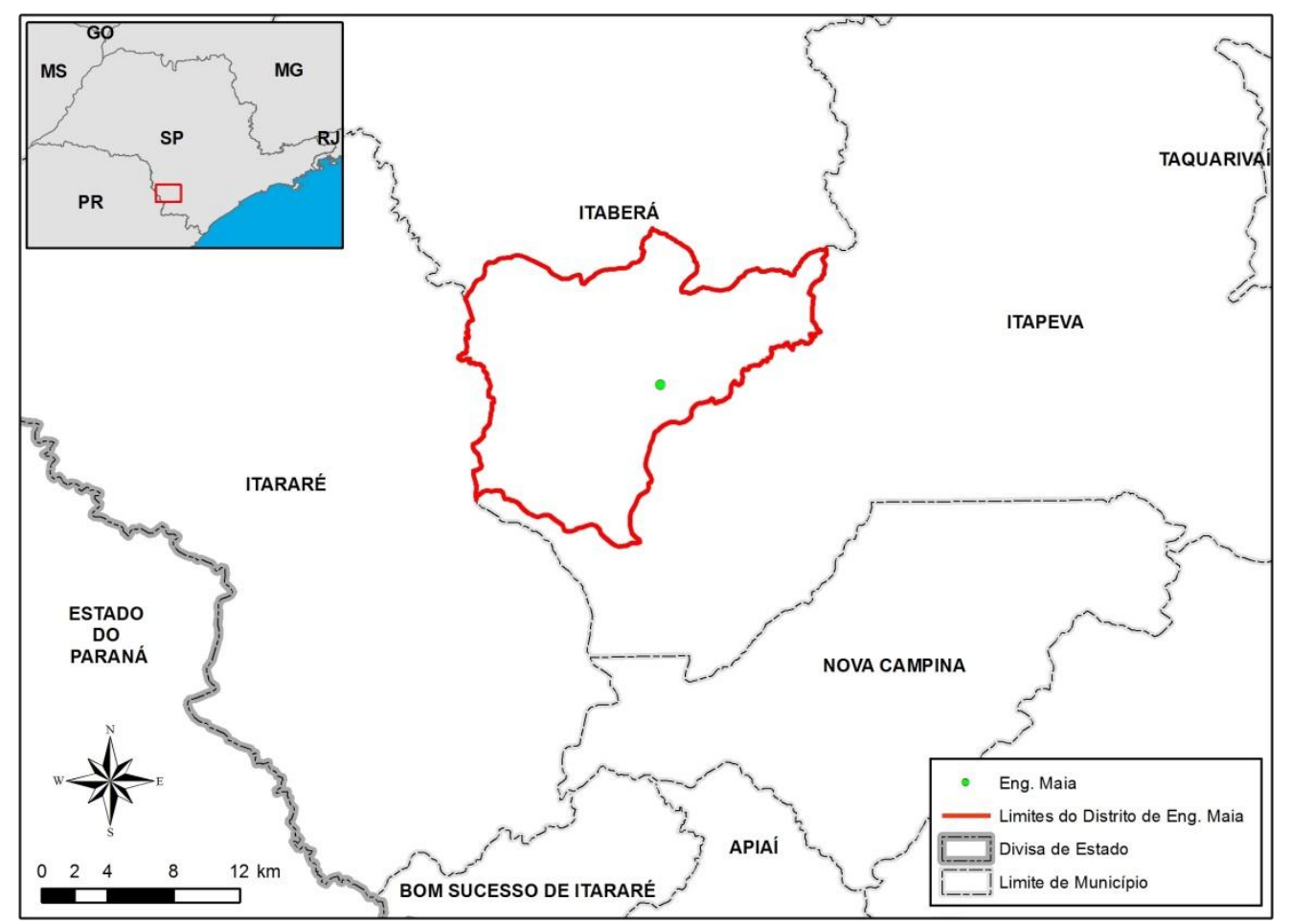

Figura 2.4-3 - Limites do Distrito de Eng. Maia

Fonte: Elaborado pelo autor

Dentro do exposto, levando em consideração uma possível retomada do movimento de emancipação de Engenheiro Maia (com a correlata contemplação dos requisitos legais), torna-se possível a indagação a respeito de qual proposta de delimitação seria utilizada para a configuração territorial do novo município. Neste 
momento, a problemática da herança dos limites torna-se evidente. Descartando a proposição original, notadamente simplória e inconsistente, tem-se o "embate" entre uma construção de cunho técnico, atrelada a um reconhecimento da real área de influência do núcleo de Engenheiro Maia, e uma construção de caráter predominantemente político, originada de um ajuste territorial juridicamente necessário no momento da criação do citado distrito. Partindo da constatação de que a emancipação de áreas distritais ocorre, seja por exigências legais, seja pela conivência política (uma vez que não envolveria interesses de outra administração municipal), mediante a manutenção de seus limites, pode-se esperar, de forma quase que inequívoca, que o território do pretenso Município de Engenheiro Maia corresponderia ao mesmo do distrito homônimo. Configurar-se-á, desta forma, uma situação de desconsideração das relações locais e regionais teoricamente identificadas no estudo do orgão estadual competente. 


\section{CIRCULAC̄̃̃O: UM PARÂMETRO POSSÍVEL PARA A DELIMITACÃO}

\section{TERRITORIAL DE MUNICÍPIOS}

A análise crítica do atual processo de delimitação territorial de municípios no Brasil, desenvolvida no capítulo anterior, apesar de já representar um esforço acadêmico de pesquisa considerável, principalmente no que tange a falta de trabalhos do gênero, não se constitui, entretanto, como o elemento central deste estudo. Na verdade, todo o levantamento histórico da legislação, bem como dos conceitos teóricos e práticos atrelados aos elementos contidas na mesma, "apenas" serviram para corroborar com um entendimento prévio da problemática dos limites intermunicipais. O grande desafio aqui presente não é o simples apontamento de problemas, uma espécie de crítica pela crítica - como se pode facilmente encontrar em inúmeros trabalhos atuais em Geografia - mas a busca de uma solução coerente, atual e efetiva para esse vazio teórico e técnico encontrado. Neste momento surgem as indagações centrais deste raciocínio: Se cabe aos geógrafos delimitar o espaço, como os mesmos deveriam proceder em uma situação real de estabelecimento de uma linha limítrofe entre municípios? Quais parâmetros e critérios devem ser considerados para uma delimitação territorial realmente eficiente?

A caminhada para estas respostas, por sua vez, também apresenta questionamentos em seu "pontapé inicial". Se é pretendido definir um território para um tipo de unidade político-administrativa específica, no caso o município, qual seria então, o nosso entendimento a respeito do significado e das funções da entidade municipal?

Em um primeiro momento, poderíamos recorrer a definições técnicas de município. Vejamos duas:

Divisão administrativa de origem romana, levada pelos romanos para a Península Ibérica, e de Portugal trazida para o Brasil; equivalente a vila; menor unidade territorial político-administrativa autônoma; entre os antigos romanos, cidade que possuía o direito de se administrar e governar por suas próprias leis; substitui definitivamente o termo "vila" a partir da República, tendo aparecido pela primeira vez na legislação brasileira através da Carta Régia de 29/10/1700. (IGC, 1995) 
São as unidades de menor hierarquia dentro da organização políticoadministrativa do Brasil, criadas através de leis ordinárias das Assembléias Legislativas de cada Unidade da Federação e sancionadas pelo Governador. No caso dos territórios, a criação dos municípios se dá através de lei da Presidência da República. (IBGE, 1998)

Aqui, embora possamos identificar, a partir das duas definições expostas, que o município é a menor unidade autônoma na hierarquia político-administrativa nacional, pode-se afirmar que a mera definição descritiva ainda não torna possível uma resposta para o nosso questionamento inicial acerca de seu significado funcional. Constatar que o município compõe a federação brasileira juntamente com a União e os estados não é suficiente. É preciso ter em vista, mesmo que de forma breve, a sua própria concepção histórica e o seu atual significado na prática.

De acordo com Meirelles (1981), o município, enquanto unidade políticoadministrativa, teria surgido durante a República Romana, como forma de manutenção da dominação pacífica das áreas conquistadas militarmente. Para tal, em troca de obediência e sujeição, eram garantidos a estes locais relativos direitos privados e privilégios políticos, caracterizados por uma certa autonomia da administração local representada pela eleição dos próprios governantes. No ano de 709, mediante a lei Lex Julia Municipalis, o sistema de governo municipal seria estendido para algumas províncias do império, dentre as quais estava a região da Península Ibérica. Posteriormente, durante a colonização do Brasil por Portugal, o município seria transplantado para a organização política, administrativa e judiciária da colônia.

Ainda segundo o autor, o município no mundo moderno, diferentemente de sua origem romana, seria caracterizado por uma diversificação em sua estrutura e em suas atribuições, apresentando variações em sua autonomia de acordo com a regulação interna dos países em que está presente. Mesmo assim, seria inegável o papel atual do município em questões cruciais, tais quais a ordenação urbana e a organização dos serviços públicos locais. (MEIRELLES, 1981).

A afirmação de Temer apud Giglio (2001) de que "é nos municípios que os cidadãos moram e trabalham" nos parece emblemática. O município é, efetivamente, o local onde o nosso cotidiano ocorre, uma espécie de "palco da vida", nos termos de uma recente publicação da Confederação Nacional dos Municípios (CNM), ou simplesmente o "espaço mais banal e mais fundamental da nossa sociedade" nas 
palavras de Castro (2003). Neste cenário, serviços públicos básicos estão diretamente atrelados ao governo municipal, sejam eles nas áreas de educação, saúde, transporte, infraestrutura, etc. Os próprios dados apresentados por Giglio (1998) corroboram com esta percepção: em pesquisa de opinião pública realizada em 1997 a respeito das diferentes esferas de governo, 55\% dos entrevistados afirmaram serem as prefeituras as mais importantes no seu dia-a-dia (em detrimento de $19 \%$ do governo federal e $15 \%$ dos governos estaduais).

O município constitui-se, assim, como uma forma de descentralização do Estado, tanto para propósitos políticos como para fins administrativos. Ao mesmo tempo em que contribui para a consolidação de um poder nacional, regional e local dentro de uma lógica de "dividir para reinar", também representa uma forma de acesso mais direto e simples aos serviços públicos mais essenciais por parte da população. Este é o primeiro ponto.

Outra análise necessária deve ser iniciada com a diferenciação entre município e cidade, comumente tratados enquanto sinônimos. Definida pelo IBGE (1998) como "localidade com o mesmo nome do município a que pertence (sede municipal) e onde está sediada a respectiva prefeitura, excluídos os municípios das capitais.", a cidade nada mais é do que a sede do município, normalmente correspondente à área urbana do mesmo. Desta forma, o município contém a cidade, sendo composto pela "soma" desta com a área rural municipal ${ }^{15}$.

Neste caso, temos novamente uma interpretação, assim como a de município, centrada simplesmente na hierarquia da divisão político-administrativa do país. Um entendimento a partir de uma perspectiva mais funcional e menos "burocrática", pode, entretanto, ser encontrado na Teoria dos Lugares Centrais de Walter Christaller, a qual, segundo Gama (1983), deve ser entendida como uma tentativa teórica de explicação, de caráter generalizante, da configuração espacial do povoamento, buscando verificar a existência de leis que determinam o número, o tamanho e a distribuição das cidades, considerando os distintos graus de centralidade e as respectivas regiões de influência de um determinado conjunto de centros. Aqui, fazemos uma pausa em nosso desenvolvimento anterior para uma maior explanação da teoria de Christaller.

\footnotetext{
${ }^{15}$ Casos em que a área da sede municipal (cidade) corresponde exatamente a área do município não havendo área rural desta forma - embora existam, são notadamente exceções no Brasil, concentrando-se basicamente nas regiões metropolitanas.
} 
De fato, a intenção inicial seria demonstrar que a organização das cidades não apresentava uma desordem, pelo contrário, evidenciava uma disposição regular e a existência de uma hierarquia. Além disso, buscava-se evidenciar que a relação entre a dimensão de cada centro e a superfície dos territórios que as serviam era direta. O modelo estático apresentado seria, em princípio, oriundo de observações do comportamento das pessoas perante a oferta de bens e serviços (ABLAS, 1982).

Inicialmente, devem-se ser destacadas as ideias de ordem e centralidade, utilizadas, segundo Gama (1983), como ponto de partida para a reflexão sobre o significado do povoamento. A organização entorno de um núcleo seria apresentada como um fenômeno natural, presente tanto nas atividades humanas como em diversas relações existentes na natureza.

\begin{abstract}
A cristalização da massa em volta de um núcleo é, na natureza inorgânica como na orgânica, uma forma elementar da ordem das coisas, as quais se inter-relacionam ao mesmo tempo - uma ordem centralista. Esta ordem não é apenas um modo de pensar...; existe de fato exteriormente aos padrões da matéria. (CHRISTALLER apud GAMA, 1983)
\end{abstract}

Segundo Ablas (1982), no que tange a organização do homem, a vida comunitária apresentaria, ao longo do tempo, exemplos práticos desta consideração. Entrepostos comerciais, igrejas, fazendas, entroncamentos viários, etc. representariam fenômenos de corroboração ao pensamento de Christaller. Para o mesmo, o burgo medieval, caracterizado por uma praça central, local do mercado, rodeada por residências e dotada dos principais serviços locais, públicos e particulares, seria outro exemplo da organização concêntrica argumentada pelo geógrafo alemão.

Neste contexto, a própria cidade confirmaria a ideia inicial, tanto no plano interno como no externo. Internamente, a sua aparente desorganização seria superada pelo reconhecimento de locais nos quais a vida urbana ocorreria de forma mais intensa. A expansão do princípio de centralidade para o espaço exterior à cidade, por sua vez, torna possível a caracterização da mesma como um núcleo central capaz de cumprir determinadas funções em proveito de sua região complementar (ABLAS, 1982). 
Não analisaremos o fenômeno completo da "cidade", mas apenas aquela característica definida que é decididamente importante para o conceito de "cidade" e para a geografia das localidades. Trata-se do que Gradmann denominou "a principal vocação" de uma cidade, a saber, "ser o centro de seus arredores rurais e mediadora do comércio local com o mundo exterior. (CHRISTALLER apud EUFRÁSIO, 1981)

Surgiria assim a ideia de lugar central, caracterizado como um local de concentração de população e atividades econômicas em comparação com o seu entorno, com a sua região complementar, área esta com ocorrência dispersa de pessoas e serviços, normalmente caracterizada pelo predomínio de atividades agrícolas. O conjunto dos lugares centrais não apresentaria, todavia, uma situação equilibrada e homogênea, pelo contrário, seria definido por uma hierarquia entre os distintos centros.

Para Christaller o lugar central pode ter diversos tamanhos e ser complementar a regiões da mesma forma maiores ou menores. Com isso ele introduz uma ideia de diferenciação por níveis dos lugares centrais, sendo possível falar em lugar central de primeira ordem, de segunda ordem e assim por diante. (ABLAS, 1982)

Os lugares que têm funções centrais que se estendem sobre uma vasta região, em que existem outros lugares centrais de menor importância, são chamados "lugares centrais de ordem mais elevada". Os que tem apenas importância central local para os arredores imediatos são chamados correspondentes de "lugares centrais de ordem mais baixa" e "da ordem mais baixa". Os lugares menores que usualmente não tem importância central, mas que todavia exercem muito poucas funções centrais são chamados "lugares centrais auxiliares. (CHRISTALLER apud EUFRÁSIO, 1981)

E qual seria a forma de classificar os lugares centrais? Christaller centraria sua análise na definição da importância de cada lugar, a qual, entretanto, não deveria ser mensurada a partir de valores de área e população, usualmente utilizados. Não seria um valor numérico que definiria o grau de importância, mas sim uma condição, de maior viés qualitativo, da oferta, e não da produção, de bens e serviços centrais, responsáveis pelo nível de centralidade, pelo tamanho da região complementar e pela posição na hierarquia dos lugares. Estas funções centrais abarcariam, segundo Ablas (1982), o comércio, naturalmente voltado para o centro, em primeiro lugar, seguido pelos serviços bancários, serviços ligados à 
administração pública, pequenos serviços autônomos, serviços culturais e espirituais.

\begin{abstract}
A "importância" não é uma soma, absolutamente, mas é antes a "atuação conjunta" econômica dos habitantes. Essa "atuação" envolve graus de intensidade, e é algo completamente diferente da mera soma de resultados econômicos singulares. Essa atuação conjunta, que chamaremos de "importância", é o que é referido quando se chama uma cidade "viva", "próspera" ou "importante". (CHRISTALLER apud EUFRÁSIO, 1981)
\end{abstract}

$\mathrm{Na}$ construção teórica de Christaller, é a partir deste momento que a circulação surge como elemento crucial. Dentro disto, em meio aos possíveis fatores decisivos para a formação e consolidação dos lugares centrais, a questão distância seria destacada. De acordo com Ablas (1982), a determinação da magnitude de um lugar central estaria fortemente influenciada pela distribuição da população e por suas distâncias em relação ao centro, preponderantemente calculada pelos fatores custo e tempo de transporte (e não simplesmente pela quilometragem). Neste cenário, melhores condições de tráfego e transporte acarretariam em uma redução da distância temporal e econômica, o que, por sua vez, contribuiria para o aumento da área servida pelo lugar central. Além disso, a circulação nada mais seria que um reflexo de uma relação de troca real, na qual a própria existência das vias apontaria para uma situação de demanda concreta.

Dentre os processos e relações econômicos que levam à formação dos órgãos espaciais e especiais que são os lugares centrais, a distância desempenha um papel muito importante: quanto mais desenvolvido é o sistema econômico, e quanto mais ele opere em economia de mercado, tanto mais decisivo é o fator distância. A esse respeito, a expressão matemática da distância, em metros ou quilômetros, é inteiramente sem importância. Somente a expressão econômica da distância corresponde à importância econômica da distância. Essa "distância econômica" é determinada pelos custos de frete, os custos de seguros, as taxas de armazenagem, o período de tempo, a perda de peso ou espaço devido ao transporte, etc.; e quanto ao transporte de passageiros, o custo do transporte, a duração da viagem e o conforto. (CHRISTALLER apud EUFRÁSIO, 1981)

Essa distância econômica é um elemento muito importante para a determinação do "alcance de um bem", ou seja, a distância mais afastada a que a população dispersa está disposta a ir a fim de comprar um bem oferecido em um lugar - um lugar central. Se a distância é demasiado grande, a população não irá comprar esse bem porque se torna por demais 
caro para ela; ou irá comprá-lo em outro lugar central em que ela possa obtê-lo com uma despesa menor. (CHRISTALLER apud EUFRÁSIO, 1981)

\begin{abstract}
A circulação só em mínima parte é um fator econômico independente; e, essencialmente, é a expressão manifesta de fenômenos e processos econômicos. Estes são os fatores fundamentais e decisivos que determinam a rede de localidades e os locais de produção. A circulação desempenha unicamente um papel de mediação isto é, torna possível uma troca, sempre que a necessidade de tal troca exista. $O$ volume de circulação, a distribuição e o traçado das rotas de circulação correspondem às necessidades de trocas com relação à quantidade e à direção, pelo que, via de regra, a necessidade latente de transporte provoca uma demanda que as rotas de circulação transformam em transporte efetivo. Casos em que a localização da circulação desperta a demanda são raros. (CHRISTALLER apud EUFRÁSIO, 1981)
\end{abstract}

Com a apresentação de seus conceitos-chave concluída, a obra christalliana chegaria enfim a um modelo teórico de organização das cidades. Adotando-se um cenário ideal, sem qualquer tipo de obstáculo ao transporte e com possibilidades de deslocamento em todas as direções, além de custos homogêneos em todo o espaço, Christaller identificaria na figura geométrica do hexágono semelhanças com a estrutura espacial argumentada. Esta, ao apresentar equivalência entre o lado e o raio da circunferência que o circunscreve, contemplaria a necessidade de equidistância entre o centro e os vértices da figura, algo crucial para o contexto apresentado e proposto.

O modelo seria formado então por um conjunto de áreas de mercado, as quais apresentariam em seus centros os respectivos lugares centrais. Com a consideração do fator hierarquia, chegar-se-ia a uma sobreposição das diferentes áreas de mercado, ocorrendo assim um domínio de um centro de ordem superior sobre determinada quantidade de centros de ordens inferiores (figura 3-1).

O autor apontaria, entretanto, que a formulação abstrata apresentada poderia estar mais próxima à realidade mediante a consideração de alguns cenários. Admitese então que a distribuição e a densidade da população poderiam variar com a existência de determinados elementos topográficos, acidentes geográficos, entre outros. Desta forma, a regularidade do sistema de lugares centrais poderia dar lugar a um conjunto de formas geométricas mais irregulares. Neste cenário, seriam três os princípios capazes de determinar a organização do sistema de lugares centrais: o princípio do mercado, o princípio do tráfego e o princípio da separação administrativa (ABLAS, 1982). 
Enquanto o princípio da área de mercado refletiria a relevância da área de abrangência do bem central na organização, número e localização dos lugares centrais, o princípio do tráfego, por sua vez, moldaria o sistema de acordo com o traçado das linhas de tráfego. Dentro disto, os lugares centrais localizados a beira de uma estrada, por exemplo, tenderiam a apresentar uma área de influência mais estreita, de acordo com a direção da via. Em contrapartida, os lugares mais isolados, distantes das principais rotas ou "cortados" por vias secundárias, tenderiam a produzir áreas de influência de formato mais arredondado. (figura 3-2).

\begin{abstract}
Uma vez que o princípio do mercado conduz a uma estrutura hexagonal regular, do tipo "alveolar", correspondendo a um espaço homogêneo e abstrato, a tomada em consideração das vias de comunicação, numa análise concreta do espaço diferenciado, leva a uma distribuição do tipo linear das aglomerações, cuja área de influência se estende ao longo dos eixos de transporte. (RAMOS e MENDES, 2001)
\end{abstract}

Já o princípio da separação territorial administrativa ou socio-político, surgiria, de acordo com Ablas (1982), a partir da necessidade de separação de comunidades em grupos que possibilitassem a defesa destes em relação à possíveis hostilidades externas, através da aglomeração de centros menores entorno de um núcleo principal. Nesta situação, o modelo ideal de Christaller poderia ser modificado em situações nas quais lugares centrais de mesma ordem assumissem posições tanto de centro como de "satélite", dependendo da unidade política de inserção (figura 3$3)$.

Segundo o mesmo autor, "a ideia principal é organizar o todo, que é praticamente ilimitado, em partes menores de tal forma que cada uma dessas partes possa ser considerada como uma unidade administrativa" (ABLAS, 1982). Além disso, estas deveriam formar distritos virtualmente completos, os quais, dentro do possível, deveriam apresentar população equivalente. No que tange aos seus limites territoriais:

As fronteiras, por sua vez, serão formadas em regiões com densidades demográficas menores e seguirão bastante os obstáculos naturais do relevo, e não poderão partir duas cidades ao meio. Assim, o sistema de lugares centrais definido a partir do princípio sócio-político não terá uma correspondência com o sistema definido a partir dos outros dois princípios. (ABLAS, 1982) 


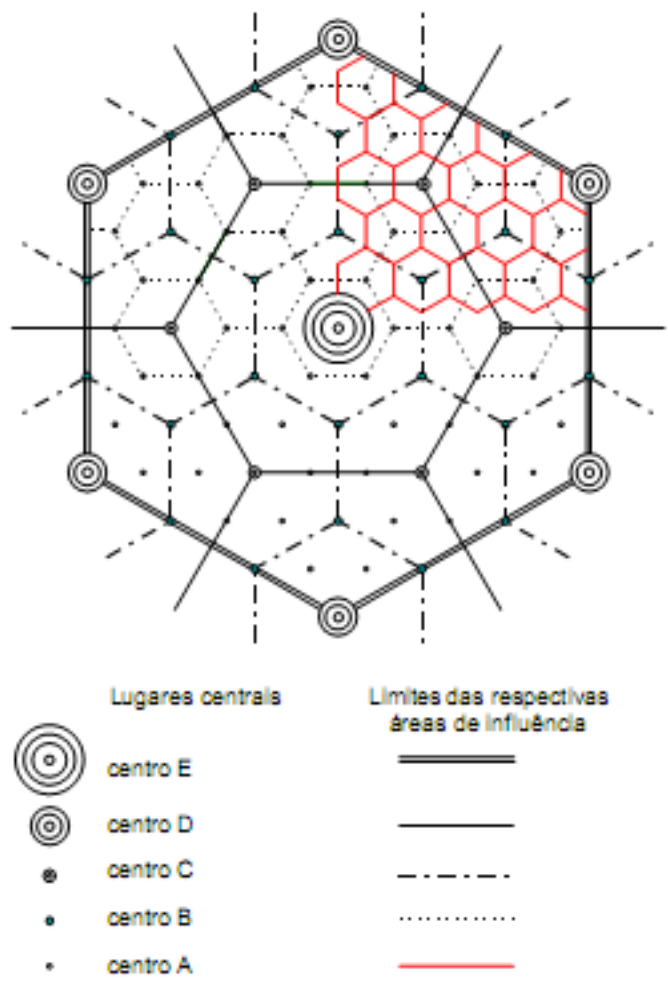

Figura 3-1 - Modelo hexagonal de Christaller. Fonte: Ramos e Mendes (2011)

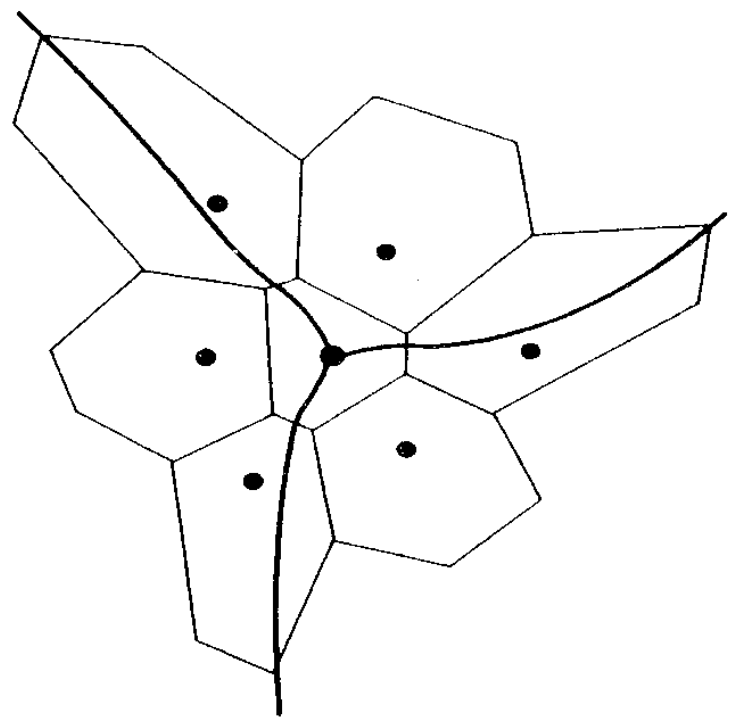

Figura 3-2 - Teoria dos Lugares Centrais de Christaller - Princípio do tráfego. Fonte: Ablas (1982) 


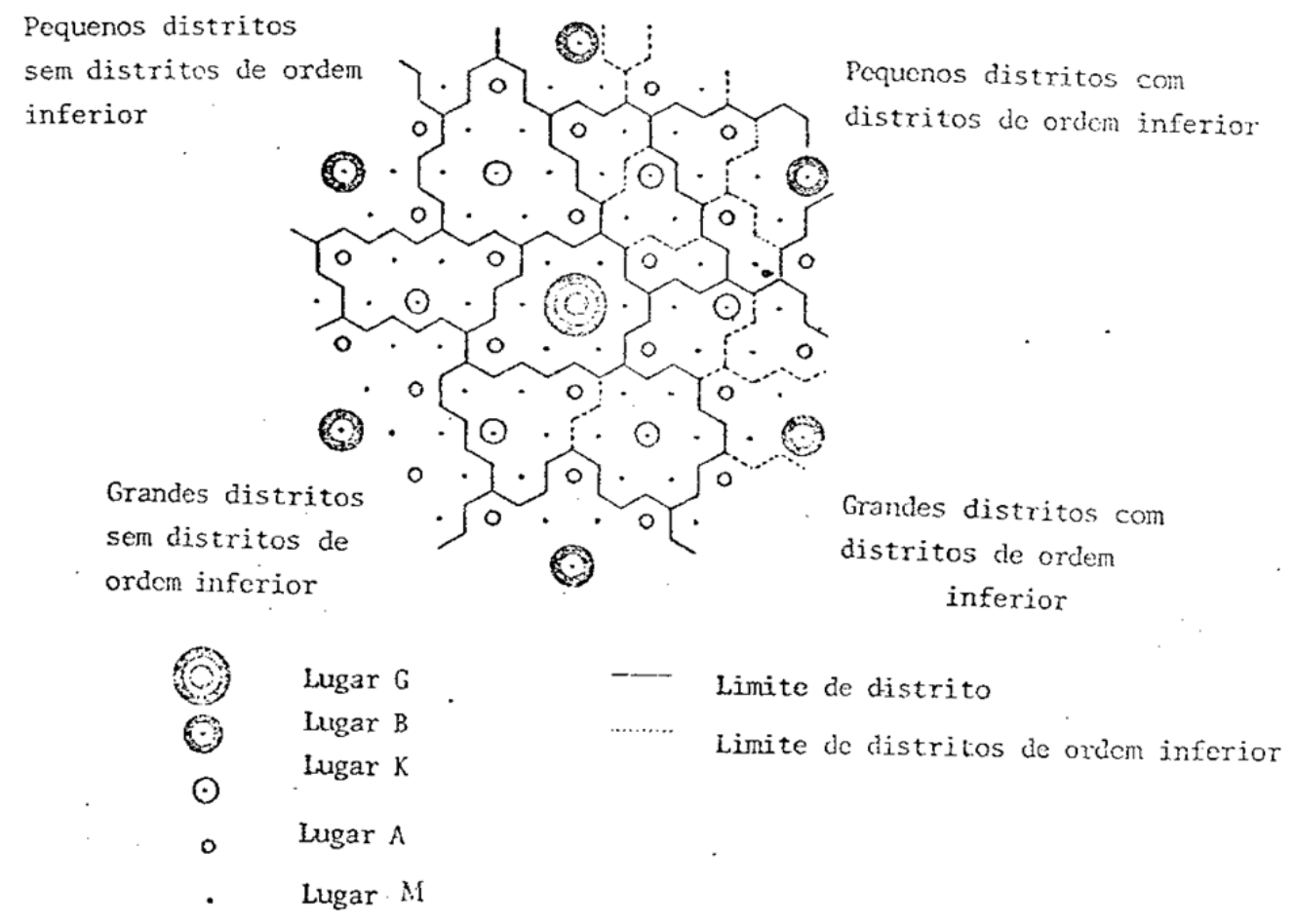

Figura 3-3 - Teoria dos Lugares Centrais de Christaller - Princípio da separação administrativa.

Fonte: Eufrásio (1981)

Dentro do exposto acima, pode-se identificar na teoria christalliana inúmeros pontos de considerável importância e contribuição para a construção do encadeamento lógico pretendido neste capítulo. Primeiramente, retomando nossa indagação acerca da concepção de cidade, a noção apresentada por Christaller de que a mesma poderia ser definida enquanto um lugar central, caracterizado pela concentração de pessoas e atividades econômicas e pela ocorrência de uma região complementar no entorno, além de nos parecer bastante coerente, apresenta possibilidade de analogia com a própria organização político-administrativa do Brasil. O município brasileiro não poderia ser associado a um conjunto territorial formado por uma área complementar e uma sede/cidade específica?

O problema aqui existente, também exposto por Christaller, consiste na diferença entre a malha de áreas de influência reais do conjunto de cidades e a malha oriunda da divisão do território para fins político-administrativos, as quais, segundo o referido autor, não apresentariam coincidência devido a suas origens e 
funcionalidades distintas. A análise espacial christalliana, realizada sob um viés econômico, considera as cidades como competidoras entre si, havendo assim uma hierarquia entre as mesmas dependendo do nível de centralidade que possuem. Cidades menores, ao mesmo tempo em que apresentam suas próprias áreas de influência, também estariam inseridas na área de influência de cidades maiores.

De fato, o município não se constitui enquanto uma divisão econômica do território nacional, mas sim como uma repartição político-administrativa do mesmo. Isto, por si só, invalidaria o uso da Teoria dos Lugares Centrais para os nossos propósitos? Absolutamente não. As diferentes sedes municipais existem sob uma condição de igualdade de um ponto de vista jurídico, político e administrativo, não havendo domínio de umas pelas outras, mesmo dentro de uma situação de perceptível dependência econômica. Sob este ponto de vista não há hierarquia entre elas. Mesmo assim, a teoria christalliana é perfeitamente cabível se consideramos, então, todas as cidades em um mesmo patamar, dotadas dos mesmos serviços centrais primordiais, ou pelo menos, da obrigação de prestação dos mesmos.

Smailes (1947), ao buscar analisar a falta de parâmetros coerentes para a delimitação de áreas de influência urbanas na Inglaterra e, partindo de uma concepção de total interdependência entre a cidade e sua região de entorno formando um todo geograficamente e socialmente inseparável - atenta-se para a importância da diferenciação entre funções primárias (escolas e hospitais, por exemplo), presentes em qualquer centro urbano, e funções mais específicas (centros médicos especializados e universidades, por exemplo), caracterizadas pelo alcance em nível regional e não necessariamente existentes em todas as cidades, como fator de suma importância para a identificação das esferas de influência reais das diferentes cidades.

In selecting indices by which to measure the urban field the essential functions of urban centers must be a governing consideration, so that the indices chosen shall really reflect these functions. Towns act as centers of employment, as collecting and marketing points for the products of the surrounding areas, and as distributing centers for goods from outside these are their primary economic functions. Their more specifically social functions area as centers for the provision of educational, health, recreational and cultural services; and they also act as crystallizing points of regional and district feeling and thought, as well as disseminators of external influence. (SMAILES, 1947) 
Some index features that may be used are common to all fully fledged towns, but others of a more specialized character are possessed only by the higher ranks of urban centre. Thus, secondary schools represent a centralized educational service with which well-nigh every place that can lay claim to urban status in equipped, but universities are found in only a few major centers. The more highly centralized institutions are hall-marks of high urban rank, and as such it is important to examine their range as well as those of the more elementary functions. (SMAILES, 1947)

Included in the minimum equipment in central services indicative of urban status are secondary schools and hospitals. The service areas of these institutions indicate the range of a town's functions as district educational and medical centre respectively. The higher grades of urban centre are also equipped with large general hospitals and special medical services such as deep X-ray facilities, and with additional educational institutions such as technical colleges, art schools, and in a few cases, university colleges. The catchment areas of these institutions will obviously provide measures of the wider regional influence of such centers. (SMAILES, 1947)

Dentro disto, se considerarmos a existência das funções básicas como algo primordial para a própria consolidação da sede municipal como tal e, não levarmos em conta as possíveis diferenças qualitativas, as quais tornariam a análise complexa e relativamente subjetiva, torna-se aceitável a equiparação entre todas as cidades, mesmo que isso possa parecer, pelo menos em princípio, um tanto quanto estranho ou exagerado.

Chega-se assim a nossa concepção funcional do município: uma área de influência político-administrativa de uma determinada cidade, caracterizada pela jurisdição de um governo específico e pela obrigação de prestação de serviços elementares por parte do mesmo. Em outras palavras, tomando de empréstimo um termo e consideração apresentados por Castro (2005), o município consistiria no "espaço atendido" por uma determinada cidade, ou seja, no espaço de alcance ou de influência de sua respectiva função administrativa, caracterizada pelo provimento de serviços às coletividades no interior do território.

Desta forma, acredita-se que o estabelecimento de limites territoriais a um município deve buscar a proximidade, o máximo possível, com a área de influência da sede municipal correspondente. Se a cidade é o local de oferta de serviços públicos como hospitais e escolas, por exemplo, a respectiva linha limítrofe municipal deve incluir, em um mesmo território, todo o conjunto de pessoas que, em momentos de necessidade de algum serviço central, utilizam, ou tendem a utilizar, aqueles ofertados pela mesma. Busca-se, assim, aproximar o município jurídico do 
município de fato, espacialmente real. Além disso, intenta-se diminuir os problemas relacionados à divisão errônea de recursos - assim como apontado no capítulo 1 uma vez que cada município abarcaria a quantidade de pessoas efetivamente "dependentes" dos serviços por ele ofertados. Ganha o Estado, mas também ganha a população, a qual passa a estar juridicamente atrelada ao município no qual realmente a sua vida se efetiva, dentro do qual o próprio exercício da cidadania, entendida, segundo Castro (2003), enquanto um conjunto de direitos e deveres do cidadão em meio à relação indivíduo-comunidade, torna-se mais fácil e concreto. Como bem aponta Cazzolato (2011), "os limites do território estão a serviço das pessoas e da sociedade, e não ao contrário".

Por fim, deve-se ressaltar que a delimitação territorial de municípios não apresenta os mesmos elementos de grande complexidade atrelados as fronteiras estaduais ou nacionais. A inexistência, no âmbito municipal, de dificuldades impostas por diferenças étnicas, linguísticas, culturais, religiosas, etc., acaba por "simplificar" o processo de uma forma geral.

\subsection{TERRITÓRIO, FRONTEIRAS E CIRCULAÇÃO}

Sendo a área de influência o elemento-chave que deve ser buscado, os fatores que a determinam também devem estar claros. Assim, tendo em mente a igualdade proposta entre todas as cidades e, concordando novamente com Christaller, a circulação surge como elemento central de análise. Caracterizada, segundo Smailes (1947), enquanto um movimento de pessoas e produtos, a relação entre o lugar central e sua região complementar não ocorre de forma desassociada aos meios de circulação, pelo contrário, a situação de dependência surge e se desenvolve de forma intimamente correlacionada as vias existentes ou projetadas para tal. Mas aqui não reside uma originalidade ou especificidade da teoria de Christaller. A discussão sobre o papel da circulação para o domínio do território, sob um viés político ou econômico, pode ser encontrada em inúmeros trabalhos clássicos da Geografia. 
De acordo com Silva Junior (2012), o uso da noção de circulação apresenta origens nas descobertas da fisiologia sobre a circulação sanguínea, sendo transposta tanto para Geografia como para as Ciências Sociais em geral a partir dos trabalhos pioneiros de William Harvey, médico londrino responsável pela descrição em detalhe da circulação do sangue, em 1628. Posteriormente, o fluxo circular seria "transformado" em objeto econômico dentro do pensamento dos chamados fisiocratas, desenvolvedores de um sistema geral de relação entre gastos, trabalho, ganho e consumo, dentro do qual haveria uma relação em forma de fluxo de compradores, vendedores, credores e devedores.

O pensamento da Fisiocracia teria influencia direta sobre as formulações de Saint-Simon sobre as redes - base para o melhor controle estatal e uma boa administração - e a circulação do "sangue-dinheiro", elemento essencial para a manutenção do corpo social (SILVA JUNIOR, 2012).

\begin{abstract}
A originalidade de Saint-Simon (Claude-Henri de Rouvroy, Conde de SaintSimon, 1760-1825) - apesar das várias críticas já proferidas a respeito do pensamento do filósofo - foi a consideração da circulação enquanto um elemento responsável pela relação entre os diversos agentes econômicos e sociais esparsos no espaço, a partir da ação estatal para construção de infraestruturas de "comunicações" (e incluem-se nesse caso as infraestruturas de transportes), para fins de controle por parte do próprio Estado e para circulação e acumulação de capital. (SILVA JUNIOR, 2012)
\end{abstract}

A relação circulação-sociedade-Estado também ocorreria na mesma época no interior das análises de Herbert Spencer, pai do "darwinismo social" e propositor de uma sociologia evolucionista. Nas relações entre sociedade e Estado a circulação teria um papel estratégico e de controle por parte do segundo, centro do corpo social e responsável pela implantação de técnicas de circulação direcionadas ao uso da informação e à expansão de sua influência (MATTELART apud SILVA JUNIOR, 2012).

Ainda dentro das considerações de Silva Junior (2012), seria a partir deste quadro de ideias e das consideráveis mudanças nas formas de transporte e telecomunicações entre o fim do século XIX e início do século XX que a circulação seria abordada no interior da Geografia, destacando-se autores clássicos como Friedrich Ratzel, Paul Vidal de La Blache, Camille Vallaux, Jean Brunhes, Jean Gottmann e Maximilien Sorre. 
Ratzel apresentaria, em sua "Geografia Política", uma noção de circulação atrelada ao seu entendimento do Estado enquanto organismo vivo. Nesta, os "processos circulatórios" apresentariam papel primordial na ligação das distintas partes e elementos do corpo estatal (SILVA JUNIOR, 2012).

\begin{abstract}
O ato de circular é expresso por Ratzel como "fenômeno das comunicações, das suas redes e circuitos". Ele analisou a circulação soberana do espaço, sempre em relação à ideia de expansão geográfica, e especialmente política. Para tanto, a movimentação dos corpos em distensão e contração, em progressões e regressões, objetiva o domínio do espaço pelos Estados e outros agentes. (SILVA JUNIOR, 2012)
\end{abstract}

Silva Junior (2012) também destaca, dentro da análise do pensamento ratzeliano, que as vias seriam formadas em disposição semelhante a "grandes artérias", dentro de um sistema em que seriam alimentadas pela circulação local, correspondentes as veias. Além disso, as regiões seriam delimitadas e funcionalizadas a partir da circulação, tais como as "regiões de passagem" e as "regiões entrepostos". Em suma, a circulação seria o principal agente para o desenvolvimento do Estado.

Camille Vallaux, em "El suelo e y El Estado", de 1911, dedica um capítulo inteiro a análise da circulação, entendida sobretudo a partir de seu aspecto político e em detrimento da abordagem econômica - análise das necessidades de produtos e das desigualdades produtivas das regiões do globo - predominante até então. A simples troca de bens materiais nada mais seria que um conjunto de interesses individuais mais ou menos numerosos, mas não capazes, por si só, de construírem ou edificarem vias consideráveis, as quais só poderiam existir mediante a ocorrência de um pensamento coletivo e de uma força social, personificados na figura do Estado. (VALLAUX, 1914).

Un sistema de caminos supone un desenvolvimiento político avanzado, en el cual los medios de comunicación están combinados entre sí, tanto para asegurar en el Estado el libre empleo de sus recursos y de sus fuerzas, como para poner la competencia em relación con las vias generales del comercio. (LA BLACHE apud VALLAUX, 1914) 
Para Vallaux (1914), a relação entre circulação e Estado ocorreria dentro de uma situação de interdependência. Em um primeiro momento, a circulação poderia existir de forma independente ao Estado. Entretanto, mesmo dentro uma nítida motivação econômica, ainda seriam preponderantes os fatores relacionados à segurança e as obras de manutenção e criação de novas vias, estritamente ligadas a ação estatal. Ao mesmo tempo, o Estado seria "dependente" de seus caminhos, uma vez que a partir destes concretizaria a soberania sobre o seu território. Logo, o aspecto político ocorreria de forma intrínseca as vias de circulação, correspondentes a verdadeiras linhas estratégicas de poder.

Como forma de argumentação de seu ponto de vista, Vallaux defende que, caso o fator econômico fosse único e preponderante na definição das vias de circulação, seria possível identificar correspondências entre os traçados e as facilidades do terreno nos antigos caminhos e rotas. Dentro disto, seria esperado que as vias atravessassem áreas mais planas, de pouca declividade e ondulação, além de sempre intentar a conexão de centros econômicos pré-existentes. Apesar de existirem casos dentro destas condições, a maioria estaria em desacordo com as mesmas, o que evidenciaria a importância política - muitas vezes oculta - destes caminhos.

\begin{abstract}
Un sistema de caminos que se modelara sobre el suelo y se adaptase com precisión seria ante todo un sistema de rutas del orden económico; estaría destinado, en primer término, á facilitar el cambio y el paso de los productos. No es este el caráter de las antiguas redes de circulación general: no están hechas para la comodidad y la facilidad del transporte de los productos y de los hombres; brilla aqui con toda evidencia su carácter político. (VALLAUX, 1914)
\end{abstract}

Além disso, o caminho também apresentaria um caráter militar. Em Roma, por exemplo, a rede de vias militares teria agido como um "cimento" de aglutinação de todo o império. Em adição a isto, a construção de caminhos seria elemento coincidente na ação de todos os conquistadores de destaque da história. A própria formação dos grandes territórios imperiais ocasionaria, devido a crescente heterogeneidade, a necessidade de correção das tendências centrífugas existentes mediante o estabelecimento de vias de acesso rápido e fácil. A circulação teria ação uniformizadora do espaço (VALLAUX, 1914). 
La agrupación y la multiplicación de las vías, las interpenetraciones continuas, el crecimiento de la población y la explotación del subsuelo, las luchas de lengua y de cultura acentúan, en los países que están desde el mar del Norte al Rhin medio, las diferenciaciones antiguas; mientras que numerosas zonas pequeñas de diversidad y hasta de contraste pierden todo valor desde el punto de vista político; la circulacíon las uniforma. Así, el desenvolvimiento de la circulación simplifica la geografía del Estado y trastorna los valores relativos de las zonas de diferenciación. (VALLAUX, 1914)

Em sua "Geografia Humana", de 1910, Jean Brunhes, ao tentar analisar os fatores determinantes para a localização geográfica das instalações humanas, já apontava para a relevância dos caminhos e estradas. Segundo o mesmo, a ocorrência de casas "orientadas" para o sol, característica de situações iniciais de certo isolamento, seria substituída com o surgimento de aglomerações humanas e com a formação das cidades, as quais passariam a apresentar casas com fachadas voltadas primordialmente para as vias de circulação, orientadas de acordo com o traçado das mesmas.

Pero si, por ejemplo, las casas aisladas de la meseta suiza pueden volverse y se vuelven casi todas hacia el lado del sol, el problema no es el mismo cuando las casas están aglomeradas; la calle tiene a menudo, en este caso, un papel director, y la fachada principal no se vuelve hacia el sol, sino hacia la vía de circulación, carretera o calle. (BRUNHES, 1962)

Dentro disso, Brunhes aponta para uma estreita ligação entre as cidades e as vias de circulação. No interior de uma relação de mão dupla, cidade e estrada se complementam - ao mesmo tempo em que o crescimento da cidade contribui para um maior adensamento de sua rede de transporte, o estabelecimento de estradas também é determinante para o surgimento e crescimento de uma aglomeração urbana. Em suas palavras "As necessidades essenciais dos habitantes exigem, para sua satisfação, uma densa rede de vias de comunicação." (BRUNHES, 1962).

La carretera va hacia el centro urbano y de él depende; pero el centro edificado depende también de la carretera. La ciudad crea la carretera; a sua vez, la carretera crea la ciudad, o la vuelve a crear, es decir, cambia su situación o la desfigura. (BRUNHES, 1962) 
A partir de uma análise mais direcionada ao caráter político-militar das vias, Brunhes também destaca o papel preponderante das estradas para 0 estabelecimento territorial de grandes impérios da história - China, Roma, Incas e Napoleônico - e a formação de "estrelas viárias" ao redor de capitais econômicas e políticas. A conquista e o domínio de novas áreas apresentaria considerável dependência da rede de estradas implantadas ou em implantação.

Siempre que un poder pretende implantarse en una nueva región, traza y abre una carretera. Este ha sido el sentido del transcaspiano, del transiberiano y de todos los trans continentales, tales como la vía de expansión británica del Cabo al Cairo. (BRUNHES, 1962)

Estradas e caminhos apresentariam, então, papel relevante na orientação espacial de povos e cidades. A circulação, além de transformar a superfície de forma material, também acarretaria modificações quantitativas e qualitativas na própria humanidade. Dentro disto, o espírito de dominação do homem - necessidade histórica de conquistar e dominar o espaço - seria responsável pelo progresso e desenvolvimento das vias de circulação, consolidadas enquanto elementos fundamentais para a efetivação deste processo. (BRUNHES, 1962).

O aspecto político da circulação seria posteriormente tratado, segundo Silva Junior (2012), por Sorre (1948) e Gottmann (1952). Para o primeiro, além de servirem como elemento de "expansão do ecúmeno", as vias de circulação também estariam dotadas de uma função política e civilizatória, circunscritas em funções geopolíticas e estratégicas. Para o segundo, a circulação influenciaria diretamente na posição geográfica e nas consequências políticas de um território, caracterizando-se como um elemento determinante em meio à um possível "determinismo das relações espaciais" (SILVA JUNIOR, 2012).

Além destes, pode-se destacar a contribuição de A.E. Moodie em "Geografia e Política", de 1965. Para este autor, os meios de circulação e comunicação, abrangendo a movimentação de pessoas, mercadorias e ideias, aparecem, nos tempos atuais, como elementos de extrema importância para a atividade humana em qualquer nível de análise - do municipal ao internacional. Para a Geografia Política, seriam de notável relevância, caracterizando-se como canais de desenvolvimento e 
de organização estatal. A própria civilização poderia ser entendida, em grande parte, como um produto da circulação (MOODIE, 1965).

\begin{abstract}
Nesse amplíssimo sentido, as comunicações modernas facilitam o movimento das utilidades, pessoas e ideias, dentro e entre os Estados. Exercem influência unificadora que varia na proporção direta da densidade da capacidade transportadora de vários sistemas. São poucos os obstáculos físicos que resta vencer, porém, paradoxalmente, são ainda comuns as barreiras artificiais que constituem o maior entrave ao livre curso, sem o qual a circulação não pode exercer sua máxima influência benéfica. Eis por que o estudo das comunicações constitui importante aspecto da Geografia Política. O seu estabelecimento e desenvolvimento estão intimamente relacionados às políticas interna e externa dos Estados. Todos os fatores políticos, estratégicos, econômicos e culturais estão aí compreendidos, e a crescente complexidade das relações nacionais e internacionais exige o bom funcionamento das comunicações de todos os tipos. (MOODIE, 1965)
\end{abstract}

Segundo o referido autor, esta importância já poderia ser observada nos primórdios da organização do homem em comunidades e ao longo de sua própria história. Em um primeiro momento, as melhores condições de mobilidade teriam influenciado decisivamente na preponderância de certos grupos sobre outros. Enquanto egípcios, mesopotâmios e chineses utilizaram os rios como vias de comunicação de utilização comercial e militar, as cidades-Estado gregas e Roma estabeleceram relevante domínio sobre o transporte marítimo. Os mesmos romanos integrariam as conquistas territoriais do império a partir do estabelecimento de um sistema de estradas. O posterior domínio do feudalismo só seria possível com a "extinção" da mobilidade organizada ao longo de rotas bem definidas - a excessiva fragmentação feudal ocorreria mediante a falta de contato entre as distintas comunidades, situação em que a lei/ordem apresentava possibilidade de manutenção restrita apenas ao raio de abrangência dos poderes locais. Esta situação também seria suplantada novamente com a "participação" dos meios de circulação. Neste sentido, a era de "obscuridade" deixaria de existir a partir de uma revolução nos transportes, a partir das Grandes Navegações. As subsequentes expansões econômicas e territoriais das potências europeias explicitariam, por sua vez, a necessidade real de estabelecimento de uma rede de vias de comunicação terrestres em suas colônias.

Circulação e Estado apresentariam uma relação estreita e necessária, na qual o estabelecimento, manutenção e aperfeiçoamento da primeira torna-se essencial para o desenvolvimento do segundo, dentro de possíveis conotações econômicas, 
políticas ou militares. A própria existência do Estado como unidade autônoma estaria subordinada à suas condições de circulação - materiais e de ideias (MOODIE, 1965).

\begin{abstract}
Ademais, não pode haver sistema de Governo eficiente sem meios de comunicação adequados, qualquer que possa ser o regime político em particular. A centralização do poder político, que em grande proporção é característica de todos os Estados, jamais poderia ter sido conseguida sem circulação organizada. É difícil, aqui, separar a causa do efeito. As tentativas para concentrar o poder político na sede do Governo precederam a construção de estradas e vias férreas, mas uma vez aceita esta política interna e logo que estruturação de comunicações excedeu a fase inicial das exigências locais e regionais, foi impossível evitar que, quando as linhas de movimento atingissem padrão "nacional", reforçassem a influência diretiva tanto do Estado como das sedes provinciais. Tendo em vista a função unificadora das comunicações, as autoridades governamentais criaram, então, planos para a extensão e aprimoramento das comunicações com o objetivo de centralizar, ainda mais, toda a ação das atividades da circulação, de modo que os pontos focais das rotas importantes receberam novo acesso de atividade. (MOODIE, 1965)
\end{abstract}

Dentre as análises mais recentes da temática, Raffestin (1993) aponta para a presença de elementos de circulação e comunicação - duas faces da mobilidade em todo tipo de ação estratégica desencadeada com o propósito de dominação da superfície e de gestão e controle das distâncias. Apesar de se atentar para a distinção entre circulação (transferência de seres e bens) e comunicação (transferência de informação), o autor destaca que há ocorrência concomitante das mesmas. Toda informação comunicada seria, ao mesmo tempo, um "bem" que circula (RAFFESTIN, 1993).

A mobilidade, ao ser incorporada como um elemento crucial para qualquer tipo de estratégia, acarretaria uma função circulação-comunicação, tornando-se uma função de poder. A circulação seria responsável pela produção de uma determinada ordem, atrelada ao poder correspondente, caracterizando assim, as redes enquanto "instrumentos" do mesmo. (RAFFESTIN, 1993).

A rede aparece, desde então, como fios seguros de uma rede flexível que pode se moldar conforme as situações concretas e, por isso mesmo, se deformar para melhor reter. A rede é proteiforme, móvel e inacabada, e é dessa falta de acabamento que ela tira sua força no espaço e no tempo: se adapta às variações do espaço e às mudanças que advêm no tempo. $A$ rede faz e desfaz as prisões do espaço, tornado território: tanto libera como aprisiona. É o porquê de ela ser o "instrumento" por excelência do poder. (RAFFESTIN, 1993) 
Circulação e comunicação procedem de estratégias e estão a serviço delas. Redes de circulação e comunicação contribuem para modelar o quadro espaço-temporal que é todo território. Essas redes são inseparáveis dos modos de produção dos quais asseguram a mobilidade. Como são sistemas sêmicos materiais, surgem de uma "leitura" ideológica em vários níveis: enquanto são traçadas, enquanto são construídas e enquanto são utilizadas ou, se preferirmos, "consumidas". Desenho, construção e utilização de uma rede dependem dos meios à disposição (energia e informação), dos códigos técnicos, sociopolíticos e socioeconômicos, assim como dos objetivos dos atores. (RAFFESTIN, 1993)

De acordo com o autor, o caráter móvel das redes estaria ligado diretamente com os atores que geram e controlam os seus pontos ou a posição relativa destes em relação aos fluxos oriundos da circulação e comunicação presentes nas mesmas. Além disso, a multiplicação das redes de comunicação em grandes países revelaria uma concepção de poder de fixação mais "espacial" do que "temporal", dentro da qual seria intentado o controle total do território como ação necessária para a mobilização de pessoas e recursos, a fim de se preservar os "trunfos nas áreas mais extensas possíveis". A própria tomada do poder dependeria de ações de apropriação das redes de circulação e comunicação.

Quem procura tomar o poder se apropria pouco a pouco das redes de circulação e de comunicação: controle dos eixos rodoviários e ferroviários, controle das redes de alimentação de energia, controle das centrais telefônicas, das estações de rádio e de televisão. Controlar as redes é controlar os homens e é impor-lhes uma nova ordem que substituirá a antiga. (RAFFESTIN, 1993)

Dentro de um enfoque menos teórico e mais "prático", o trabalho desenvolvido por Pierre Monbeig em "Pioneiros e Fazendeiros de São Paulo", de 1984, pode ser citado enquanto valioso estudo de constatação da relevância dos meios de circulação para a ocupação, domínio e divisão territorial. Ao analisar o "avanço humano" sobre as terras do oeste de São Paulo e do norte do Paraná, Monbeig apresenta uma situação em que a via, seja ela ferrovia, rodovia ou um simples caminho rural, influenciou de forma decisiva no surgimento de aglomerados urbanos, na divisão político-administrativa mediante a criação de municípios e no cenário fundiário, através da fragmentação e multiplicação de loteamentos e imóveis rurais.

Segundo Monbeig, o panorama agrário e produtivo da região seria alterado com o avanço ferroviário e rodoviário. Em princípio, a questão do isolamento - ou a 
recusa ao mesmo - surge como elemento crucial nas relações sociais e econômicas locais. Terras de características e áreas semelhantes passavam a apresentar valores totalmente distintos de acordo com sua posição em relação às estações e terminais. Além disso, a própria ocupação do território estaria atrelada as novas artérias viárias. O surgimento de inúmeros loteamentos rurais ocorreria sob duas perspectivas fundamentais: a iminência da chegada dos trilhos/estradas e o conhecimento sobre os seus traçados.

\begin{abstract}
Em uma região situada além do terminal rodoviário, a venda das terras está em função da rede rodoviária e dos boatos sobre o eventual prolongamento dos trilhos. Quando estes atingiram Mirassol, em 1920, acreditou-se que os trabalhos seriam rapidamente reencetados, para a construção da linha sobre o espigão entre os rios Tietê e São José dos Dourados. Foi neste momento que os fazendeiros começaram a estender plantações na zona de Monte Aprazível, General Salgado e Magda. Na realidade, o governo do Estado só retornou a construção da estrada de ferro em 1935 e adotou um traçado diferente, colocando os trilhos entre São José dos Dourados e o rio Turvo, na direção de Porto Getúlio Vargas. Imediatamente multiplicaram-se os loteamentos além de Tanabi, em Cosmorama, em Votuporanga (fundada em 1937) e, em seguida, em Fernandópolis, Estrela do Oeste e Vila Jales. Foi principalmente quando os trens entraram em serviço até Votuporanga (1944) que se intensificou a publicidade e aumentou a venda de terras neste resto de sertão. A iminência da chegada dos trilhos e o conhecimento de seu traçado foram aqui os elementos decisivos. (MONBEIG, 1984)
\end{abstract}

A própria disputa imobiliária entre diversos loteadores apresentava a questão da comunicação como elemento chave. Ao mesmo tempo em que se intencionava lotear o mais próximo dos grandes eixos viários, elaborava-se projetos internos de caminhos e vias em meio às crescentes demandas geradas pelo aumento da utilização do modal rodoviário (figura 3.1-1). O acesso tornava-se, então, fator de deveras importância para qualquer tipo de empreendimento. Recusava-se, de fato, o isolamento. (MONBEIG, 1984).

Em outubro de 1946, a concorrência entre os loteadores era intensa e todos fundamentavam sua propaganda nas facilidades de comunicação. As grandes artérias fixavam a posição das pequenas propriedades e a notícia de que uma linha iria ser prolongada desencadeava uma espécie de epidemias de loteamento. De outro lado, cada empresa colonizadora era levada a traçar e a construir uma rede de estradas e de caminhos no interior de seus domínios. (MONBEIG, 1984)

Nas colônias abertas da Alta Sorocabana, entre 1920 e 1925, deixava-se aos pioneiros o encargo de transformar em caminhos as trilhas abertas apressadamente na floresta pelos agrimensores. Mas o que, a rigor, era possível em loteamentos de dimensões restritas numa época em que o caminhão apenas começava a circular, não é concebível em um loteamento 
de grandes dimensões, quando o tráfego rodoviário entrou nos costumes. É essa a razão porque os principais loteadores constroem uma rede de circulação interna, precedendo a colocação dos lotes à venda. (MONBEIG, 1984)

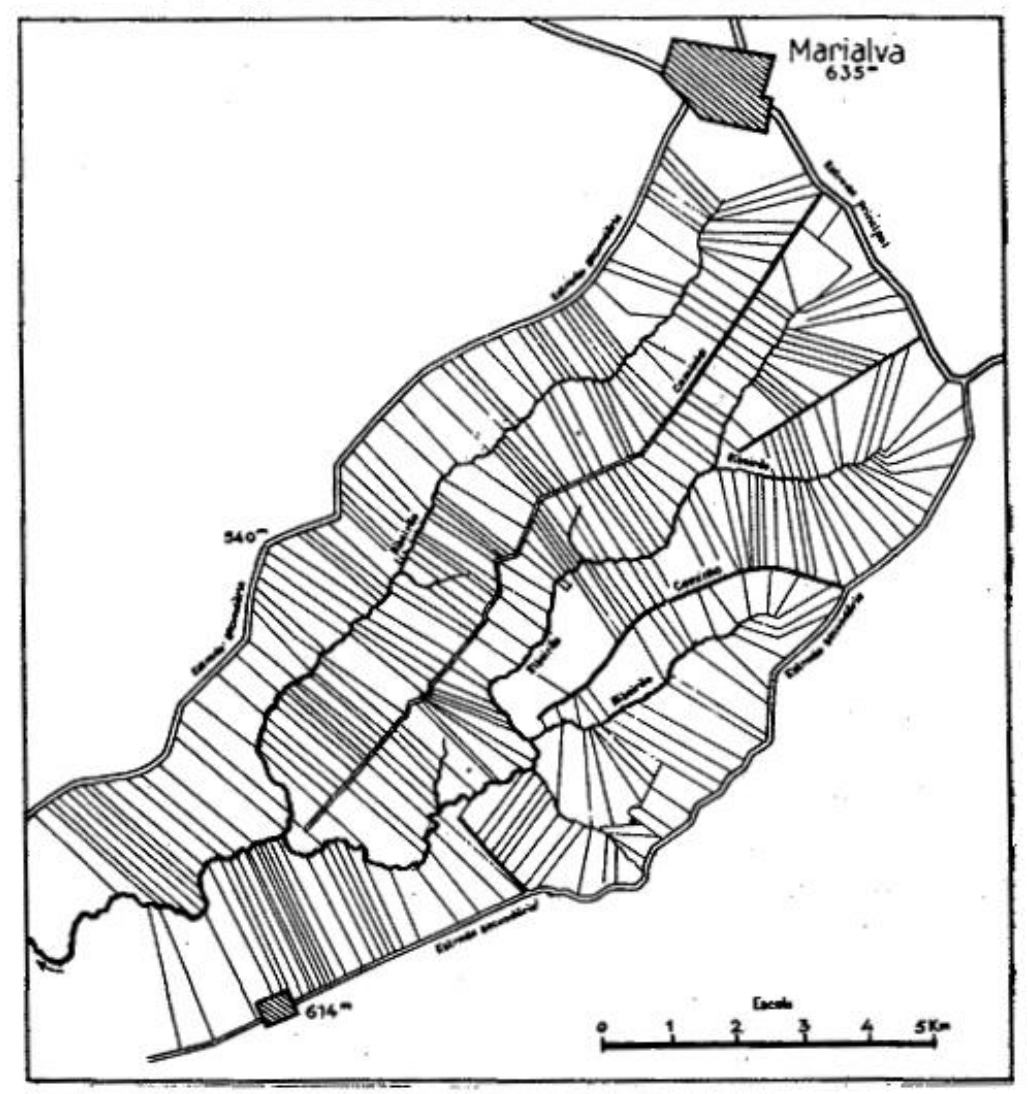

Figura 3.1-1 - Planta de loteamento em Marialva/PR - Disposição dos lotes de acordo com o acesso à água e ao sistema viário interno e externo. Fonte: Monbeig (1984)

No que tange as divisões territoriais em âmbito político-administrativo, o papel das vias de comunicação também seria relevante. Para Monbeig, os trilhos e as estradas de rodagem seriam "agentes" criadores de sítios favoráveis às fundações urbanas. Neste sentido, inúmeros seriam os patrimônios, embriões das futuras cidades e, consequentemente, dos futuros municípios, surgidos a partir de estações ferroviárias, por exemplo.

Por fim, se centrarmos nosso foco de análise não mais no território como um todo, mas especificamente nas suas bordas, em seus limites, a ocorrência da circulação enquanto fator de extrema relevância também pode - e deve - ser identificada. Backheuser (1952), ao analisar a evolução da noção de fronteira apresentando, para isso, uma sistematização histórica em quatro períodos distintos: vazios de ecúmeno; largas zonas inocupadas; faixas estreitas e fronteira linear - 
demonstra como o homem da pré-história e da antiguidade, devido à insuficiência de recursos materiais e intelectuais, acabou sendo limitado espacialmente por obstáculos naturais, caracterizados por áreas de climas extremos e/ou de difícil acesso. Segundo o mesmo, este primeiro tipo de "feição de fronteira" seria composto por elementos como o mar, montanhas escarpadas, florestas espessas e tropicais, desertos, calotas polares, geleiras de altitude e pântanos. Dentro disto, a inexistência de limites políticos instituídos seria "compensada" pela ocorrência do que Ratzel havia denominado enquanto "vazios de ecúmeno", ou seja, áreas no interior da área ecumênica global (área considerada como habitável) resistentes à penetração e habitação humana, no momento inabitadas (BACKHEUSER, 1948).

\begin{abstract}
O Império Romano dilatou-se até aonde deparou esses formidandos óbices. Ao Norte ficou separado dos povos germânicos pelos pântanos extensíssimos das "marcas" da planície Além-Reno; ainda ao Norte, mas em latitude mais baixa, pelas densas florestas e rudes montanhas que dos Alpes, pela Floresta Negra, iam aos Carpatos; a Leste, por esses montes e pelo Cáucaso, ambos de penoso transpor; ainda a Leste, pelo deserto, aquele medonho deserto de areias e pedegrais, do Irã e da Arábia Saudita; pelo Sul "cerrava-o" o Saara, agressivo; a Oeste, o Atlântico misterioso, de cenho carregado, resistente ao navegador desprovido de bússola, só devassado muitos séculos depois, já no Renascimento. Eis a moldura para a época, intransponível, a que se tiveram de restringir as ambições imperialistas de Roma: "vazios de ecúmeno. (BACKHEUSER, 1948)
\end{abstract}

O subsequente desenvolvimento técnico da civilização européia seria responsável, por sua vez, pela superação destas "fronteiras primitivas". Como exemplifica Curzon (1907), enquanto o mar deixava de representar uma barreira para se tornar uma forma de conexão entre várias partes do planeta, mediante o desenvolvimento da navegação, os desertos, tão ou mais inicialmente instransponíveis, ao serem cortados inicialmente por ferrovias, também passavam a "sucumbir" gradativamente ao avanço do homem.

Este contexto de relação entre fronteira e movimento também apareceria na concepção ratzeliana da mesma, a qual seria "constituída pelos inumeráveis pontos sobre os quais um movimento orgânico é obrigado a parar" (Ratzel apud Martin, 1992). Deve-se destacar que, assim como aponta Martin (1992), a fronteira de Ratzel não consistiria em uma situação estacionária eterna, pelo contrário, representaria um momento de estagnação causado pela falta de condições vitais necessárias a sua continuação ou pela resistência de um movimento em sentido 
oposto. Havendo favorecimento das condições vitais ou o enfraquecimento do movimento oposto, a fronteira tenderia a avançar, porém, em situações de perda das condições vitais ou de aumento da força oposta, a mesma tenderia a recuar. Algo totalmente de acordo com o próprio entendimento ratzeliano do Estado enquanto um organismo vivo - e daí a fronteira como a sua epiderme.

O clássico trabalho de Jones (1945), ao relacionar os limites territoriais a diversos elementos físicos, econômicos, históricos e culturais, aponta, mesmo que de uma forma incipiente e precavida, a circulação como um possível parâmetro a ser considerado para o processo de delimitação do território. Neste caso, deveriam ser identificados, como elementos limítrofes, os locais caracterizados por um fluxo ou movimento de menor magnitude, de ocorrência mínima.

\begin{abstract}
...the world may be divided, for the analysis or synthesis of information, into regions of homogeneity or into regions of organization. Regions of homogeneity may be characterized by uniformity of climate, vegetation, landuse, language, or other factor. Regions of organization may be unified by drainage, transportation, trade, government, or other factor. One of the most significant of organizing factors is "circulation," the movement of persons and things, including water supply and electrical power and communication. "Circulation regions" might be delimited by determining the places of minimum movement. How successfully such zones of minimum circulation could be employed in boundary- making is open to debate or, better, to experimentation. (JONES, 1945)
\end{abstract}

Heretofore, treaties usually have delimited boundaries that supposedly were final or have left only moderate leeway for adjustments in demarcation. If strong international organization could make possible experimentation with boundaries, the factor of circulation could well be the basis for some of the approximations. (JONES, 1945)

De forma convergente a Jones (1945), Cazzolato (2011), partindo de uma constatação artificial do território - uma vez que o mesmo surge como criação humana - também relaciona as linhas limítrofes ao movimento e a necessidade de correspondência destas com os pontos de rarefação da circulação. Segundo o mesmo, o processo de estabelecimento de contornos territoriais, embora não possa ocorrer sem a cisão de algum tipo de fluxo, ao priorizar as áreas de menor intensidade, contribui positivamente para a manutenção de nódulos e fluxos de maior grandeza, elementos de extrema relevância para a coesão territorial. 


\subsection{LEI DO MÍNIMO ESFORÇO, EFICIÊNCIA ESPACIAL E O FATOR TEMPO}

Se o município corresponde, dentro do nosso entendimento, à área de influência de uma cidade e, se esta área apresenta a circulação como um parâmetro-chave de definição, de que forma poderíamos superar este estágio teórico em busca de uma aplicação prática? Como transpor todo o encadeamento lógico apresentado para um efetivo processo de delimitação territorial?

De acordo com Haggett (1976), devido à complexidade da realidade, torna-se aceitável - e até mesmo necessária - a utilização de modelos como forma de verificação e constatação de preceitos teóricos mediante a construção de uma imagem simplificada e racional da mesma. Segundo o mesmo, embora o termo "modelo" possa ser empregado de três formas distintas, enquanto representação (substantivo), ideal (adjetivo) ou demonstração (verbo), é possível a incorporação de cada uma delas dentro de uma definição única, caracterizada pela "representacíon idelizada de la realidade a fin de poner de relieve alguns de sus propriedades" (ACKOFF et al apud HAGGETT, 1976).

Partindo deste entendimento, buscar-se-á responder as questões levantadas mediante a consideração de um modelo específico. Para tal, faz-se necessário, em um primeiro momento, a apresentação dos elementos da realidade simplificada considerada, no caso, da situação hipotética inicial: um espaço geometricamente regular (quadrado de $10 \mathrm{~km}$ de lado), caracterizado pela existência de 4 cidades ( $A$, $B, C$ e D), regularmente espaçadas, e de 1 núcleo rural (R). As cidades $A, B$ e $D$ apresentam população de 20.000 habitantes, a cidade $C$ de 17.000 habitantes e o núcleo rural de 3.000 habitantes (figura 3.2-1). 


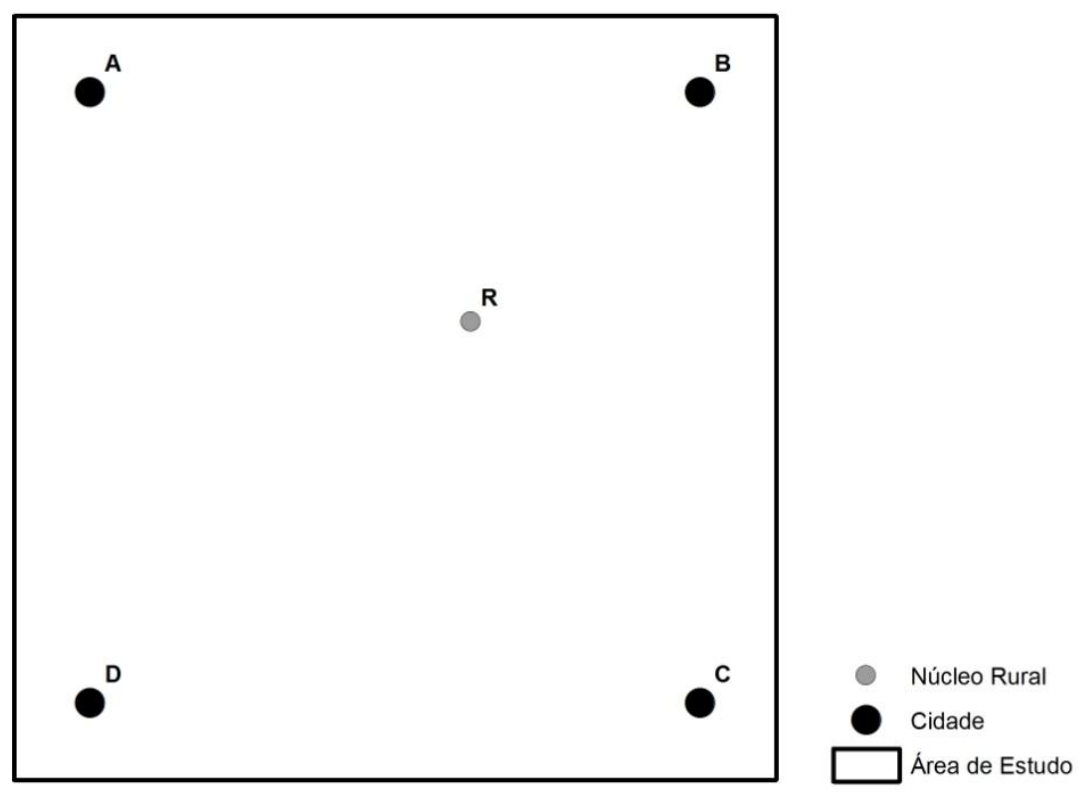

Figura 3.2-1 - Modelo - Situação Hipotética Inicial. Fonte: Elaborado pelo autor

Existindo a necessidade de delimitação de 4 municípios (1 para cada cidade/sede municipal), de que forma deverá ser repartido o espaço? Dentro de qual território municipal o núcleo rural deverá estar alocado?

Para uma primeira proposta poderíamos nos basear primordialmente nas orientações legais tradicionalmente existentes no país, conforme apresentadas no capítulo 2. Aqui, levando em consideração a simples exigência de adoção de limites calcados em acidentes naturais ou em linhas artificiais entre pontos identificáveis, existente, desde 1938, em praticamente todas as leis federais e estaduais ligadas à criação e delimitação de municípios, torna-se imprescindível a consideração de mais uma camada de informação. Neste caso, além da situação hipotética já apresentada, adicionar-se-á a rede hidrográfica, também simplificada e idealizada, para a área de estudo (figura 3.2-2). 


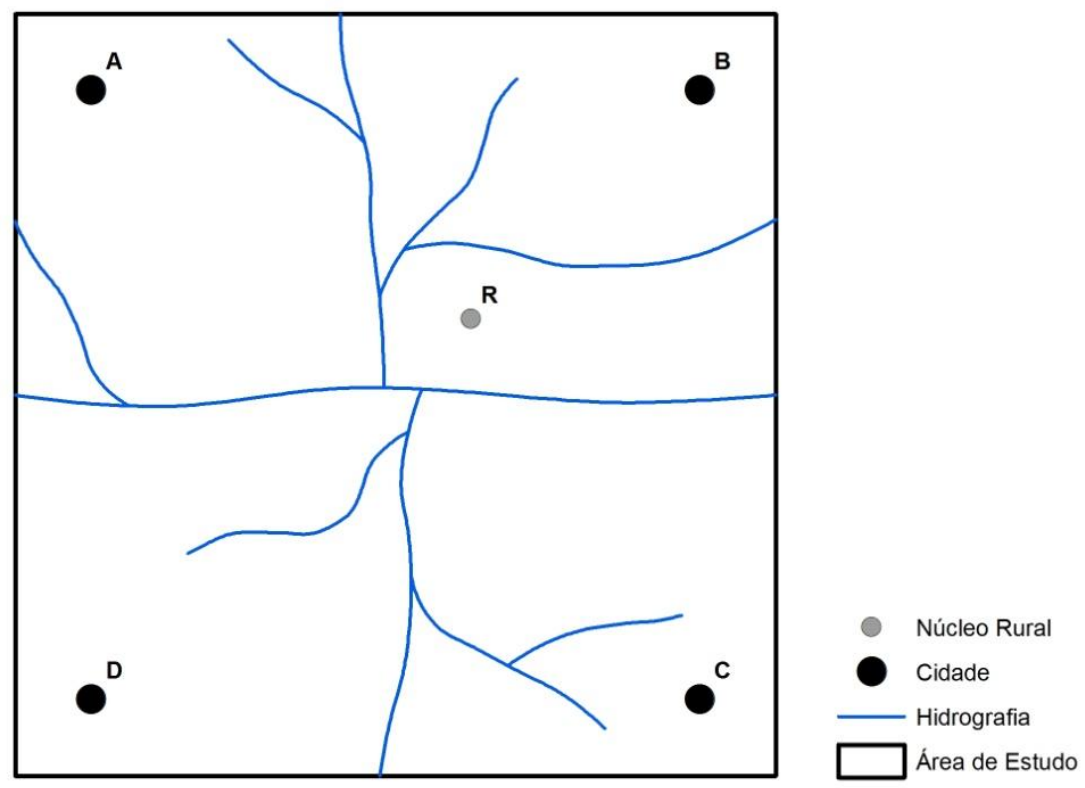

Figura 3.2-2 - Modelo - Rede Hidrográfica. Fonte: Elaborado pelo autor

Neste cenário, devido à configuração proposital da rede hidrográfica, os possíveis elementos físicos de base para os limites territoriais surgem com relevância clareza: o curso de água principal e seus dois principais tributários (figura 3.2-3). Têm-se então uma situação aparentemente próxima ao ideal, caracterizada por territórios com valores de área próximos $\left(23,35 \mathrm{~km}^{2}\right.$ para o município A, 26,99 $\mathrm{km}^{2}$ para o município $\mathrm{B}, 24,33 \mathrm{~km}^{2}$ para o município $C$ e $25,33 \mathrm{~km}^{2}$ para o município D) e de formas regulares, com altos índices de circularidade (0,804 para o município A, 0,781 para o município $B, 0,761$ para o município $C$ e 0,77 para o município $D)^{16}$. Caso o exemplo proposto consistisse em uma situação real, esta seria potencialmente a opção mais esperada dentro do atual estágio técnico e legal vigente no país.

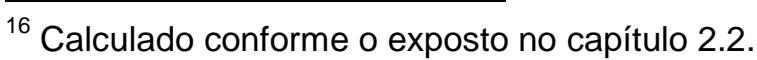




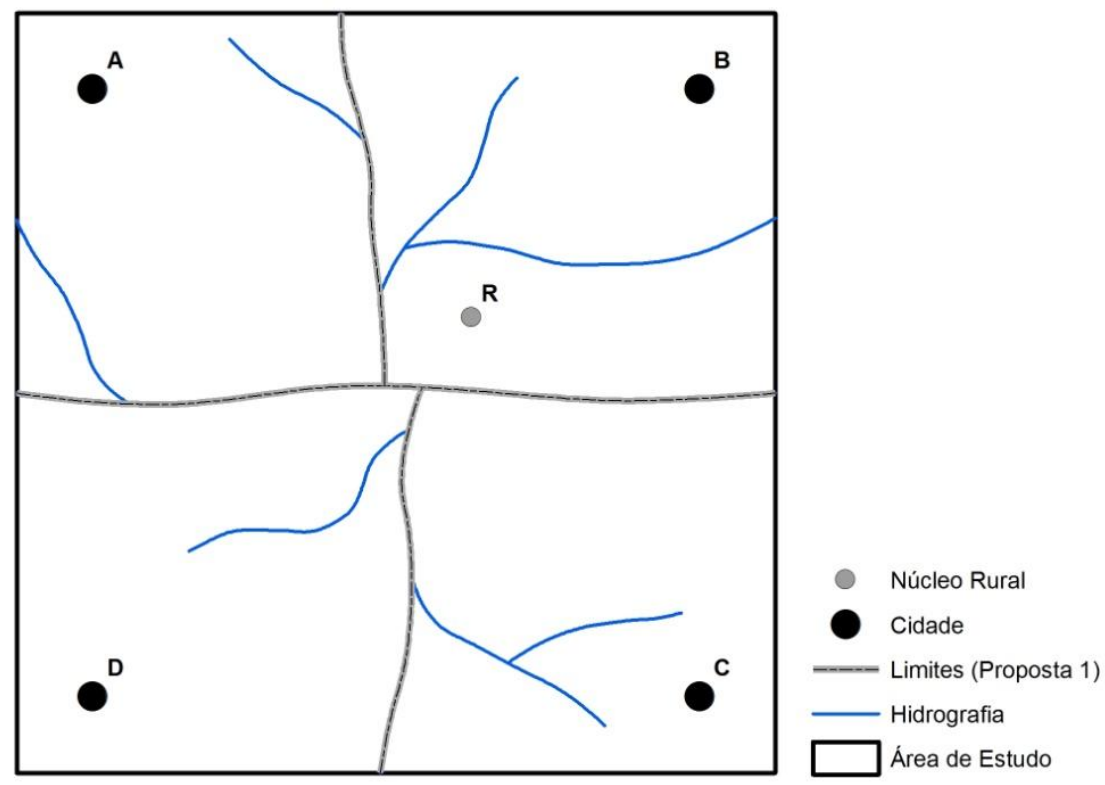

Figura 3.2-3 - Modelo - Limites (Proposta 1). Fonte: Elaborado pelo autor

Se levarmos em conta os dados populacionais atribuídos, um outro tipo de delimitação poderia ser adotado. Partindo de um princípio de maior necessidade de equilíbrio entre os municípios, a consideração da possibilidade de criação de territórios municipais de igual número de habitantes pode surgir como outro parâmetro a ser admitido. Aqui, embora se mantenha o princípio de adoção de "limites naturais", ocorre uma espécie de distorção da situação original, na qual a escolha de um novo curso de água, afluente de um dos tributários do curso de água principal, apresenta-se como a opção mais lógica para a inserção do núcleo rural $R$ no município $C$, resultando em 4 territórios de população de 20.000 habitantes ${ }^{17}$, (figura 3.2-4). Enquanto o panorama das áreas acaba sendo prejudicado (para a igualdade em número de habitantes, um município acaba ficando com um território bem maior do que os demais), o das áreas e formas continua a apresentar números relativamente bons: área de $23,35 \mathrm{~km}^{2}$ para o município $A, 17,27 \mathrm{~km}^{2}$ para o município $B, 34,05 \mathrm{~km}^{2}$ para o município $C$ e $25,33 \mathrm{~km}^{2}$ para o município $D$, além de índices de circularidade de 0,804, 0,675, 0,678 e 0,77 respectivamente.

\footnotetext{
${ }^{17}$ Desconsiderando possíveis focos esparsos e individuais de povoamento existentes além de $A, B, C, D$ e R.
} 


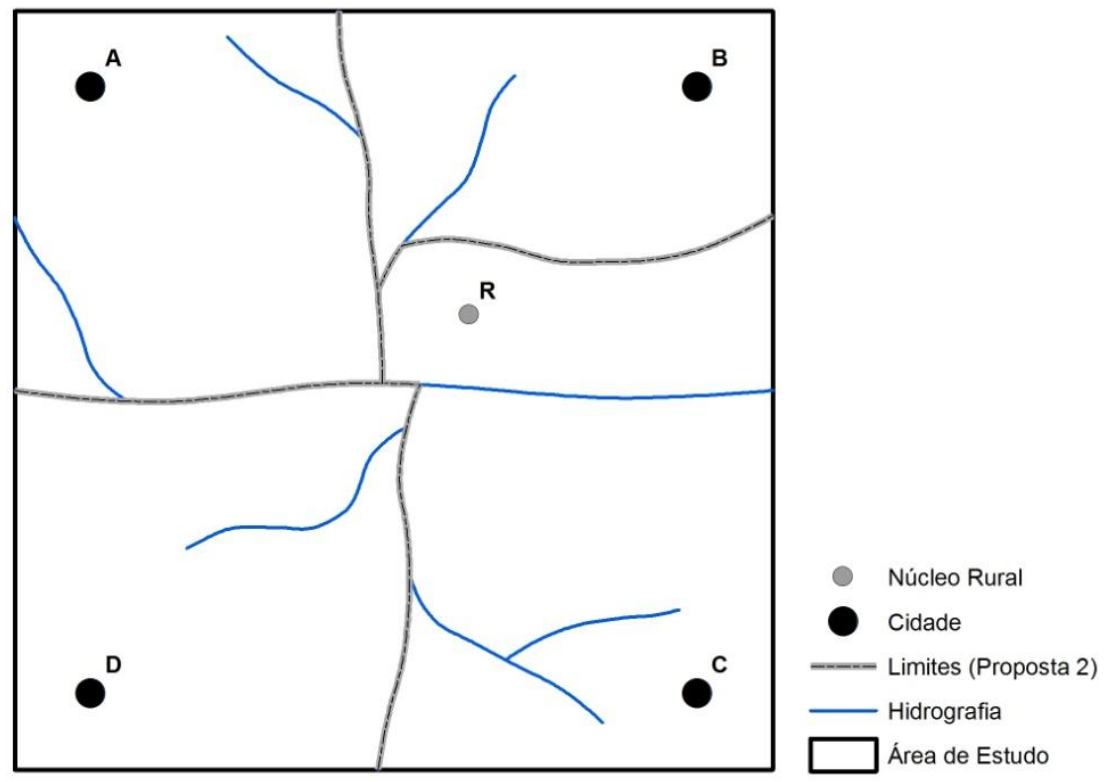

Figura 3.2-4 - Modelo - Limites (Proposta 2). Fonte: Elaborado pelo autor

A avaliação destas duas propostas demonstra, entretanto, que os aspectos ideais de ambas, pautados pela consideração de uma harmonia de área, forma e população, mediante a consideração da tradicional opção das feições naturais para o estabelecimento de limites territoriais, são muito mais aparentes do que reais. Permitindo-nos novamente expor um questionamento, estariam estas propostas de acordo com a realidade que se efetiva no espaço? Seriam as melhores opções considerando a relação entre cidade e área de influência no âmbito municipal? O que ocorre nestes cenários nada mais é que uma cômoda opção por uma delimitação simples em detrimento de uma delimitação coerente, obrigatoriamente atrelada as reais funções do município brasileiro dentro da organização políticoadministrativa do país.

Dentro do cenário apresentado, tem-se uma situação simples: quatro cidades, sedes municipais, como áreas de concentração de serviços, e um núcleo de povoamento rural, localizado entre as mesmas e desprovido dos serviços centrais. $O$ processo de estabelecimento de limites territoriais, dentro da nossa concepção já apresentada, deve, então, estar atento a relação existente entre o núcleo e cada uma das cidades. Deve-se partir de um questionamento básico inicial: em situações de necessidade de acesso à algum serviço central, para qual cidade a população do núcleo rural tenderá a se deslocar? 
Além disso, havendo a necessidade de identificação de uma relação que apresenta o movimento como o seu aspecto principal, tona-se imprescindível a inserção de um nova camada no modelo considerado, a de representação do sistema viário (figura $3.2-5)^{18}$. Partindo do princípio de que o deslocamento de pessoas e de mercadorias ocorre, hoje, mediante a utilização de canais fixos e específicos, qualquer tipo de análise direcionada ao movimento destes não pode estar desprendida das vias de circulação. As pessoas notadamente não vão de um lugar a outro pulando muros, passando por cercas ou invadindo propriedades privadas, pelo contrário, utilizam-se de rodovias, estradas, ruas, caminhos, trilhas, etc.
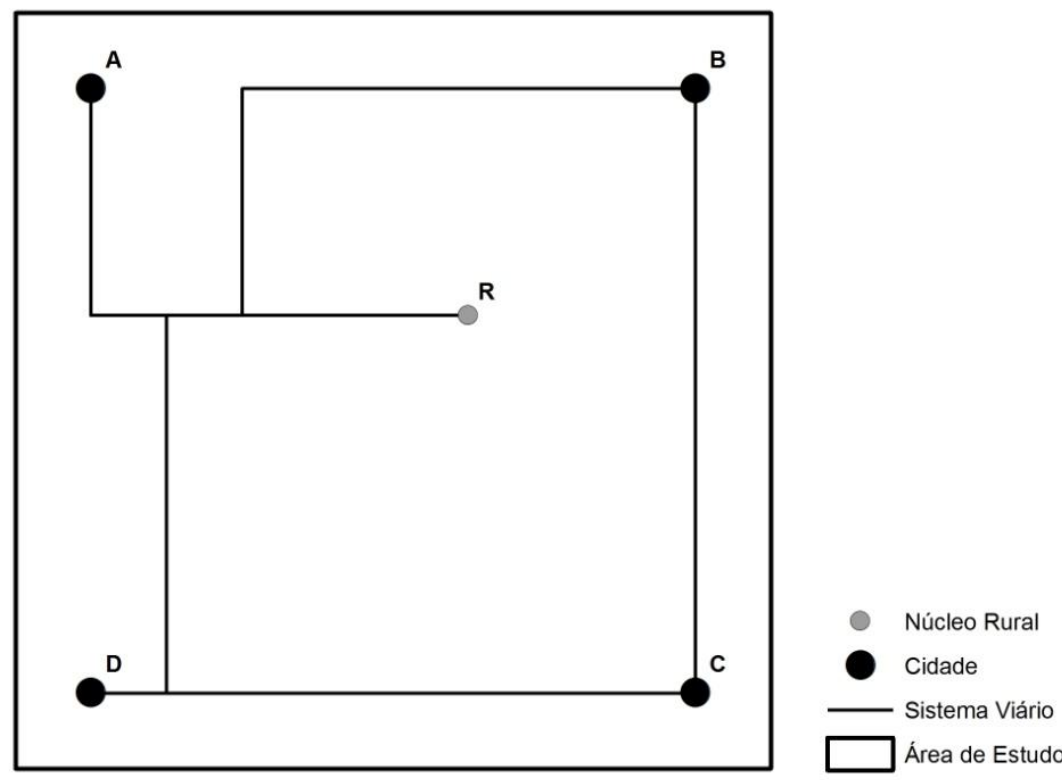

Figura 3.2-5 - Modelo - Sistema Viário. Fonte: Elaborado pelo autor

Exposta a problemática, a disposição das 5 localidades consideradas e o sistema de conexão entre elas, surge uma outra indagação fundamental: de que forma prever a escolha de uma das cidades pelos habitantes do núcleo rural? Quais os fatores possivelmente considerados? Como prever o comportamento humano nestas condições?

Uma primeira possibilidade de resolução das questões apresentadas pode ser encontrada no supracitado trabalho de Walter Christaller. Mediante a retomada de uma citação já apresentada (página 93), pode-se afirmar que, no entendimento

\footnotetext{
${ }^{18}$ No caso do modelo apresentado, optou-se pela consideração apenas das vias ligadas ao modal rodoviário, notoriamente predominante no país.
} 
christalliano, o alcance de um bem central estaria intimamente relacionado ao fator distância, ou seja, que o comportamento de um indivíduo, em meio à necessidade de deslocamento para obtenção de algum tipo de serviço (localizado em um lugar central) tenderia a ser pautado pela consideração dos elementos componentes da chamada "distância econômica" - custo de transporte, duração da viagem e conforto segundo Christaller.

O trabalho de George Kingsley Zipf intitulado "Human Behavior and the Principle of Least Effort - An Introduction to Human Ecology", de 1949, surge como outra referência de considerável relevância para a análise pretendida. Fruto de um estudo de 25 anos sobre o comportamento do ser humano, enquanto indivíduo ou em grupo, Zipf parte do questionamento de "como as pessoas deveriam reagir?" para desenvolver o seu "Princípio do Mínimo Esforço", o qual, segundo o mesmo, representaria o princípio geral de regência das ações comportamentais individuais ou coletivas do homem ou até mesmo de qualquer organismo vivo.

Among several alternatives of behavior leading to equivalent satisfaction of some potent organic need, the animal, within the limits of its discriminative ability, tends finally to select that which involves the least expenditure of energy. (TSAI apud ZIPF, 1949)

If two or more behavior sequences, each involving a different amount of work (W), have been equally well reinforced an equal number of times, the organism will gradually learn to choose the less laborious behavior sequence leading the attainment of reinforcing state of affairs. (HULL apud ZIPF, 1949)

Partindo da consideração do movimento como algo inevitavelmente presente no cotidiano de todos, uma vez que as próprias pessoas consistiriam em agregados de matéria com diferentes velocidades e direções, Zipf aponta para condicionamento do mesmo pela busca da minimização da provável taxa de trabalho necessária para a resolução de algum problema ou demanda. Como o mesmo ocorreria considerando uma estimativa futura, não apresentaria correspondência total com o menor trabalho, potencialmente problemático - uma menor quantidade de trabalho hoje poderia representar uma maior quantidade amanhã. 
And yet what is this Principle? In simples terms, the Principle of Least Effort means, for example, that a person in solving his immediate problems will view these against the background of his probable future problems, as estimated by himself. Moreover he will strive to solve his problems in such way as to minimize the total work that he must expend in solving both his immediate problems and his probable future problems. That is turn means that the person will strive to minimize the probable average rate of his workexpenditure (over time). And in so doing he will be minimizing his effort, by our definition of effort. Least effort, therefore, is a variant of least work. (ZIPF, 1949)

\begin{abstract}
...We might take the case of a student whose particular path of least effort out of his classroom would seem offhand to be the path that leads from his seat to the nearest aisle, and thence out of the door, through the hall, to the nearest stairway. On the other hand, in the event of fire, the student might conceivably prefer to run with the least time to the nearest window and adopt a path that is simultaneously a path of least work and of least time and of least distance to the ground. This path will also be a path of least effort, as estimated by himself, even at the risk of month in the hospital with a broken back. Other students may prefer to take paths through the smoke-filled corridors. These paths are also path of least effort, as estimated by the students in question. Afterwards, when, as, and if subsequent events, actually were the shrewdest gamblers in the sense of having both most correctly comprehended the nature and estimated the probabilities of the problem in their lives that was caused by unexpected fire. (ZIPF, 1949)
\end{abstract}

Além disso, a partir da adoção de uma situação hipotética de deslocamento entre duas cidades ( $\mathrm{A}$ e $\mathrm{B}$ ), Zipf aponta para a possibilidade de ocorrência de dois cenários distintos. O primeiro, caracterizado pela existência de uma única via de ligação, não apresentaria distinções entre o caminho mais curto, o mais rápido ou o mais simples, uma vez que os mesmos estariam obrigatoriamente atrelados a uma única possibilidade. Por sua vez, o segundo cenário, ao ser constituído por mais de um canal de conexão, tornaria a escolha individual efetivamente possível. Considerando que as duas cidades estivessem separadas por uma cadeia de montanhas, a opção pelo caminho mais curto (pela base da cadeia) acarretaria em um provável gasto excessivo de energia, a opção pela via mais rápida (pelo topo de cadeia) seria potencialmente perigosa, enquanto o caminho mais fácil tornaria o trajeto mais demorado e extenso. Assim, mesmo que correlacionada a uma análise particular, a escolha final não deixaria de ocorrer sob a preponderância de "parâmetros mínimos" (ZIPF, 1949).

Neste ponto, o referido autor sinaliza com a consideração do conceito de "singularidade do superlativo", ou seja, com a impossibilidade de solução de qualquer problema a partir da adoção de mais de um superlativo relacionado a 
minimização ou maximização de algo. Nestas condições, problemáticas com mais de um superlativo estariam em situação de completa indeterminação.

\begin{abstract}
As a suitable example we might take the imaginary case of a prize offered to the submarine commander who sinks the greatest number of ships in a given of interval of time; in this case, maximum number is the single superlative in the problem. Or we might alter the terms of the problem and offer a prize to the submarine commander who sinks a given number of ships in the shortest possible time; in this second case, time is the minimum, and, since it is the only superlative in the statement, the problem is quite meaningful and determinate. In either of the above examples the submarine commander can understand what the precise terms of the prize are.

Yet when we offer a prize to the submarine commander who sinks the greatest number of ships in the shortest possible time, we have a double superlative - a maximum number and a minimum time - which renders the problem completely meaningless and indeterminate, as become apparent upon reflection. (ZIPF, 1949)
\end{abstract}

A "lei" apresentada por Zipf, remetente à noção de otimização, a uma busca, intrínseca e natural, pela economia de energia despendida e pela solução de problemas através do emprego da menor taxa de esforço possível, estaria, desta forma, fortemente atrelada, mesmo que não explicitado pelo autor, a ideia de eficiência, a qual, ao ser analisada sob um viés geográfico, considerando a sua inserção no espaço, dá origem ao conceito, ainda pouco discutido, de "eficiência espacial".

Bapat (2006), partindo do entendimento da eficiência enquanto uma relação de maximização do trabalho e minimização do esforço, aponta para a sua ocorrência intrínseca a ação humana sobre o espaço. As atividades do homem, espacializadas, buscariam, intencionalmente ou não, a eficiência espacial, a qual se constituiria, desta forma, enquanto uma tendência geral do comportamento espacial da sociedade.

Spatial efficiency is an un underlying principle in human activities of various kind. Environment offers man a certain number of choices and leaves him free to decide between them. He is guided in his choice by the principle of spatial efficiency and the ensuing behavioral pattern is an outcome of his endeavor to attain it. (BAPAT, 2006) 
Dentro disto, a eficiência especial poderia ser definida como a combinação concomitante de uma maximização de uma função ou atividade e uma minimização da distância ou custos de transporte. Vista sobre outro ângulo, seria a relação, uma espécie de fração entre dois parâmetros: a maximização de uma atividade, enquanto nomeador, e a minimização da distância, enquanto denominador. (BAPAT, 2006). Segundo a autora, a eficiência espacial poderia, assim, ser expressa matematicamente da seguinte forma:

$$
E E=G \frac{A}{d}
$$

\author{
$E E$ - Eficiência Espacial \\ $G$ - Constante \\ $A$ - Atividade Espacial \\ $d$ - Distância
}

Desta forma, partindo das considerações acima expostas e retomando o questionamento acerca da tendência de deslocamento de um morador do núcleo rural contido no modelo apresentado, pode-se identificar o "fator distância" como aquele que, ao contribuir negativamente para a redução da área de influência de um lugar central, para o aumento do esforço necessário ou para a minimização da atividade espacial, deve ser superado.

Deve-se, entretanto, precisar dentro de qual entendimento está inserida esta distância. Retomando os apontamentos de Zipf (1949), a escolha de um caminho pode envolver a análise de três possibilidades: o mais curto, o mais rápido ou o mais fácil. Dentro disto, a distância a ser considerada seria aquela mensurada por quilômetros, minutos ou por preceitos subjetivos?

Para o geógrafo americano Donald G. Janelle, o tempo seria o fator-chave na relação entre o território e os meios de circulação. As estruturas locacionais das 
atividades humanas, sejam elas econômicas, políticas ou culturais, não apresentariam um situação estática e uniforme, pelo contrário, ao estarem atreladas a uma rede de linhas de transporte, variariam, espacialmente e ao longo do tempo, de acordo com modificações na capacidade de volume e velocidade do tráfego atrelado. Neste contexto, a Geografia, ao intentar analisar a relação entre dois ou mais lugares, deveria, assim como ocorrido em outras ciências como a Física, incorporar o conceito de velocidade como forma de entendimento real das relações espaciais. A simples consideração da posição ocupada por cada ponto no espaço em adição a identificação das possíveis direções de movimento entre elas seria insuficiente (JANELLE, 1968)

O "encolhimento do mundo", mediante a aproximação entre os lugares, dentro daquilo chamado por Janelle como "convergência tempo-espaço" e associado ao avanço tecnológico nos meios de transporte, poderia ser facilmente percebido, por exemplo, levando em consideração os tempos de deslocamento necessários, historicamente mensurados, entre duas cidades. No caso apresentado em Janelle (1968) - viagem entre as cidades de Edimburgo e Londres - o tempo de viagem exigido em 1776, de aproximadamente 5.760 minutos (quatro dias), cairia de forma vertiginosa ao longo do tempo. O surgimento de novos modais, cada vez mais rápidos e eficientes, tais quais o ferroviário e o rodoviário, possibilitaria, na década de 60 do século XX, a contemplação do percurso em apenas 180 minutos por via aérea (figura 3.2-6). Segundo o autor, a taxa de convergência tempo-espaço poderia ser matematicamente calculada mediante a relação entre a diferença de tempos expendidos e a diferença de anos existentes entre os períodos de ocorrência das respectivas viagens - no exemplo citado, chegar-se-ia ao valor de 29,3 minutos por ano $\left(5.760-180\right.$ minutos/190 anos $\left.{ }^{19}\right)$.

Neste contexto, ocorreria uma relativização do conceito de distância, intimamente dependente dos meios desenvolvidos pelo homem para o seu deslocamento pelo espaço. Na análise de Janelle, a distância física, medida em metros, quilômetros ou milhas, não mais consistiria em um elemento de fricção, sendo, gradativamente e irreversivelmente, preterida sobre a distância temporal, mensurada pelos minutos ou horas. Seria esta aquela que, de fato, apresentaria influência sobre um sistema de lugares centrais. A própria característica de centralidade de um determinado local, bem como o alcance de sua área de

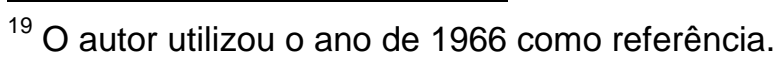


influência, estaria correlacionada, dentro da construção teórica exposta, ao conceito de utilidade locacional (figura 3.2-7), definido como:

It is a measure of the utility of specific places or areas, which in this case is defined by the aggregate time expenditure (cost or effort) in transport required for that place or area to satisfy its operational needs. Operational need refer to those natural and human resource requirements which permit the place or area to fulfill its functional roles in the larger spatial system of places and areas. The alternative possibilities of a place, either to decrease maintain, or increase its existing competitive status within the bounds of either its present spatial system of socioeconomic activities or in an expanded sphere of influence, are her considered to be functions of its locational utility. (JANELLE, 1969)

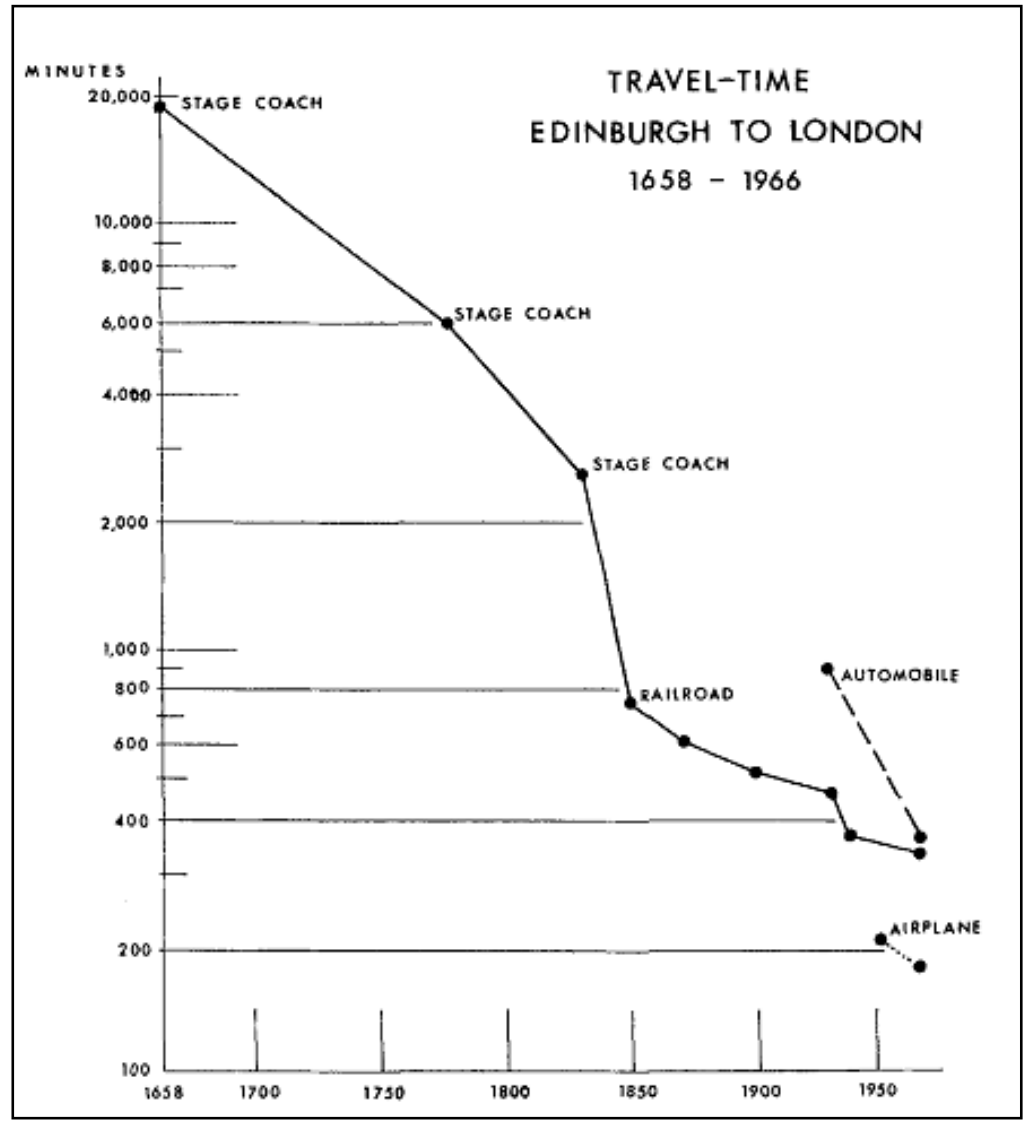

Figura 3.2-6- Tempos de viagem entre Edimburgo e Londres (1658-1966). Fonte: Janelle (1968) 


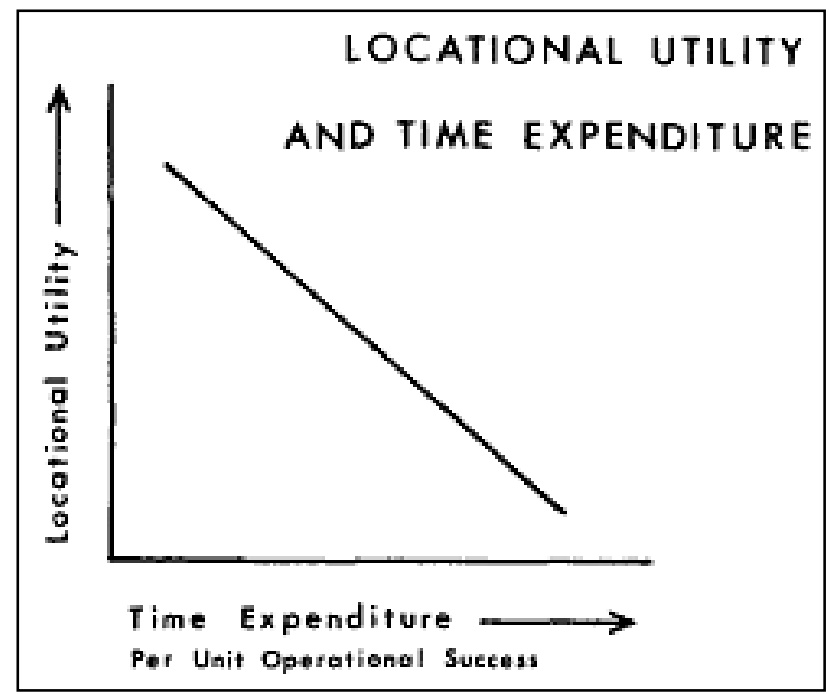

Figura 3.2-7- Relação entre a utilidade locacional e o tempo gasto. Fonte: Janelle (1969)

A utilidade locacional, por sua vez, estaria inserida dentro de um processo de reorganização espacial, caracterizado pelas adaptações dos lugares, e de suas respectivas estruturas e características sociais, econômicas e políticas, às mudanças ocorridas na conectividade tempo-espaço (tempo necessário de deslocamento entre um ponto de origem e outro de destino). O modelo de estruturação e explicação deste processo, conforme apresentado por Janelle, apresentaria seis etapas principais (figura 3.2-8):

1. Demanda por acessibilidade: o surgimento de uma demanda por acessibilidade, entendida enquanto uma medida de facilidade de transferência entre lugares e áreas, seria o início do ciclo. Em outras palavras, buscar-se-ia uma redução do esforço de transporte expendido, algo que contribuiria para o aumento da utilidade locacional;

2/3. Desenvolvimento tecnológico/Inovações nos transportes: a busca pelo aumento da acessibilidade acarretaria na utilização de novos métodos e tecnologias ligados ao transporte, os quais poderiam envolver um veículo mais rápido, um melhor combustível, melhores condições de tráfego, etc; 
4. Convergência tempo-espaço: a utilização de inovações no setor de transportes ocasionaria, ao diminuir o tempo de deslocamento necessário entre distintos lugares, um declínio da relevância da distância e, consequentemente, no aumentando da convergência entre os locais, agora mais próximos;

5. Adaptações espaciais as mudanças na organização tempo-espaço centralização e espacialização: aumento da acessibilidade, inovações nos transportes e aumento da convergência tempo-espaço contribuiriam para alterações e adaptações espaciais. Enquanto alguns locais apresentariam especialização em determinado segmento econômico, outros aumentariam seu grau de centralização, expandindo sua área de influência bem como a dependência da região do entorno.

6. Interação espacial: centralização e especialização seriam características de uma situação de maior interação espacial entre os lugares, de aumento da interdependência entre os mesmos. Este cenário seria sucedido por uma nova demanda por acessibilidade, reiniciando assim o ciclo.

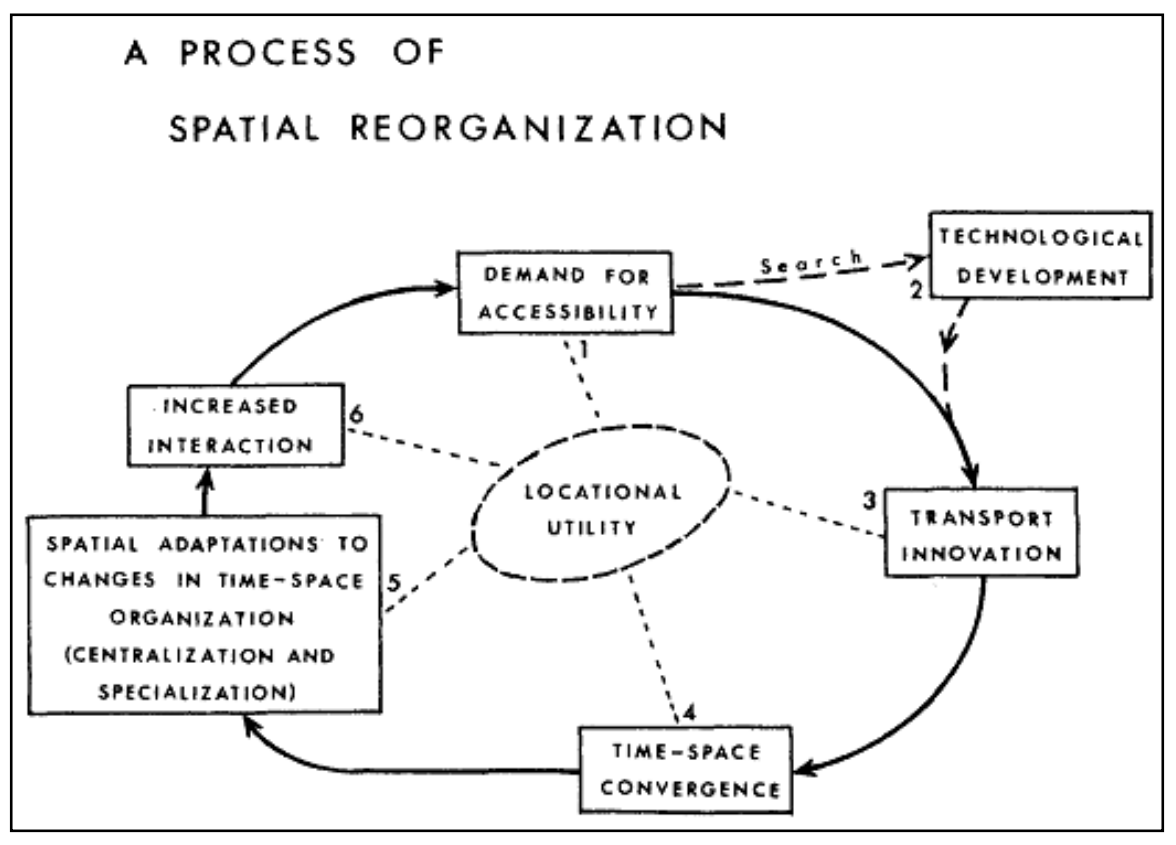

Figura 3.2-8- Modelo de reorganização espacial. Fonte: Janelle (1969) 
É possível, entretanto, que exista algum tipo de questionamento a respeito da possibilidade de ocorrência de entendimentos e percepções individuais respeito do valor do tempo, os quais, segundo Janelle (1969), seriam perfeitamente aceitáveis e esperados. O que deve estar claro, contudo, é que a adoção de um modelo - como o de Janelle ou o apresentado neste trabalho - não permite a consideração de todos os critérios ou valores individuais. $O$ universo de possibilidades invalidaria qualquer um deles. A referência a ser adotada é o comportamento racional do homem, o qual, ao estar inserido dentro de um encadeamento lógico e previsível, torna possível a identificação de tendências.

Em adição a isto, torna-se imprescindível a identificação da complexidade da consideração de escolhas que envolvam parâmetros claramente subjetivos, tais quais o caminho mais fácil de Zipf ou o conforto elencado pro Christaller. De que forma quantificá-los? Eis a dificuldade prática de utilização de qualquer um deles dentro do modelo aqui desenvolvido.

De acordo com o exposto, dentre as três possibilidades elencadas por Zipf, a escolha pela distância temporal ou, em outras palavras, pelo caminho mais rápido, parece-nos a mais lógica. Torna-se possível, então, uma expansão de nossas premissas iniciais: Se a área de influência de uma cidade (pretenso território municipal) apresenta os meios de circulação enquanto parâmetro-chave para a sua delimitação espacial, e estes, por sua vez, apresentam fluxos orientados primordialmente pela busca de percursos mais rápidos, a mesma deve ser definida, então, pelo conjunto espacial dos pontos temporalmente mais próximos da respectiva sede e em relação àquelas existentes no entorno. $O$ limite corresponderia, desta forma, a uma linha isócrona, tomando como referência o tempo de deslocamento para cada uma das cidades vizinhas.

Neste contexto, a simples representação do sistema viário para o modelo adotado (figura 3.2-5), desprovida de uma qualificação das vias existentes, não permite uma análise coerente e realista das possibilidades de deslocamento entre $R$ e A, B, C ou D. Uma rodovia, uma estrada vicinal ou um caminho rural, ao apresentarem condições de tráfego distintas e, consequentemente, influenciarem sobre a velocidade de transporte, não podem ser consideradas sob um mesmo patamar, pelo contrário, devem estar claramente diferenciadas em um sistema hierárquico. Dentro dos propósitos já reiterados deste trabalho, de uma construção 
simplificada, porém não simplória, do desenvolvimento teórico pretendido, considerar-se-á, então, para o referido modelo, apenas dois tipos de vias (rodovias e estradas), também idealizadamente dispostas (figura 3.2-9).

Resolvido este "problema", torna-se possível a reflexão acerca das ferramentas técnicas passíveis de utilização para a identificação e representação da pretendida linha de equidistância temporal entre as quatro cidades existentes no cenário modelado. Em um primeiro momento, deve-se ter em mente que a intentada linha apresenta caráter virtual, não existindo na realidade concreta sobre a superfície, tendo, portanto, de ser estimada. Para isso, é necessário, porém, a inserção de uma última informação no modelo. Sendo o tempo matematicamente calculado através da divisão do espaço percorrido pela velocidade de deslocamento, deve-se, além de diferenciar as vias, apresentar os valores de velocidade possivelmente praticados nas mesmas. Aqui, considerando apenas a velocidade máxima permitida e, a ocorrência de deslocamento somente por veículos automotivos, notadamente predominantes, adotar-se-á os valores de $100 \mathrm{~km} / \mathrm{h}$ e 60 $\mathrm{km} / \mathrm{h}$ para as rodovias e estradas, respectivamente.

Têm-se, assim, a configuração final do modelo apresentado: uma área geometricamente quadrada (10 km de lado), contendo quatro cidades e um núcleo rural, interligados por rodovias e estradas, sobre as quais são permitidas as velocidades máximas de 100 e $60 \mathrm{~km} / \mathrm{h}$.

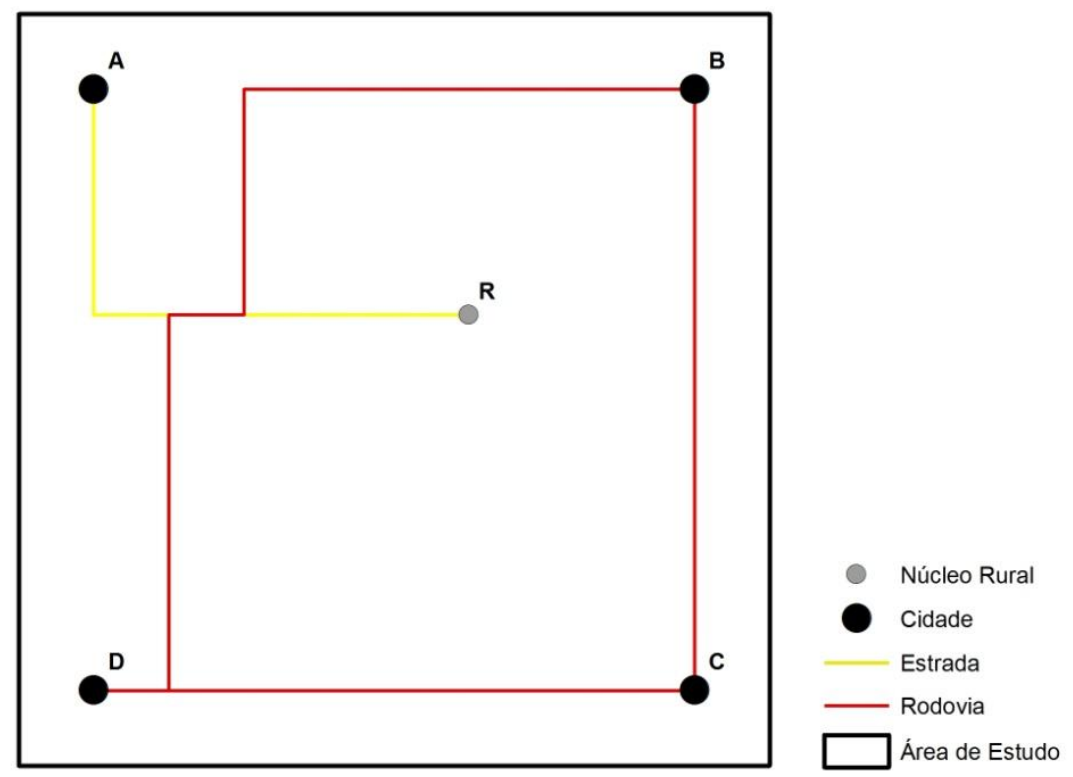

Figura 3.2-9 - Modelo - Tipologia das Vias. Fonte: Elaborado pelo autor 
Neste cenário, de que maneira seria possível identificar as isócronas almejadas? Embora o cálculo do tempo de deslocamento entre pontos localizados sobre o sistema viário seja algo relativamente simples (distância física dividida pela velocidade de deslocamento), a questão a ser solucionada passa pela transformação da distribuição destes dados, pontuais, para toda a superfície da área de estudo. Posteriormente a isto, torna-se necessário a identificação, dentro desta superfície "derivada", dos pontos e das feições lineares atreladas a equidistância entre as sedes vizinhas. Dentro disto, a utilização de um Sistema de Informações Geográficas (SIG), bem como de suas ferramentas de interpolação e álgebra de mapas, parece-nos tecnicamente correto, simples e acessível.

Segundo Matos (2008), os métodos de interpolação seriam "aqueles que permitem a transformação de um conjunto de valores pontuais, assumidos como pontos de amostra de uma grandeza de variação contínua, numa superfície de valores de grandeza em análise". De forma prática, seriam constituídos por uma matriz com valores de células preenchidos a partir de valores conhecidos de outras células ou amostra de pontos (MATOS, 2008). Eis a saída técnica para a primeira necessidade exposta acima.

A álgebra de mapas (ou álgebra de campos), por sua vez, consistiria em "um conjunto de operadores onde as variáveis manipuladas são campos geográficos" (BERRY apud BARBOSA, 1999). A análise espacial correlata é possibilitada pela utilização de operações matemáticas sobre mapas, tratados enquanto variáveis individuais e sobre os quais são aplicadas, de forma homogênea, as funções definidas (BARBOSA et al, 1998). Eis a saída técnica para a segunda necessidade exposta acima.

Desta forma, utilizando uma plataforma SIG (e as ferramentas correlatas de interpolação e álgebra de mapas) e, partindo de uma amostra de tempos de deslocamento para A, B, C e D, calculada para um conjunto de pontos localizados sobre o sistema viário do modelo (aqui chamados de pontos de controle), regularmente dispostos, faz-se possível a construção de uma matriz de distância temporal para cada uma das sedes, bem como a identificação das linhas de equidistância temporal pretendidas (figuras 3.2-10 a 3.2-12) ${ }^{20}$.

\footnotetext{
${ }^{20} \mathrm{Um}$ maior detalhamento dos procedimentos técnicos pode ser encontrado nos Anexos.
} 


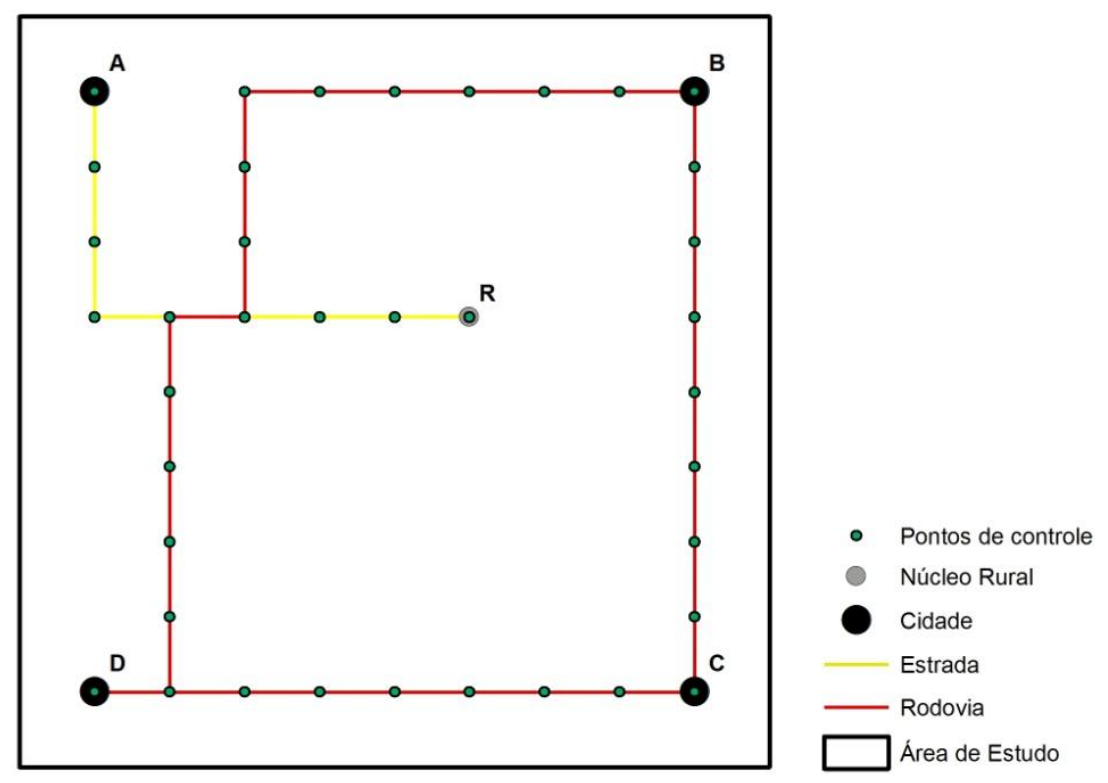

Figura 3.2-10 - Modelo - Pontos de controle. Fonte: Elaborado pelo autor

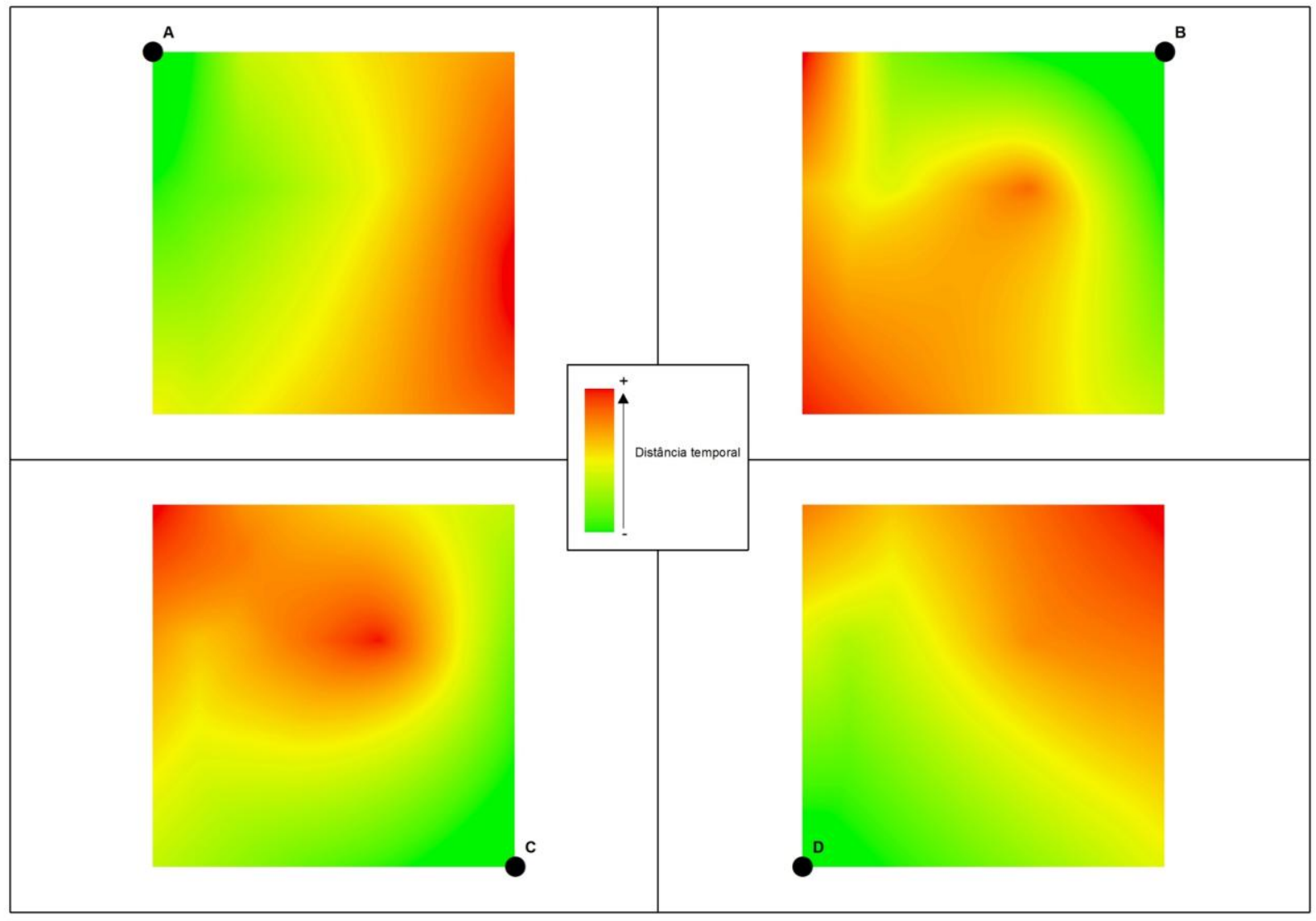

Figura 3.2-11 - Modelo - Matrizes de distância temporal. Fonte: Elaborado pelo autor 


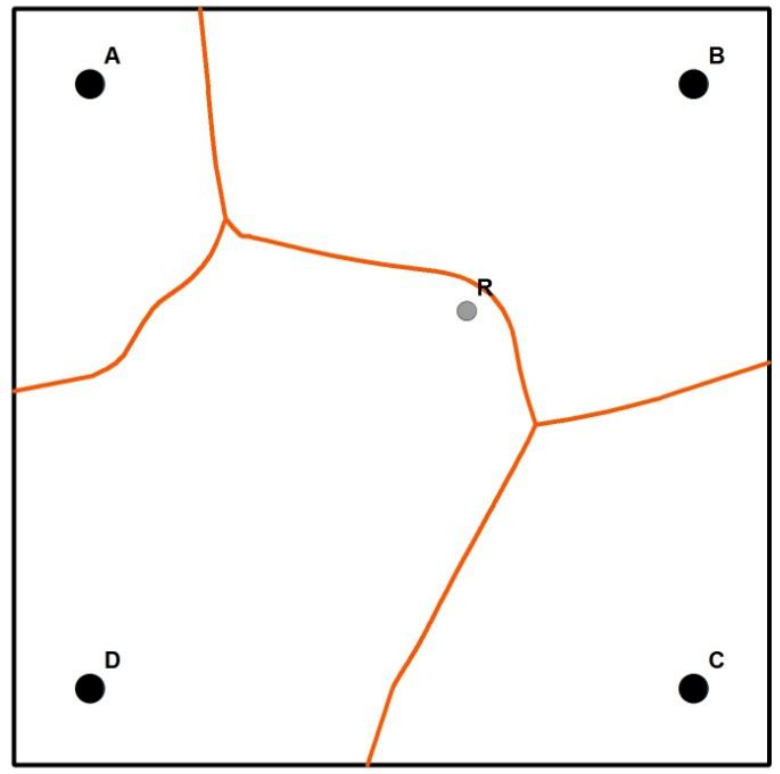

- Núcleo Rural

Cidade

Linha de equidistância temporal

Área de Estudo

Figura 3.2-12 - Modelo - Linhas de equidistância temporal. Fonte: Elaborado pelo autor

\subsection{DA ALOCAÇÃO À DELIMITAÇÃO - PROPOSIÇÃO DE ADAPTAÇÃO SOBRE UMA MALHA REGULAR}

A conclusão da etapa descrita anteriormente, correspondente a delimitação das áreas temporalmente mais próximas de cada uma das sedes consideradas, pode, em princípio, aparentar ser o ponto final da construção teórica e técnica aqui pretendida. Se o município deve ter seus limites estabelecidos a partir de linhas atreladas ao tempo de deslocamento para a sua cidade, a chegada à identificação e representação das mesmas não seria a solução de todo o processo? A resposta aqui é negativa. $O$ estabelecimento de qualquer tipo de limite territorial, seja ele externo ou interno, dentro de princípios coerentes, não pode ocorrer sem a consideração de dois aspectos fundamentais do mesmo: as fases de sua contemplação e a própria essência da linha limítrofe.

De acordo com Matos (2012), o processo de estabelecimento de uma fronteira seria sistematizado pela primeira vez por Lapradelle (1928), sendo dividido em fases de preparação, decisão e execução. Esta proposta seria, posteriormente, expandida por Jones (1945), passando a ser configurada por quatro etapas: 
1. Alocação - fase inicial de todo o processo, caracterizada pela determinação de princípios gerais a serem seguidos, bem como o estabelecimento de linhas abstratas e aproximadas;

2. Delimitação - fase de escolha do local sobre o qual, de fato, o limite será estabelecido, descrito textualmente em tratado ou lei;

3. Demarcação - fase de materialização da linha limítrofe no terreno mediante a colocação de sinais, tais quais marcos, postes, cercas, boias, etc.

4. Administração - fase de manutenção (limpeza, recuperação e substituição) e adensamento dos elementos utilizados para a demarcação.

Partindo desta sistematização e, retomando a configuração do modelo apresentado, pode-se inferir que a identificação das linhas de equidistância temporal, por si só, não representa o estabelecimento final dos limites intermunicipais objetivados. Definidas por um parâmetro central escolhido, porém de caráter abstrato, as mesmas poderiam ser qualificadas enquanto de linhas de referência, uma espécie de pré-limite, sobre o qual a fase concreta de delimitação deve estar baseada. Em outras palavras, a situação representada na figura 3.2-12 corresponderia à etapa de alocação.

Deve-se, portanto, adaptar as referidas linhas a feições de forma que permitam sua identificação e descrição, tornando possível a sua concretização em âmbito jurídico, efetivando assim a delimitação. Passe-se então a reflexão de como proceder com esta adaptação. Em um primeiro momento, a própria construção teórica até aqui desenvolvida parece ser desconsiderada. Se o território municipal deve corresponder a área de influência de sua respectiva sede, sendo esta espacialmente definida pelas linhas de equidistância temporal em relação as sedes vizinhas, a adoção de limites não exatamente correspondentes as mesmas seria uma opção coerente do ponto de vista teórico?

Jones (1945), já no início de sua obra clássica sobre as fronteiras, aponta para um elemento crucial que deve estar inserido em qualquer tipo de estudo ligado 
as mesmas: "A boundary is not merely a line but a line in a borderland". Dentro disto, podemos encontrar profunda relação com as próprias afirmações de Ratzel a respeito da fronteira. De acordo com Cataia (2007), para o geógrafo alemão, enquanto a linha poderia ser entendida como uma abstração, a zona, por sua vez, seria algo real, concreto, mais próxima à realidade.

Ao mesmo tempo em que o limite bruto pode ser considerado uma espécie de linha de referência, a partir da qual a questão da subjetividade excessiva pode ser amenizada - e aqui reside uma questão importante - deve-se ter a consciência de que o mesmo caracteriza uma situação ideal. O ajuste da linha inicial, mediante a adoção de parâmetros claros, coerentes e previamente estabelecidos, não representaria, desta forma, um distanciamento substancial da realidade, tampouco a negação dos preceitos teóricos apresentados.

Assim sendo, é na escolha dos parâmetros que reside a maior dificuldade. Seria possível, por exemplo, a escolha pela adaptação das linhas de referência aos acidentes naturais mais próximos, estando assim em congruência com tendências históricas do país, conforme explicitado no capítulo 2. Mas os problemas aqui existentes não são poucos. A própria supremacia das linhas baseadas nestas feições em relação àquelas tidas como artificiais, tacitamente reconhecida $\mathrm{e}$ raramente questionada em âmbito técnico e político, se analisada de uma forma pormenorizada, torna-se facilmente questionável.

Neste ponto, as contribuições de Theodoro Júnior (2009), embora centradas no direito de propriedade em âmbito privado, merecem destaque. Segundo o mesmo, a essência da propriedade está atrelada ao caráter de exclusividade, não podendo a coisa própria ser, ao mesmo tempo, alheia. Dentro disto, o exercício do poder exclusivo só ocorreria em meio a um pressuposto de certeza de seu objeto, sendo indispensável a precisa identificação do mesmo. Incidindo a propriedade sobre terras, torna-se imprescindível a exata identificação da porção do território que se encontra sobre o domínio de cada proprietário.

Intuitiva, destarte, é a imperiosa necessidade de que sejam convenientemente extremadas todas as propriedades, por meio de limites certos e bem definidos, capazes de evitar a confusão nos confins dos prédios contíguos e de impedir as antecipações ou invasões graduais, clandestinas ou não, que os vizinhos possam cometer reciprocamente. (THEODORO JÚNIOR, 2009) 
Mesmo que válidas parcialmente para a questão dos limites intermunicipais, haja vista não haver o exercício da propriedade neste caso, as considerações expostas acima permitem a clara identificação da necessidade de delimitações precisas. O pleno domínio sobre o território do município, e a consequente autonomia da administração municipal atrelada ao mesmo, só pode ocorrer mediante a precisa identificação da porção espacial que juridicamente the cabe, sendo inadmissíveis assim, linhas limítrofes dúbias, confusas ou inexatas. A adoção destes "limites problemáticos", ao possibilitar situações de indefinição ou de sobreposição de distintas jurisdições, contribui, conforme explicitado no capítulo 1.3, para o surgimento de litígios territoriais, bem como para o negligenciamento da obrigação de prestação de serviços públicos nas áreas lindeiras. É justamente na questão da exatidão que repousa a problemática do emprego de feições naturais para a delimitação de territórios

Tomemos como referência os dois tipos de limites naturais mais utilizados no país: cursos d'água e divisores de águas. Em relação ao primeiro tipo, a simples indicação de que o limite segue o rio $A$, o ribeirão $B$ ou o córrego $C$, não é o suficiente. Sob um ponto de vista topológico, trata-se do estabelecimento de uma linha sobre uma feição não linear, poligonal, haja vista que o curso d'água, por mais estreito que seja, constitui-se enquanto uma área de leito definido por duas margens. Dentro disto, de acordo com Jones (1945), existem quatro possibilidades, não coincidentes, para esta adaptação: a linha média (eixo), o talvegue, o canal ou as margens (figura 3.2-13).

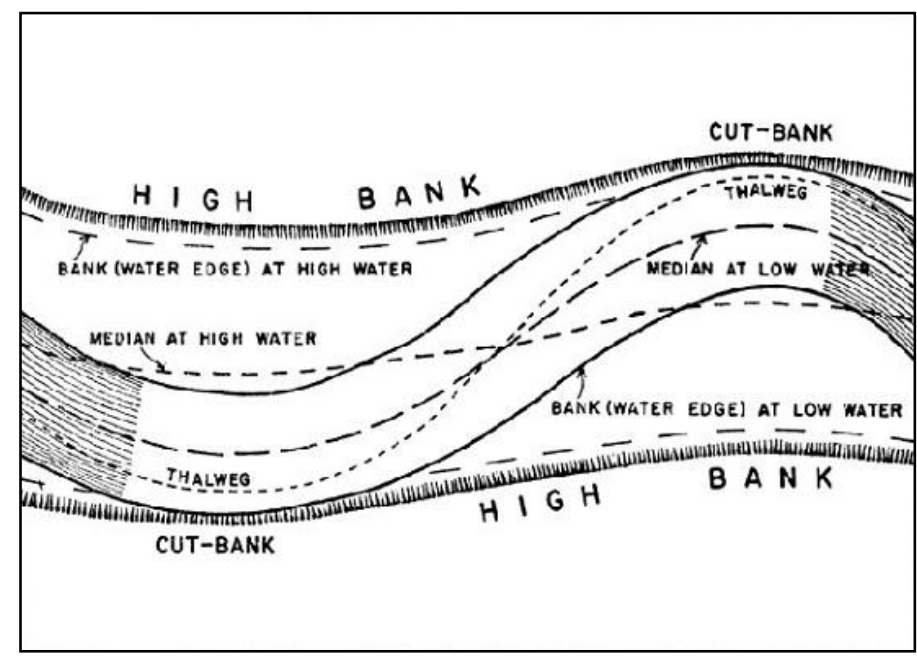

Figura 3.2-13 - Possibilidades de limites baseados em feições hidrográficas. Fonte: Jones (1945) 
Neste contexto, a explicitação, no texto jurídico de estabelecimento do limite, de qual das possibilidades será efetivamente adotada é algo primordial, contribuindo decisivamente para a não ocorrência de futuras dúvidas ou questionamentos. Entretanto, se na teoria tudo parece claro, na prática é diferente, existindo inúmeras dificuldades e situações de relevante grau de complexidade envolvidas. Adotandose, por exemplo, a linha média ou o eixo do curso d'água, não há dúvidas de que a mesma deve ser definida pelo lugar geométrico dos pontos equidistantes das margens. Isto é claro. O problema, contudo, reside em como determinar as próprias margens. Quais seriam adotadas? As existentes em período de cheias? As existentes no período seco? Um meio termo entre ambas?

Situações não menos problemáticas também podem ocorrer para as outras possibilidades. De que forma seria identificado o talvegue ${ }^{21}$ ? Não seriam necessários levantamentos de campo (batimetria, por exemplo) demorados e demandantes de um alto custo financeiro? Como identificar e delimitar o canal principal?

Além disso, deve-se ter em mente que os cursos d'água apresentam outra qualidade negativa para a sua utilização em processos de delimitação territorial: a sua instabilidade. Os rios, ribeirões, córregos, etc., além de estarem sujeitos a ações humanas de modificações (retificação, canalização, etc.), também podem apresentar variações naturais em seus cursos/leitos ao longo do tempo, comumente associadas a processos erosivos, podendo ocorrer, segundo Jones (1945), de forma rápida (acreção) ou lenta (avulsão) (figura 3.2-14).

\footnotetext{
Lateral changes of course take place in two principal ways. If the stream eats away one of its banks (often building up the other concomitantly), it is said to shift by accretion. Accretion may be defined as a lateral movement continuous in the space sense. It need no continuous in the time sense. If the stream shifts bodily, taking a new course without removing piece by piece from its bank, it is said to by avulsion. Avulsion may be defined as a lateral movement discontinuous in the space sense. (JONES, 1945)
}

Aqui, além da permanência das mesmas questões levantadas acima, surge um novo questionamento a respeito do comportamento do limite em relação à

\footnotetext{
${ }^{21}$ Linha de maior profundidade no leito fluvial (TEREZO,2008).
} 
"movimentação lateral" do curso d'água. Caso a opção seja pela alteração da linha limítrofe de acordo com a alteração do leito, opta-se também, mesmo que de forma não intencional, por uma situação de total instabilidade. Podendo o limite de hoje não corresponder exatamente ao de amanhã, têm-se um cenário impróprio para a garantia da paz pública e da efetiva administração municipal, elementos intrinsecamente dependentes da delimitação de territórios espacialmente estáveis. A outra opção, ligada a permanência do limite no leito original, independentemente das possíveis alterações do mesmo, apesar de contribuir para a uma situação de estabilidade ao longo do tempo, fica em desacordo com a própria essência inicial do processo. Se a adoção de cursos d'água para o estabelecimento de limites territoriais está baseada primordialmente no aspecto visível dos mesmos, ou seja, em sua "fácil" identificação, qual seria o sentido de uma linha limítrofe estar relacionada a um leito não mais existente?

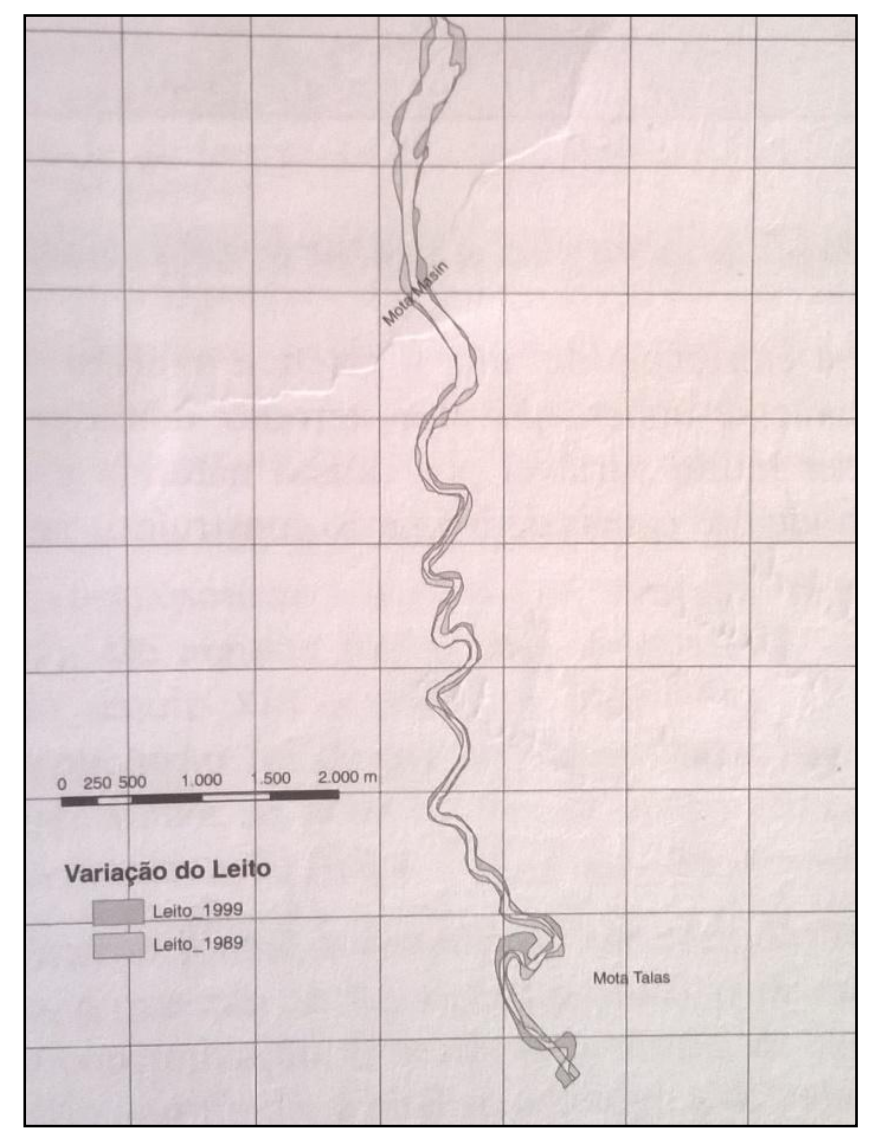

Figura 3.2-14 - Variação do rio Mota Masin (Timor Leste) entre 1989 e 1999. Fonte: Matos (2012) 
Os divisores de águas, por sua vez, apresentam basicamente os mesmos problemas. No que tange a exatidão, a identificação destas linhas de separação do escoamento de águas pluviais, delimitadoras de bacias hidrográficas, pode ocorrer basicamente de duas formas: através de levantamento em campo ou a partir da utilização de produtos cartográficos. No primeiro caso, assim como o levantamento do talvegue, o alto custo financeiro e o tempo despendido acabam por praticamente inviabilizar a alternativa. A segunda opção, mais barata e prática, surge então como a forma mais utilizada. Neste caso, verifica-se a predominância, dentro dos órgãos oficiais competentes, de técnicas manuais de delimitação a partir de dados presentes em cartas topográficas. Dentro do universo da cartografia analógica, traça-se os divisores de água a partir das curvas de nível, orientando-se pela geometria das mesmas, pelas cotas altimétricas e pela própria rede hidrográfica representada (RODRIGUES E ADAMI, 2009). Apesar de aceito nos meios acadêmico e técnico, este tipo de método apresenta, entretanto, alguns problemas a serem considerados. Em um primeiro momento, é notável a carga de subjetividade existente, uma vez que a interpretação dos elementos cartográficos pode ocorrer de forma distinta na atuação de diferentes profissionais, envolvendo a capacidade de abstração de uma representação plana para uma tridimensional (TORRES et al. 2005). Além disso, como apontam Ricci e Petri apud Valeriano e Moraes (2001), a própria base utilizada, ou seja, a carta topográfica impressa, pode apresentar limitações em suas representações, geradas pela falta de registro de informações mediante a adoção de critérios cartográficos e estéticos. As cartas topográficas, escala 1:50.000, do Instituto Brasileiro de Geografia e Estatística (IBGE), por exemplo, ao apresentarem curvas de nível em equidistância de 20 metros podem, dependendo do tipo de área considerada, podem "mascarar" algumas feições do relevo.

Configura-se, assim, uma relação de extrema dependência entre a representação do divisor de águas (e consequentemente do limite territorial a ele atrelado) e a escala do material cartográfico utilizado para tal. Cavellani (2013), ao analisar cinco díades entre municípios paulistas definidas apenas por divisores de águas, demonstra como a questão escalar incorpora um caráter de relatividade e temporariedade a este tipo de limite. Considerando as delimitações oriundas de cartas topográficas na escala 1:50.000 e 1:10.000, torna-se possível verificar as diferenças tanto em um nível qualitativo, mediante a uma análise visual (figura 3.2- 
15), como em um quantitativo, através da mensuração das áreas "deslocadas" de um município para o outro em cada situação (tabela 3.2-1).

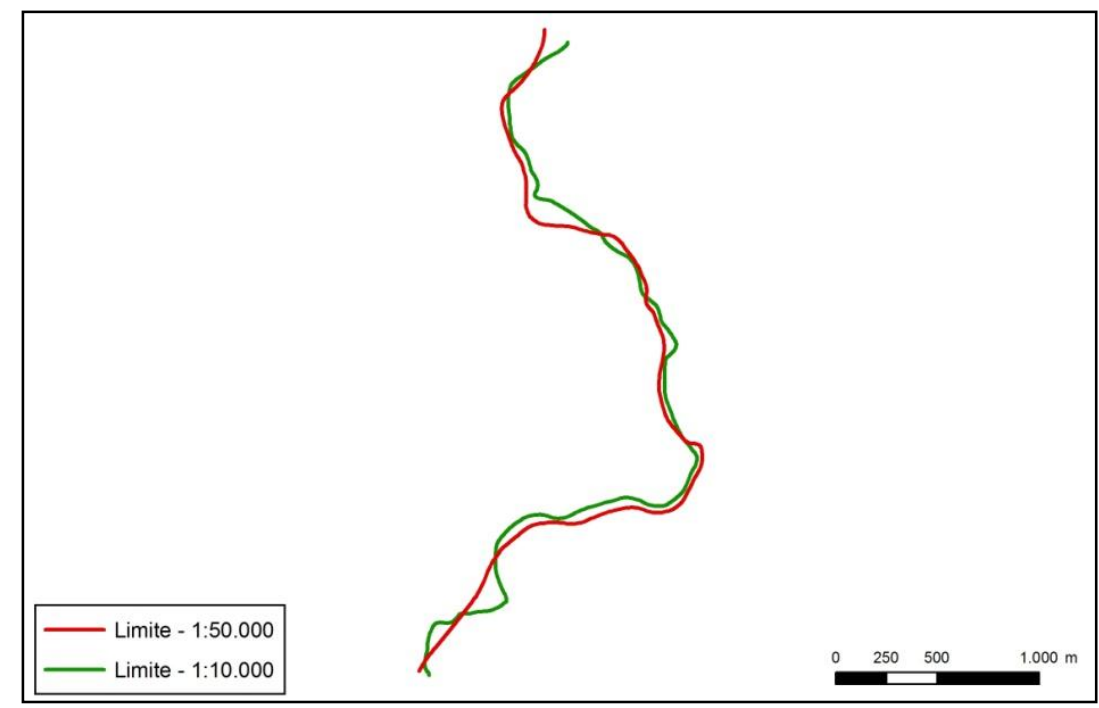

Figura 3.2-15 - Comparação entre os limites oriundos de cartas topográficas nas escalas 1:50.000 e 1:10.000 - Díade Itatiba - Vinhedo. Fonte: Adaptado de Cavellani (2013)

Tabela 3.2-1 - Diferença de áreas "deslocadas" de acordo com os limites oriundos de cartas topográficas nas escalas 1:50.000 e 1:10.000.

\begin{tabular}{|c|c|c|}
\hline \multirow{2}{*}{ Díade } & \multicolumn{2}{|c|}{ Diferença de Área } \\
\cline { 2 - 3 } & Hectares & $\%$ \\
\hline Guarei-Quadra & 64,995 & $33 \%$ \\
\hline Elias Fausto-Monte Mor & 102,158 & $15 \%$ \\
\hline Artur Nogueira-Limeira & 40,092 & $7 \%$ \\
\hline Vinhedo-Itatiba & 16,473 & $61 \%$ \\
\hline Monte Alegre do Sul-Socorro & 55,892 & $43 \%$ \\
\hline
\end{tabular}

Fonte: Adaptado de Cavellani (2013)

No quesito estabilidade, a situação dos divisores de águas também não é a ideal. Embora possam ocorrer modificações de forma natural, ligado à ocorrência de processos de recuo de cabeceiras e captura de drenagens (ROSS, 1983), as alterações artificiais são, sem dúvida, as mais comuns e problemáticas. O constante avanço das áreas urbanas, por exemplo, faz com que divisores escolhidos enquanto limites entre dois territórios municipais, em princípio não ocupados, sejam totalmente desconfigurados. Obras de terraplenagem, aterramento, nivelamento, pavimentação asfáltica, etc. acabam por modificar toda a dinâmica de escoamento e, desta forma, alteram e dificultam a identificação das linhas de interflúvio. Nestes casos, assim 
como nos cursos d'água, surge uma situação de indefinição entre a permanência ou alteração da linha limítrofe original. Ao mesmo tempo em que a escolha pelo princípio da fixidez do limite ocasiona uma situação de desencontro com a própria realidade, o ajuste constante para a adequação as novas configurações da superfície, em contrapartida, contribui negativamente para a consolidação da autonomia municipal sobre a área.

Dentro disto, em não havendo garantias de exatidão e estabilidade na utilização dos tipos de limites físicos citados, quais seriam as feições passíveis de serem empregadas para a contemplação destas necessidades? Uma possibilidade de resposta pode ser encontrada em um trecho do "Curso de Geopolítica Geral e do Brasil" de Everardo Backheuser:

\begin{abstract}
É evidentemente recurso fácil em terras sem história e desconhecidas, firmarem-se "convenções" apriorísticas, donde fronteiras que não sejam como na Europa, o resultado de vai-e-vens da supremacia guerreira de nações sempre em luta. Os círculos da Esfera Terrestre são, para casos tais, sem dúvida, em bom raciocínio, os mais convinháveis. Rápidas medidas astronômicas permitem determinar latitudes e longitudes e assim reconhecer, com segurança, se algum ponto litigioso pertence a este ou àquele dos confrontantes. Limites desse gênero restringem as possibilidades de conflitos diplomáticos ulteriores, ou mesmo os tornam impossíveis. Meia dúzia de visadas para o Sol ou para as estrêlas, decidem dúvidas. (BACKHEUSER, 1952)
\end{abstract}

Mesmo levando em consideração o contexto sobre o qual a afirmação de Backheuser esta inserida - de estabelecimento de limites territoriais em áreas despovoadas - os elementos levantados pelo mesmo são de extrema validade. As linhas astronômicas, constituídas pelos paralelos e meridianos, ao serem definidas dentro de um sistema de coordenadas geográficas pré-estabelecido, contemplam claramente os requisitos de exatidão e estabilidade intentados, haja vista que não ocorrem de forma dependente a uma escala de representação ou a qualidade de um levantamento em campo, bem como não variam ao longo do tempo. A adoção de um paralelo $X$ enquanto limite entre dois territórios, por exemplo, torna a possibilidade de dúvidas ou litígios praticamente inexistente. Escolhido o datum ${ }^{22}$ a ser utilizado, a

\footnotetext{
${ }^{22}$ Marco determinado por meios geodésicos, de alta precisão, que serve como ponto de referência para todos os levantamentos que venham a ser executados sobre uma determinada área do globo terrestre (TEIXEIRA E CHRISTOFOLETTI, 1997).
} 
determinação se um ponto pertence a este ou aquele país, estado ou município é relativamente simples, bastando apenas ser verificada a sua posição (ao norte ou ao sul) em relação a latitude de referência.

Ainda segundo o Backheuser (1952), a utilização deste tipo de limite também seria preferível caso a comparação ocorresse com as linhas geodésicas, uma outra possibilidade de feição artificial passível de utilização. Estas, ao estarem atreladas a um ponto inicial e final de amarração, acabariam por recair nos mesmos problemas citados para os acidentes naturais. A adoção de referências relativamente desconhecidas, seja em sua existência ou em sua posição, aliada a uma possível variação natural ao longo do tempo, não contribuiria para a eliminação da dúvida, tampouco para uma delimitação precisa.

Paralelos e meridianos não são, entretanto, uma proposição inédita, tampouco recente, para a delimitação territorial. A expansão marítima europeia, levada a cabo no século XV principalmente por portugueses e espanhóis, ao se deparar com um vasto espaço a ser explorado e colonizado, tornou necessária a prévia repartição deste novo mundo entre as duas grandes potências da época, a qual seria contemplada pela assinatura do Tratado de Tordesilhas, em 1494. De acordo com o mesmo, todas as áreas ocidentais ao meridiano localizado à 370 léguas das ilhas de Cabo Verde passariam a pertencer a Espanha, enquanto todas as áreas orientais ao mesmo passariam ao domínio de Portugal. Um meridiano seria, assim, a feição utilizada para o estabelecimento de uma das fronteiras mais clássicas e famosas da história.

Atualmente, embora o panorama mundial apresente o predomínio da utilização de acidentes naturais para o estabelecimento dos limites, sejam eles externos ou internos, paralelos e meridianos predominam na malha territorial em alguns países específicos, notadamente aqueles de colonização anglo-saxônica $A$ díade EUA-Canadá, por exemplo, segue pelo paralelo $49^{\circ}$ Norte em boa parte da extensão de seu trecho principal, e pelo meridiano $141^{\circ}$ Oeste em seu trecho norte (Alasca). As próprias divisas entre os estados e os condados estadunidenses, principalmente aqueles da região do meio oeste, por sua vez, também apresentam grande predominância das linhas de latitude e longitude, confirmando assim uma situação de consolidação deste tipo de limite na divisão territorial do país (figura 3.216 e $3.2-17)$. 


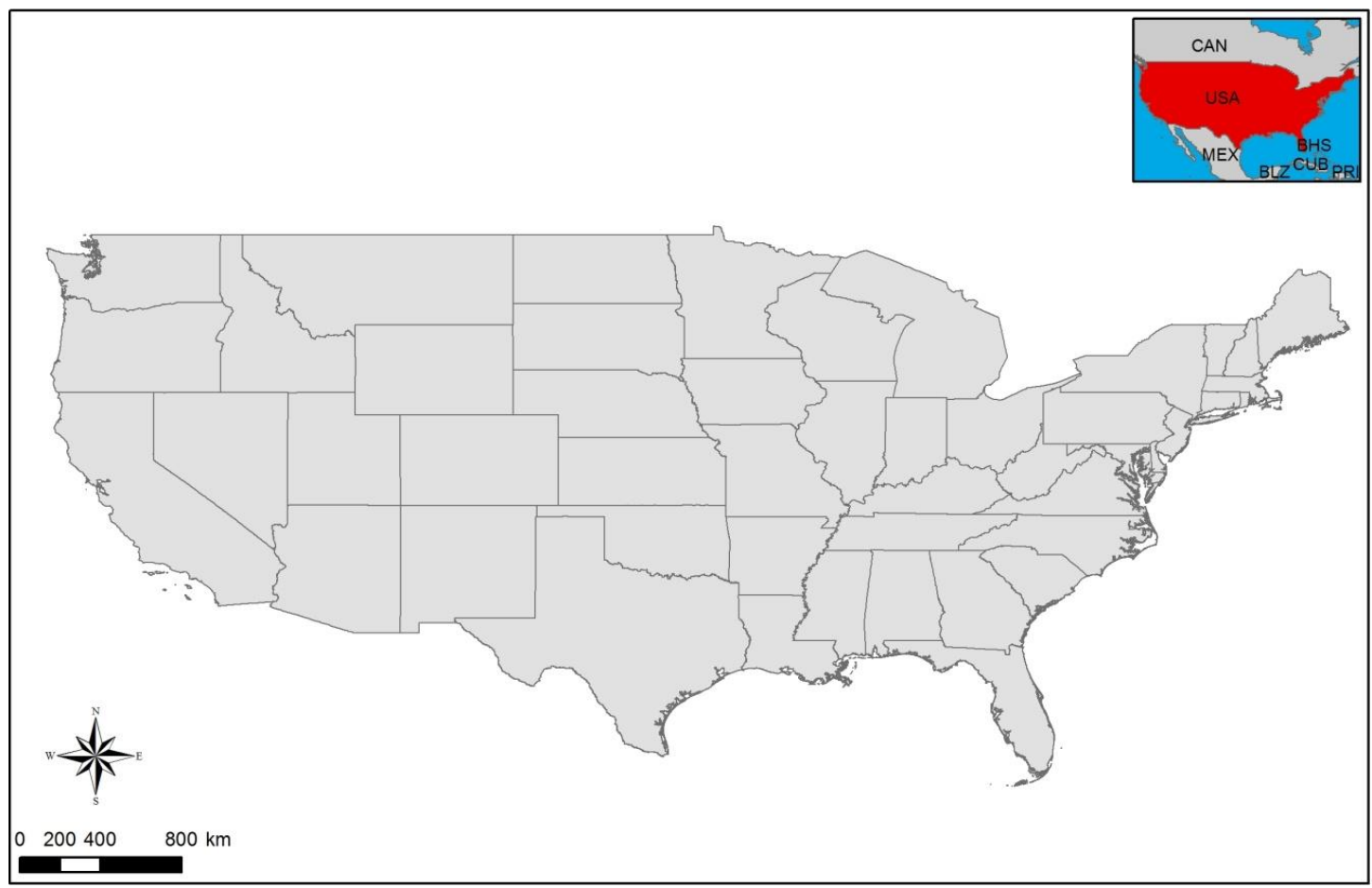

Figura 3.2-16 - Unidades da Federação dos Estados Unidos da América (exceto Alasca e Havaí). Fonte: Elaborado pelo autor

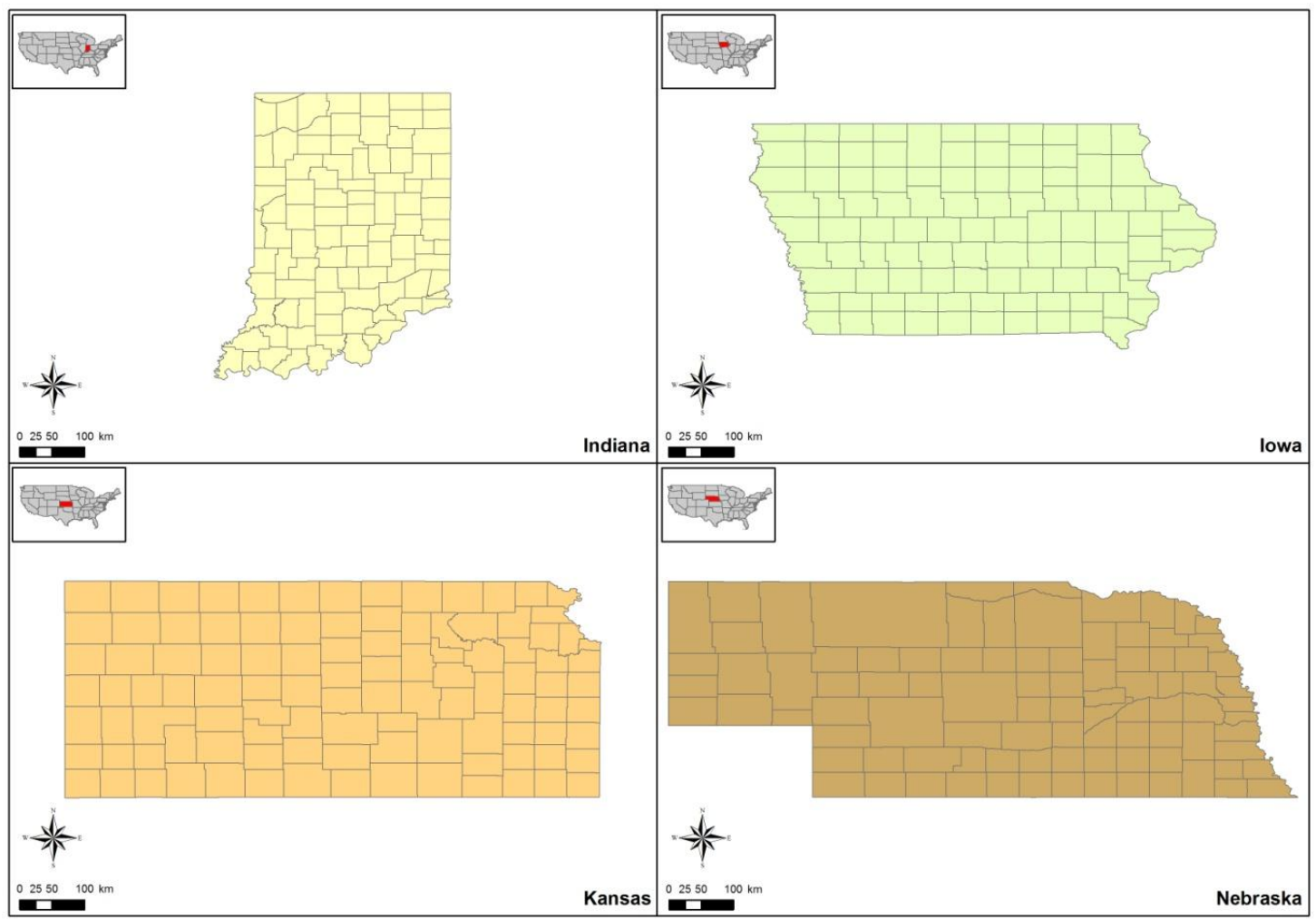

Figura 3.2-17 - Limites internos dos estados de Indiana, lowa, Kansas e Nebraska. Fonte: Elaborado pelo autor

A própria história nacional apresentaria, ao longo dos séculos $X V, X V I$ e $X V I I$, a ocorrência destes tipos de linhas no esboço de nossas fronteiras, sejam elas 
externas ou internas. Além da permanência do próprio meridiano de Tordesilhas enquanto fronteira continental até 1750 , os paralelos seriam utilizados para o desenho territorial das Capitanias Hereditárias, embriões das posteriores províncias e estados do país, estendendo-se da costa até o referido meridiano (figura 3.2-18).

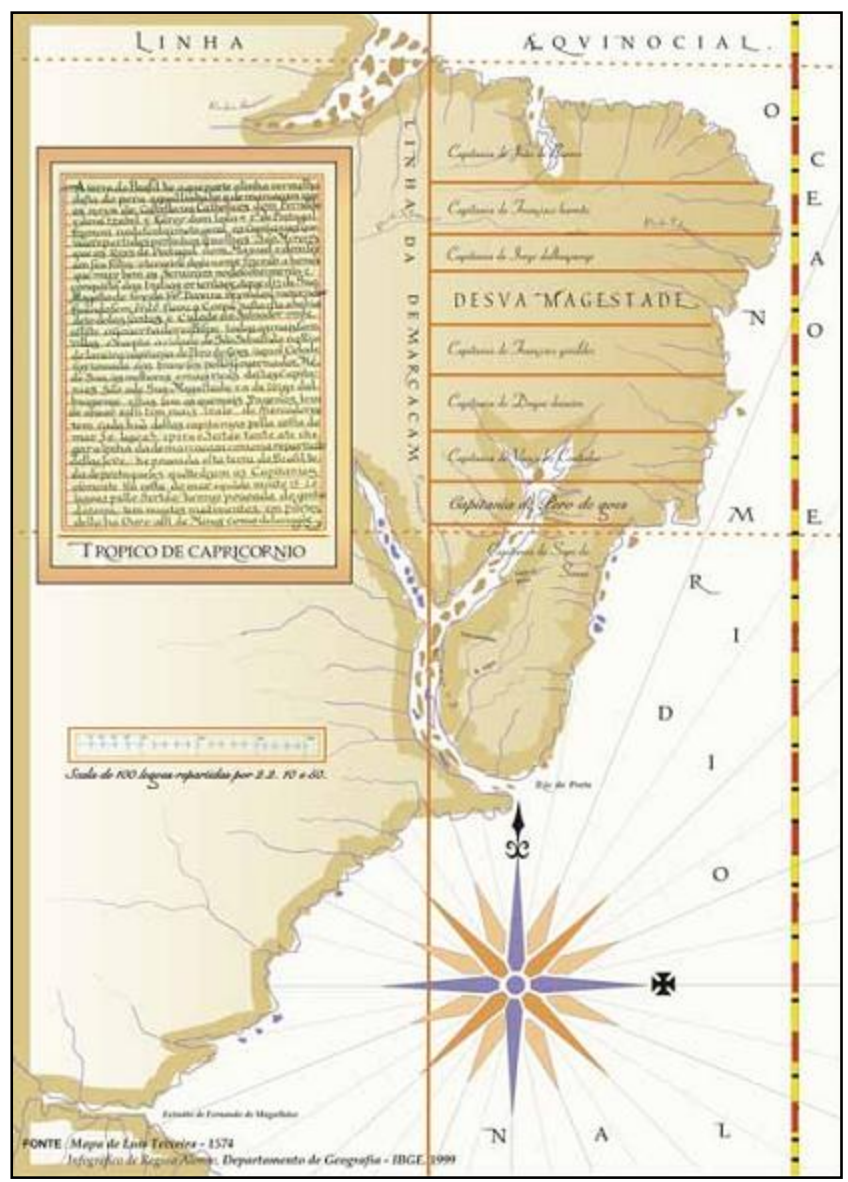

Figura 3.2-18 - Meridiano de Tordesilhas e os paralelos delimitadores das Capitanias Hereditárias. Fonte: IBGE (2001)

No panorama atual, embora tenham sido paulatinamente substituídas por linhas atreladas a acidentes físicos, fruto principalmente de uma tradição herdada da colonização, os paralelos e meridianos ainda podem ser encontrados em nossos limites internacionais, interestaduais ou intermunicipais. No primeiro caso, estão presentes nas díades setentrionais, especificamente naquelas com a Colômbia, Peru e Bolívia.

Em âmbito "estadual", um dos casos mais emblemáticos é o do território do Distrito Federal, delimitado por um conjunto de paralelos e meridianos aliados a alguns rios. De acordo com a Lei Federal ${ }^{\circ} 2.874$, de 19 de setembro de 1956: 
Art. 10 - A Capital Federal do Brasil, a que se refere 0 art. $4^{\circ}$ do Ato das Disposições Transitórias da Constituição de 18 de setembro de 1946, será localizada na região do Planalto Central, para êsse fim escolhida, na área que constituirá o futuro Distrito Federal circunscrita pela seguinte linha:

Começa no ponto da Lat. $15^{\circ} 30^{\prime}$ S e long. $48^{\circ} 12^{\prime} \mathrm{W}$. Green. Dêsse ponto, segue para leste pelo paralelo de $15^{\circ} 30^{\prime}$ S até encontrar o meridiano de $47^{\circ}$ e $25^{\prime} \mathrm{W}$. Green. Dêsse ponto segue o mesmo meridiano de $47^{\circ}$ e $25^{\prime} \mathrm{W}$. Green, para o sul até o Talweg do Córrego de S. Rita, afluente da margem direita do Rio Preto. Daí pelo Talweg do citado córrego S. Rita, até a confluência dêste com o Rio Preto, logo a juzante da Lagoa Feia. Da confluência do córrego S. Rita com o Rio Preto, segue pelo Talweg dêste último, na direção sul, até cruzar o paralelo de $16^{\circ} 03^{\prime} S$. Daí, pelo paralelo $16^{\circ} 03^{\prime}$ na direção Oeste, até encontrar o Talweg do Rio Descoberto. Daí para o norte, pelo Talweg do Rio Descoberto, até encontrar o meridiano de $48^{\circ} 12^{\prime} \mathrm{W}$. Green. Daí para o Norte pelo meridiano de $48^{\circ} 12^{\prime} \mathrm{W}$. Green, até encontrar o paralelo de $15^{\circ} 3^{\prime}$ Sul, fechando o perímetro.

Em relação ao contexto dos limites intermunicipais, embora a mensuração de todos os casos não tenha sido feita, haja vista o tempo necessário para a análise de todas as díades que envolvem os atuais 5.570 municípios do país, é possível apontar o estado de Rondônia como aquele em que os limites latitudinais e longitudinais ocorrem de forma mais destacada na malha territorial municipal. Dos 52 municípios rondonienses, 31 apresentam paralelos ou meridianos citados explicitamente nas definições jurídicas de seus territórios, aproximadamente $60 \%$ do total. Além disso, este tipo de limite ocorre em 30 das 124 díades intermunicipais (22\%), totalizando 842 quilômetros de extensão ${ }^{23}$ (figura 3.2-19).

A escolha deste tipo de feição limítrofe, entretanto, assim como os demais, não está isenta de problemas. O próprio Backheuser (1952), defensor supracitado dos paralelos e meridianos, já apontava que estas "linhas cegas" poderiam se deparar com obstáculos de difícil transposição para a posterior demarcação (escarpas de montanhas, áreas íngremes, florestas densas) bem como elementos antropogeográficos possivelmente problemáticos (cidades cortadas pelo limite). Trabalhos clássicos como o de Fawcett (1918) e Holdich (1916), por sua vez, citam a ineficiência enquanto barreira, a desconsideração da superfície e a dificuldade de demarcação como as principais complicações atreladas.

\footnotetext{
${ }^{23}$ Dados calculados a partir do arquivo vetorial da malha territorial municipal de Rondônia, datada de 2013, de autoria do IBGE.
} 


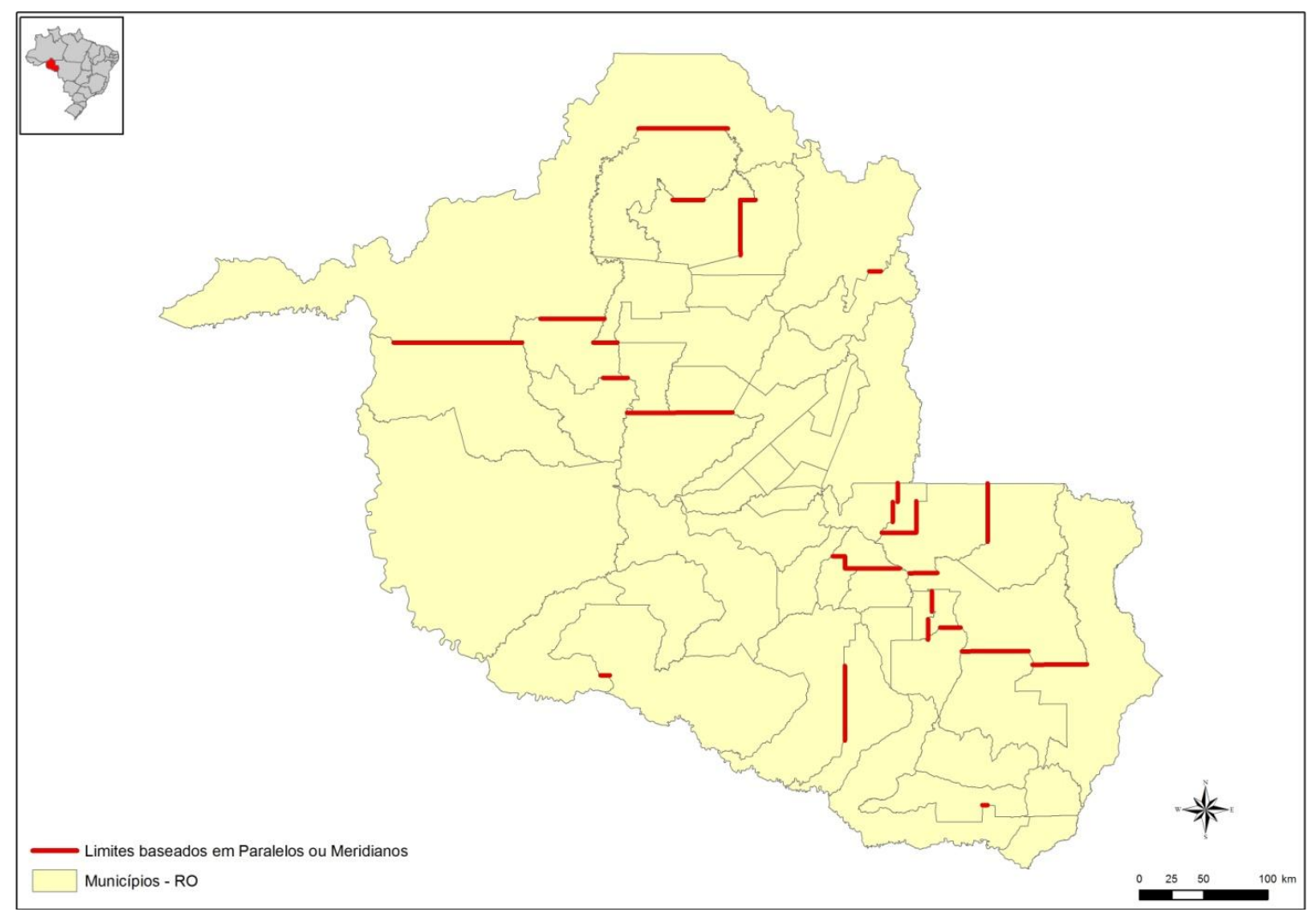

Figura 3.2-19 - Limites intermunicipais baseados em Paralelos ou Meridianos - Estado de Rondônia Fonte: Elaborado pelo autor

De qualquer forma, além do fato de dificuldades de demarcação não necessariamente indicarem um limite ruim $^{24}$ (JONES, 1945), e da necessidade de relativização da função de barreira do limite na atualidade e no contexto municipal (noção herdada de uma abordagem predominantemente militarista do território), as linhas de latitude e longitude, a nosso ver, ainda apresentariam uma maior quantidade de pontos favoráveis do que desfavoráveis a sua utilização nos processos de delimitação territorial. Além de propiciarem, como já apontado, maior exatidão e estabilidade e, desta forma, reduzirem ao mínimo as condições de litígios e dúvidas de jurisdição, a consideração dos paralelos e meridianos dentro do atual cenário técnico contribui ainda mais para esta apreciação. Se Backheuser (1952) já apontava a simples visada para o sol ou para as estrelas como um procedimento técnico adequado e confiável para a verificação da posição de um determinado ponto em relação a um limite, a grande quantidade e disponibilidade de equipamentos topográficos de alta precisão, aparelhos de posicionamento global de capacidade milimétrica e sistemas de tratamento e análise de informações georreferenciadas, tais quais os SIG (Sistemas de Informações Geográficas),

\footnotetext{
$\overline{24}$ "But demarcation difficulties do not necessarily indicate a bad boundary." (JONES, 1945).
} 
existentes na atualidade, possibilita, por sua vez, a representação indubitável das linhas limítrofes em documentos cartográficos bem como a verificação extremamente precisa in loco, caso necessário. Se a incapacidade técnica de antigamente não permitia a tranquila utilização deste tipo de limite, a situação contemporânea, além de tornar possível, contribui favoravelmente para os mesmos.

Dentro disto, tomando as linhas latitudinais e longitudinais como o parâmetro de referência para o processo de adaptação dos limites brutos do modelo apresentado, passe-se então a reflexão da forma como o mesmo pode ser realizado. Neste ponto, levando em consideração a necessidade de cerceamento da subjetividade excessiva em favor da construção de uma metodologia objetiva - uma das preocupações centrais deste trabalho - torna-se necessária a utilização de uma referência previamente estabelecida, de modo a não permitir possíveis "desvios" intencionais dos limites finais. Tomando como ponto de partida a subsequente necessidade de identificação e representação cartográfica da linha limítrofe, propõese então o emprego de uma malha regular de 30 segundos de latitude e longitude, haja vista a possibilidade de traçado das mesmas em cartas topográficas oficiais em todas escalas existentes no país, caso seja necessário em materiais em formato analógico, bem como à sua correspondência aproximada a uma grade de 1 quilômetro de lado, colocando-se assim em uma posição intermediária entre situações de extremo detalhamento e, consequentemente de elevada complexidade, ou de excessiva simplificação, potencialmente atreladas a consideráveis distorções da realidade. Além disso, havendo "cortes" de edificações, comunidades ou bairros rurais pelos medianos e paralelos limítrofes, propõe-se também a utilização de uma sub-malha de 15 segundos para a readequação dos mesmos nestes casos, buscando, desta forma, amenizar os problemas de desconsideração de elementos concretos da superfície, fator de composição das clássicas críticas aos limites baseados em linhas longitudinais e latitudinais.

O procedimento alvidrado de ajuste consistiria, assim, em 4 etapas:

1. Geração da malha de 30 segundos de latitude e longitude para a área de estudo (figura 3.2-19);

2. Cálculo, para cada quadrado da malha, da área de interface com cada um dos "territórios brutos" (figura 3.2-20); 
3. Delimitação final de cada território a partir da fusão dos quadrados em que as áreas de interface calculadas para cada um sejam superiores as demais (figura 3.2-21);

4. Verificação da existência de núcleos atingidos pelas linhas de limite adotadas e, em caso positivo, alteração das mesmas de acordo com a sub-malha de 15 segundos nas áreas em questão. Neste caso, deve-se optar pela menor alteração possível para a contemplação do objetivo almejado de alocação do referido núcleo em um único território.

Chega-se, desta forma, aos limites territoriais finais para os hipotéticos municípios A, B, C e D (figura 3.2-22), tornado possível, desta forma, uma resposta coerente e metodologicamente embasada para o questionamento inicial a respeito da alocação do núcleo rural $\mathrm{R}$ em uma das quatro áreas municipais. Retomando os pressupostos de centralidade das cidades, da relação da influência espacial das mesmas com as vias de circulação e do fator tempo na determinação das escolhas de deslocamento sobre estas, conclui-se que $\mathrm{R}$ deve estar inserido no território do município $\mathrm{D}$. 


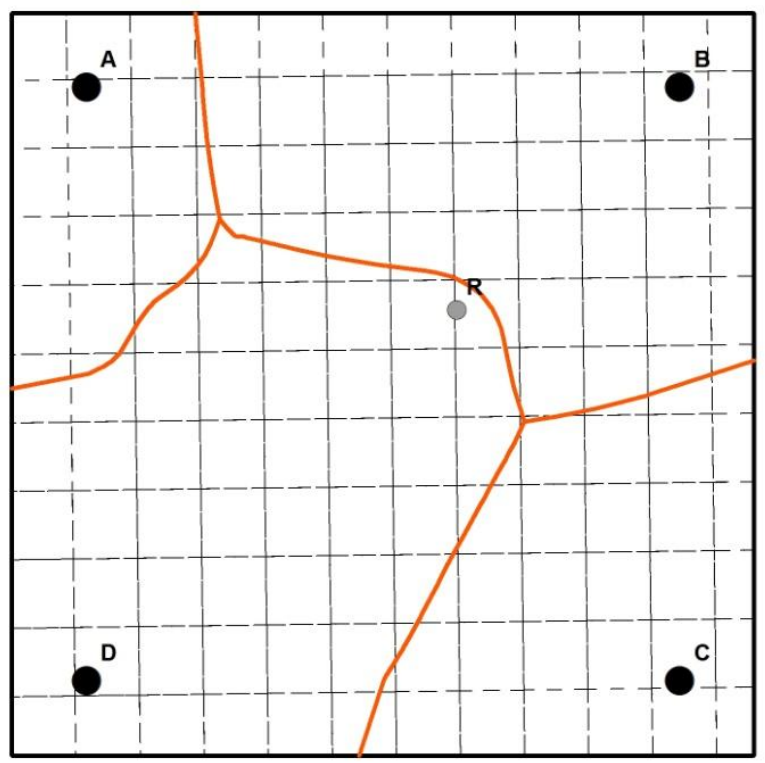

- Núcleo Rural

Cidade

- Linha de equidistância temporal

- - - Malha (30")

Área de Estudo

Figura 3.2-19 - Modelo - Malha de 30 segundos de latitude e longitude. Fonte: Elaborado pelo autor
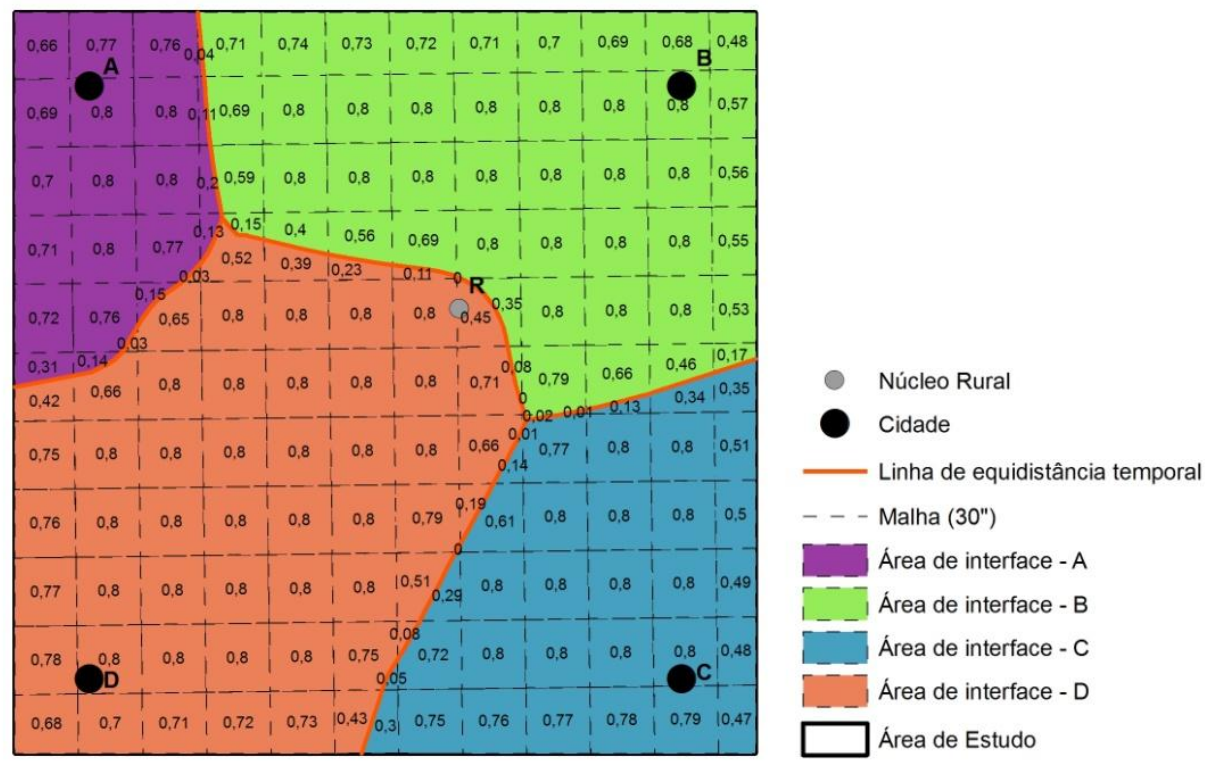

Figura 3.2-20 - Modelo - Cálculo de interface (áreas em km²). Fonte: Elaborado pelo autor 


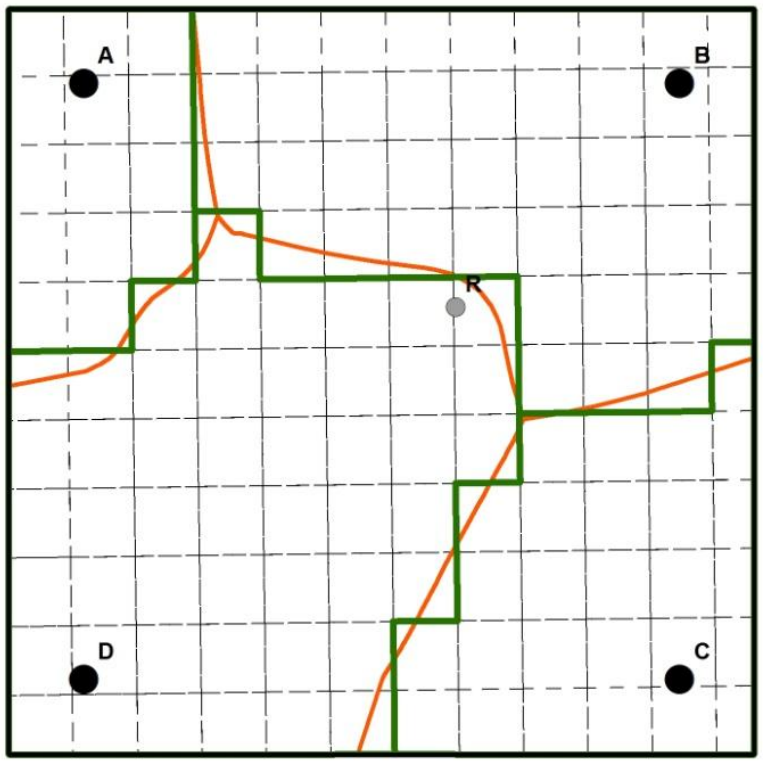

Núcleo Rural

Cidade

_ Linha de equidistância temporal

- - - Malha (30")

Limite ajustado

$\square$ Área de Estudo

Figura 3.2-21 - Modelo - Limites ajustados. Fonte: Elaborado pelo autor

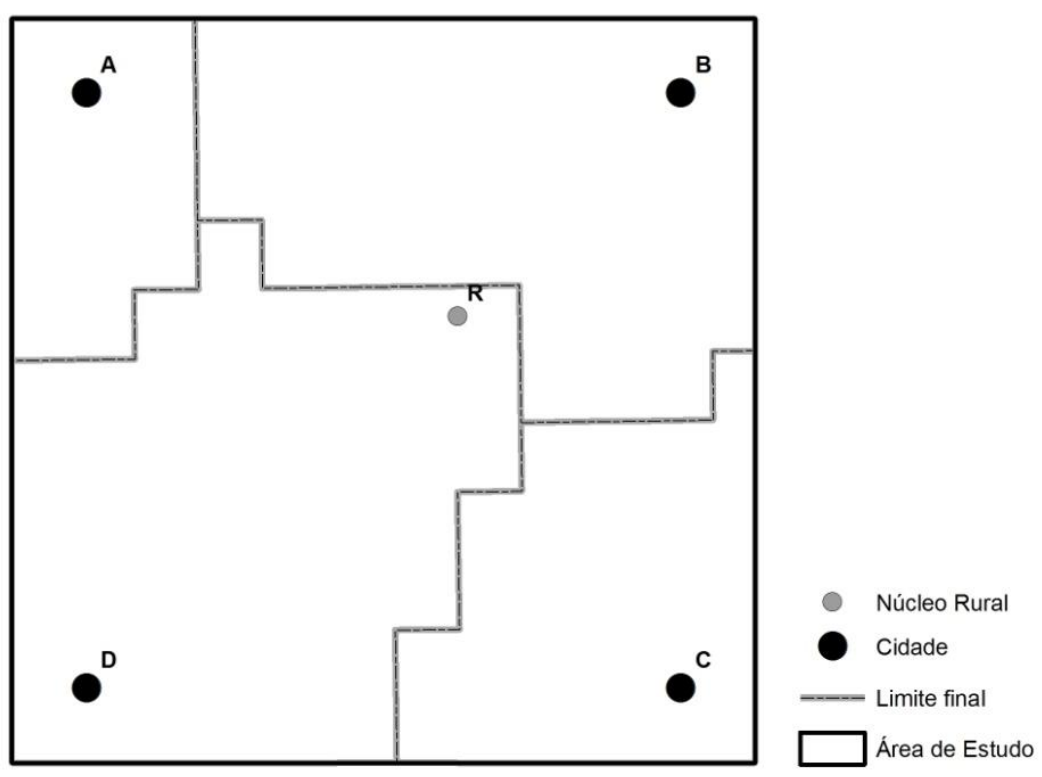

Figura 3.2-22 - Modelo - Limites finais. Fonte: Elaborado pelo autor 


\section{CONSIDERAÇÕES FINAIS}

De uma forma geral, percebe-se que a discussão sobre municípios no Brasil está pautada, quase que exclusivamente, pelo embate entre aqueles que defendem e aqueles que se opõem a criação de novos municípios. Neste contexto, os problemas do arranjo municipal nacional poderiam ser resolvidos, para o primeiro grupo, mediante a divisão de municípios muito extensos, dentro dos quais a ação estatal seria dificultada. Para o segundo grupo, entretanto, a grande quantidade de municípios acarretaria em elevados gastos com a máquina pública sem uma efetiva melhora na administração local. Uma terceira via, não mais centrada na criação ou na extinção, mas sim no rearranjo territorial, é praticamente inexistente tanto no ambiente político como no acadêmico. Se determinada comunidade deixa de ser atendida pelo respectivo governo municipal e, se a elevação da mesma a condição de sede de um futuro município não representa garantias reais de uma melhora na condição de vida da população, a sua transferência para um município vizinho poderia - e deveria - ser considerada como uma opção possível. A redelimitação seria, assim, uma alternativa a ser considerada.

Os debates ocorridos no Congresso Nacional para a aprovação do Projeto de Lei do Senado n 104 de 2014, o qual pretendia definir os critérios para a criação de municípios e assim "liberar" a retomada da divisão territorial teoricamente barrada desde a Emenda Constitucional $\mathrm{n}^{\circ} 15$ de 1996, são emblemáticos para a confirmação da situação exposta acima. Na argumentação favorável a proposta, um dos casos mais citados seria o do distrito de Castelo dos Sonhos, pertencente ao município paraense de Altamira. O discurso era simples: a referida área deveria ter o direito de se emancipar devido à falta de investimento e infraestrutura proveniente do governo municipal, haja vista a extensa distância (fator circulação como essencial) entre a referida vila e a cidade de Altamira, algo entorno de um dia de viagem pelas rodovias BR-163 e BR-230. O embate político polarizado, entretanto, não apresentou nenhuma reflexão acerca de uma possibilidade de redefinição dos limites do município de Altamira. Se o problema é a distância, porque não transferir Castelo dos Sonhos para o município vizinho de Novo Progresso, diminuindo assim a viagem vila-cidade para apenas duas horas? Porque não pensar e propor uma 
redelimitação de Altamira, haja vista a sua extensão territorial notadamente excessiva ${ }^{25}$ ?

Além disso, se o debate sobre critérios populacionais, eleitorais e econômicos para a criação de um novo município é aprofundado cada vez mais, produzindo proposições mais concretas e menos generalistas, o mesmo não ocorre no âmbito dos limites intermunicipais. Como é possível inferir a partir do histórico apresentado, se o Decreto-Lei no 311 de 1938 foi um marco para o assunto, pouco se evoluiu deste então. Se um município, para ser criado, deve apresentar uma população mínima e, se os contornos do território proposto são, de certa forma, "livres", o que impede que o desenho territorial seja direcionado muito mais para a contemplação da primeira exigência do que para a preocupação com a efetividade administrativa do município proposto? O que impede que interesses particulares determinem as divisas? O que impede que uma situação semelhante ao gerrymandering ${ }^{26}$ ocorra por aqui?

Dentro disto, como foi intentado apresentar ao longo deste trabalho, torna-se necessária uma reflexão acerca dos procedimentos de delimitação territorial utilizados para a criação de municípios no país. E é justamente neste ponto que a Geografia vem falhado. Esta, embora se caracterize como a ciência sobre a qual a temática das fronteiras tradicionalmente esteve atrelada, apresenta um negligenciamento considerável nas últimas décadas. Com o crescimento da chamada Geografia Crítica no interior da Geografia Humana a partir da década de 1970, os limites, ao se configurarem enquanto elementos essenciais para a ação do Estado, para a configuração de seu território, estando assim intrinsecamente atrelados ao poder, não estariam isentos de questionamentos por parte dos autores adeptos desta nova corrente (CASTRO et al, 2013).

Segundo Claval (1979), os limites criados e mantidos sobre o espaço, antes de qualquer intenção de defesa ou administrativa, permitem e têm a funcionalidade de controle das pessoas e de suas ações. O exercício do poder não poderia, desta forma, ocorrer de forma plena sem a delimitação de áreas dentro das quais quem

\footnotetext{
${ }^{25}$ O município de Altamira, segundo dados de 2013 do IBGE, possui uma área de $159.533,255$ km², configurando-se como o maior do país e apresentando extensão territorial superior a de 11 unidades da federação (AL, AP, CE, DF, ES, PB, PE, RN, RJ, SC e SE).

${ }^{26}$ Termo estadunidense referente a uma prática intencional de delimitação de distritos eleitorais para a obtenção de vantagens políticas.
} 
inspeciona tem acesso a todos os lugares e onde todos os pontos de saída, e consequentemente os fluxos, podem ser vigiados e controlados.

Os geógrafos criticam com frequência as divisões que as administrações criam onde se exerce o poder: os limites mantidos não levam em conta áreas homogêneas ou bacias polarizadas criadas pela natureza ou pelas atividades econômicas. Seu traçado parece arbitrário, o que leva ao comentário de que a prática administrativa é irracional. Mas não se trata disso: a finalidade das delimitações não é científica, é permitir o controle das pessoas; o importante é escolher uma boa dimensão - esta depende do que se pretende obter das populações. É mais reduzida quando o poder é exigente, mas se amplia quando a ação do senhor abarca apena um pequeno setor da vida de cada qual - como era o caso, ainda há pouco tempo, mesmo nos regimes qualificados de absolutistas: não havia representantes diretos do poder acima da subdelegação, grande como um distrito, na França de 1789. (CLAVAL, 1979)

Embora não tenhamos a intenção de negar por completo esse viés negativo da necessidade de definição de limites territoriais para o estabelecimento de um poder, faz-se necessário relativizar o mesmo. Apesar do contexto brasileiro corroborar com essa posição, haja vista a grande quantidade de municípios criados em meio a interesses particulares ou políticos, é preciso considerar também o outro lado da moeda. Se determinadas ações atreladas aos limites podem contribuir para a melhoria na vida cotidiana das pessoas, as mesmas não podem ser simplesmente descartadas.

O processo de delimitação territorial de municípios no Brasil, assim como é empreendido hoje, não contribui em nada para uma mudança de paradigma. Isto é um fato. Ao se limitar apenas à orientações generalistas e pouco efetivas, o conjunto de leis correlatas colabora, mesmo que indiretamente, para a perpetuação da apropriação da entidade municipal por grupos de poder e não para a contemplação da melhoria das condições de vida dos cidadãos locais como um todo. Mas a Geografia não pode se limitar a mera constatação e crítica desta situação. Isto é muito pouco para uma ciência deste porte. A nosso ver, cabe aos geógrafos a construção de proposições e alternativas efetivas para a solução do problema. É preciso ter a consciência de que os limites intermunicipais brasileiros podem contribuir decisivamente para a melhora da estrutura administrativa do país, para o aperfeiçoamento das suas instituições democráticas, bem como para a efetivação da 
cidadania. Esta mudança de entendimento necessita, entretanto, que os nossos municípios deixem de ser criados e delimitados em meio a critérios políticos, passando a adotar parâmetros técnicos, cientificamente embasados e transparentes. A pendência para o lado positivo ou negativo da característica funcional do limite, conforme apontada por Jones $(1945)^{27}$, depende assim dos procedimentos atrelados ao processo para o seu estabelecimento. Em não havendo os mesmos, ou sendo falha a sua constituição, a preponderância dos interesses particulares sobre o coletivo dificilmente deixará de ocorrer.

Neste contexto, a proposta metodológica aqui apresentada pretende contribuir, mesmo que de forma incipiente, para o preenchimento deste vazio acadêmico e técnico. Não existe a pretensão, entretanto, de que a mesma seja entendida como única ou perfeita, pelo contrário, acredita-se que possa vir a ser melhorada cada vez mais no interior de um pretenso adensamento da discussão a respeito do tema. Mesmo que possivelmente criticada pelo seu caráter simples (e não simplório), pela sua "ineficiência" para casos de conurbação urbana (uma única cidade divida administrativamente em duas), ou até mesmo por suas características burocráticas, em existindo algum tipo de colaboração da proposição para 0 início desta reflexão, o esforço empreendido para a elaboração deste trabalho já terá sido válido.

\footnotetext{
27 "a boundary is not an idea, nor a paragraph in a treaty, nor a line on a map, but a functional feature
} of the face of the earth". (JONES, 1945) 


\section{REFERÊNCIAS BIBLIOGRÁFICAS}

ABLAS, L.A.Q. A Teoria do Lugar Central: Bases Teóricas e Evidências Empíricas - Estudo de caso de São Paulo. São Paulo: IPE-USP, 1982.

ANCEL, J. Géographie des Frontières. Paris: Gallimard, 1938.

ARRETCHE, M. Democracia, federalismo e centralização no Brasil. Rio de Janeiro: Editora FGV, 2012.

AZAMBUJA, D. Teoria Geral do Estado. Porto Alegre: Globo, 1976.

BACKHEUSER, E. Curso de Geopolítica Geral e do Brasil. Rio de Janeiro: Laemmert, 1952.

BAPAT, S.P. Spatial Efficiency in Geography. New Delhi: Concept Publishing Company, 2006.

BARBOSA, C.C; CAMARA, G; MEDEIROS, J.S; CREPANI, E; NOVO, E; CORDEIRO, J.P.C. Operações Zonais em Álgebra de Mapas e sua Aplicação a Zoneamento Ecológico-Econômico. Anais IX Simpósio Brasileiro de Sensoriamento Remoto. Santos, 1998.

BARBOSA, C.C.F. Álgebra de mapas e suas aplicações em sensoriamento remoto e geoprocessamento. Dissertação de Mestrado. INPE. São José dos Campos, 1999. 
BLAKE, G. Geographers and International Boundaries. Boundary \& Security Bulletin, Vol.7, $n^{\circ} 4,2000$.

BOGGS, S.W. International Boundaries: A Study of Boundary Functions and Problems. New York: Columbia University Press, 1940.

BREMAEKER, F.E.J. Evolução das Finanças dos Municípios. In GIGLIO, C. O Município Moderno. Brasília: MH Comunicação, 1998.

BRADSHAW, R; GÓMEZ, R.L. Fronteras: una visión teórica em El período contemporáneo. In Aldea Mundo, ano 4, n 7, mai./out. 1999.

BRANDÃO, C.R. "No rancho fundo": espaços e tempos no mundo rural. Uberlândia: Edufu, 2009.

BRUNHES, J. Geografia Humana. Rio de Janeiro: Fundo de Cultura, 1962.

BRUSH, J.E. The Hierarchy of Central Places in Southwestern Wisconsin. Geographical Review, Vol. 43, n 3, 1953.

CARLOS, A. F. A. A cidade. São Paulo: Contexto, 2013.

CASELLA, P.B. Direito Internacional dos Espaços. São Paulo: Atlas, 2009.

CASTRO, I. E. Instituições e território. Possibilidades e limites ao exercício da cidadania no Brasil. In Revista Geosul, Vol.19, n 36, jul./dez. 2003. 
. Geografia e Política: território, escalas de ação e instituições. Rio de Janeiro: Bertrand Brasil, 2005.

CASTRO, I.E; RODRIGUES, J.N; RIBEIRO, R.W (org). Espaços da Democracia Para a Agenda da Geografia Política Contemporânea. Rio de Janeiro: Bertrand Brasil, Faperj, 2013.

CATAIA. M. A relevância das fronteiras no período atual: unificação técnica e compartimentação política dos territórios. In Revista Electrónica de Geografía y Ciencias Sociales, Vol.XI, n² 245, ago. 2007.

Fronteiras: Territórios em conflito. In Geografia em Questão, Vol.3, n 1, 2010.

CAVELLANI, C.L. Geoprocessamento e Delimitação Territorial - posibilidades metodológicas a partir dos Modelos Digitais de Elevação. Anais XVI Simpósio Brasileiro de Sensoriamento Remoto. Foz do Iguaçu, 2013.

CAZZOLATO, J.D. Novos Estados e a divisão territorial do Brasil - uma visão geográfica. São Paulo: Oficina de Textos, 2011.

CESAR, T.R.A; ALBUQUERQUE, E.S. As fronteiras na era da globalização e os novos rumos da Geografia Política. In Sociedade e Território, Natal, Vol.24, n 2 , jul./dez. 2012.

CIGOLINI, A.A. Território e criação de Municípios no Brasil: uma abordagem histórico-geográfica sobre a compartimentação do espaço. Tese de Doutorado. UFSC. Florianópolis, 2009. 
CIGOLINI, A.A; NOGUEIRA, J.F.M. Territorialização e a criação de novos estados no Brasil. XII Coloquio Internacional de Geocrítica. Bogotá, 2012.

CLAVAL, P. Espaço e Poder. Rio de Janeiro: Zahar, 1979.

CURZON OF KEDLETON. Frontiers. Romanes Lecture. Oxford: Claredon Press, 1907.

DER. Sinalização de Regulamentação de Velocidades - Procedimentos. São Paulo, 2012.

DAVIS, C; FONSECA, F. Introdução aos Sistemas de Informações Geográficos. Curso de Especialização em Geoprocessamento. UFMG. Belo Horizonte, 2001.

DUNNING, J.H. The global economy and regimes of national and supranational governance. In Businnes and the Contemporary World. n 7, 1995.

EUFRÁSIO, M.A. A Estrutura da Teoria dos Lugares Centrais de Walter Christaller. Dissertação de Mestrado. FFLCH-USP. São Paulo, 1981.

EVANGELISTA, H. A. A fusão dos estados da Guanabara e do Rio de Janeiro segundo uma perspectiva geográfica. Tese de Doutorado. UFRJ. Rio de Janeiro, 1998.

FAWCETT, C.B. Frontiers, a Study in Political Geography. Oxford: Oxford University Press, 1918. 
FERREIRA, B. F. Revisão de Literatura e análise em Planejamento de Transportes usando os Sistemas de Informações Geográficas. Trabalho de Conclusão de Curso. UFV. Viçosa, 2006.

FITZ. P.R. Geoprocessamento sem complicação. São Paulo: Oficina de Textos, 2008.

FOUCHER, M. Obsessão por fronteiras. São Paulo: Companhia Editora Nacional, 2009.

GALLI, T.B. Uso do território e fronteiras internas: 0 caso da proposta de redesenho fronteiriço do município de Holambra (SP). Tese de Doutorado. UNICAMP. Campinas, 2009.

GAMA, A. Uma ruptura epistemológica na Geografia - a Teoria dos Lugares Centrais. Revista Crítica de Ciências Sociais, № 12, 1983.

GARCIA, F.J.T. A distribuição de ICMS aos Municípios do Espírito Santo: Concentração ou Desconcentração? Dissertação de Mestrado. EBAPE/FGV. Rio de Janeiro, 2002.

GHIRARDELLO, N. À beira da linha: formações urbanas da Noroeste Paulista. São Paulo: Editora UNESP, 2002.

GIGLIO, C (org). O município moderno. Brasília: MH Comunicação, 1998.

A força dos municípios. São Paulo, 2001. 
GOODCHILD, M.F.; MASSAM, B.H. Some Least-Cost Models of Spatid Administrative Systems in Southern Ontario. Geografiska Annaler, no 52(B), 1969.

GOTTMANN, J. La politique des États et leur Géographie. Paris: Armand Colin, 1952.

A evolução do conceito de território. Boletim Campineiro de Geografia, Vol.2, no 03, 2012.

GOYCOCHÊA, C. Fronteiras e Fronteiros. São Paulo: Companhia Editora Nacional, 1943.

GREEN, F.H.W. Urban Hinterlands in England and Wales: An Analysis of Bus Services. The Geographical Journal, Vol.116, no 1,1950.

GUERRA, A. T; GUERRA, I. A. L. T. Subsídios para uma nova divisão política do Brasil. Revista Brasileira de Geografia. Ano XXII, no 02. IBGE: Rio de Janeiro, 1960.

HAGGETT, P. Analisis Locacional em la Geografia Humana. Barcelona: Gustavo Gilli, 1976.

HAESBAERT, R. Des-territorialização e identidade: a rede gaúcha no Nordeste. Niterói: Eduff, 1997.

HARTSHORNE, R. Suggestions on the Terminology of Political Boundaries (abstract). Annals of the Association of American Geographers, Vol.26, n.1, 1936. 
HOLDICH, T. H. Political Frontiers and Boundary Making. London: Macmillian and co. limited, 1916.

IBGE. Noções Básicas de Cartografia. Rio de Janeiro, 1998.

. Evolução da Divisão Territorial do Brasil - 1872-2010. Rio de Janeiro, 2001.

Glossário de Termos Genéricos dos Nomes Geográficos Utilizados no Mapeamento Sistemático do Brasil. Vol.1. Rio de Janeiro, 2010.

IGC. Municípios e Distritos do Estado de São Paulo. São Paulo: Imprensa Oficial do Estado de São Paulo, 1995.

. Municípios do Estado de São Paulo - Criação e Divisas. São Paulo, 2010.

JANELLE, D.G. Central Place Development in a Time-Space Framework. The Professional Geographer, Vol.20, 1968.

Spatial Reorganization: A Model and Concept. Annals of the Association of American Geographers, Vol.59, n.2, 1969.

JONES, S.B. Boundary Making: A Handbook for Statesmen, Treaty Editors and Boundary Comissioners. Washington: Carnegie Endowment for International Peace. Division of International Law, 1945. 
LAPARADELLE, P. La Frontiére: Étude de Droit International. Paris: Les Editions Internationales, 1928.

MACEACHREN, A.M. Compactness of Geographic Shape: Comparison and Evaluation of Measures. Geografiska Annaler, Vol.67, № 1(B), 1985.

MACEDO, R.A.M; ROCHA, J.F; SANTOS, C.A; MIRANDA, R.S. Revisão dos limites municipais do estado do Pará com o uso de geotecnologias. Anais XVI Simpósio Brasileiro de Sensoriamento Remoto. Foz do Iguaçu, 2013.

MARSITCH, M.A.P. O uso de isócronas nos Sistemas de Informações Geográficas destinado a otimizar o deslocamento das unidades móveis de atendimento de urgência no município de São Paulo. Dissertação de Mestrado. FFLCH-USP. São Paulo, 2010.

MARTIN, A.R. Fronteiras e Nações. São Paulo: Contexto, 1992.

As fronteiras internas e a "questão regional" do Brasil. Tese de Doutorado. FFLCH-USP. São Paulo, 1993.

MATOS, J. Fundamentos de Informação Geográfica. Lisboa: Lidel, 2008.

Fronteiras Terrestres - Conceitos e Aplicações. Lisboa: Lidel, 2012.

MEIRA MATTOS, C. Brasil: geopolítica e destino. Rio de Janeiro: José Olympio, 1979. 
MEIRELLES, H.L. Direito Municipal Brasileiro. São Paulo: Revista dos Tribunais, 1981.

MELO FILHO, U.V. Direito Municipal em Movimento. Belo Horizonte: Del Rey, 1999.

MONBEIG, P. Pioneiros e fazendeiros de São Paulo. São Paulo: Hucitec, 1984.

MOODIE, A.E. Geografia e Política. Rio de Janeiro: Zahar, 1965.

MORACZEWSKA, A. The changing interpretation of border functions in international relations. Revista Româna de Geografie Politica. Ano XII, n 2, nov. 2010.

MORENO, B.C.; SOUZA, L.G. Os limites de Belo Horizonte: entre o choque e o encontro das cidades. 4o Congresso Luso-Brasileiro para 0 Planejamento Urbano, Regional, Integrado e Sustentável (PLURIS). Faro, 2010.

MORRILL, R.L. Redistricting, region and representation. Political Geography Quarterly, Vol.6, n.3, 1987.

MOURA, M. C. Uso de Sistemas de Informações Geográficas no planejamento para otimização de rotas de distribuição. Dissertação de Mestrado. UFV. Viçosa, 2001.

NEWMAN, D. Into the millennium: The study of international boundaries in an era of global and technological change. IBRU Boundary and Security Bulletin, 1999. 
OHMAE, K. O mundo sem fronteiras - poder e estratégia em uma economia global. São Paulo: Makron Books, 1991.

O fim do Estado-nação. Rio de Janeiro: Editora Campus, 1996.

PARR, J.B. Frequency Distributions of Central Places in Southern Germany: A Further Analysis. Economic Geography, Vol.56, n² 2, 1980.

PINA, J.H.A; LIMA, O.A.; SILVA, V.P. Município e Distrito: um estudo teórico. CAMPO-TERRITÓRIO: Revista de Geografia Agrária, Vol. 3, n 6, ago. 2008.

PINTO, G.J. Do sonho à realidade: Córrego Fundo-MG, fragmentação territorial e criação de municípios de pequeno porte. Dissertação de Mestrado. UFU. Uberlândia, 2003.

PRESCOTT, J.R.V. The geography of frontiers and boundaries. London: Hutchinson University Library, 1965.

RAFFESTIN, C. Por uma Geografia do Poder. São Paulo: Ática, 1993.

RAMOS, R. A. R. e MENDES, J. F. G. Introdução às Teorias da Localização orientações recentes na Localização industrial. Universidade do Minho, Departamento de Engenharia Civil. 2001. 
RODRIGUES, C.; ADAMI, S. Técnicas Fundamentais para o Estudo de Bacias Hidrográficas. In Venturi, L.A.B. Praticando Geografia: Técnicas de Campo e Laboratório. São Paulo: Oficina de Textos, 2009.

ROSS, J.L.S. Considerações a Respeito da Importância da Geomorfologia na Questão dos Limites Territoriais. Revista do Departamento de Geografia (USP), Vol.1, 1983.

SAJJADUR RASHEED, K.B. The Spatial Efficiency of Administrative Units in Bangladesh. Geografiska Annaler. Series B, Human Geography, Vol.68, 1986.

SILVA, V. P; PINA. J. H. A. e LIMA. O. A. Município e Distrito: um estudo teórico. Campo-Território: Revista de geografia agrária. Vol.3, 2008.

SILVA JUNIOR, R.F. Circulação, epistemologia e a construção de uma ramo da ciência geográfica. Boletim Campineiro de Geografia, Vol.2, n 3, 2012.

SMAILES, A.E. The analysis and delimitation of urban fields. Geography, Vol.32, n 4, 1947.

SOLIMEO, M; GAMBOA, U. O Município no mundo das finanças públicas. In AFIF, G. Em buscas da melhor cidade: análises, ideias e soluções para os Municípios do Brasil. São Paulo: Scriptum Editorial, 2012.

SORRE, M. Les fondements de la Géographie Humaine. Tome II: les fondements techniques. Paris: Armand Colin, 1948. 
TEIXEIRA, A.L.A; CHRISTOFOLETTI, A. Sistemas de Informação Geográfica Dicionário llustrado. São Paulo: Hucitec, 1997.

TEREZO, C.F. Novo Dicionário de Geografia. São Paulo: Livro Pronto, 2008.

THEODORO JÚNIOR, H. Terras particulares: demarcação, divisão, tapumes. São Paulo: Saraiva, 2009.

TORRES, T.G.; PARANHOS FILHO, A.C.; RONDON, M.A.C.; LASTORIA, G.; SOUZA, A. Comparação do divisor de bacia obtido de diferentes modos: o caso de estudo da bacia do córrego Guariroba -MS. Revista de Estudos Ambientais, Vol.7, $n^{\circ} 1,2005$.

ULLMAN, E.L. Trade Centers and Tributary Areas of the Philippines. Geographical Review, Vol.50, n², 1960.

VALERIANO, M.M.; MORAES, J.F.L. Extração de rede de drenagem e divisores por processamento digital de dados topográficos. Anais X Simpósio Brasileiro de Sensoriamento Remoto. Foz do Iguaçu, 2001.

VALLAUX, C. El suelo y el Estado. Madri: Daniel Jorro, 1914.

YEATES, M. Hinterland Delimitation: A distance minimizing approach. The Professional Geographer, Vol.16, 1963.

YEUNG, H.W. Capital, state and space: contesting the borderless world. Transactions of the Institute of British Geographers. Vol.23, set. 1998. 
ZIPF, G.H. Human Behavior and the Principle of Least Effort - An Introduction to Human Ecology. Cambridge: Addison-Wesley Press, 1949.

Sítios Eletrônicos:

CIA - The World Factbook - https://www.cia.gov/library/publications/the-worldfactbook/ - acesso em 31/03/2013

Confederação Nacional de Municípios (CNM) - http://www.cnm.org.br/ - acesso em $31 / 03 / 2013$

Departamento de Estradas de Rodagem - São Paulo (DER-SP) - http:// http://www.der.sp.gov.br/ - acesso em 02/11/2013

Diretoria de Serviço Geográfico do Exército (DSG) - http://www.dsg.eb.mil.br/ acesso em 02/11/2013

Global Administrative Areas (GADM) - http://www.gadm.org/ - acesso em 31/03/2013 Instituto Brasileiro de Geografia e Estatística (IBGE) - http://www.ibge.gov.br/ acesso em 02/11/2013

Instituto Geográfico e Cartográfico do Estado de São Paulo (IGC-SP) http://www.igc.sp.gov.br/ - acesso em 02/11/2013 


\title{
6. ANEXOS
}

Todos os procedimentos técnicos empreendidos para a construção do modelo apresentado foram efetuados a partir da utilização do software ArcGIS 9.3, produzido e comercializado pela empresa estadunidense Esri.

Primeiramente, a camada de informação referente ao sistema viário, já com os tipos de via diferenciados, seria transformada em um arquivo shapefile, dentro do qual seriam calculados tanto a extensão física como o tempo de deslocamento para cada segmento existente (mediante a divisão da extensão física pela velocidade de deslocamento). Os dados obtidos seriam inseridos em campos específicos da tabela de atributos do referido arquivo vetorial.

Após um procedimento de verificação e correção topológica para a garantia da conectividade entre os vetores, converteu-se a malha viária tratada em um arquivo de rede $(\text { Network })^{28}$, a partir do qual seriam efetuados processos de roteirização (ou roteamento), definidos por Moura (2001) como:

\begin{abstract}
a busca pela melhor rota, levando em consideração não somente aspectos geográficos, mas também aspectos como restrições de horários de atendimento nos pontos a serem visitados, obstáculos e restrições nas vias, etc., utilizando-se, para isso, de dois elementos - um algoritmo (modelo de simulação e otimização) e uma base de dados apropriada (rede de representação do sistema viário). (MOURA, 2001).
\end{abstract}

O arquivo gerado, caracterizado enquanto um grafo - representação matemática de redes, formada por uma conjunto de vértices e arestas, que permitem a aplicação dos algoritmos de simulação e otimização (FERREIRA, 2006) - seria utilizado para o cálculo dos tempos de viagens entre as sedes municipais e um conjunto de pontos, localizados ao longo da malha viária, denominados enquanto "pontos de controle". Estes seriam formados por um grupo de pontos (38 no total) alocados em um espaçamento de 1000 metros ao longo de toda a rede, incluindo também os pontos referentes a cada cidade a ao núcleo rural.

${ }^{28}$ Função "New Network Dataset" 
A partir disto, mediante a utilização da ferramenta "New Closest Facility" do módulo "Network Analyst" do ArcGIS 9.3, foram calculados os tempos de viagem necessários para o percurso ponto de controle-sede municipal, considerando-se, para isso, o menor tempo possível. Neste caso, o algoritmo utilizado pelo software para os referidos cálculos é o chamado "Algoritmo de Dijkstra", comumente empregado para a solução de problemas de caminho mínimo ou de menor custo. $\mathrm{O}$ seu funcionamento pode ser entendido a partir do raciocínio desenvolvido por Davis e Fonseca (2001):

\begin{abstract}
O algoritmo considera um grafo $G$, composto por um conjunto de nós, denominado $\mathrm{N}$, e um conjunto de arcos denominado A. Além disso, são conhecidos dois nós pertencentes a $\mathrm{N}$, denominados $o$ e $d$, que são respectivamente origem e destino. Os nós são divididos em três grupos: os já visitados (conjunto $\mathrm{V}$ ), os candidatos ou de fronteira (conjunto $\mathrm{F}$ ) e os nunca visitados ou 'desconhecidos' (conjunto $D$ ). $O$ conjunto $V$ é inicializado para conter apenas o nó 0 . Os vizinhos imediatos de $O$ são colocados no conjunto $F$, sendo registrados os custos para atingi-los a partir de 0 , e os demais inicialmente pertencem ao conjunto $D$. A cada passo do algoritmo, os nós de $\mathrm{F}$ são verificados para determinar qual seria a melhor opção para expandir a pesquisa. Será escolhido e transferido para $V$ aquele nó cujo custo acumulado seja menor dentre os candidatos, e seus vizinhos serão então transferidos do conjunto $\mathrm{D}$ para o conjunto $\mathrm{F}$. A pesquisa para quando o nó $d$ for alcançado ou quando não houver mais nós a percorrer (neste caso não existe caminho viável entre $o$ e d). (DAVIS e FONSECA apud MARSITCH, 2010)
\end{abstract}

Os tempos de viagem encontrados, inseridos na tabela de atributos do arquivo dos pontos de controle, seriam utilizados para a construção subsequente de quatro matrizes de distância, uma para cada sede. Para isto, lançou-se mão do procedimento de interpolação, optando-se, em meio as inúmeras possibilidades existentes no ArcGIS 9.3, pela utilização do método de interpolação denominado "vizinho natural", caracterizado pela não extrapolação do conjunto de dados e pelo cálculo dos valores mediante a média ponderada dos pontos vizinhos. Os produtos finais seriam quatro arquivos em formato raster, dentro dos quais cada unidade mínima (pixel) apresentaria um determinado valor associado ao tempo de deslocamento para cada cidade.

A etapa subsequente esteve centrada na comparação entre as quatro matrizes de distância, mediante procedimentos de álgebra de mapas, para a identificação da linha de equivalência entre ambas. Adotando-se matriz de A como referência, procedeu-se a sobreposição dos quatro arquivos, aliada ao emprego de 
uma função matemática para a classificação dos pixels da referida matriz em maiores, iguais ou menores aqueles existentes nas demais, considerando para isso os valores de deslocamento presentes em cada um. No ArcGIS 9.3, a inserção da expressão "[Matriz_A.tif] $<=$ [Matriz_B.tif] \& [Matriz_A.tif] $<=$ [Matriz_C.tif] \& [Matriz_A.tif] <= [Matriz_D.tif]" na ferramenta "Raster Calculator" produziu uma nova matriz, composta por pixels binários, dentro da qual os valores 0 e 1 representam, respectivamente, resultados falsos e verdadeiros para a equação utilizada. $O$ procedimento seria repetido para B, C e D.

A subsequente conversão das novas matrizes em arquivos vetoriais (somente a área com valores iguais a 1 para cada uma), posteriormente agrupados em um arquivo único, produziria assim a repartição da área de estudo em quatro "territórios brutos". Por fim, a geração da malha de coordenadas de 30 segundos de lado ${ }^{29}$, o cálculo das áreas de interface e a adaptação dos limites brutos para a obtenção dos limites finais seriam as etapas contempladas de forma subsequente.

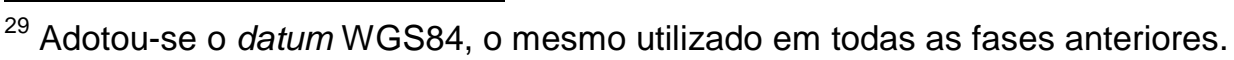

